UNIVERSIDADE DE SÃO PAULO

FACULDADE DE FILOSOFIA, LETRAS E CIÊNCIAS HUMANAS

DEPARTAMENTO DE FILOSOFIA

\title{
Entre o Ser e o Nada: a dissolução ontológica na filosofia de Merleau-Ponty
}

Alex de Campos Moura

\begin{abstract}
Tese apresentada ao Programa de Pós Graduação do Departamento de Filosofia da Faculdade de Filosofia, Letras e Ciências Humanas da Universidade de São Paulo, para obtenção do título de Doutor em Filosofia
\end{abstract}

Orientador: Prof. Dr. Carlos Alberto Ribeiro de Moura

São Paulo

2010 
UNIVERSIDADE DE SÃO PAULO

FACULDADE DE FILOSOFIA, LETRAS E CIÊNCIAS HUMANAS

DEPARTAMENTO DE FILOSOFIA

Entre o Ser e o Nada: a dissolução ontológica

na filosofia de Merleau-Ponty

Alex de Campos Moura

São Paulo

2010 
À minha mãe 


\section{Agradecimentos}

À minha irmã

Ao meu pai e ao meu irmão

À minha Lua e à minha Canô

Aos meus amigos: Lu, Vera, Thelma, Felipe e Eric

Ao meu orientador Prof. Carlos Alberto

Ao pessoal da secretaria: Marie, Gêni, Maria Helena, Verônica, Luciana e

Roseli

À FAPESP, pelo apoio imprescindível para a realização deste trabalho. 


\title{
Resumo
}

Nossa pesquisa pretende trabalhar a maneira pela qual a filosofia de Merleau-Ponty, especialmente no que se convencionou chamar "período intermediário" e "período final" de sua obra, opera uma espécie de dissolução das dicotomias clássicas, sobretudo no que se refere à oposição entre sujeito e objeto, propondo uma reformulação ontológica que recusa a cisão entre o Ser e o Nada, buscando afirmar e explicitar a reversibilidade originária entre eles.

\section{Abstract}

Our research intends to show the way Merleau-Ponty's philosophy, especially during what is usually called its "intermediary period" and its "last period", realizes a dissolution of classical dicotomies, over all the one that concerns the oposition between subject and object, proposing an ontological reformulation that refuses the cleavage between Being and Nothingness, intending to affirm the original reversibility betwwen them.

\author{
Palavras-chave \\ Ontologia - linguagem - visão - Ser - Nada
}

\section{Key-words}

Ontology - language - vision - Being - Nothingness 


\section{Índice}

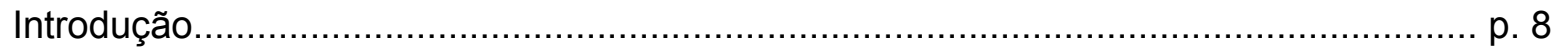

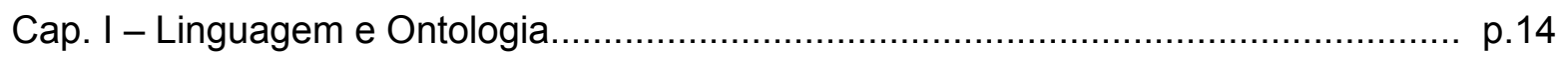

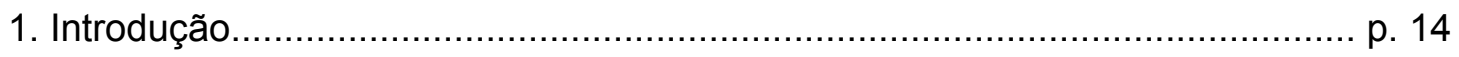

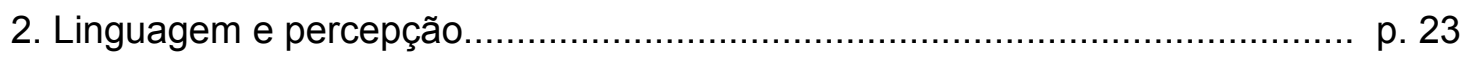

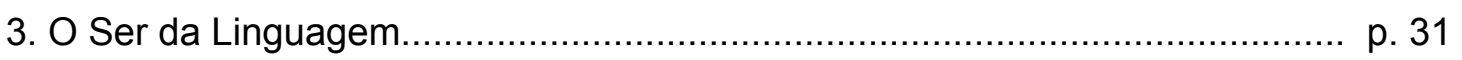

Cap. II - Linguagem e pintura: a gênese espontânea do Ser.................................... p. 64

1. Introdução......................................................................................... p. 64

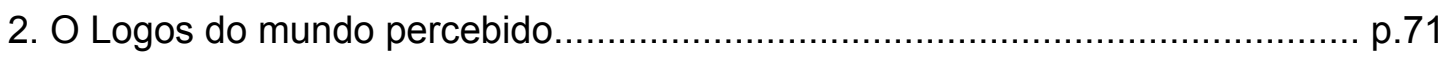

3. História, corpo e tempo.......................................................................... p. 97

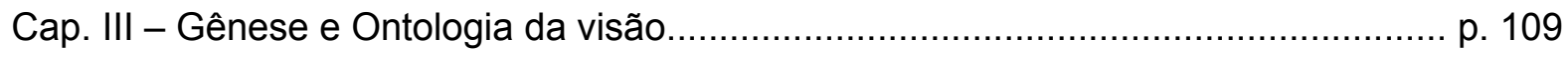

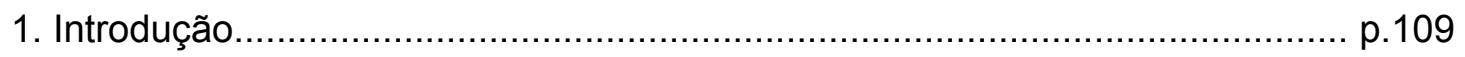

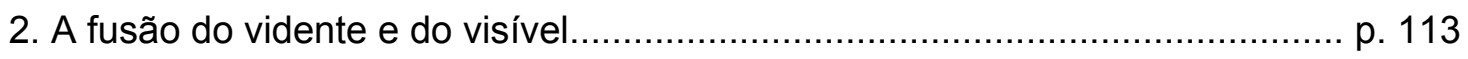

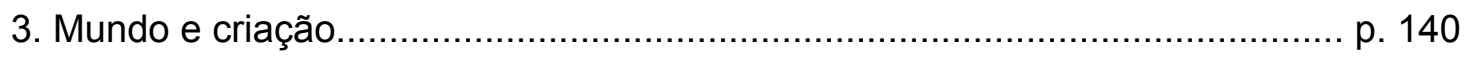

4. A cor, a linha e a gênese do sensível.................................................. p. 151 
Cap. IV - Entre o Ser e o Nada: o visível e o invisível.

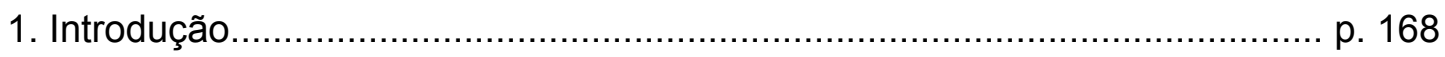

2. A crítica às filosofias do negativo......................................................... p. 181

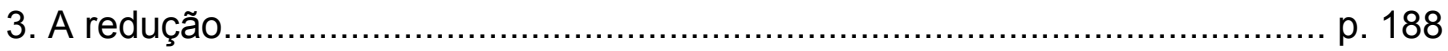

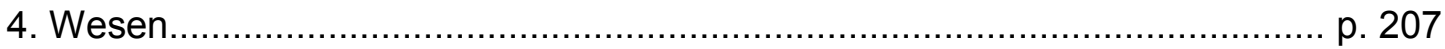

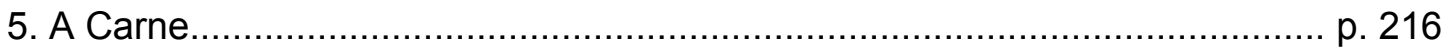

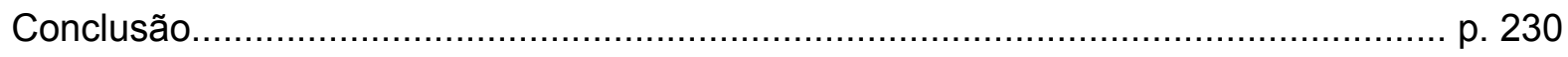

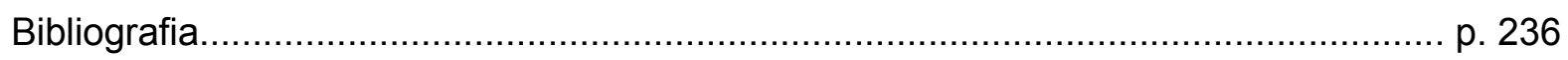




\section{Introdução}

Esta pesquisa pretende trabalhar a maneira pela qual a filosofia de MerleauPonty opera uma espécie de dissolução das dicotomias clássicas, sobretudo no que se refere à oposição entre sujeito e objeto, propondo uma reformulação ontológica que recusa a cisão entre o Ser e o Nada. Concentrando-nos naquilo que se convencionou denominar "período intermediário" e "período final" de sua obra, buscamos explicitar a presença dessa ontologia como base latente de suas descrições.

Dando continuidade a uma hipótese de trabalho circunscrita anteriormente ${ }^{1}$, e que buscava mostrar uma dimensão ontológica já no início de sua filosofia, procuramos agora indicar a permanência deste eixo ontológico no decorrer de sua reflexão, sustentando suas proposições e articulando-as sob um projeto comum, orientado pela recusa do dualismo clássico, pela afirmação da ecceidade do sentido e pela constatação de um movimento de gênese interno ao Ser que antecede a alternativa entre o naturante e o naturado, apoiado na reversibilidade originária entre o Ser e o Nada.

Conforme nossa pesquisa de Mestrado (MOURA, Alex de Campos. Liberdade e situação em MerleauPonty: uma perspectiva ontológica, São Paulo: Humanitas, 2010). 
Propondo uma perspectiva pouco considerada pelos estudos sobre MerleauPonty, buscamos explicitar essa dimensão ontológica já em sua análise sobre a linguagem, revelando-a como um tipo de Ser que se estrutura pela simultaneidade entre unidade e abertura. Gênese de uma totalidade graças à estrutura diacrítica de seus elementos parciais, ela explicita o processo espontâneo de instituição do sentido que abdica de qualquer agente externo, revelando a transição constitutiva entre o Ser e a negatividade, entre o todo e a abertura que o impede de repousar em si. Do mesmo modo, recorrendo aos estudos de Merleau-Ponty sobre a visão e sobre o visível, buscamos mostrar neles a presença dessa compreensão ontológica baseada no reconhecimento da dinâmica autoformativa do Ser, revelando-o como unidade internamente diferenciada, totalidade que irradia singularizando-se e manifestando-se sem perder seu caráter unitário. Como veremos, pondo em suspenso o dualismo clássico, o Ser latente nas descrições de Merleau-Ponty se configura como reflexividade estrutural entre o geral e o singular, transição originária entre o Ser e o Nada.

O que pretendemos sustentar, assim, é que não apenas há uma ontologia por sob as diversas decrições trabalhadas pelo filósofo, mas também que um de seus núcleos principais está na afirmação dessa reversibilidade originária entre o Ser e o Nada, reconhecimento de uma unidade primária em que ambos se constituem reciprocamente, revelando um Nada estruturante, responsável por fazer ser, e um Ser aberto, internamente diacrítico. Trata-se de acompanhar o movimento por meio do qual a ontologia merleaupontyana propõe essa espécie de intercambialidade primária, ensinando uma gênese 
espontânea do sentido e do todo que se faz pela negatividade estrutural de suas partes.

Para o tratamento dessas questões, os dois capítulos iniciais se concentram na análise dos textos de Merleau-Ponty sobre a linguagem, especialmente os ensaios de Signos e A Prosa do Mundo. O terceiro e o quarto capítulos, por sua vez, concentram-se em seus textos do "último período", com especial ênfase em O Olho e o Espírito e em 0 Visível e o Invisível.

No primeiro capítulo, buscamos explicitar o modo pelo qual o filósofo, a partir de uma certa apropriação da linguística de Saussure, compreende a linguagem, formulando-a como um tipo de unidade processual que opera por diferenciação interna, estabelecendo uma comunicação espontânea entre o signo e a significação. Procuramos mostrar que essa análise se desdobra em uma dimensão ontológica, estabelecendo uma imbricação constitutiva entre o subjetivo e o objetivo, a aquisição e a transcendência. Realizando-se como passagem espontânea da parte ao todo, do signo ao sentido, a linguagem revela uma lógica concreta que não se separa de sua existência, que recorre à ela para constituir-se; é pela própria estrutura de cada parte, tomada como entidade referencial, que a unidade se forma e que um sentido constante se afirma para o conjunto.

Essa abordagem nos permitirá tratar, simultaneamente, da relação que se estabelece entre linguagem e percepção. Como veremos, é possível reconhecer em ambas um movimento similar, organicidade intrínseca às partes responsável por garantir a consistência própria a um sentido que não provém do sujeito, que não se reduz à categoria 
do objeto. Essa questão contribuirá não apenas para a explicitação do sentido ontológico da linguagem, mas também para a tentativa de se pensar a relação entre a "primeira" e a "segunda" fases da filosofia de Merleau-Ponty.

Mantendo essa linha analítica, o segundo capítulo trata principalmente da relação entre linguagem e pintura. Retomando o argumento desenvolvido anteriormente, procura-se indicar como a aproximação entre as duas artes subentende um vínculo comum com a percepção e com o mundo percebido, revelando-as como expressões de um movimento que se faz aquém da distinção entre sujeito e objeto. Partindo da maneira pela qual Merleau-Ponty compreende as duas atividades, busca-se explicitar seus pontos de intersecção, sobretudo no reconhecimento de um tipo de significação que se configura espontaneamente pelo arranjo de suas partes, formando um sentido indireto e processual que não depende dos atos deliberados de uma consciência. Retomando a relação interna entre a parte e o todo, mostramos que nos dois casos há uma síntese ou uma unificação espontânea, instituição de uma unidade aberta. Como veremos, confirmando a gênese intrínseca ao Ser - apoiada na transição originária entre o Ser e o Nada -, a linguagem e a pintura operam por diferenciação interna da totalidade, negatividade estrutural e formativa.

Em continuidade com os capítulos anteriores, o terceiro capítulo prossegue a tentativa de explicitar a ontologia latente nas descrições do filósofo, concentrando-se então em O Olho e o Espírito. Partindo de um comentário de Merleau-Ponty sobre Descartes, procura-se acompanhar o modo pelo qual as descrições do corpo como fusão do vidente e do visível, do sensível como unidade reflexiva e do sentido como instituição, conduzem 
também ao reconhecimento dessa gênese interna ao Ser, dimensão auto-instituinte que o recurso à pintura deve tornar explícita. Retomando a discussão sobre a pintura, procuramos circunscrever o espaço que ela ocupa na filosofia de Merleau-Ponty, afastando o modelo clássico de representação, contribuindo para a compreensão e explicitação desse Ser que recusa a alternativa entre o sujeito e o objeto, revelando a existência de uma comunicação interna e recíproca entre os termos tradicionalmente opostos.

Dando prosseguimento aos demais, o quarto capítulo se concentra na descrição da ontologia presente no final da obra do filósofo. Tratando sobretudo de $O$ Visível e o Invisível, busca-se compreender a afirmação de Merleau-Ponty sobre a existência de um "há" originário, unidade aberta que se oferece espontaneamente à percepção, responsável pela "fé" em um mundo e em uma organicidade que sustentam toda experiência. Partindo da explicitação dessa estrutura primária, procuramos acompanhar o modo como ela confirma a recusa dos dualismos clássicos, apoiando a crítica do filósofo tanto às filosofias negativistas quanto às intelectualistas. Nessa direção, procuramos explicitar que o reconhecimento da evidência originária do mundo implica novamente a simultaneidade entre o Ser e o Nada. Retomando e acentuando as proposições anteriores de Merleau-Ponty, reafirma-se a reversibilidade entre ecceidade e abertura, e com ela a reconfiguração ontológica que torna o Ser e o Não-Ser reciprocamente dependentes.

Apontando para a conclusão, buscamos então retomar as linhas principais dessa ontologia descrita ao longo dos quatro capítulos, procurando destacar sobretudo a reversibilidade originária entre o Ser e o Nada, unidade diacrítica proposta por Merleau- 
Ponty, na qual os termos espontaneamente transitam e se revertem um no outro, pondo em suspenso a ontologia clássica e o positivismo de suas categorias. 


\section{Linguagem e Ontologia}

1. Introdução

"Se a volta ao Lebenswelt, e em particular a volta da linguagem objetivada à fala, é considerada absolutamente necessária, isso quer dizer que a filosofia deve refletir sobre o modo de presença do objeto ao sujeito, sobre a concepção do objeto e a concepção do sujeito tais como se mostram na revelação fenomenológica (...) Se realmente a fenomenologia não envolvesse já a nossa concepção do ser e a nossa filosofia, nos defrontaríamos novamente, ao chegar ao problema filosófico, com os mesmos problemas que suscitaram a fenomenologia."

\footnotetext{
2 MERLEAU-PONTY, Maurice. Signos, São Paulo: Martins Fontes, 1991, p. 99
} 
Neste primeiro capítulo de nosso trabalho, procuramos tratar da análise da linguagem no que se convencionou chamar o "segundo período" da filosofia de MerleauPonty. Nosso objetivo é mostrar, por um lado, que sua análise dispõe de uma dimensão ontológica, por recusar a distinção clássica entre signo e significação, objeto e sujeito; e, por outro, em consonância com o primeiro, que ela mantém-se vinculada à problemática trabalhada anteriormente pelo filósofo, nos posicionando diante da questão, tão discutida pelos comentadores, sobre uma possível ruptura que o estudo da linguagem traria no interior da obra. Essa questão nos parece relevante não só por ser tema central na maioria dos estudos sobre o autor, mas porque, a nosso ver, ela é inseparável da primeira, isto é, a discussão a respeito da compreensão de Merleau-Ponty sobre a linguagem envolve uma tentativa de circunscrever seu lugar e suas relações com os demais aspectos de sua filosofia.

De acordo com a maior parte dos comentários destinados ao assunto, a linguagem traria um tipo de cisão no interior da reflexão do filósofo, desatando os nós em que sua "primeira filosofia" teria se enredado, pela incapacidade de oferecer uma saída consistente ao modelo intelectualista. Seja pela permanência de uma "atividade categorial" que escaparia à toda condição situacional ${ }^{3}$ (Bimbenet), seja pela inconsistência da noção de intencionalidade, incapaz de articular as descrições do filósofo ${ }^{4}$ (Saint-Aubert), ou mesmo

BIMBENET, Étienne. Nature et humanité, Paris: Vrin, 2004

4 "La Phénoménologie de la perception travaille la notion d'intentionalité au fil de tentatives dont la diversite fragilise l'unité de l'ouvrage" (SAINT-AUBERT, Emmanuel de. Le scénario cartésien, França;Vrin, 2005, p. 141) 
pela falta de um embasamento propriamente filosófico para essas descrições ${ }^{5}$ (Barbaras), a "primeira" filosofia de Merleau-Ponty - especialmente aquela presente na Fenomenologia da Percepção - não teria sido suficiente para abandonar o subjetivismo característico das filosofias da consciência, não conseguindo propor, como pretendia, uma articulação efetiva entre as oposições clássicas, especialmente entre sujeito e objeto, sentido e existência. Desse modo, a análise da percepção, tema central desse período, teria como consequência conduzir a uma espécie de equívoco, relacionando apenas aparentemente termos que permaneceriam separados. A análise da linguagem traria, então, uma profunda novidade no interior de sua obra, pois ofereceria o primeiro esboço daquilo que o estudo anterior mostrara-se inapto a alcançar, começando a delinear uma relação intrínseca entre sujeito e objeto, significação e história; seria sobretudo a noção de expressão, como relação orgânica entre signo e sentido, formulada apenas a partir do estudo da linguagem, que traria o antídoto ao intelectualismo e ao subjetivismo latentes nas primeiras análises de Merleau-Ponty.

É possível, entretanto, divergir desse leitura. Por um lado, pode-se questionar se não há, em seus trabalhos iniciais, temas, questões e encaminhamentos analíticos que se manterão no decorrer da obra, perspectivas já abertas por suas primeiras pesquisas e que receberão das seguintes continuidade e embasamento, recusando, por isso mesmo, a idéia de uma ruptura completa. Em nossa pesquisa de Mestrado, tratando da Fenomenologia da Percepção, pudemos apontar para essa presença latente de elementos

BARBARAS, Renaud. De l'être du phénomène. Sur l'ontologie de Merleau-Ponty, Granoble: Millon, 1991, p. 30 
que apenas posteriormente seriam explicitados pelo filósofo, mas que já ali prefiguravam uma temática e uma perspectiva que o afastavam do intelectualismo.

Apenas como indicação, para situar a linha analítica que desenvolveremos aqui, julgamos relevante retomar o fato de que já ali pudemos explicitar a percepção como um movimento de gênese espontâneo, aquém da alternativa entre o subjetivo e o objetivo. Embora se trate apenas de uma breve síntese - cuja explicitação demandaria uma série de questões trabalhadas em nosso Mestrado e que não poderemos retomar aqui - nos parece importante indicá-la como introdução por se tratar de uma das bases que sustentam nossa hipótese sobre a presença de uma certa perspectiva ontológica que se mantém ao longo das análises de Merleau-Ponty. Além disso, essa breve retomada nos ajudará a compreender a compreensão da percepção que explicitaremos mais adiante, ao tratarmos do texto Le Monde Sensible et l'Expression, já então problematizando seu vínculo com a linguagem.

Em linhas gerais, em nosso Mestrado nossa tentativa foi mostrar como uma compreensão ontológica sustentada pela temporalidade apontava, já na Fenomenologia da Percepção, para uma imbricação efetiva entre sujeito e objeto, situação e liberdade, homem e mundo. O tempo nos oferecia uma relação interna entre o Ser e o Nada que tornava impossível concebê-los em termos de antítese, recusando a própria oposição entre o para si e o em si; ele realizava um tipo de unidade processual cujo sentido se afirmava precisamente por sua passagem e abertura internas, movimento que nem se identificava e nem rompia consigo, oferecendo o esboço de um tipo de Ser feito da constituição recíproca 
entre o Ser e o Nada: a negatividade como abertura estruturante do Ser, e o Ser como

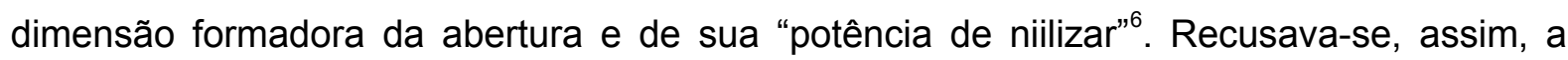
possibilidade de haver entre eles um corte preciso, que definiria a consciência como não ser puro sem qualquer relação interna com sua existência ou ser concretos, pois agora um termo passava a implicar e distender-se espontaneamente no outro: a articulação entre o Ser e o Nada inviabilizava a formulação do sujeito como uma esfera autônoma que depositaria significações puras sobre uma matéria inerte - como se a atividade sintética fosse completamente exterior a seu objeto e a formação do sentido uma afirmação da liberdade absoluta do sujeito - , apontando para a necessidade de se reconhecer um outro tipo de síntese e de formação da significação.

Assim, já na Fenomenologia da percepção, a questão do sentido e da expressão passava a ocupar um lugar privilegiado. As diversas análises do autor reencontravam sempre uma mesma necessidade de compreender a "gênese do sentido", formulando um tipo de significação que não fosse nem inteiramente subjetiva, posta por uma consciência constituinte, e nem inteiramente objetiva, um dado determinado e inequívoco. Recorrendo à percepção, Merleau-Ponty procurava propor uma relação entre sujeito e objeto distinta da clássica exterioridade entre eles, recusando a noção de síntese intelectual em nome de um tipo de "síntese passiva" que expressaria um vínculo orgânico que não os destituísse de sua ecceidade. O sujeito que percebia o sentido do que lhe aparecia no mundo não era uma consciência transcendental doadora de significação, não

6 MERLEAU-PONTY, Maurice. Fenomenologia da Percepção, São Paulo: Martins Fontes, 1996, p. 573 
era um eu absoluto que faria do mundo seu objeto de pensamento, mas um eu encarnado, que por meio de seu corpo e de sua consciência, se abria para algo que não era ele, para uma "realidade" dotada de consistência própria, com a qual permanecia organicamente atado. A constituição do sentido não dependia mais apenas de uma dimensão subjetiva, pois - graças à noção de estrutura ${ }^{7}$ e sobretudo de temporalidade ${ }^{8}-$, o filósofo encontrava uma espécie de "unidade espontânea" dos fenômenos e do percebido, uma articulação interna garantida pela própria constituição de seus elementos, entidades referenciais que faziam com que a atividade sintética deixasse de se alojar apenas no âmbito subjetivo e se estendesse a todo o mundo percebido. Essa unidade espontânea - que, como procuramos indicar ali, não era senão a unidade temporal - fornecia a Merleau-Ponty o paradigma de toda atividade expressiva, com a qual o filósofo definia não só o corpo percipiente, mas o próprio mundo percebido ${ }^{9}$. Tratava-se, em ambos os casos, de compreender uma referência espontânea de cada parte e de cada elemento ao todo, que fazia do sentido a totalidade configurada pela inter-relação de seus elementos, unidade latente, não dada em nenhuma

7 Tema central e presente em toda a obra do filósofo (Conforme, por exemplo, CHAUÍ, MARILENA. A noção de estrutura em Merleau-Ponty, in: Experiência do pensamento. Ensaios sobre a obra de Merleau-Ponty, São Paulo: Martins Fontes, 2002), a noção de estrutura envolve, desde a Estrutura do Comportamento, a contradição ou a articulação entre o para si e o em si: já ali, por exemplo, era descrita como "em-si-paramim", atada a um sujeito, mas dotada de um interior e de uma consistência próprios (MERLEAU-PONTY, La Structure du Comportement, Paris: PUF, 1990. p. 201)

8 Procuramos desenvolver esse ponto em nossa pesquisa de Mestrado (MOURA, Alex de Campos. Liberdade e situação em Merleau-Ponty: uma perspectiva ontológica, São Paulo: Humanitas, 2010) indicando que a gênese do sentido é compreendida na Fenomenologia da Percepção como uma dinâmica temporal.

9 "Essa revelação de um sentido imanente ou nascente no corpo vivo se estende, como veremos, a todo o mundo sensível, e nosso olhar, advertido pela experiência do corpo próprio, reencontrará em todos os outros 'objetos' o milagre da expressão (...) O problema do mundo, e, para começar, o do corpo próprio, consiste no fato de que tudo está ali” (MERLEAU-PONTY, Maurice. Fenomenologia da Percepção, São Paulo: Martins Fontes, 1994, p. 268 
de suas perspectivas particulares, mas visada através de sua articulação conjunta. Era essa espécie de autonomia do percebido, de seu sentido e de sua configuração, que as análises do filósofo procuravam explicitar, recusando a idéia de constituição defendida pela ontologia clássica e seu pressuposto dualista. A Fenomenologia da Percepção parecia, assim, não recair na solução unilateral do intelectalismo ou mesmo em seu oposto, o empirismo, já que fazia da contradição que ambos recusavam justamente o eixo e o tema de suas análises: "Com efeito, há contradição enquanto operamos no ser, mas a contradição cessa, ou antes ela se generaliza, une-se às condições últimas de nossa experiência, confunde-se com a possibilidade de viver e de pensar, se operamos no tempo, e se logramos compreender o tempo como a medida do ser."10

Pudemos, assim, indicar ali que a noção de expressão e de sentido como realidades portadoras de uma consistência própria, concreções de uma lógica espontânea, nem separada e nem reduzida ao sujeito, já estavam presentes, bem como as implicações ontológicas que essa noção de uma significação encarnada (ou de estrutura, como já indicava a Estrutura do Comportamento ${ }^{11}$ ) traziam, sobretudo pela implicação de uma constituição recíproca entre o para si e o em si, oferecendo o molde de um outro tipo de síntese, e com ela, de unidade e de racionalidade.

Como procuraremos apontar ao longo do capítulo, o movimento realizado pela análise merleau-pontyana da linguagem não é de todo diverso desse que sintetizamos, e poderemos ver reaparecer aqui um mesmo tipo de síntese espontânea operando na

10 MERLEAU-PONTY, Maurice. Fenomenologia da Percepção, São Paulo: Martins Fontes, 1994, p. 443

11 Conforme indicamos acima, sobre a noção de estrutura como "em-si-para-mim". 
linguagem, um movimento unitário que garante a passagem interna e constitutiva entre signo e sentido, respondendo por uma consistência própria à significação e por uma organicidade própria aos signos que põem em questão as categorias ontológicas clássicas, escapando à dicotomia entre o subjetivo e o objetivo, gênese espontânea e unidade autoformativa. Assim, poderemos sugerir que, na própria análise da linguagem - ou seja, em seu "período intermediário" - Merleau-Ponty recorre ainda à percepção e ao mundo percebido para reconhecer uma mesma matriz formativa, um mesmo processo expressivo baseado na reversibilidade estrutural dos termos. Desdobrando um eixo comum, é possível então articular as duas questões principais deste primeiro capítulo: mostrar que a análise da linguagem implica uma revisão das noções tradicionais de sujeito e objeto, explicitando uma dimensão ontológica que busca na articulação entre o Ser e o Nada o meio de conceber uma relação não opositiva e não identitária entre signo e significação já equivale ${ }^{12}$, de certo modo, a mostrar que a compreensão merleau-pontyana sobre a linguagem desdobra e embasa certos caminhos abertos por seu estudo da percepção.

Isso posto, tomando como eixo a descrição da linguagem enquanto articulação espontânea entre signo e sentido, trabalharemos em dois planos interdependentes, indicando, por um lado, as implicações dessa descrição na reconfiguração das noções de sujeito e objeto - e, com elas, do Ser e do Nada - e, por outro, o modo pelo qual ela recorre ainda à percepção e à síntese espontânea dos elementos.

12 Bem entendido, tal equivalência depende do modo como sua "primeira fase" é compreendida, e por isso iniciamos nosso trabalho situando de que lugar parte nossa leitura. 


\section{Linguagem e percepção}

Uma breve descrição dessa relação entre as duas temáticas pode ser encontrada, por exemplo, no início do curso Le Monde Sensible et l'Expression ministrado por Merleau-Ponty no Collége de France. Neste curso, proferido entre os anos de 1952 e 1953, ele tematiza precisamente a relação entre expressão e mundo percebido, acabando por encontrar neste o paradigma de todo ato expressivo: "A expressão propriamente dita, tal qual obtida pela linguagem, retoma e amplia uma outra expressão que se revela na 'arqueologia' do mundo percebido"13

É na percepção, afirma ali Merleau-Ponty, que podemos encontrar uma relação com o Ser diante da qual a tradicional compreensão da consciência como puro poder de significação e do ser como objeto posto se mostra insuficiente, apontando para a presença de um sentido que se oferece aquém da oposição entre sujeito e objeto, espécie de deformação espontânea e não explícita de nossa experiência que põe em questão as

13 MERLEAU-PONTY, Maurice. Résumés de Cours. Collège de France 1952-1960, Paris: Gallimard, 1968, p. 13: “L'expression proprement dite, telle que l'obtient le langage, reprend et amplifie une outre expression que se dévoile à l' 'archéologie' du monde perçu.” [tradução nossa] 
categorias do entendimento clássico: "Nós propusemos mostrar, ao contrário, que a filosofia aprende a conhecer, no contanto com a percepção, uma relação com o ser que torna necessário e que torna possível uma nova análise do entendimento. Porque o sentido de uma coisa percebida (...) não é dado senão como uma deformação, mas sistemática, de nosso universo de experiência, sem que nós possamos ainda the nomear o princípio." ${ }^{14}$ Reafirmando sua dimensão ontológica, o sentido do percebido ${ }^{15}$, na medida em que não se oferece de modo objetivo, mas envolve uma relação existencial, uma abertura e uma retomada por parte daquele que o compreende, recusa a compreensão da significação como uma atividade exclusivamente subjetiva, ensinando ao contrário a referência espontânea ou, mais precisamente, "a organização mesma dos fenômenos e de sua lógica interna"16 $^{16}$. Enquanto deformação, ele necessariamente remete a uma experiência adquirida e a horizontes que o atam ao passado e à generalidade, impedindo-o de ser uma absoluta criação; ao mesmo tempo, enquanto movimento sistemático e não explícito, ele dá testemunho de uma organicidade própria aos fenômenos, um tipo de compossibilidade orgânica própria ao percebido. Como já indicavam as obras anteriores do filósofo ${ }^{17}$, há na

14 MERLEAU-PONTY, Maurice. Résumés de Cours. Collège de France 1952-1960, Paris: Gallimard, 1968, p. 11,12: "Nous nous sommes proposé de montrer au contraire que le philosophie apprend a connaitre, au contact de la percecption, un rapport avec l'être qui rend nécessaire et qui rend possible une nouvelle analyse de l'entendement. Car le sens d'une chose perçue (...) n'est donne que comme une deformation, mais systématique, de notre univers d'éxperience, sans que nous puission encore en nommer le principe" [tradução nossa]

15 A questão do sentido do percebido é um dos principais temas desenvolvidos na "primeira filosofia" de Merleau-Ponty.

16 MERLEAU-PONTY, Maurice. Résumés de Cours. Collège de France 1952-1960, Paris: Gallimard, 1968, p. 15: "l'agencement même des phénomènes et de leur logique interne" [tradução nossa]

17 Conforme procuramos indicar em nossa pesquisa de Mestrado (MOURA, Alex de Campos. Liberdade e situação em Merleau-Ponty: uma perspectiva ontológica, São Paulo: Humanitas, 2010). 
percepção, e no movimento que Ihe corresponde, uma implicação espontânea, uma estruturação ou uma referência constitutiva das partes, que faz com que toda síntese perceptiva implique já a "presença total do mundo"18, que cada elemento só se ofereça à percepção trazendo consigo os demais enquanto horizontes, esboçando uma totalidade diante da qual ele não é senão uma certa referência. É por isso que toda atividade perceptiva envolve uma dimensão situacional e passiva, pois toda percepção envolve espontaneamente uma abertura e um fundo não explícito por meios dos quais o percebido se forma como unidade intencional: a percepção só se realiza sendo simultaneamente “(...) impercepção de um horizonte ou de um fundo, que ela implica, mas não tematiza” ${ }^{\text {, }}$, revelando uma consciência “(...) indireta ou mesmo inversa em relação a um ideal de adequação que ela presume, mas não vê face à face."20

Assim compreendida, a significação deixa de ser um objeto designável para revelar-se envolvida em um todo mais amplo, em uma sistematicidade que a engloba e a impede de ser tomada por si, reafirmando o mundo como unidade latente e pressuposta em cada ato perceptivo, "campo aberto" implicando uma consciência ela própria lacunar e indireta, incapaz de apreender a totalidade de um objeto que não se oferece senão por horizontes implícitos que o remetem para fora de si; ao mesmo tempo, porém, justamente por essa abertura que o faz escapar à esfera de uma subjetividade constituinte, o mundo

18 MERLEAU-PONTY, Maurice. Résumés de Cours. Collège de France 1952-1960, Paris: Gallimard, 1968, p. 15

19 MERLEAU-PONTY, Maurice. Résumés de Cours. Collège de France 1952-1960, Paris: Gallimard, 1968, p. 12: “(...) imperception d'un horizon ou d'un fond, qu'elle implique, mais ne thématise pas.” [tradução nossa] 20 MERLEAU-PONTY, Maurice. Résumés de Cours. Collège de France 1952-1960, Paris: Gallimard, 1968, p. 12: “(...) indirecte ou même invéerse par rapport à un idéal d'adéquation qu'elle présume, mais qu'elle ne regarde pas en face.” [tradução nossa] 
preserva a possibilidade da ação e de um desdobramento consciente: "Se o mundo percebido é assim compreendido como um campo aberto, seria tão absurdo lhe reduzir todo o resto quanto lhe supor um 'universo de ideias' que nada lhe deveriam. Há de fato reversão quando se passa, do mundo sensível onde estamos presos, a um mundo de expressão onde buscamos captar e tornar disponíveis as significações, mas esta reversão e o 'movimento retrógrado' da verdade são chamados por uma antecipação perceptiva.." ${ }^{21}$ Entre o mundo percebido e o mundo da expressão não se estabelece, portanto, nem uma relação de identidade e nem de cisão; ao contrário, como procuraremos mostrar, a inversão implicada pela passagem para o mundo da cultura é chamada pela própria dinâmica perceptiva e como que antecipada por ela, sem contudo haver determinismo ou redução de um ao outro, e sim, como veremos, uma troca e uma influência recíprocas. O que os articula não é, pois, uma relação de causalidade, mas a constatação de que de um ao outro não há uma alteração substancial ${ }^{22}$, não há propriamente sequer uma mudança de mundo ${ }^{23}$, pois em ambos o que opera é uma mesma articulação espontânea dos fenômenos ou dos fatos, uma mesma passagem interna do signo ao sentido que faz com que a expressão deixe de ser uma atividade exclusiva do sujeito e se desdobre também no objeto, recusando a separação completa entre eles:

${ }^{21}$ MERLEAU-PONTY, Maurice. Résumés de Cours. Collège de France 1952-1960, Paris: Gallimard, 1968, p. 12: "Si le monde perçu est ainsi compris comme un champ ouvert, il serait aussi absurde d'y réduire tout le reste que de lui superposer un 'univer des idées' quin ne lui dût rien. Il y a bien renversement quand on passe, du monde sensible où nous sommes pris, à un monde de l'expression où nous cherchons à capter et rendre disponibles les significations, mais ce renversement et le 'mouvement rétrograde' du vrai sont appelés par une antecipation perceptive." [tradução nossa]

22 Esse ponto será mais explicitado quando tratarmos da relação entre obra e criação.

23 MERLEAU-PONTY, Maurice. A linguagem indireta e as vozes do silêncio, in: Signos, São Paulo: Martins Fontes, 1992 
“(...) se dois pontos imóveis sucessivamente projetados sobre uma tela são vistos como dois traços de um só movimento, no qual perdem mesmo toda existência distinta, é que aqui as influências externas vêm se inscrever em um sistema de equivalências prestes a funcionar e operar sobre nós, assim como os signos da linguagem, não Ihes dispertando as significações que lhes correspondem ponto por ponto, mas como marcas de um só processo em via de desenvolvimento, como discriminantes de um sentido que, por assim dizer, os anima à distância. A percepção é então já expressão, mas esta linguagem natural não isola, não faz 'sair' o exprimido, que permanece aderente à "cadeia perceptiva" mais e diversamente do que à cadeia verbal." ${ }^{24}$

Assim, entre a percepção e a linguagem não pode haver propriamente ruptura no que se refere à questão do sentido e da expressão: o percebido se revela ele mesmo expressivo, e a linguagem retoma a mesma unidade espontânea revelada pela percepção. Nos dois casos - como poderemos mostrar mais claramente ao trabalharmos especificamente a linguagem - trata-se de um sentido que não se oferece senão de modo lateral ou indireto, inseparável da configuração concreta em que se manifesta e à qual permanece ligado; do mesmo modo, os signos que o manifestam aparecem como entidades referenciais e não positivas, já que apenas por sua relação com o todo se tornam

24 MERLEAU-PONTY, Maurice. Résumés de Cours. Collège de France 1952-1960, Paris: Gallimard, 1968, p. 13: “(...) si deux points imobiles successivement projetes sur un écran sont vus comme deux traces d'un seul mouvement, dans lequel elles perdent même tout existence distincte, c'est qu'ici les influences externes viennent s'inscrire dans un système d'équivalences prêt à fonctionner et opèrent sur nous, à la façon des signes du langage, non pas en éveillant des significations qui leur correspondent point par point, mais comme jalons d'un seul processus en cours de déroulement, comme discriminants d'un sens qui, pour ainsi dire, les anime à distance. La perception est donc deja expression, mais ce langage naturel n'isole pas, ne fait pas 'sortir' l'exprimé qui reste adhérent à la 'chaine perceptive' autrement et plus qu'à la chaine verbale." [tradução nossa] 
significativos. É enquanto auto-referência espontânea dos fenômenos ou dos signos que esse sentido se constitui, adquirindo uma consistência ou uma "alteridade" que o sujeito retoma, mas não engendra. Tal como já ocorria desde a Estrutura do Comportamento, com a noção de estrutura, trata-se de uma significação encarnada, cuja ecceidade reside em seus horizontes internos e espontâneos, referenciais constitutivos que a atam ao todo (o mundo ou a linguagem) fazendo-a escapar à pura subjetividade. Em ambos os casos, esse sentido, ao fazer com que toda percepção e toda expressão sejam dependentes da totalidade do linguagem ou do mundo ${ }^{25}$ que as circunscrevem, revela uma subjetividade não posicional aberta a uma significação que se oferece como realidade: "É 'sobre o objeto' (J. Pauliard) e finalmente na presença total do mundo que se faz a síntese perceptiva, é na, é pela 'implicação' que a luz natural da percepção se abre um caminho."26

Assim, como procuraremos explicitar ao longo do capítulo, o movimento expressivo que se cristaliza na linguagem encontra-se presente já na percepção, assim como o Logos ou a racionalidade espontâneos do mundo percebido reverberam na articulação interna à linguagem; o que torna possível sustentar que é a expressão, enquanto movimento (ou racionalidade) espontâneo, que ata "natureza" e "cultura", não por manter-se idêntica em ambas, mas ao contrário por realizar-se como passagem orgânica e constitutiva entre a ordem dos fatos e a das significações, entre o percebido e o sentido,

25 MERLEAU-PONTY, Maurice. Résumés de Cours. Collège de France 1952-1960, Paris: Gallimard, 1968, p. 14

26 MERLEAU-PONTY, Maurice. Résumés de Cours. Collège de France 1952-1960, Paris: Gallimard, 1968, p. 14: “C'est 'sur l'objet' (J.Pauliard) et finalment dans la presence totale du monde que se fait la synthèse perceptive, c'est dans, c'est par l' "implication" que la lumiére naturelle de la perception s'ouvre um chemin." [tradução nossa] 
acabando por pôr em suspenso a própria cisão entre eles. Como afirma Merleau-Ponty ao término de seu curso, o estudo da linguagem é ainda um meio de pensar a relação entre o "mundo natural" e o "mundo cultural"; uma tentativa - assim como havia sido seu estudo da percepção - de encontrar entre eles um terreno comum aquém da alternativa clássica entre o objetivo e o subjetivo: "Estudando o simbolismo linguístico, considerando não apenas um mundo expressivo mas também um mundo falante, nós nos colocamos em situação de fixar definitivamente o sentido filosófico das análises precedentes, quer dizer a relação da expressão 'natural' e da expressão da cultura. Poderemos então decidir se a dialética da expressão significa que um espírito está já presente na natureza ou que a natureza é imanente a nosso espírito, ou mais ainda buscar uma terceira filosofia além desse dilema." ${ }^{27}$ Longe de trazer um tema inteiramente novo à filosofia de Merleau-Ponty, o estudo da linguagem parece enfim reencontrar um projeto mais amplo, na tentativa de "aprofundar e fixar definitivamente o sentido filosófico" ${ }^{28}$ daquilo que já se apresentara em seus estudos anteriores, reencontrando a mesma "contradição" existencial ou ontológica que sua análise da percepção havia revelado, buscando apontar a impossibilidade de se manter a cisão completa entre o subjetivo e o objetivo, explicitando a ecceidade do sentido e a gênese espontânea própria ao Ser.

27 MERLEAU-PONTY, Maurice. Résumés de Cours. Collège de France 1952-1960, Paris: Gallimard, 1968, p. 20, 21: "En étudiant le symbolisme linguistique, en considérant non seulement un monde expressif mais encore un monde parlant, nous nous mettrons en mesure de fixer définitivement le sens philosophique des analyses précédents, c-est-à-dire le rapport de l'expression 'naturelle' et de l'expression de culture. On pourra alors decider si la dialectique de l'expression signifie qu'un esprit est déjà présent dans la nature ou que la nature est immanente à notre esprit, ou plutôt chercher une troisième philosophie au-delà de ce dilemme." [tradução nossa]

28 MERLEAU-PONTY, Maurice. Parcours II, Verdier, 2000, p. 41 
Para podermos desdobrar essa significação ontológica e essa proximidade temática que sugerimos, cabe agora examinar de modo mais detido a maneira pela qual a operação expressiva se realiza no campo da linguagem, articulando internamente signo e significado, recusando-os como entidades positivas e opostas que se comporiam por um termo exterior. 
3. O Ser da Linguagem

"O que me é ensinado pela fenomenologia da linguagem (...) é uma nova concepção do ser da linguagem, que é agora lógica na contingência, sistema orientado, e que entretanto elabora sempre os acasos, prosseguimento do fortuito na totalidade que tem um sentido, lógica encarnada."29

Em seu ensaio Sobre a Linguagem Indireta e as Vozes do Silêncio, que trata explicitamente da questão da linguagem, é possível reconhecer a mesma perspectiva indicada acima balizar o estudo de Merleau-Ponty, na tentativa de mostrar que a linguagem não se reduz nem a um objeto ideal do pensamento - como pretendia Husserl no início de sua carreira, quando defendia a possibilidade de uma eidética da linguagem que daria acesso a uma gramática universal ${ }^{30}$ - e nem a uma soma de acasos, revelando-se como

29 MERLEAU-PONTY, Maurice. Signos, São Paulo: Martins Fontes, 1991, p. 93

$30 \quad$ Idem, p. 89 
movimento único e espontâneo por meio do qual a contingência se faz significação, o sentido se torna existência. Como antecipa o trecho citado acima, há na análise merleaupontyana da linguagem um projeto implícito, que procuraremos aqui compreender: a tentativa de desvelar um tipo de Ser em que lógica e contingência, unidade e diversidade, encontram-se constitutivamente ligados, fazendo do subjetivo e do objetivo momentos reversíveis em uma totalidade comum. Assim formulado, esse projeto reata com uma perspectiva que desde a Estrutura do Comportamento norteia as pesquisas do filósofo: como indicamos acima, o esforço de circunscrever e explicitar a "contradição" ontológica entre o ser para si e o ser em si, entre a atividade singular e a generalidade situacional. Ajudando-nos a sustentar nossa hipótese de trabalho, tal como ocorria em suas obras iniciais, também aqui veremos que a noção do sentido como existência concreta e autoconsistente revela-se central, oferecendo-se como fusão entre esses dois planos, lógica encarnada que, por sua própria estrutura, recusa o positivismo e escapa às categorias ontológicas clássicas.

É sob esse projeto analítico que parece se justificar o modo pelo qual Merleau-Ponty recorrerá à linguística de Saussure, ao mesmo tempo assumindo e contestando as posições do autor. Recusando a positividade científica e o tratamento unilateral da linguagem, sua discussão com a línguistica revela-se embasada em uma questão mais geral, referente à ontologia latente implicada no modo pelo qual se compreende a linguagem: "Podemos simplesmente justapor as duas perspectivas que acabamos de distinguir - a linguagem como objeto de pensamento e a linguagem como 
minha? Era isso que fazia Saussure, por exemplo, quando distinguia uma linguística sincrônica da fala e uma linguística diacrônica da língua, irredutíveis uma à outra porque uma visão pancrônica inevitavelmente apagaria a originalidade do presente (...) Então a experiência da fala nada teria para nos ensinar sobre o ser da linguagem, não teria alcance ontológico."31 Recusando a ausência de significação ontológica no estudo da linguagem ausência que é, na verdade, a afirmação implícita de uma ontologia sempre pressuposta pela ciência $^{32}$ - Merleau-Ponty concentra sua análise precisamente naquilo que a perspectiva científica ignora ou nega, a articulação entre sincronia e diacronia, a linguagem como sentido e a linguagem como objeto, procurando explicitar seus desdobramentos no campo da ontologia. Em um movimento recorrente em sua obra, o filósofo parte do interior do campo da objetividade para buscar o que nele resiste e ultrapassa suas próprias premissas; assim, recorre a Saussure ao mesmo tempo que procura o que, nele, contesta e questiona seus enunciados internos.

Não se trata portanto, como mostra Moutinho ${ }^{33}$, de uma leitura inteiramente fiel à sua fonte, pois ao contrário do que ocorre com o linguista, para quem os dois planos permanecem distintos e independentes entre $\mathrm{si}^{34}$, a análise de Merleau-Ponty trata justamente da articulação entre o campo da diacronia e o da sincronia. Segundo ele, ainda que Saussure não tenha propriamente formulado essa articulação, é seu “(...) o imenso

31 MERLEAU-PONTY, Maurice. Signos, São Paulo: Martins Fontes, 1991, p. 91

32 Já a Fenomenologia da Percepção mostrava que a ciência opera com pressupostos ontológicos. Conforme nossa pesquisa de Mestrado (MOURA, Alex de Campos. Liberdade e situação em Merleau-Ponty: uma perspectiva ontológica, São Paulo: Humanitas, 2010).

33 MOUTINHO, Luiz Damon Santos. Razão e Experiência - ensaio sobre Merleau-Ponty, Rio de Janeiro, UNESP, 2006

34 Para o tratamento detalhado dessa questão, podemos indicar o trabalho de MOUTINHO citado acima. 
mérito de dar o passo que liberta a história do historicismo e torna possível uma nova concepção da razão"35 - movimentos centrais aos olhos do filósofo, que, como procuraremos indicar, são precisamente os que sua análise busca desdobrar - pois ele inaugura "(...) ao lado da linguística da língua, que a faria ser vista, no limite, como um caos de acontecimentos, uma linguística da fala, que deve mostrar em si, a cada momento, uma ordem, um sistema, uma totalidade sem os quais a comunicação e a comunidade linguística seriam impossíveis" ${ }^{36}$, deixando entrever uma articulação e uma coerência próprias à linguagem que a impedem de ser apreendida por uma história objetiva: mesmo que ao longo de suas diferentes fases históricas, os termos de uma língua recebam uma série de significações discordantes, cada um de seus momentos permanece coeso e expressivo, impossibilitando que ela seja decomposta objetivamente e reduzida a uma soma de $\operatorname{acasos}^{37}$.

Contra a recíproca exclusão entre o domínio sincrônico da significação e o domínio diacrônico da objetividade, a "linguística da fala" aponta para uma espécie de sincronicidade interior à linguagem, própria aos seus elementos tomados conjuntamente, apontando para a imbricação entre o subjetivo e o objetivo: "Em primeiro lugar, o ponto de vista 'subjetivo' envolve o 'objetivo'; a sincronia envolve a diacronia. O passado da linguagem começou por estar presente, a série de fatos fortuitos que a perspectiva objetiva evidencia incorporou-se numa linguagem que, a cada momento, era um sistema dotado de

\footnotetext{
MERLEAU-PONTY, Maurice. A prosa do mundo, São Paulo: Cosac \& Naify, 2002, p. 45

36 Idem, p. 45

37 Idem, p. 45, 46
} 
uma lógica interior. Se a linguagem portanto, considerada num corte transversal, é sistema, também é preciso que o seja em seu desenvolvimento" ${ }^{38}$. Já apontando para a base temporal da articulação pretendida, Merleau-Ponty indica que os fatos linguísticos, enquanto presentes, necessariamente se inserem em um sistema dotado de uma "lógica interna", se compõem e se organizam segundo uma unidade intrínseca, o que torna impossível tratá-los como entidades objetivas isoláveis, bem como considerar a passagem de um ao outro como o resultado do acaso ou de uma atividade exterior - como veremos abaixo, é por sua própria constituição que cada elemento passa nos outros, afirmando com eles uma totalidade espontânea. Por outro lado, o sistema assim formado não pode mais adequar-se à categoria de uma significação pura e absoluta, revelando-se portador de fissuras por onde a facticidade, e com ela a contingência, podem inserir-se ${ }^{39}$. A tarefa implícita deixada então pela linguística ${ }^{40}$ passa a ser encontrar, no próprio devir da linguagem, em seu movimento concreto e histórico, a gênese de um sentido ele próprio contingente e aberto, inseparável de sua existência no tempo.

Recorrendo ao exemplo da língua francesa em sua relação com o latim ${ }^{41}$, Merleau-Ponty mostra que, por um lado, as modificações que ocorrem no interior de uma língua, o desaparecimento de uma forma e sua substituição por outra por exemplo, não ocorrem de maneira abrupta ou imotivada, como se resultassem da fatalidade; ao contrário, elas se dão de modo gradual, obedecem a um princípio latente e a uma demanda interna da

38 MERLEAU-PONTY, Maurice. Sobre a fenomenologia da linguagem, in: Signos, São Paulo: Martins Fontes, 1991, p. 92

39 Idem, p. 92

40 Idem, p.92

41 MERLEAU-PONTY, Maurice. A prosa do mundo, São Paulo: Cosac \& Naify, 2002, p. 56 
própria língua, enquanto essa procura preservar seu poder expressivo. Se o sentido se forma na facticidade, ele precisa dela para manter-se, e longe de uma ruptura, o que os fatos e as mudanças concretas de uma língua devem oferecer é o meio pelo qual ela pode preservar-se, reafirmando sua unidade e seu sentido através do movimento que transforma esses acasos em sistema, que incorpora a contingência em uma articulação mais ampla: "Temos de encontrar um sentido no próprio devir da linguagem, concebê-la como um equilíbrio em movimento (...) É assim que se forma um novo meio de expressão e que uma lógica obstinada vence os efeitos de desgaste e a própria volubilidade da língua” ${ }^{42}$. Assim, se a lógica "vence" a volubilidade da língua, e a expressão se realiza - se "há sentido"43 — , é preciso que ao invés de opor-se à ela, essa lógica se una à contingência para torná-la expressiva, assumindo as mudanças em um movimento que não cessa diante da facticidade, mas se serve dela para manifestar-se, fazendo do dado sistema e do acaso significação; mais ainda, como veremos, se ela pode inserir-se desse modo no domínio dos fatos, é por ser intrínseca a esse domínio, isto é, são as próprias mudanças que configuram e sustentam essa lógica encarnada, compondo entre si um todo harmônico que revela a “astúcia” própria ao movimento expressivo.

A diacronia começa a deixar de opor-se à sincronia porque a "linguística da fala" permite reconhecer que não há um terceiro termo que, do exterior, as comporia, e sim uma relação interna entre elas, constatação de que é pela própria estruturação dos fatos

42 MERLEAU-PONTY, Maurice. Sobre a fenomenologia da linguagem, in: Signos, São Paulo: Martins Fontes, 1991, p. 92

43 Como procuraremos indicar ao longo desse trabalho, a afirmação da existência própria e espontânea do sentido é um dos pontos centrais da filosofia de Merleau-Ponty, configurando uma das questões que permite reconhecer a continuidade de suas pesquisas. Retornarmos a esse tema. 
que se forma sua sincronicidade. Ainda conforme o exemplo da língua francesa, se a linguagem é capaz de comunicar e de significar, é porque a eficácia do sistema expressivo provém de sua capacidade de transformar o devir em sentido, e não por permanecer atada a uma significação inequívoca que se manteria ausente de toda facticidade. Sem mudanças, sem a abertura que a torna processual, a linguagem se tornaria prisioneira de um sentido imutável, pereceria quando este caísse em desuso, incapaz de comunicar e de responder às demandas sempre renováveis do presente e da comunicação: o que permite à língua se conservar como força de expressão e de significação, capaz de concentrar seus diferentes elementos em um sentido comunicável, são justamente as mudanças históricas pelas quais ela passa, pois aqui a unidade do conjunto não é a identidade estática do objeto, mas a "coerência interna" de um processo que não se separa e nem se identifica a si, estilo ou princípio constante de seu movimento de diferenciação ${ }^{44}$.

E é ainda ao próprio Saussure que Merleau-Ponty recorre para indicar como se estrutura essa constituição recíproca entre sincronia e diacronia, buscando o que nele permite compreender a passagem do signo à significação como movimento espontâneo e interno à linguagem, atando a multiplicidade de manifestações concretas à unidade de um sentido comum que elas expressam. Seu ponto de partida - como de costume tomado a partir do pensamento objetivo - é mostrar que ao conceber o signo como elemento referencial e diacrítico, isto é, ao mostrar que ele isoladamente nada significa, que não possui um sentido próprio designável e que ele “(...) significa apenas sua diferença com

${ }^{44}$ Central na ontologia de Merleau-Ponty, a compreensão de uma unidade que se estrutura por meio de sua dinâmica auto-diferencial será explicitada e trabalhada ao longo de toda a Tese. 
relação aos outros" ${ }^{\text {, }}$, a linguística saussuriana descobre uma comunicação interna e constitutiva entre signo e sentido. Uma vez compreendido que o signo não é o invólucro vazio de uma idéia que existiria por si e para si - pois é apenas sua relação com os demais que o torna significativo e capaz de referir-se ao sentido -, e que correlativamente ele não dispõe de uma existência positiva e autônoma - pois depende da totalidade para se constituir em significação - torna-se impossível estabelecer uma exterioridade completa entre seu campo e aquele das significações: o sentido depende do movimento espontâneo dos signos para formar-se, e estes dependem da unidade desse mesmo movimento para se constituírem em sentido. Conceber o signo como entidade referencial implica dizer que ele, por sua própria constituição, remete e forma um conjunto ou um sistema, que ele não é senão uma certa referência aos demais e, no limite, ao todo, e que cada signo só se realiza através de horizontes que o fazem necessariamente atado à totalidade da língua; espontaneamente ele se articula aos demais e a um sentido que lhes é próprio. A significação não provém do exterior, de uma consciência que a depositaria nos signos, mas se forma neles próprios, pela abertura e pela estrutura que os constitui como sistema e unidade. Desse modo, tomar o signo como essencialmente diacrítico implica reconhecer, de um lado, um tipo de atividade que Ihe é própria, uma organicidade ou uma lógica espontâneas que o impedem de ser tratado como simples designação, e, por outro, uma espécie de encarnação do sentido, não mais um puro pensamento, mas inseparável de sua configuração concreta. Equivale, assim, a recusar a positividade de ambos, já que o que

45 MERLEAU-PONTY, Maurice. Sobre a fenomenologia da linguagem, in: Signos, São Paulo: Martins Fontes, 1991, p. 94 
constitui o signo é sua abertura aos outros, sua não coincidência ou não identidade, assim como o que constitui o sentido é essa unidade aberta e processual, essa referência espontânea entre as partes.

Assim como ocorria com a percepção, em que um fenômeno estruturalmente remetia aos demais para constituírem juntos uma unidade sem a qual nenhum deles dispunha de significação, assim como todo ato perceptivo distendia-se em horizontes abertos espontaneamente formados no mundo, também a linguagem revela-se portadora dessa espécie de "interioridade", dessa consistência própria que faz com que seu sentido dependa de um movimento que lhe é intrínseco, de uma organização e de uma lógica que não Ihe vêm do exterior, configurando seu modo de ser próprio: a linguagem, dirá MerleauPonty, não é senão um poder de diferenciação ${ }^{46}$, um modo constante e regulado de trabalhar a relação entre os signos, eles próprios entidades diacríticas - a noção de diferença é central na análise de Merleau-Ponty, pois, como veremos ao longo da Tese, ela possibilita a compreensão de uma unidade que não exclui a mudança, que se faz nela, e que recusa com isso a oposição entre identidade e alteridade puras: "A intuição de Saussure se precisa: com as primeiras oposições fonêmicas a criança inicia-se na ligação lateral do signo com o signo como fundamento de uma relação final do signo com o sentido (...) É porque é de imediato diacrítico, é porque se compõe e se organiza consigo mesmo, que ele tem um interior e acaba por reclamar um sentido" ${ }^{47}$. O sentido emerge no todo da

46 MERLEAU-PONTY, Maurice. A prosa do mundo, São Paulo: Cosac \& Naify, 2002, p. 54, 55

47 MERLEAU-PONTY, Maurice. A linguagem indireta e as vozes do silêncio, in: Signos, São Paulo: Martins Fontes, 1992, p. 41 
língua, espontaneamente, porque cada elemento não é senão uma diferenciação em relação aos outros e, por isso mesmo, a afirmação implícita da unidade do conjunto. Tratase, como indicamos acima, de um sentido em devir, que não existe para si de modo imediato e explícito, mantendo-se inseparável do movimento unitário e temporal pelo qual os signos se compõem e se diferenciam uns dos outros; sempre lidamos com "arquiteturas de signos” cuja significação não pode ser posta à parte, já que ela não é senão “(...) a maneira pela qual aqueles se comportam um em relação ao outro, pela qual se distinguem um do outro." ${ }^{48}$

Todo sentido se oferece em um contexto de signos que o insere na história e no tempo, fazendo da idéia da verdade como posse absoluta ou identidade algo impossível; mas tratam-se ainda, insiste o filósofo, de verdades e de significações, e a linguagem como diferenciação não conduz ao relativismo, pois aqui a diferença é o que afirma e preserva a unidade do todo, garantindo a coesão estrutural e originária de seus elementos: “(...) se é a relação lateral do signo com o signo que torna ambos significantes, o sentido só aparece na intersecção e como que no intervalo das palavras. Isto nos proíbe conceber, como estamos situados, a distinção e a união da linguagem e de seu sentido" ${ }^{\prime 49}$. Nem transcendente como um pensamento puro e nem imanente como uma significação pré-determinada, o sentido não está propriamente na linguagem e nem fora dela, nem inteiramente presente e nem inteiramente ausente do signo, oferecendo-se como essa espécie de diferenciação interna da totalidade. Por um mesmo movimento, ele se une e se distingue dos signos: se une, pois

\footnotetext{
48 Idem, p. 42

49 Idem, p. 42
} 
agora ele não é senão sua configuração concreta, sua unidade espontânea; se distingue, pois essa unidade permanece aberta e processual, não sendo dada em parte alguma e em signo algum, apenas se deixando entrever como "pólo latente" ou "vazio determinado", isto é, como uma espécie de negatividade circunscrita, ausência determinada e operante, embora não presente de modo explícito. O sentido, desse modo, deixa de se configurar positivamente, de afirmar-se como um Ser puro, inteiramente determinado e desdobrado, passível de se destacar para fora e para além da linguagem (expressão da pura negatividade do sujeito que o constitui); mas, por isso mesmo, por sua indeterminação circunscrita, ele também não pode estar contido no signo, não pode ser possuído pela linguagem, já que é justamente naquilo que nela se afirma como diferença que ele se forma - ou seja, o sentido, enquanto negação determinada ou diferença interna à linguagem, não pode ser nem um puro Ser e nem um puro Nada, pondo-se aquém da oposição ontológica clássica, como explicitaremos no decorrer da Tese. Não há entre ele e o signo, portanto, nem oposição e nem identidade, mas um único movimento de diferenciação que afirma ao mesmo tempo a singularidade de cada signo e a generalidade do sentido, a diferença e a unidade tornadas reciprocamente constitutivas, uma implicando estruturalmente a outra: se cada signo não é senão uma certa diferença em relação aos demais, e no limite, uma certa diferenciação do todo, essa espécie de afastamento interno trazida por ele, ao mesmo tempo que modifica, reafirma a totalidade, pois sua diferença repercute nos demais e não o separa deles.

Desse modo, na unidade processual que a análise da linguagem começa a 
desvendar, sentido e existência não podem mais ser opostos como termos exclusivos e independentes, apontando ao contrário para a necessidade de uma compreensão ontológica que não opere com a cisão entre o subjetivo e o objetivo. Inseparável da contingência, o sentido perde sua positividade, torna-se lacunar e processual, inseparável da configuração concreta em que se realiza. Afasta-se, assim, a possibilidade da língua e do sentido como objetos ideais, postos por um sujeito desengajado; correlativamente, a subjetividade perde seu poder absolutamente constituinte e se vê agora em relação com um sentido que não se deixa abarcar, que não se oferece de modo translúcido ou objetivo, portador de uma compossibilidade e de uma consistência próprias que lhe escapam. Imersa no mundo e no tempo, por eles estruturada, a lógica orgânica operante na linguagem não pode pretender-se eterna ou acabada, não pode ser um objeto inteiramente determinado, pois o que a forma não é o trabalho subjetivo de constituição, e sim a síntese espontânea e aberta intrínseca aos próprios fenômenos e fatos: "[o sistema] comporta sempre mudanças latentes ou em incubação, nunca é feito de significações absolutamente unívocas que se possam explicitar integralmente ao olhar de uma consciência constituinte transparente" ${ }^{\text {"50 }}$.

Se a linguagem opera como auto-diferenciação, se há uma espécie de abertura interior que a anima - sua dimensão relacional e intencional feita por horizontes e por auto-referência -, o sentido por ela engendrado não pode ser da ordem do objeto, permanecendo ao contrário como um misto de transcendência e imanência, presença e ausência simultâneas, nem dado previamente e nem absolutamente imotivado - ou seja,

50 MERLEAU-PONTY, Maurice. Sobre a fenomenologia da linguagem, in: Signos, São Paulo: Martins Fontes, 1991, p. 92 
sua abertura é ainda linguagem, embora na forma do virtual, do possível, ou do porvir: "A relação do sentido com a palavra já não pode ser essa correspondência ponto por ponto (...) A ausência do signo pode ser um signo e a expressão não é o ajustamento de um elemento do discurso a cada elemento do sentido, mas sim uma operação da linguagem sobre a linguagem que instantaneamente se descentraliza para seu sentido" ${ }^{21}$. O sentido se realiza pois como descentramento do conjunto; a abertura e a transcendência por meio das quais ele se forma não são movimentos extrínsecos à linguagem, mas sua própria dinâmica interna afirmando-se como diferenciação ou "deformação coerente" ${ }^{52}$, reorganização interna que envolve a totalidade e, por isso mesmo, a preserva; movimento único e espontâneo que antecede a cisão entre sujeito e objeto, através do qual os signos ao mesmo tempo se constituem como singularidade e se generalizam como significação:

“(...) as palavras, as formas mesmas, para uma análise orientada como essa, logo aparecem como realidades segundas, resultados de uma atividade de diferenciação mais originária. As sílabas, as letras, os torneios e as desinências são os sedimentos de uma diferenciação que, desta vez, precede sem dúvida nenhuma a relação entre signo e significação, pois é ela que torna possível a distinção mesma dos signos: os fonemas, verdadeiros fundamentos da fala, já que se descobrem pela análise da linguagem falada e não têm existência oficial nas gramáticas e nos dicionários, por si mesmos não querem dizer nada que se possa designar. Mas, justamente por essa razão, eles representam a

\footnotetext{
51 MERLEAU-PONTY, Maurice. A linguagem indireta e as vozes do silêncio, in: Signos, São Paulo: Martins Fontes, 1992, p. 44

52 Trataremos de forma mais detida dessa noção ao estudarmos a questão do estilo.
} 
forma originária do significar, eles nos fazem assistir, por baixo da linguagem constituída, à operação prévia que torna simultaneamente possíveis a significação e os signos discretos."

Uma vez compreendido, como ensina a lingüística de Saussure, que os signos - e mesmo antes deles, os fonemas, elementos primários da língua - não são senão diferenças no interior de uma unidade necessariamente implicada por eles; que essa unidade, por isso mesmo, dispõe de uma lei intrínseca ou de um sentido que não são o da identidade, mas precisamente o da mudança e do movimento, da passagem ao outro e da referência para fora de si, as noções de signo e significado como entidades positivas e exclusivas perde sua validade. Enquanto diferenciação, a linguagem significa não "colando" um signo a um significado, mas sim criando um universo ou uma totalidade processual que se afirma justamente pela lógica operante em suas transformações, pelo sentido constante implicado por suas mudanças: "O que aprendemos com Saussure foi que os signos um a um nada significam, que cada um deles exprime menos um sentido do que marca um desvio de sentido entre si mesmo e os outros. Como se pode dizer o mesmo destes, a língua é feita de diferenças sem termos, ou mais exatamente, os termos nelas são engendrados apenas pelas diferenças que aparecem entre eles" ${ }^{\text {54 }}$. Há unidade porque a diferenciação interna afirma uma coerência e uma organicidade do conjunto; há diferença, porque esse conjunto afirma-se por auto-descentramento. Aquém da linguagem constituída,

${ }_{53}$ MERLEAU-PONTY, Maurice. A prosa do mundo, São Paulo: Cosac \& Naify, 2002, p. 55, 56

54 MERLEAU-PONTY, Maurice. A linguagem indireta e as vozes do silêncio, in: Signos, São Paulo: Martins Fontes, 1992, p. 39 
da cisão entre signos objetivos e significações subjetivas, há uma dimensão pré-objetiva em que a linguagem opera discriminando entidades elas próprias opositivas e diacríticas, isto é, há uma dimensão em que ela é pura diferenciação ${ }^{55}$ - mas uma diferenciação orientada, dotada de uma lógica interna, e por isso mesmo capaz de construir para si um mundo e uma totalidade articulados, de fazer existir um sentido e uma significação originários: "Antes que a linguagem carregue as significações que nos ocultam sua operação tanto quanto a revelam, e que, uma vez nascidas, parecerão simplesmente coordenadas a signos inertes, é preciso que ela secrete por seu arranjo interno um certo sentido originário do qual as significações serão extraídas."

Longe de qualquer noção de realismo clássico, o que responde pela significação da linguagem não é sua adequação a uma realidade objetiva ou sua capacidade de designar um pensamento que existiria para si, mas sim sua dinâmica e sistematicidade próprias, a solidez com que estrutura um todo coerente e harmônico, espécie de racionalidade espontânea, como veremos mais adiante, que se assenta no fato de que cada elemento não é senão um testemunho e uma confirmação dos demais, uma certa retomada e uma certa antecipação dos outros, garantindo para seu devir um sentido constante, para sua articulação uma coerência intrínseca. É pela unidade do todo que a linguagem significa, pela força interna com que se articula e que faz da diferença a confirmação do vínculo que ata cada uma de suas partes:

\footnotetext{
55 “(...) Uma língua é menos uma soma de signos (...) do que um meio metódico de discriminar signos uns dos outros, e de construir assim um universo de linguagem (...) Falar não é ter à disposição um certo número de signos, mas possuir a língua como princípio de distinção.” (MERLEAU-PONTY, Maurice. A prosa do mundo, São Paulo: Cosac \& Naify, 2002, p. 54,55).

56 MERLEAU-PONTY, Maurice. A prosa do mundo, São Paulo: Cosac \& Naify, 2002, p. 53
} 
“(...) a linguagem não pressupõe sua tabela de correspondências, ela mesma desvela seus segredos, ensina-os a toda criança que vem ao mundo, é inteira mostração. Sua opacidade, sua obstinada referência a si mesma, suas retrospecções e seus fechamentos em si mesma são justamente o que faz dela um poder espiritual: pois torna-se por sua vez algo como um universo capaz de alojar em si as próprias coisas - depois de as ter transformado em sentido das coisas" ${ }^{25}$. A linguagem não é decalque porque ela é a operação mesma pela qual se forma uma unidade dotada de consistência e articulação próprias $^{58}$, existência estruturalmente significativa ou sentido existencial, assegurados pela compossibilidade originária de seus elementos: "A linguagem nos conduz às coisas mesmas na exata medida em que, antes de ter uma significação, ela é significação" ${ }^{\text {" }}$. Sistema integrado por uma lógica latente e espontânea, a linguagem revela um sentido que encontra em sua configuração concreta o encadeamento e a ligação que asseguram sua coerência; longe de um meio ao qual a significação recorreria para se exprimir, a linguagem é ela mesma a operação de constituição da significação, "poder espiritual" capaz de fazer do sentido existência e da existência sentido: "Muito mais do que um meio, a linguagem é algo como um ser, e é por isso que consegue tão bem tornar alguém presente para nós (...) O sentido é o movimento total da fala, e é por isso que nosso pensamento demora-se na fala. Por isso também a transpõe como o gesto ultrapassa os seus pontos de passagem."60

57 MERLEAU-PONTY, Maurice. A linguagem indireta e as vozes do silêncio, in: Signos, São Paulo: Martins Fontes, 1992, p. 43

58 De acordo com a noção de mundo presente na Fenomenologia da Percepção, como tentamos mostrar em nossa pesquisa de Mestrado (MOURA, Alex de Campos. Liberdade e situação em Merleau-Ponty: uma perspectiva ontológica, São Paulo: Humanitas, 2010).

59 MERLEAU-PONTY, Maurice. A prosa do mundo, São Paulo: Cosac \& Naify, 2002, p.36

${ }^{60}$ MERLEAU-PONTY, Maurice. A linguagem indireta e as vozes do silêncio, in: Signos, São Paulo: Martins 
Explicita-se, assim, a dimensão ontológica da linguagem, sua compreensão como um Ser, capaz de tornar presente, existência concreta que espontaneamente conduz ao sentido e vice-versa. Desse modo, tal como já ocorria em seu estudo sobre a estrutura e a percepção, o Ser de que se ocupa Merleau-Ponty não é aquele que se resignaria à oposição clássica entre o objetivo e o subjetivo, ser como em si e ser para si - ponto central para se pensar a proximidade entre suas "duas fases". Ao contrário, como estamos procurando indicar, o Ser descrito por ele é feito precisamente da fusão ou da passagem de um ao outro, "significação" ou "lógica" encarnadas, respondendo por um tipo de unidade e de síntese que necessitam da abertura e da multiplicidade para se constituírem; ele não é, portanto, nem objeto e nem sujeito, mas uma unidade significativa que se realiza como auto-diferenciação, conformação de cada um de seus elementos a uma articulação mais ampla, atando o singular a uma generalidade que o ultrapassa mas que depende dele para encarnar-se.

Desse modo, a linguagem atua não como representação (noção central na ontologia clássica), mas como transformação do signo em significado, dinâmica que refere a parte ao todo e cria com isso uma unidade dotada de sentido próprio; mais precisamente, ela significa transformando-se ela própria nesse sentido e nessa totalidade, fazendo-os existir. A verdade da expressão não se encontra em sua adequação ao exprimido, porque aqui um e outro permanecem atados, a expressão é a realidade do exprimido, sua existência, bem como o exprimido é o que articula a expressão; a linguagem - e, como

Fontes, 1992, p. 43 
veremos, esse é um dos pontos que a aproxima do corpo perceptivo - se torna o sentido em questão, assume fazendo existir como realidade a significação para a qual se abre, não como objeto, mas como unidade comum de seus elementos: “(...) a linguagem nunca diz nada, ela inventa uma gama de gestos que apresentam entre si diferenças suficientemente claras para que a conduta da linguagem, à medida que se repete, se recorta e se confirma ela própria, nos forneça de maneira irrecusável a feição e os contornos de um universo de sentido."

Assim, se Merleau-Ponty pode afirmar que a linguagem é um Ser, é porque, antes da oposição entre signo e significação, ela se revela como a passagem espontânea pela qual o sentido se torna existência concreta e a existência concreta se torna sentido, ou seja, ela se revela como uma unidade em que o para si e o em si formam um todo orgânico, inseparável e uníssono, em que signo e significado não podem dissociar-se, formando um sentido que não é senão a constância ou a coerência implicada pelas condutas de seus elementos estruturais; se a linguagem "não diz nada", é porque não há entre ela e o sentido uma relação de designação: antes, ela se transforma no sentido, torna-se a própria aparição ou a presença indireta da significação. Tal como a temporalidade, no estudo da percepção, respondia pela encarnação do sentido, pela comunicação entre o subjetivo e o objetivo, também a linguagem adquire agora uma dimensão ontológica, ao se oferecer como fusão entre matéria e espírito, estrutura que faz a significação ser no mundo. Ela recusa a oposição das ontologias clássicas porque se coloca num plano anterior ao delas: o sentido da linguagem - assim como o do percebido - se oferece espontaneamente pela articulação 
interna aos signos, forma um Ser cuja significação decorre de sua auto-diferenciação e de seu descentramento, unificado porém por uma lógica interna, concreta e operante, que escapa tanto às categorias do sujeito quanto às do objeto, apontando para a indissociabilidade de ambos.

A análise da linguagem, e em especial os desdobramentos da linguística de Saussure, ao desvelarem um todo orgânico, implicam a impossibilidade de se conceber o pensamento e a consciência como instâncias autônomas, a situação sem significação e o sentido sem existência, demandando uma outra compreensão ontológica. Se não há significação que se ofereça inteiramente e sem qualquer vínculo com os signos, não há uma instância separada em que o pensamento e o sujeito se formariam e se reconheceriam de modo absoluto; correlativamente, não há uma instância em que a significação se realizaria completamente, em que assumiria a inteira determinação do objeto. Assim como a noção de sentido passa por uma reconfiguração quando se reconhece esse ser espontâneo de que a linguagem dá testemunho, também a noção de sujeito não poderá manter-se intacta.

É precisamente a reformulação desses termos um dos pontos em que insistem as descrições da Prosa do Mundo, retomando o fato de que, se é verdade que a linguagem parece nos conduzir às próprias coisas ou ao próprio sentido, se temos a sensação de alcançar diretamente o pensamento daquele que fala, isso não ocorre porque ela seria o mero índice de significações já dadas em um universo inteligível, veículo de 
pensamentos determinados ${ }^{61}$ que reafirmariam a cisão clássica entre o subjetivo e o objetivo. Ao contrário, isso se deve, como vimos, à sua própria operação, e longe de implicar uma subjetividade transcendental e uma objetividade pura, o que esse movimento revela é um sujeito capaz de inserir-se em uma dinâmica que o ultrapassa e que não provém de si: uma vez compreendido que a síntese é interna à linguagem, que a articulação dos fenômenos é um movimento espontâneo realizado por sua existência concreta e, finalmente, que o sentido assim formado permanece aberto e intencional, torna-se necessário reconhecer que a subjetividade que apreende esse sentido não pode mais ser considerada uma esfera autônoma e constituinte, pura posição do objeto, dispondo necessariamente de uma abertura àquilo que the é outro: "A psicologia nos faz redescobrir com o 'eu falo' uma operação, relações e uma dimensão que não são as do pensamento (...) Já 'eu penso' significa: há um certo lugar chamado eu, onde fazer e saber que se faz não são diferentes, e o eu se confunde com sua própria revelação, onde portanto nenhuma intrusão do exterior é sequer concebível. Esse eu não poderia falar. Aquele que fala entra num sistema de relações que o supõem e o tornam aberto e vulnerável"62.

Chegando a uma das questões centrais na análise da linguagem, é preciso reconhecer agora que a "interioridade" de que ela dispõe, sua ecceidade e auto-formação, recusam a subjetividade transcendental pura, revelando ao contrário a relação com a alteridade como traço originário ou ontológico de um homem para quem o sentido se apresenta sempre em um movimento de pré-constituição. Não se trata, porém, do

\footnotetext{
Idem, p. 27, 28

62 Idem, p. 39
} 
reconhecimento de uma abertura ao absolutamente outro, pois ao considerar a subjetividade não como "eu penso" e sim como "eu falo", o filósofo recusa uma vez mais a distinção completa entre linguagem e subjetividade, existência e significação, reconhecendo “(...) a situação confusa de um ser que é aquilo que fala”, ou seja, a consistência própria à linguagem não a opõe ao sujeito porque também ele é linguagem ${ }^{63}$, e aqui, ao invés da mútua exclusão, será novamente a noção de diferença que relacionará os termos envolvidos. Detentora de uma alteridade que nem se opõe e nem se identifica ao sujeito, de uma consistência que o ultrapassa mas da qual ele participa e compartilha o movimento, a linguagem revela-se envolvida em uma dimensão ou uma condição ontológica mais geral: a abertura do sujeito ao que lhe é "outro", sua abertura estrutural e sua referência espontânea à alteridade: "É que o falar e o compreender são os momentos de um único sistema euoutrem, e o portador desse sistema não é um eu puro (que veria dentro dele apenas um de seus objetos de pensamento e se colocaria diante de), é o eu dotado de um corpo e continuamente ultrapassado por esse corpo, que às vezes the rouba seus pensamentos para atribuí-los a si ou para imputa-los a um outro. Por minha linguagem e por meu corpo, sou acomodado ao outro." ${ }^{64}$

Assim como o $\operatorname{corpo}^{65}$, em sua análise da percepção, significava para Merleau-Ponty não um objeto desdobrado por uma consciência, mas a abertura de um sujeito constitutivamente ligado ao mundo, simultaneamente ativo e passivo em sua relação

\footnotetext{
63 Esse ponto será explicitado na segunda parte do capítulo.

64 MERLEAU-PONTY, Maurice. A prosa do mundo, São Paulo: Cosac \& Naify, 2002, p. 40

65 Essa questão será retomada no próximo capítulo.
} 
com um percebido que se oferecia na forma do "em-si-para-nós" "66, também aqui a consistência revelada no interior da linguagem conduz a um sujeito que não pode encerrarse sobre si, que não domina suas significações, que antes é ultrapassado por elas graças ao movimento espontâneo e interno que conduz dos signos ao sentido, lógica operante intrínseca à linguagem que o coloca necessariamente em relação com o diverso; se o signo não é mais o objeto no qual a subjetividade se reconheceria, mas a abertura ou a referência a uma unidade espontânea e latente que lhe é constitutiva, o próprio sujeito deixa de poder definir-se como identidade, pois sua inserção na linguagem o torna participante desse movimento e dessa abertura internos que conduzem sempre para fora e para o que é outro. Do mesmo modo como a significação do percebido, ao estruturar-se espontaneamente na unidade do tempo e do mundo, revelava uma dimensão aberta e generalizada do sujeito, também aqui a consistência própria ao sentido implica o descentramento daquele que o reconhece: "O eu que fala está instalado em seu corpo e em sua linguagem não como numa prisão, mas, ao contrário, como num aparelho que o transporta magicamente à perspectiva do outro (...) Não há fala (e em última instância personalidade) senão para um 'eu' que traz em si esse germe de despersonalização. Falar e compreender não supõem somente o pensamento, mas, de maneira mais essencial e como fundamento do próprio pensamento, o poder de deixar-se desfazer e refazer por um outro atual, por vários outros possíveis e, presumivelmente, por todos." ${ }^{67}$

O que a linguagem testemunha, e esse ponto é central para nossa Tese, não

\footnotetext{
66 Noção central na Fenomenologia da Percepção.

67 MERLEAU-PONTY, Maurice. A prosa do mundo, São Paulo: Cosac \& Naify, 2002, p. 41, 42
} 
é o trabalho constituinte de uma consciência fechada sobre si, mas a abertura orgânica do eu, seu descentramento e vulnerabilidade como estruturas originárias de uma existência na qual o sentido "brota" espontaneamente de seu comércio com aquilo que the é outro. Reencontramos, assim, uma questão nuclear na filosofia de Merleau-Ponty: a afirmação da consistência própria ao sentido - seja do mundo, da linguagem ou de outrem - e seu correlato desdobramento como abertura do sujeito, que se reconhece portador de uma dimensão situacional e passiva. Em todos os casos, trata-se de um mesmo movimento, de uma mesma condição existencial, pela qual a subjetividade se abre a algo que the é outro, embora não absolutamente diverso, diferença de si e descentramento. Assim como ocorria no estudo da percepção ${ }^{68}$, a análise de Merleau-Ponty conduz da atividade sintética do eu a um tipo de síntese de emparelhamento ou de transição ${ }^{69}$, operante espontaneamente no próprio "objeto" (no percebido, na linguagem e em outrem), e que recusa por isso mesmo a possibilidade de uma objetividade e de uma subjetividade puras. A gênese do sentido, assim, deixa de se resguardar em uma esfera subjetiva autônoma, desdobrando-se no campo até então considerado desprovido de significação própria, o campo da matéria e da multiplicidade, do devir e da mudança, pondo em questão a própria oposição clássica entre sentido e história, razão e contingência. A racionalidade não pode mais expressar uma pura atividade sintética, um ato absoluto e eterno que escaparia à toda situação e à toda

${ }^{68}$ A noção de síntese de transição ou de síntese passiva, conforme procuramos mostrar em nossa pesquisa de Mestrado, era central na Fenomenologia da Percepção. Realizando-se como dinâmica temporal, ela oferecia uma articulação interna entre as partes, unidade espontaneamente prefigurada pela diversidade de seus momentos concretos, pondo em questão a compreensão clássica da subjetividade como instância absolutamente constituinte e do objeto como absolutamente constituído, apontando para um tipo de fusão entre eles.

${ }^{69}$ MERLEAU-PONTY, Maurice. A prosa do mundo, São Paulo: Cosac \& Naify, 2002, p. 41, 42 
condição; ao contrário, a compossibilidade própria aos termos concretos de uma língua ata toda ação a uma articulação que a ultrapassa, solicita e engloba, respondendo por uma síntese ou por uma racionalidade espontânea que desconhece a cisão entre unidade subjetiva e diversidade objetiva, estruturando-se como sentido geral de sua autodiferenciação.

Para explicitar essa questão, Merleau-Ponty retoma o exemplo do momento em que uma língua cria um novo meio de expressão, transformando o que era decadência em princípio novo, desinvestindo e reinvestindo as palavras. Como vimos, trata-se de um movimento espontâneo da língua, de uma articulação entre diacronia e sincronia que não Ihes vem do exterior, mas antes as constitui como um só movimento. A linguagem assume o que era acaso e o insere dentro de uma totalidade ou de uma sistematicidade que o recupera como valor expressivo, isto é, que o torna um termo significativo dentro de uma lógica mais ampla: "De que maneira compreender esse momento fecundo da língua, que transforma acaso em razão e, de um modo de falar que desaparecia, faz de repente um novo, mais eficaz, mais expressivo (...)?"70. Não se trata, mostra ele, nem de uma deliberação dos sujeitos falantes, dada a hesitação do acontecimento, e nem de uma soma de mudanças parciais, dada a sistematicidade e a conivência dos fatos aí implicados ${ }^{71}$; mas sim da reafirmação da dinâmica e da lógica operante próprias à linguagem. A ideia de uma consciência que garantiria, do exterior, a sistematicidade, a coerência, e a unidade no interior de uma língua, é substituída pelo movimento espontâneo e articulado assegurado

\footnotetext{
70 Idem, p. 57

$71 \quad$ Idem, p. 57
} 
pela própria constituição dos signos como entidades referenciais e diacríticas, que necessariamente afirmam uma unidade e um sentido constantes para as mudanças e as passagens entre os momentos de uma língua, impedindo que haja um elemento absolutamente estranho ou imotivado dentro do sistema. Se cada elemento, como vimos, não é senão sua passagem aos demais, o princípio e a atividade unificadora são intrínsecos ao movimento e à mudança, e na língua todo termo contingente é incorporado pela razão ou pelo sentido de seu movimento geral, assim como todo sentido e todo movimento recorrem sempre à organicidade desses termos para realizarem-se: "A língua é inteiramente acaso e inteiramente razão, porque não há sistema expressivo que siga um plano e que não tenha sua origem num dado acidental qualquer, mas também não há acidente que se torne instrumento linguístico sem que a linguagem tenha insuflado nele o valor de uma nova maneira de falar (...) E nem mesmo devemos colocar em dois (?) distintos o fortuito e o racional, como se os homens trouxessem a ordem e os acontecimentos, a desordem. A própria vontade de expressão é ambígua e contém um fermento que trabalha para modificála: cada língua, diz por exemplo Vendryès, é submetida à cada momento às necessidades gêmeas e contrárias de expressividade e de uniformidade"72

Mesmo a vontade deliberada, a intenção aparentemente pura, que poderia repor a idéia do sujeito autônomo e da razão como uma de suas faculdades, reaparece investida por uma dimensão que a generaliza, por uma espécie de "fraqueza interna" que a impede de se fechar sobre si, de manter-se idêntica e imune ao "exterior"; enquanto

72 Idem, p. 58 
unidade constante feita por auto-diferenciação, a língua não pode trazer algo absolutamente novo e sem qualquer vínculo com seus outros elementos, não pode inserir um termo sem que este imediatamente, por sua própria estrutura, ecoe e reverbere nos demais, equilibrando-se entre o que traz e o que recebe dos outros. A compreensão de um modo de falar, por exemplo, exige que ele seja conhecido o suficiente para ser entendido, e novo o bastante para não cair na indistinção ${ }^{73}$ - ou seja, implica que ele não seja nem uma inteira novidade, ruptura absoluta sem relações com o disponível, e nem uma inteira aquisição, repetição de uma condição dada, desprovida de relevo - sendo na relação entre o disponível e o novo, o dado e a criação, que a força expressiva da linguagem se coloca, operando como uma espécie de "deformação coerente" ou de descentramento do passado, torção que gera um novo porvir, nem determinado (pois há mudança) e nem independente (pois ela é mudança desse passado).

Reencontramos, pois, implícita em sua análise da linguagem, uma outra questão central da filosofia de Merleu-Ponty, já presente em seus estudos sobre a percepção: a relação entre liberdade e situação, criação e continuidade, bem como seu desdobramento em uma significação temporal. Por um lado, a linguagem não cria de modo absoluto, pois cada termo expressa uma relação e uma continuidade com os demais, com o passado em geral, não sendo senão uma certa abertura e relação em um sistema prefigurado; por outro, cada um deles, embora nada signifique por si e apenas expresse a totalidade, não pode, enquanto diferença, ser idêntico aos demais, apresentando-se

\footnotetext{
73 Idem, p. 58
} 
necessariamente como outro e como singular. Em cada um de seus movimentos, a linguagem ao mesmo tempo preserva e renova: se seu fluxo mantém uma unidade já em curso, ele o faz precisamente alterando o dado, abrindo-o rumo a um termo ou a um porvir novo, isto é, diferenciando-se de si mesma. Ao invés de uma pura ação - uma liberdade absoluta, que romperia com todo o dado e traria o absolutamente novo - ou de uma pura passividade - uma aquisição determinante e instransponível - a linguagem, vimos, opera como diferenciação, isto é, como a distância interna que impede simultaneamente a coincidência e a ruptura, atando o devir à continuidade: “(...) todo o seu poder de expressão [da linguagem] vem do fato de que ela não é idêntica a suas concorrentes. Exprimir-se é portanto um empreendimento paradoxal, uma vez que supõe um fundo de expressões aparentadas, já estabelecidas, e que sobre esse fundo a forma empregada se destaque, permaneça suficientemente nova para chamar a atenção. Trata-se de uma operação que tende à sua própria destruição, uma vez que se suprime à medida que se propaga, e se anula se não se propaga"74. Não há na linguagem uma pura atividade e nem um puro determinismo porque exprimir é simultaneamente afirmar um fundo constante e uma forma nova; é, mais ainda, afirmar a recíproca constituição entre um e outro, revelando-os como momentos intercambiáveis de um único processo de diferenciação, pelo qual, como vimos, se constitui simultaneamente a singularidade ou a novidade do signo e a generalidade ou a continuidade do sentido.

Aquilo mesmo que torna a expressão comunicável e participável, só o faz

\footnotetext{
74 Idem, p. 58
} 
privando-a de parte de sua especificidade, inserindo-a e distendendo-a no movimento mais amplo pelo qual a linguagem adquire a consistência que a torna significativa, unificação que tende a desdiferenciar seus elementos: como vimos, a abertura que cada elemento novo traz, ao mesmo tempo que o singulariza, o remete para fora de si, atando-a a uma generalidade que ele não contém e não domina, na qual afasta-se de si , passa aos outros, e se transforma. É por essa razão que todo ato expressivo, como afirma Merleau-Ponty, comporta duas dimensões: seu sentido "direto", quando tomado por si só, e o sentido que assume no conjunto, ao entrar no interior da linguagem, incorporando-se e implicando uma reconfiguração do todo. Como mostra o exemplo de Matisse ${ }^{75}$, cujo ato de pintar foi filmado e reproduzido em câmera lenta ${ }^{76}$, Merleau-Ponty mostra que se seus gestos dispunham de uma face explícita, o traço por si, eles ao mesmo tempo revestiam-se de uma significação indireta, o efeito que esse gesto produzia no conjunto, suas implicações e desdobramentos, incomensuráveis com sua existência individual. Tomado em si mesmo, o traço, assim como a palavra considerada isoladamente, não é senão o avesso do trabalho de criação, pois é apenas sua entrada no conjunto, sua participação e relação com os outros elementos, que o transformam em sentido: "A linguagem é por si oblíqua e autônoma e, se lhe acontece significar diretamente um pensamento ou uma coisa, trata-se apenas de um poder secundário, derivado de uma vida interior. Portanto, como o tecelão, o escritor trabalha pelo avesso: lida apenas com a linguagem, e é assim que de repente se encontra rodeado de

75 O exemplo de Matisse, bem como a discussão sobre a relação entre liberdade e situação, serão retomados no capítulo seguinte.

76 MERLEAU-PONTY, Maurice. A linguagem indireta e as vozes do silêncio, in: Signos, São Paulo: Martins Fontes, 1992, p. 46 
sentido" ${ }^{\prime 7}$.

Como o da linguagem ${ }^{78}$, o sentido do quadro - conforme os capítulos seguintes procurarão explicitar - não se encontra em cada um dos gestos individuais que constrói, não é engendrado por uma atividade autônoma, pois sua estruturação se realiza precisamente como generalização espontânea de toda singularidade, transformação de cada parte em diferença ou referência ao todo; cada elemento, e cada ato que o faz, transcendem-se espontaneamente rumo a uma totalidade que eles não contêm, generalizam-se e diferenciam-se de si mesmos. Assim, se o ato expressivo não pode ser considerado nem uma pura deliberação subjetiva e nem um efeito objetivo, é porque cada gesto ao mesmo tempo que age sobre o conjunto, transformando-o, sofre sua ação e é por ele modificado. Se a linguagem é descentramento, a diferença que singulariza cada ato torna-se também auto-diferenciação, afastamento de si e generalidade. Matisse olhou o conjunto aberto e levou o pincel para o traçado que o chamava, para que o quadro fosse o que estava em vias de tornar-se ${ }^{79}$, havendo portanto escolha, já que tratava-se de satisfazer condições informuláveis por qualquer outro que não ele, definidas e impostas unicamente pela intenção de fazer "(...) aquele quadro que ainda não existia" ${ }^{80}$ - mas por isso mesmo essa decisão não dispunha de um número infinito de possibilidades diante de si, ela seguia uma lógica tácita, respondia a uma demanda implícita imposta pela própria consistência do

\footnotetext{
77 Idem, p. 45

78 Prenunciada aqui, a relação entre pintura e linguagem será trabalhada de modo mais detido no segundo capítulo.

79 MERLEAU-PONTY, Maurice. A linguagem indireta e as vozes do silêncio, in: Signos, São Paulo: Martins Fontes, 1992, p. 46

80 Idem, p. 46
} 
todo, pelas escolhas já feitas, pelo passado e pelo porvir que a estrutura em construção prefigurava: “(...) Matisse, instalado num tempo e numa visão de homem, olhou o conjunto atual e virtual de sua tela e dirigiu sua mão para a região que chamava o pincel, para que o quadro fosse enfim o que ele se tornava"81. Ele não tinha, pois, um vazio absoluto diante de si, em relação ao qual seu gesto não seria senão a afirmação de sua absoluta liberdade; havia já como que uma convergência dos elementos disponíveis, uma unidade e uma coerência das partes que apontavam para uma decisão comum, para a possibilidade que responderia ao projeto em curso. O possível aqui, o campo em que a liberdade se desdobra, não é portanto o de uma negatividade absoluta, ruptura completa com todo o dado, pois a articulação espontânea do sentido garante um fundo ou um solo constante, implica direções privilegiadas, fazendo com que o passado necessariamente seja retomado, ainda que por um movimento de diferenciação: "noção de possível: não surgimento arbitrário, ex nihilo - mas aparecimento lateral de um aparelho de sentido que só aos poucos manifesta seu conteúdo..." ${ }^{82}$. A espontaneidade do sentido, do mesmo modo que recusa o signo como ser inteiramente determinado e explícito, recusa também a subjetividade como pura negação, não ser absoluto, estabelecendo uma comunicação interna entre os diferentes momentos de uma língua que recusa tanto a pura contingência quanto a pura determinação, formando uma unidade processual em que o sentido se desvela gradualmente, mas sempre como expressão da relação de suas partes.

\footnotetext{
81 MERLEAU-PONTY, Maurice. A prosa do mundo, São Paulo: Cosac \& Naify, 2002, p. 68

82 Idem, p. 69
} 
Enfim, o que já a Fenomenologia da Percepção indicava, e que reaparece no estudo da linguagem, é a constatação de que a atividade expressiva - seja ela operada pela percepção ou pela linguagem - realiza internamente a passagem do múltiplo à significação, dispondo de uma estruturação própria que não se reduz às categorias de forma e matéria, sentido e objeto. Do mesmo modo como os signos são entidades referenciais que espontaneamente formam uma unidade e um sentido comuns, as perspectivas, os vários aspectos de um objeto, só se realizam e se manifestam como expressões de uma totalidade que eles compartilham sem conter, totalidade latente de onde retiram sua significação - o que nos permite tornar mais precisa a relação entre linguagem e percepção:

"A significação dos signos é primeiro sua configuração no uso, o estilo das relações inter-humanas que deles emana; e somente a lógica cega e involuntária das coisas percebidas, inteiramente ligada à atividade de nosso corpo, pode nos fazer entrever o espírito anônimo que inventa, no coração da língua, um novo modo de expressão. As coisas percebidas não seriam para nós irrecusáveis, presentes em carne e osso, se elas não fossem inesgotáveis, jamais inteiramente dadas."

Não se trata, portanto, de uma analogia, mas do reconhecimento de que, tanto em uma quanto em outra, a expressão opera internamente por auto-diferenciação e referência entre suas partes, recusando as noções clássicas do objeto e da subjetividade como instâncias opostas: a significação e a unidade são engendradas por sua existência concreta e mutável, assim como essa segue a lógica tácita e latente de seu sentido 
constante. Em ambas, o que se revela é uma mesma espontaneidade - à qual retornaremos nas análises seguintes - pela qual o signo abre-se a uma significação, espécie de racionalidade concreta que sustenta a alteridade do sentido, descentrando o sujeito e revelando aquilo que ele não poderia saber senão por elas. É a própria linguagem, como é o próprio percebido, que conduzem do dado ao sentido, do fenômeno à totalidade: a passagem de um ao outro é a estrutura de seu Ser como diferença e unidade. Elas compartilham, enfim, de uma mesma "significação metafísica", isto é, elas atestam relações para além do encadeamento causal que se poderia supor para o mundo objetivo ${ }^{83}$; mas essas relações permanecem inseparáveis de sua existência concreta, repõem uma lógica tácita e uma passagem espontânea que têm início em cada ato perceptivo e em cada palavra, assegurando a consistência própria do Ser percebido e do Ser da linguagem.

Assim, como afirma Merleau-Ponty ao término de seu ensaio Sobre a Fenomenologia da Linguagem, a peculiaridade da fenomenologia, e especialmente da fenomenologia da linguagem, está em se estabelecer no campo de uma "espontaneidade ensinante", isto é, nesse território em que uma síntese ou uma lógica processual forma espontaneamente uma significação aberta, que opera sobre o sujeito, descentrando-o na relação com uma alteridade que ele não engendra. Sustentando nossa hipótese de trabalho, essa espontaneidade, presente na linguagem, na percepção e na relação com outrem, ata as temáticas trabalhadas pelo filósofo, faz com que elas partilhem de uma mesma ontologia implícita, feita pela reversibilidade estrutural entre o uno e o múltiplo, o

83 MERLEAU-PONTY, Maurice. A prosa do mundo, São Paulo: Cosac \& Naify, 2002, p. 61 
sentido e a existência - como os capítulos seguintes buscarão também mostrar. 


\section{Linguagem e pintura: a gênese espontânea do Ser}

1. Introdução

Na primeira parte deste capítulo ${ }^{84}$, procuramos mostrar como a análise da linguagem feita por Merleau-Ponty desdobra certas questões já levantadas por seu estudo sobre a percepção, recuperando o projeto mais amplo do filósofo de recusa da ontologia clássica baseada na oposição entre sujeito e objeto ${ }^{85}$. Neste segundo momento do capítulo, prosseguindo essa discussão, nos concentraremos em seu estudo sobre a relação entre linguagem e pintura. Como veremos, ao aproximar as duas atividades, Merleau-Ponty recupera o vínculo entre expressão e percepção, bem como as implicações ontológicas de

84 Conforme o capítulo anterior.

85 Também indicada no capítulo anterior, essa é uma das questões centrais de nossa pesquisa de Doutorado, sendo apontada em diversos momentos ao longo da Tese. 
todo gesto expressivo. Partindo da comparação entre as duas áreas, poderemos reconhecer a comunicação interna que a estrutura perceptiva mantém com a expressão, apontando para um tipo de síntese ou de racionalidade que opera descentrando e transformando o mundo percebido, configuração de significações abertas e processuais que escapam à alternativa entre o subjetivo e o objetivo.

Dentro do estudo mais amplo de Merleau-Ponty sobre a linguagem, sua comparação com a pintura cumpre um papel metodológico preciso: realizar uma "redução"86 capaz de revelar aquilo que se dissimula no uso cotidiano das palavras, a camada préobjetiva oculta e suposta pelas significações inteiramente determinadas e objetivas ${ }^{87}$. A comparação deve ser capaz de mostrar que a linguagem dispõe de uma dimensão operante ou tácita, espécie de "silêncio" estruturante em que as palavras se organizam por uma lógica própria, dispõem-se segundo uma dinâmica interna que não recorre a nenhum telos pré-determinado, mas o institui ${ }^{88}$ pelo arranjo processual de suas partes, respondendo por uma significação que não se reduz nem a um fato objetivo e nem a uma construção

86 Como já ocorria na Fenomenologia da Percepção (conforme nossa pesquisa de Mestrado), o sentido em que Merleau-Ponty faz uso da "redução" é bastante diverso de sua matriz husserliana. Tanto no estudo de 1945 quanto agora, como veremos, ela se torna um método indireto encarregado de revelar, ao invés do domínio dos puros noemas, justamente o seu avesso: a inseparabilidade entre essência e existência, entre a ordem do sentido e a da facticidade. Ao se deparar com a impossibilidade de se realizar completamente, de oferecer seu objeto como pura idealidade, ela nos conduz a um campo pré-objetivo que antecede o corte entre sujeito e objeto.

87 "Se queremos compreender a linguagem em sua operação significante original, precisamos fingir nunca ter falado, operar sobre ela uma redução sem a qual ela ainda se ocultaria a nossos olhos reconduzindo-nos ao ao que nos significa, precisamos olhá-la como os surdos olham os que falam, e comparar a arte da linguagem às outras artes da expressão que não têm recurso a ela, tentar vê-la como uma dessas artes mudas." (MAURICE, Merleau-Ponty. A prosa do mundo, São Paulo: Cosac \& Naify, 2002, p. 69

88 A relação entre percepção, expressão e instituição será indicada diversas vezes ao longo do texto, sendo explicitada no final. 
subjetiva. É essa operação originária, capaz de configurar internamente o sentido, que a comparação com uma arte muda $^{89}$ deve fazer transparecer, revelando a dimensão espontaneamente significativa da linguagem. Trata-se, como as análises anteriores indicavam ${ }^{90}$, de um sentido em gênese, inseparável de sua existência concreta, da estruturação própria aos signos que o exprimem: ele não é inteiramente objetivo e nem inteiramente subjetivo porque é gerado pelo movimento interno e auto-regulado da linguagem, abertura e passagem intrínsecas aos termos, sempre aquém de qualquer um deles em particular ${ }^{91}$. Processual, esse sentido implicará, como veremos, zonas de silêncio ou de negatividade no interior de toda expressão, aberturas sem as quais ele não se constituiria: "Em suma, precisamos considerar a fala antes de ser pronunciada, sobre o fundo de silêncio que a precede, que não cessa de acompanhá-la, e sem o qual ela nada diria; mais ainda, precisamos ser sensíveis ao fios de silêncio com que é tramado o tecido da fala." ${ }^{92}$

É essa camada pré-objetiva o território que a pintura - enquanto não dispõe da pretensa exatidão das palavras, da suposta transparência do algoritmo ${ }^{93}$ - está mais apta a revelar do que a própria linguagem, evidenciando o caráter parcialmente autônomo de toda expressão. Este não será, como procuraremos indicar, resultado de indeterminação

89 MAURICE, Merleau-Ponty. A prosa do mundo, São Paulo: Cosac \& Naify, 2002, p. 69

90 Conforme o primeiro capítulo.

91 Essa questão foi indicada no capítulo anterior, principalmente a partir da interpretação que Merleau-Ponty faz da teoria de Saussure.

92 MAURICE, Merleau-Ponty. A prosa do mundo, São Paulo: Cosac \& Naify, 2002, p. 69

93 Como indicado no capítulo anterior, o exemplo do algoritmo é recorrente em Merleau-Ponty, aparecendo como explicitação da tentativa intelectualista de transformar a linguagem em algo inteiramente objetivo, representação de significações puras e determinadas. 
ou de acaso, mas o reverso de um processo auto-orientado, cujo procedimento indireto e aberto escapa aos olhos de um sujeito transcendental e à determinidade de seus objetos. É o que mostra, retomando o exemplo que indicamos no capítulo anterior, a interpretação que Merleau-Ponty faz de uma história sobre Matisse ${ }^{94}$, segundo a qual uma câmera lenta havia registrado o processo criativo do pintor, mostrando sua mão tatear em torno de uma intenção de significar, ensaiar diversos movimentos, e finalmente escolher o único possível para que a configuração se tornasse o que efetivamente viria a $\operatorname{ser}^{95}$. Merleau-Ponty sugere que, por um lado, há escolha, a mão tateia, ensaia e decide ela própria seu movimento; mas, por outro e em consonância com o primeiro, essa criação não é gratuita ou imotivada, ela decide pelo possível em relação a uma certa totalidade já em curso, respondendo a condições internas e a uma lógica implícita que a obra feita oculta e que o próprio artista não coloca explicitamente. Há, assim, coesão e unidade, mas estas permanecem operantes, indissociáveis de sua realização concreta. O funcionamento da expressão, como veremos, implica um sentido e uma consciência não inteiramente determinados, envolvidos sempre em um processo de descentramento e auto-diferenciação: articulando-se por horizontes e referências internas, o ato expressivo opera ultrapassando o que é disponível, diferenciando-se e transcendendo, dotado dessa espécie de negatividade interna que o assegura como criação e não decalque do real ${ }^{96}$ - movimento negativo auto-regulado, ele escapa à condição de objeto ou de representação de algo exterior, pois é por sua dinâmica

94 O exemplo é apresentado tanto na Prosa do mundo (p. 67-69) quanto em A linguagem indireta e as vozes do silêncio (p. 46,47)

95 MAURICE, Merleau-Ponty. A prosa do mundo, São Paulo: Cosac \& Naify, 2002, p. 68

96 Trataremos dessa questão mais adiante. 
própria que o sentido se forma. Como veremos, será esse processo interno, essa ação por descentramento ou metamorfose, que tornará legítimo o paralelo entre linguagem e pintura; especialmente porque em ambas essa negatividade ou essa auto-instituição do sentido não significará uma negação do mundo e de seu solo perceptivo, mas ao contrário será justamente o desdobramento destes, de sua estrutura e de sua síntese espontâneas, revelando a pintura e a linguagem como reconfigurações de algo que as solicita e ultrapassa, de um Logos que elas não engendram e cuja dinâmica prosseguem: "Dos dois lados [na pintura e na linguagem], portanto, é a mesma transmutação, a mesma migração de um sentido esparso na experiência, que abandona a carne onde não conseguia reunirse, que mobiliza em seu proveito instrumentos já investidos e que os emprega de tal forma que enfim se tornem, para ele, o corpo mesmo de que precisava, no momento em que passa à dignidade da significação expressa." ${ }^{\text {97 }}$

Já apontando para o vínculo do movimento expressivo com o mundo e com a percepção ${ }^{98}$, cabe reconhecer que as duas artes operam descentrando ou "deformando" uma experiência, movimentos em que uma "rede de relações" esboçada no mundo é apropriada pelo artista, desinvestida de sua inerência e reorganizada segundo vetores novos 99 : "Seu olhar apropria-se das correspondências, das questões e das respostas que, no mundo, são indicadas apenas secretamente, e sempre abafadas pelo estupor dos objetos, ele os desinveste, os liberta e busca para eles um corpo mais ágil" ${ }^{100}$. O artista ${ }^{97}$ MAURICE, Merleau-Ponty. A prosa do mundo, São Paulo: Cosac \& Naify, 2002, p. 74

98 Como vimos no primeiro capítulo, esse vínculo é reafirmado por diversas maneiras ao longo dos estudos de Merleau-Ponty

99 MAURICE, Merleau-Ponty. A prosa do mundo, São Paulo: Cosac \& Naify, 2002, p. 73

100 Idem, p. 73 
recorre a instrumentos do mundo já disponíveis e significantes, junta-os, manuseia-os, transforma-os para fazê-los induzir o mesmo sentimento de vida que o habita, agora em um corpo menos palpável ${ }^{101}$. Nos dois casos, como explicitaremos ao longo do capítulo, um sentido latente, pré-configurado na percepção ${ }^{102}$, se efetiva e se realiza por sua reconfiguração no gesto expressivo. Reestruturação de uma significação implícita, a expressão escapa tanto à categoria de pura atividade constituinte quanto à de puro objeto constituído: por um lado, ela implica uma ação, transformando ou re-significando; mas por outro, seu ato permanece sempre resposta, operação sobre algo pré-constituído. Os elementos do mundo, agora compostos em um arranjo do qual não participavam antes, não deixam de estar presentes, permanecendo no movimento expressivo que os assume, embora reconfigurados, transformados por esse tipo de negatividade interna que assegura a metamorfose de cada termo: “(...) a tela, as próprias cores, porque foram escolhidas e compostas segundo um certo segredo, deixam de estar, para os nossos olhos, ali onde estão, abrem um buraco no pleno do mundo, tornam-se, como as fontes ou as florestas, o lugar da aparição dos Espíritos, estão ali apenas como o mínimo de matéria de que um sentido precisava para se manifestar." ${ }^{103}$ Transformação e criação no mundo, deformação dele, o ato criativo dá vazão própria aos elementos, faz com que se auto-diferenciem, subvertam-se instituindo um campo e um horizonte novos, espécie de negativo do mundo, internamente formado. O "buraco" que a expressão cava na plenitude do ser em si não

\footnotetext{
101 Idem, p. 74

102 Trataremos mais adiante do modo pelo qual a percepção estrutura a significação.

103 MAURICE, Merleau-Ponty. A prosa do mundo, São Paulo: Cosac \& Naify, 2002, p. 73
} 
significa falta ou negação absoluta, mas abertura que impede o dado de repousar em si e fechar-se na forma da identidade, dilatação interna que o polariza em um sentido e um porvir novos. Como veremos, essa abertura, longe de repor a cisão entre o em si e o para si, entre a atividade niilizadora da consciência e seus objetos, reafirmará a relação entre expressão e percepção, revelando-se presente já na dinâmica perceptiva, operante tanto no sujeito quanto no percebido. É esse negativo da expressão, essa espontaneidade interna ao ato criativo, que procuraremos circunscrever; tentando indicar que, originado na percepção, ele se reafirma tanto na pintura quanto na linguagem, respondendo por um tipo de significação e de síntese que escapa ao modelo intelectualista. 


\section{O Logos do mundo percebido}

A análise de Merleau-Ponty se inicia por um comentário crítico sobre o estudo de Malraux a respeito da história da pintura ${ }^{104}$, recusando sobretudo a separação apontada por ele entre arte clássica e moderna. Partindo da idéia de "expressão criadora", presente no próprio Malraux ${ }^{105}$, Merleau-Ponty procura mostrar que é possível reconhecer uma aproximação entre as duas artes - e, ponto em que nos concentraremos mais, entre linguagem e pintura - já pelo fato delas engendrarem algo novo, recusando-se à categoria de cópia da realidade. À essa criação, contudo, a análise do filósofo acrescentará a restrição de que seu processo permanece motivado, situado dentro de uma dinâmica mais ampla à qual ele responde, distanciando-se portanto da idéia de uma pura constituição. Longe do aparente objetivismo dos clássicos e do suposto subjetivismo dos modernos

104 Como indica Lefort em seu prefácio à Prosa do mundo, Merleau-Ponty recorre principalmente à Psicologia da arte de Malraux, cujo último volume foi publicado em julho de 1950 (A prosa do mundo, São Paulo: Cosac \& Naify, 2002, p. 11)

105 Como veremos, Merleau-Ponty parece fazer uma retomada crítica dos argumentos de Malraux visando explicitar uma filosofia latente ou possível que eles conteriam, baseada na articulação interna entre singular e o geral, o para si e o outro. Será essa filosofia, como procuraremos indicar, que interessará ao filósofo, desdobrando aquilo que seu estudo sobre a percepção e a retomada de Saussure já lhe haviam indicado. 
defendidos no estudo de Malraux ${ }^{106}$, a análise de Merleau-Ponty busca o terreno comum anterior à cisão dos termos, vinculando-os, como veremos, à percepção e ao mundo percebido.

A pintura clássica, em sua interpretação, ainda que se pretendesse uma pura representação do objeto, cópia fiel de uma natureza exterior, não se eximia de um certo trabalho criativo, de uma enformação dos dados. A própria noção de perspectiva se revela uma criação, um modo de formulação culturalmente engendrado, relacionado à construção simbólica de um mundo dominado pelo olhar humano ${ }^{107}$. Sua organização supõe que cada termo do mundo deixe de solicitar para si toda a atenção, cesse de rivalizar com os demais e de coexistir efetivamente com eles. Enquanto no mundo percebido, o olhar, ancorado em uma coisa, sente a solicitação de todas as outras, abre-se ao seu horizonte e à sua pretensão à existência, aqui o ser percebido perde sua dinâmica interna, seu movimento, cristaliza-se na forma de um objeto inteiramente apreensível por uma consciência que o domina: "Enquanto eu tinha a experiência de um mundo de coisas fervilhantes, exclusivas, que não poderia ser abarcado senão por um percurso temporal em que cada ganho é perda ao mesmo tempo, eis que o ser inesgotável se cristaliza numa perspectiva ordenada, em que os longes se resignam a ser somente longínquos (...) em que nada, em suma, retém o olhar e representa o presente - o quadro inteiro está no modo do passado ou da eternidade." $^{108}$

${ }^{106}$ Conforme a leitura que dela faz Merleau-Ponty.

107 MAURICE, Merleau-Ponty. A prosa do mundo, São Paulo: Cosac \& Naify, 2002, p. 77

108 MERLEAU-PONTY, Maurice. A linguagem indireta e as vozes do silêncio, IN: Signos, São Paulo, Martins Fontes, 1991, p. 51 
Enquanto no percebido opera uma temporalidade que impede o Ser de repousar em si, tornando-o simultâneo e aberto, configurado pela passagem de um termo ao outro que diferencia e conserva, a perspectiva constrói um mundo estático, eterno, sem mudanças ou relações, desprovido de qualquer excesso ou metamorfose. Privadas de sua relação interna, postas como identidade, as coisas se fecham em si, e a visão passa a ser a soma de visões monoculares, articulando uma síntese instantânea da qual o olhar dá apenas o esboço ao tentar em vão manter juntas todas as coisas ${ }^{109}$. Diante da simultaneidade conflituosa do percebido, diante de sua temporalidade, a perspectiva recusa o tempo e a contingência, ao compor os objetos segundo uma lei extrínseca, determinando para cada um um lugar inequívoco e absoluto, sem modificação ou passagens possíveis. Ela cria, enfim, um mundo dominado, relacionando-se ao percebido como tentativa de objetivá-lo, de esgotar sua síntese e abertura em uma forma completamente determinada: "A pintura clássica, antes de ser e para ser representação de uma realidade, deve ser primeiro metamorfose do mundo percebido em universo peremptório e racional, e do homem empírico, confuso e incerto, em caráter identificável."110

Em contrapartida, mas também ultrapassando suas premissas mais deliberadas, a pintura moderna, que aparentemente seria a expressão pura da subjetividade $^{111}$, celebração do indivíduo e de sua auto-fruição, acaba por revelar-se atada ao mundo e à generalidade perceptiva. A apresentação de esboços e a tolerância com o

\footnotetext{
109 MAURICE, Merleau-Ponty. A prosa do mundo, São Paulo: Cosac \& Naify, 2002, p. 79

110 Idem, p. 80

111 Segundo a análise de Malraux, trabalhada criticamente por Merleau-Ponty.
} 
inacabado, por exemplo, procedimentos recorrentemente chamados para sustentar a hipótese de que a arte moderna se resumiria ao "prazer de si mesmo e do si mais individual”112, não implicam necessariamente a afirmação do processo subjetivo em detrimento da própria obra. Merleau-Ponty recorre a Baudelaire ${ }^{113}$ para indicar que eles podem ser vistos também como recusa da identificação entre obra feita e obra acabada, a obra se afirmando não no instante em que adquire a completa determinidade do objeto, mas quando seu sentido se torna apreensível ${ }^{114}$, quando o espectador retoma e prossegue o ato que a criou. Ao invés de significar a afirmação de si, a tolerância com o inacabado - na medida em que reconhece e afirma um tipo de unidade cuja formação permanece processual e aberta, detentora de um sentido indireto e implícito - desdobra, como veremos, a síntese já operante no mundo percebido, a articulação dos termos por um processo unitário espontâneo e aberto, confirmando seu solo perceptivo: "Já que a percepção nunca está acabada, já que as nossas perspectivas nos dão para exprimir e pensar um mundo que as engloba, as ultrapassa e anuncia-se por signos fulgurantes como uma palavra ou um arabesco, por que a expressão do mundo seria sujeita à prosa dos sentidos ou do conceito? É preciso que ela seja poesia, isto é, que desperte e reconvoque por inteiro o nosso puro poder de expressar para além das coisas já ditas ou já vistas."115

Antecipando a percepção e o mundo percebido como bases da expressão como base da passagem do singular ao geral, do mesmo ao outro - o inacabamento da ${ }^{112}$ MAURICE, Merleau-Ponty. A prosa do mundo, São Paulo: Cosac \& Naify, 2002, p. 81

${ }^{113}$ Idem, p. 81

${ }^{114}$ Idem, p. 82

115 MERLEAU-PONTY, Maurice. A linguagem indireta e as vozes do silêncio, IN: Signos, São Paulo, Martins Fontes, 1991, p. 53 
obra indica, mais do que um puro sujeito, a retomada ou a continuação do movimento que se faz no próprio mundo percebido, em sua referência espontânea da parte a um todo jamais inteiramente dado: sua dinâmica, como veremos, já é poética, isto é, ela já é expressiva, metamorfose e abertura capazes de reestruturar e resignificar os dados, inserindo-os em uma unidade comum. Procedimento indireto movido por uma lei interna, a percepção e o percebido responderão por uma síntese não objetiva, passagem interna de um termo ao outro pela qual se forma uma significação processual e aberta. Se o a própria estrutura perceptiva é movimento e abertura ${ }^{116}$, o gesto inacabado do artista, ao invés de negá-la, a prossegue, compartilhando do “(...) reconhecimento de uma maneira de comunicar que não passa pela evidência objetiva, de uma significação que não visa um objeto já dado, mas o constitui e o inaugura, e que não é prosaica porque desperta e reconvoca por inteiro nosso poder de exprimir e nosso poder de compreender."117

Desse modo, como explicitaremos ao longo da Tese, e em especial no IV capítulo, a percepção é poética não por repor qualquer modelo objetivista ou construtivista, mas enquanto inscrita na própria reversibilidade existente entre o Ser e o seu devir, entre o Ser e sua expressão, quer dizer, enquanto inscrita na estrutura de um Ser aberto e diacrítico, cuja dinâmica formativa o faz necessariamente diferenciar-se de si, transformando-se e manifestando-se, criando enfim, sem recair nem no determinismo objetivo (pois há mudança) e nem na arbitrariedade subjetiva (pois há transição).

Por ora, retomando nossa análise, o importante é notar que mesmo a arte

${ }_{117}$ Essa questão já foi trabalhada no primeiro capítulo e nós a retomaremos mais adiante. 
moderna, na medida em que se pretende ainda comunicável, não pode pôr em relevo simplesmente a volta ao indivíduo, mas sim a necessidade de se reconhecer um solo comum capaz de assegurar a comunicação entre os homens sem recair na alternativa entre um sujeito e um objeto puros, reconhecimento de uma unidade compartilhada capaz de garantir a simultaneidade e a passagem entre o si e o outro, preservando tanto a singularidade quanto a generalidade da expressão: “(...) trata-se de saber como se pode comunicar sem o amparo de uma natureza preestabelecida e para a qual os sentidos de todos nós se abririam, como pode haver uma comunicação antes da comunicação e, enfim, uma razão antes da razão."118

Como procuraremos mostrar, esse campo geral, aberto, suposto em todo gesto expressivo, capaz de manter um tipo de síntese e de significação distintos do puramente intelectual, não se encontrará mais em uma instância doadora de significações ou em uma realidade em si, mas na percepção e no percebido como formas originais da dinâmica expressiva. Implicando, por isso mesmo, uma outra compreensão da racionalidade: como cabe indicar ao longo do capítulo, essa questão permanece pano de fundo das análises de Merleau-Ponty sobre a linguagem, pois sua noção de expressão enquanto referência interna do singular ao geral, da parte ao todo, responsável pela constituição de um sentido e de uma coerência espontâneos que prescindem da intervenção deliberada de um sujeito - revela uma compreensão da significação e do Logos diversa daquela que os situava em uma pura esfera subjetiva. Unidade espontânea e

\footnotetext{
118 Idem, p. 82, 83
} 
"síntese passiva"119, ela aponta para uma razão que se faz não pela oposição entre sujeito e objeto, mas como uma espécie de descentramento e auto-diferenciação, instituição de um sentido pela dilatação interna que transforma o singular, fazendo-o passar ao outro e ao geral, revelando “(...) de que modo estamos entranhados no universal pelo que temos de mais próprio"120.

Na análise de Merleau-Ponty, essa inter-relação entre a generalidade e a singularidade já aparece no processo significativo sugerido pela análise da pintura, por seu procedimento indireto embasado na percepção; e é essa constatação que the permite afirmar que a análise da relação entre pintura clássica e moderna feita por Malraux, da qual seu próprio estudo parte, não conduz necessariamente a uma filosofia do indivíduo ou da morte, da subjetividade fechada sobre si, podendo apontar também para uma teoria centrada na relação entre o singular e o universal ${ }^{121}$. Parece ser nessa direção que MerleauPonty se apropria das análises do crítico, dando ênfase à sua abordagem da noção de estilo $^{122}$, procurando circunscrevê-la não como expressão do si imediato, mas justamente como mediação entre o geral e o singular, responsável por fazer da obra uma estrutura ao mesmo tempo particular e comunicável; também aqui, esse papel mediador ou pré-objetivo

119 A noção de síntese passiva é, em nossa leitura, uma das bases centrais da Fenomenologia da Percepção, responsável pela descrição da temporalidade e, com ela, de boa parte das análises ali apresentadas, conforme nossa pesquisa de Mestrado (MOURA, Alex de Campos. Liberdade e situação em Merleau-Ponty: uma perspectiva ontológica, São Paulo: Humanitas, 2010).

120 MERLEAU-PONTY, Maurice. Le langage indirect et les voix du silence, IN: Signes, Paris: Gallimard, 2003,p. 84

121 MAURICE, Merleau-Ponty. A linguagem indireta e as vozes do silêncio, IN: Signos, São Paulo: Martins Fontes, 1991, p. 53

122 Segundo o filósofo, Malraux não teria chegado ao cerne da noção de estilo, pois lhe teria escapado o momento em que este opera antes da separação entre homem e mundo. 
se realizará graças ao vínculo que o estilo mantém com a percepção. O estilo, segundo o filósofo, não é identidade ou auto-posição, mas uma espécie de "esquema interior" que se constitui gradualmente na relação do homem com o mundo. Ele não se faz por deliberação, mas por desdobramento espontâneo de um desvio constante, de um modo singular de formulação: “(...) como se cada expressão realizada prescrevesse ao autômato espiritual uma outra tarefa ou ainda fundasse uma instituição da qual jamais terminaríamos de experimentar a eficácia. Este 'esquema interior' sempre mais imperioso a cada quadro (...) para Van Gogh, ele não é legível em suas primeiras obras, nem mesmo em sua vida interior (...) ele é essa vida mesma na medida em que ela saí de sua inerência, cessa de nutrir-se de si mesma, e se torna meio universal de compreender, de ver e de dar a ver - não pois fechada nas trevas do indivíduo mudo, mas difusa em tudo o que ele vê."123

Instituição de uma nova estrutura, o estilo se configura na "superfície da experiência" do sujeito, em sua percepção do mundo, quando um sentido latente encontra os emblemas de que precisava para manifestar-se, tornando-se manejável ${ }^{124}$ para o autor e acessível aos demais. Espécie de sistema de equivalências que orienta a obra de manifestação do artista, ele é o índice universal e concreto da "deformação coerente" pela qual o homem concentra o sentido esparso em sua experiência e o faz existir

${ }^{123}$ MERLEAU-PONTY, Maurice. Le langage indirect et les voix du silence, IN: Signes, Paris: Gallimard, 2003, p. 85: “( $\ldots)$ comme si chaque expression réussie prescrivait à l'automate spirituel une autre tache ou encore fondait une institution d'on il n'aura jamais fini d'éprouver l'efficaité. Ce 'schéma intérieur' toujour plus impérieux à chaque nouveau tableau (...) pour Van Gogh il n'est lisible ni dans ses prèmieres ouvres , ni même dans sa vie intérieur (...) il est cette vie même en tant qu'elle sort de son inherénce, cesse de jouir d'elle même, et devient moyen universel de comprendre, de voir et de donner à voir - non pas donc renfermé aux tréfonds de l'individu muet, mais diffus dans tout ce qu'il voit" [tradução nossa]

${ }^{124}$ MERLEAU-PONTY, Maurice. Signes, Paris: Gallimard, 2003, p. 85 
expressamente, movimento que “(...) retoma e ultrapassa a conformação do mundo que se inicia na percepção"125; nascendo como uma exigência dela ${ }^{126}$. Formando-se quase que à revelia do autor ${ }^{127}$, o estilo participa de uma generalidade que ele próprio não constitui, efetivando uma modulação do todo que se inicia espontaneamente na estrutura perceptiva $^{128}$ : "Ela [a convergência de todos os vetores visíveis e morais do quadro em direção a uma significação X] começa desde que ele percebe - quer dizer, desde que ele reúne ao inacessível pleno das coisas certas concavidades, certas fissuras, figuras e fundos, um alto e um baixo, uma norma e um desvio, desde que certos elementos do mundo assumam valor de dimensões em relação às quais a partir de então reportaremos todo o resto, na linguagem das quais o exprimiremos." ${ }^{129}$ Recuperando a dimensão ontológica da percepção ${ }^{130}$ - questão central, como indicamos no primeiro capítulo, para pensar sua relação com a linguagem e a inserção de ambas no projeto geral de MerleauPonty -, se é ela quem inicia a estilização da experiência, a unificação do diverso em uma estrutura constante, é por ser responsável pela introdução do negativo na plenitude do ser

${ }^{125}$ MERLEAU-PONTY, Maurice. A prosa do mundo, São Paulo: Cosac \& Naify, 2002, p.88

126 MERLEAU-PONTY, Maurice. Signes, Paris: Gallimard, 2003, p. 97

127 Idem, p. 86

128 "Portanto, a percepção já estiliza, isto é, ela afeta todos os elementos de um corpo ou de uma conduta, de um certo desvio comum em relação a uma norma familiar que possuo em meu íntimo" (MERLEAU-PONTY, Maurice. A prosa do mundo, São Paulo: Cosac \& Naify, 2002, p.86)

129 MERLEAU-PONTY, Maurice. Signes, Paris: Gallimard, 2003, p. 88: "Elle commence des qu'il perçoit c'est-à-dire dès qu'il ménage dans l'inacessible plein des choses certaines creux, certaines fissures, des figures et des fonds, um haut et um bas, une norme et une deviation, dès que certaines élémentes du monde prennent valeur de dimmensions sur lesquelles désormais nous reportons tout le reste, dans le langage desquelles nous l'exprimons" [tradução nossa]

130 Essa questão foi trabalhada de modo mais detido no primeiro capítulo. Por essa razão, nesta segunda parte, nós indicaremos ao longo do texto os momentos em que ela aparece, retomando sua discussão de uma maneira menos direta. 
em si, instaurando a diferença no idêntico, formando contornos, relevos, uma configuração singular do ser percebido, respondendo por uma estrutura de ser em que o nada é constitutivo $^{131}$. A dinâmica perceptiva ${ }^{132}$ estabelece as dimensões e os traços fundamentais em relação aos quais o sistema de equivalências de cada artista se forma, configurando-se como estilo. Uma vez instituídas, essas "linhas de força" adquirem certa autonomia, reclamam sua consistência e dinâmica próprias, apoiadas na lógica interna do movimento perceptivo, fazendo com que suas significações não dependam de um ato deliberado: "É suficiente que, no pleno das coisas, introduzamos certos vazios, certas fissuras - e fazemos isso tão logo vivamos - para fazer vir ao mundo precisamente aquilo que the é o mais estranho: um sentido, uma incitação irmã das que nos arrastam para o presente ou o futuro ou o passado, para o ser ou o não ser..."133.

Negatividade inscrita no próprio percebido e em sua dinâmica estrutural, o sentido se revela portador de uma dimensão parcialmente autônoma - agora do lado da percepção e não mais do sujeito, diferença e não constituição -, vindo daí a distância que a análise de Merleau-Ponty reivindica em relação ao O que é a literatura? de Sartre ${ }^{134}$. Se o sentido começa a se formar na estrutura percebida, ele não pode limitar-se, como supõe a teoria sartreana, à "uma bruma de calor" imersa no quadro ou na obra, simples efeito da

131 Essa estrutura ontológica, e esse sentido do negativo, vêm sendo apontados ao longo do capítulo, e serão retomados e explicitados de modo detido no capítulo seguinte.

132 A proximidade entre percepção, expressão e instituição será sugerida ao longo de todo o texto, e explicitada ao final.

133 MERLEAU-PONTY, Maurice. A prosa do mundo, São Paulo: Cosac \& Naify, 2002, p.87

134 A distância entre os dois autores nessa temática, como sugere Parcours deux, se desdobra em várias questões, como por exemplo: na compreensão da prosa e da poesia, no estabelecimento da relação existente entre elas e no lugar ocupado pelo escritor em relação à linguagem. (MERLEAU-PONTY, Maurice. Parcours deux, Verdier, 2000, p. 44, 45). 
composição incapaz de afirmar-se efetivamente. Mais uma vez, estarão no horizonte da divergência entre os dois autores as questões da liberdade e da significação, especialmente na relação que estas mantêm com o mundo percebido.

Já no início de seu texto ${ }^{135}$, Sartre assume o ponto de partida que os textos posteriores de Merleau-Ponty se empenharam em recusar: a separação entre literatura, no caso a prosa ${ }^{136}$, e pintura, afirmando a impossibilidade de se estabelecer entre elas uma aproximação ou mesmo um paralelismo, reconhecendo em cada uma uma dinâmica própria e diversa da outra. Enquanto a prosa faz um uso significativo da palavra, utilizando-a como signo para uma significação específica, a pintura "coisifica" seus elementos, cria uma unidade fechada sobre si dada apenas à contemplação ${ }^{137}$. Segundo Sartre, a diferença entre elas começa a se estabelecer já pelo material de que se servem, pois cores e formas, ao contrário das palavras, são incapazes de remeter para fora de si, de significarem ${ }^{138}$; ainda que disponham de um certo sentido, este acaba por se diluir na materialidade da obra, obscurecido pela impossibilidade da qualidade em exprimir algo que não ela própria ${ }^{139}$.

Para Merleau-Ponty, ao contrário, atado à dinâmica perceptiva, o sentido dispõe como vimos de uma consistência intrínseca, configura-se como uma sintaxe, capaz de exigir e comandar a composição. Ao invés de afirmar uma pura liberdade subjetiva, sua

135 SARTRE, Jean-Paul. O que é a literatura?, São Paulo: Ática, 1993

136 Sartre trabalha com uma distinção clara entre prosa e poesia, afirmando que enquanto a primeira opera com signos, fazendo um uso significativo da palavra (p. 18, 19), a segunda lida com "coisas", forma estruturas que existem por si mesmas, sem constituir-se propriamente em significação (p. 10,11, 18)

137 SARTRE, Jean-Paul. O que é a literatura?, São Paulo: Ática, 1993, p. 10, 18

138 Idem, p. 10, 12

139 Idem, p. 11. Sartre afirma que, ainda que seja impossível afirmar que esse conjunto não possui uma alma, esta acaba submersa,oculta pelo “(...) esforço imenso e vão, sempre interrompido a meio caminho entre o céu e a terra, para exprimir aquilo que sua natureza lhes proíbe exprimir." 
coerência provém do fato dele retirar do percebido suas articulações gerais, pré-formado em uma experiência que não é apenas sua, participável por outrem e anterior às deliberações pessoais; o que o torna mais consistente do que sugere a análise de Sartre, mais geral e menos subjetivo do que um objeto posto por uma consciência. Na perspectiva de Merleau-Ponty, como estamos procurando indicar, não é o sujeito, mas o mundo que ele percebe o fundamento do processo significativo.

Dotado daquela negatividade ou daquela abertura que indicamos acima, cabe ao percebido inaugurar a dinâmica que faz com que um elemento signifique, isto é, com que ele se abra a um sentido mais amplo, exprimindo uma transcendência interna e espontânea: cada fragmento do mundo percebido, segundo ele, ensina, para além de si, "um número infinito de figuras do ser" ${ }^{140}$, responde ao olhar ecoando uma série de variações possíveis e fornecendo ao artista, como solo de toda criação ${ }^{141}$, uma "maneira geral de dizer o ser"142. Cada uma de suas partes visada pela percepção se oferece não de modo objetivo e inteiramente singular, mas como momento ${ }^{143}$ de uma totalidade que a engloba e à qual ela se refere, termo "diacrítico" cuja existência necessariamente remete para além e para fora de si, implicando uma unidade geral que a sustenta. Cada uma delas se afirma como abertura, feita por horizontes que a ultrapassam e a impedem de repousar em si,

140 MERLEAU-PONTY, Maurice. A prosa do mundo, São Paulo: Cosac \& Naify, 2002, p. 89

141 Idem, p. 89

142 (...) on ne demande à la mer - mais elle seule peut l'ensigner, - que sa façon d'interpréter la substance liquide, de l'exhiber, de la composer avec elle-même, en somme une typique des manifestation de l'eua (...) le style qui définira le peintre aux yeux des autres, il lui semble le trouver dans les apparences mêmes et qu'il croit épeler la nature au moment oú il la récree.” (MERLEAU-PONTY, Maurice. Signes, Paris: Gallimard, 2003, p. 90)

143 A relação entre percepção, expressão e temporalidade será indicado ao longo de todo o texto, apontada em diversos momentos, sendo explicitada no final. 
metamorfose e descentramento internos. Vem daí que Merleau-Ponty possa reivindicar, diferindo novamente de Sartre ${ }^{144}$, um “(...) imaginário alojado no mundo”, pois a abertura dos termos, sua transformação e recriação, revela-se dinâmica própria a esse mundo, intrínseca à percepção, e não mais resultado da atividade de um sujeito. O possível - que é sempre o domínio da criação - não é um “(...) surgimento arbitrário, ex nihilo - mas aparecimento lateral de um aparelho de sentido que só aos poucos manifesta seu conteúdo" ${ }^{\text {145 }}$, isto é, formação espontânea e indireta, estabelecendo os contornos privilegiados do campo em que a liberdade se exerce; abertura ou instituição gradual, estruturada pela dilatação interna do mundo percebido. Cabe a ele, e não à subjetividade, sustentar esse sentido capaz de formar-se espontaneamente: é na relação da parte ao todo, relação presente e estruturante do mundo percebido - responsável por fazer de cada elemento uma abertura e uma referência aos outros - , que se encontra a matriz de toda expressão, de toda referência do atual ao possível, da passagem do presente aos seus horizontes. Não há pura gratuidade na criação, afirmação de uma liberdade completa como pretendia Sartre, porque o "outro mundo" que o artista desvela e cria é ainda, em certo sentido, o mesmo que ele percebe: "Um outro mundo - entendamos: o mesmo que o pintor vê, apenas liberado do peso sem nome que o conserva no fundo e o mantém no equívoco. Como o pintor ou o poeta diriam outra coisa que seu encontro com o mundo?"146

144 Para Sartre, o imaginário pressupõe um movimento de negação do em si, uma niilização responsável por ultrapassar o dado (Conforme, por exemplo, O Ser e o Nada, Rio de Janeiro: Vozes, 1999).

${ }^{145}$ Idem, p. 69

${ }^{146}$ MERLEAU-PONTY, Maurice. Signes, Paris: Gallimard, 2003, p. 91: "Un autre monde - entendons: le même que le peintre voit, seulement libere du poids sans nom qui le retenait en arrière et le mantenait dans l'équivoque. Comment le peintre ou le poète diraient-ils autre chose que leur rencontre avec le monde?" [tradução nossa] 
Desse modo, a "matéria" de todo gesto expressivo, o mundo, deixa de ser um dado objetivo, ser cristalizado e determinado, para revelar-se como estrutura expressiva originária, instituição da passagem interna entre o singular e o geral. Contra a idéia de uma subjetividade constituinte e contra a simétrica idéia de uma aglomeração fortuita de fatos, a expressão se apóia na dinâmica própria ao mundo para configurar a significação: sendo ele próprio abertura, transcendência que faz de cada elemento referência a uma unidade ou a um sentido mais gerais, ele assegura que toda singularidade, na medida em que se relaciona de algum modo a ele, integre-se em uma lógica mais ampla, que cada termo ou ação novos sejam imediatamente inseridos em uma estrutura generalizada: "O que eles [os modernos] puseram no lugar de uma inspeção do espírito que descobriria a textura das coisas, não é o caos, é a lógica alusiva do mundo."147

Entre o artista e seu mundo, longe de uma relação de correspondência ou de adequação, o que se estabelece é a partilha de um processo comum, retomada do movimento interno em que se forma a unidade própria ao percebido. O que o pintor cria pode ser compreendido como um desdobramento do mundo porque é dele que ele retira a forma geral de toda expressão, da passagem entre os elementos que assegura o sentido e a coerência do todo, unidade processual e lógica encarnada sustentando a coesão entre seus diferentes momentos. Por esse vínculo, o trabalho expressivo mantém-se orientado, articulado de modo coerente graças à sua ligação com uma estrutura da qual participa, mas que ele próprio não constitui, configurando-se como momento, antecipação e retomada,

147 MERLEAU-PONTY, Maurice. A prosa do mundo, São Paulo: Cosac \& Naify, 2002, p. 91 
dentro de um fluxo geral que o modula e o impede de determinar-se completamente, fazendo-o parte de uma unidade que recusa a identidade absoluta do $\mathrm{si}^{148}$. Isso não significa, porém, que a expressão singular, o sujeito, encontre-se limitada por uma determinação exterior, e a diferença assumida por Merleau-Ponty em relação a Sartre não equivale ao abandono da liberdade em nome da afirmação de uma causalidade extrínseca à expressão ${ }^{149}$. Ao contrário, é preciso considerar que a relação entre a parte e o todo presente em sua análise, como ocorria desde o início de seu estudo sobre a linguagem ${ }^{150}$, se faz preservando a especificidade dos termos, evitando a redução de um ao outro que recairia na alternativa entre o significado e a facticidade, o subjetivo e o objetivo. Autores como Dillon ${ }^{151}$ e Thierry ${ }^{152}$, em encaminhamentos diferentes, apontam também para o fato de que há na teoria da linguagem de Merleau-Ponty uma relação entre a particular e o geral que busca uma reciprocidade entre os termos, ao invés da redução de um ao outro. 0 primeiro insiste na relação de Fundierung ${ }^{153}$, já presente no início da obra do filósofo, e que implica um vinculo interno e constitutivo entre o termo fundante e o termo fundado; o segundo, dá ênfase ao fato da dinâmica expressiva estabelecer um movimento em que o

148 "Mas esse caminhar de cego é não obstante demarcado por índices: ele jamais cria no vazio, ex nihilo. Sempre se trata de levar mais longe o sulco já aberto no mundo como ele o vê, em suas obras precedentes ou nas do passado, de retomar e de generalizar essa inflexão que apareceu no canto de um quadro anterior, de converter em instituição um costume já instalado sem que o pintor possa nunca dizer, porque isso não tem sentido, o que é dele e o que é das coisas, o que tomou de seus predecessores e o que é seu." (MAURICE, Merleau-Ponty. A prosa do mundo, São Paulo: Cosac \& Naify, 2002, p. 94)

149 Como sugere uma linha interpretativa, da qual trataremos mais adiante.

${ }^{150}$ Conforme indicado na primeira parte, especialmente pela maneira com que Merleau-Ponty retoma Saussure.

${ }^{151}$ DILLON, M.C. Merleau-Ponty's Ontology, Northwestern University Press, 1997

152 THIERRY, YVES. Du corps parlant, Le langage chez Merleau-Ponty, OUSIA, 1987

153 DILLON, M.C. Merleau-Ponty's Ontology, Northwestern University Press, 1997, p. 197 
gesto individual, sem deixar de afirmar-se, adquire uma dimensão universal e comunicável ${ }^{154}$.

Em nossa leitura, essa participação do termo singular em uma estrutura que o ultrapassa não desfaz sua autonomia, pois ela implica a reafirmação de um movimento livre e criador em cada gesto expressivo: "Cada ato linguístico parcial, como parte de um todo e ato comum da língua, não se limita a consumir-lhe o poder, ele o recria porque nos faz verificar, na evidência do sentido dado e recebido, a capacidade que os sujeitos falantes possuem de ultrapassar os signos em direção ao sentido, do qual aquilo que chamamos língua não é, afinal, senão o resultado visível e o registro."155 Se a "essência" ou o "segredo" de uma obra permanece inseparável de sua existência em um mundo que a solicita e enforma; se é sempre na figura das coisas que o artista reencontra o mesmo apelo, a mesma direção que seu trabalho prossegue ou transforma, isso não significa que sua criação se reduza a um efeito dos fatos sofridos, das determinações exteriores impostas, e sim que há sempre um elo entre aquilo que é vivido e aquilo que é expresso, que a transcendência de cada gesto expressivo encontra-se necessariamente vinculada a um movimento mais amplo. O mundo ao qual o sujeito se mantém atado não the determina, privando-o de sua liberdade, porque ele não é da ordem do objeto, não se oferece de forma única, traçando apenas em pontilhado um caminho que a criação pode seguir ou alterar, abertura de possibilidades que implica uma transcendência que as efetivará; instauração de um processo que se faz como diferença e transformação, o mundo permanece estrutura

${ }^{154}$ THIERRY, YVES. Du corps parlant, Le langage chez Merleau-Ponty, OUSIA, 1987, p. 80

${ }^{155}$ MERLEAU-PONTY, Maurice. A prosa do mundo, São Paulo: Cosac \& Naify, 2002, p. 
geral do movimento expressivo, dinâmica aberta que carece da singularidade para realizarse em uma forma concreta.

Como indicamos no capítulo anterior, afirmar a ecceidade do mundo não equivale a supor uma determinação objetiva que agiria sobre o sujeito, negar a autonomia e a liberdade humana, pois o que sua pré-constituição instaura é apenas a forma geral de um processo infinito de mudança e de afastamento de si, linhas gerais de um devir necessariamente não idêntico. Nesse sentido, o singular não é uma simples ocasião para que uma determinidade objetiva se realizasse, mas a resposta solicitada por um mundo que se oferece sempre como abertura e transição. Como explicitaremos ao longo da Tese, configurando um horizonte que dilata o dado e o remete a algo diverso de si, à sua própria mudança, o que o mundo exige é precisamente o novo e a criação. Incapaz, portanto, de exigir esta ou aquela resposta, o que ele exige é que haja respostas e que essas sejam justamente diferentes da totalidade já dada. Assim, ao afirmar a ecceidade do sentido e o vínculo entre expressão e percepção, o que a ontologia merleau-pontyana recusa não é a liberdade, mas sim sua compreensão como absoluta ou imotiva, inscrevendo-a agora na estrutura mesma de um Ser aberto e diacrítico, que necessariamente pede a mudança e o devir.

Dentro dessa perspectiva, a obra não é um efeito, mas sempre uma resposta ao mundo, uma ação que reconfigura a experiência: “(...) se Leonardo é algo mais do que a vítima de uma infância infeliz, não é que ele tenha um pé no além, é que, de tudo o que viveu, ele conseguiu fazer um meio de interpretar o mundo - não é que ele não tivesse 
corpo ou visão, é que sua situação corporal ou vital foi por ele constituída em linguagem."156

Longe de obstruir a liberdade, trata-se para Merleau-Ponty apenas de considerar que ela se faz recorrendo a um processo e a um conjunto de possíveis que se oferecem no próprio mundo, já latentes em sua percepção; formas privilegiadas, mas que permanecem como horizontes e aberturas, incapazes de determinar o ato que as assumirá. Julgamos, assim, ser possível divergir de uma linha de comentadores que vêem no recurso de Merleau-Ponty à percepção um movimento que dissolve a liberdade do sujeito, questão bastante discutida entre seus intérpretes. Delcó ${ }^{157}$ e Haar $^{158}$, por exemplo, reencontram, por caminhos diversos, uma crítica comum segundo a qual o percebido, ao oferecer-se como matriz da expressão, passaria a determiná-la, privando-a de sua dimensão criativa. Entretanto, outros autores, como Madison $^{159}$, reconhecem a percepção não como determinante da obra, e sim como inseparável do gesto livre e criativo do autor; no caso, recorrendo à noção de estilo, como ação que não se realiza por um processo consciente, mas pela imbricação entre homem e mundo ${ }^{160}$.

Em nossa perspectiva, consideramos que é preciso levar em conta que a

156 A relação entre liberdade e situação, segundo nossa interpretação, é um dos temas centrais da filosofia de Merleau-Ponty, presente desde o início de sua obra, conforme nossa pesquisa de Mestrado (MOURA, Alex de Campos. Liberdade e situação em Merleau-Ponty: uma perspectiva ontológica, São Paulo: Humanitas, 2010). Ela já era basilar em outro comentário que o filósofo fazia sobre Leonardo, em A Dúvida de Cézanne (MERLEAU-PONTY, Maurice. Sens et non sens, Paris: Gallimard, 1997), no qual eram mobilizados conjuntamente os recursos da poesia (Valery) e da psicanálise (Freud) para mostrar que não há liberdade sem situação e que toda ação se afirma como uma reestruturação do mundo.

157 DELCÒ, Alessandro. Merleau-Ponty et léxpérience de la création, PUF, 2005, p. 141

158 HAAR, Michel. Peinture, perception, affectivité, IN: Merleau-ponty, phénoménologie et experiences (orgs: TASSIN, Marc; RICHIR, Etienne), Grenoble, 1992

159 MADISON,G.B. The phenomenology of Merleau-Ponty, Ohio University Press, 1981

${ }^{160}$ Idem, p. 86, 87 
percepção, para Merleau-Ponty, não se oferece como objeto, que o percebido não é uma realidade dada com a qual o sujeito se confrontaria; ao contrário, como estamos procurando mostrar, percebido e percepção se oferecem como estruturas abertas e processuais, matrizes do movimento expressivo e do Logos espontâneo que, ao configurarem o sujeito, longe de o determinarem, o tornam necessariamente participativo de um processo de significação, necessariamente criador de sentidos, formado por transcendência e mudança. O percebido não é um dado capaz de determinar o homem, mas uma abertura de possibilidades. Em nossa leitura, a expressão e a liberdade se afirmam para Merleau-Ponty não como alternativa ao mundo e à percepção, mas como processos inseparáveis deles, ação e criação que retiram da estrutura perceptiva de seu mundo o horizonte de possíveis sem o qual não poderiam se realizar.

A liberdade se faz no momento em que o que foi dado ao artista viver se organiza em torno de certas linhas de força, se estrutura dentro de uma unidade significativa que indica sua relação fundamental com o mundo ${ }^{161}$; no momento em que os fatos se organizam em um desvio singular, assumidos por um movimento que os insere em uma unidade comum; quando, enfim, um gesto singular vem descentrar e "estilizar" a facticidade, dar forma aos dados e instituir um campo novo, uma articulação diversa das demais. Assim, se não é inteiramente dependente do sujeito, se recorre à estrutura perceptiva para configurar-se, nem por isso esse movimento significativo se esgota no mundo percebido, e o vínculo proposto por Merleau-Ponty entre percepção e expressão não

161 MERLEAU-PONTY, Maurice. A prosa do mundo, São Paulo: Cosac \& Naify, 2002, p.84 
recai, necessariamente, na exterioridade e na afirmação de um em detrimento do outro. Ao contrário, entre eles, entre a ordem dos fatos e a da criação, o que se configura é um mesmo movimento, ora passivo, ora ativo, ora latente, ora manifesto; a significação se fazendo como subversão gradual do dado, realização livre de uma possibilidade nele próprio resguardada:

“1) A metamorfose (esta ou, em geral, a do passado pelo presente, do mundo pela pintura, do passado do pintor pelo seu presente) (...) só é possível porque o dado era pintura, porque há um Logos do mundo sensível (e do mundo social e da história humana). - A ilusão analítica de Malraux e o fenômeno do mundo cultural. O único mistério está aí: o do Nachvollzug. Ele repousa sobre o mistério do mundo natural e de seu Logos. O homem ultrapassa o mundo sem se dar conta disso e como que naturalmente."162

A mesma dinâmica significativa se revela, enfim, na facticidade e no sentido, operante tanto no dado quanto na criação, difusa na generalidade do percebido e na singularidade do gesto livre que o retoma. O mundo - na medida em que se dá a perceber se oferece como presença irrecusável dotada de uma transcendência interna, de um excesso sobre si mesma. Alargado, capaz de distender-se e diferenciar-se, ele não é mais um território oposto ao imaginário e à criação; ao contrário, cabe a ele sustentar o movimento que impede o singular de repousar em si, unificando o diverso pela relação interna que estabelece entre a parte e o todo. Se o "dado já era pintura" é porque ele já era mais que si próprio, já se organizava dentro de um conjunto significativo, referindo-se aos

${ }^{162}$ Idem, p. 96 
demais, articulando-se e solicitando a metamorfose que viria confirmá-lo como momento de um totalidade mais ampla. Em uma palavra, ele já era expressão. É por isso que todo ato expressivo, sem abdicar de sua liberdade, encerra necessariamente um tipo de espontaneidade que não se refere ao sujeito, e sim à sua participação nessa lógica operante no mundo sensível, dinâmica expressiva originária responsável pelo ultrapassamento interno característico do processo significativo: “(..) o poder de transcendência da fala e da percepção resulta precisamente da própria organização delas. A passagem à Bedeutung não é um salto no 'espiritual' (...) a significação e o signo são da ordem do perceptivo, não da ordem do Espírito absoluto. Sim, há uma questão de saber como os primeiros signos se tornaram capazes de sedimentação e de todo um [?] de cultura, e há uma questão de saber como pensar a presumida consumação da linguagem na não-linguagem, no pensamento. Mas esses dois fatos não são senão o fato mesmo da percepção e da racionalidade, do logos do mundo estético. Exigir uma explicação é [?] de obscurum per obscurius." 163

Explicitando o vínculo interno entre percepção e linguagem, cabe reconhecer que a fala, como todo movimento expressivo, participa da racionalidade e do Logos do mundo instituídos pela dinâmica perceptiva. Compreendidas sob esse prisma, a sedimentação e a transcendência, a existência singular de cada parte e a unidade comum que as engloba, deixam de ser movimentos antagônicos, cuja relação se explicaria pela atividade externa de uma consciência, para se apresentarem como momentos interligados

${ }^{163}$ MERLEAU-PONTY, Maurice. A prosa do mundo, São Paulo: Cosac \& Naify, 2002, p.60 
em um processo único de significação. Em nossa leitura, essa abertura a uma significação que não se forma subjetivamente é um dos principais eixos que sustenta a aproximação entre pintura e linguagem pretendida por Merleau-Ponty. Ambas revelam-se como desdobramentos dessa unificação que as enforma e à qual elas respondem: "Contra a idéia de uma ação da linguagem que [seja?] verdadeiramente nossa (...) devemos realmente colocar em suspenso a linguagem 'significante' para deixar aparecer a linguagem 'pura', e a linguagem é pintura assim como a pintura é linguagem. Precisamos nos desfazer da ilusão de ter possuído dizendo"164. Recusando o sentido como objeto posto, explícito, que nada deveria ao mundo, as diferentes formas de expressão se encontram por essa espécie de passividade intrínseca ${ }^{165}$, prolongamento de uma unificação já em curso e de um procedimento indireto que não possui seu objeto, mas o desdobra, centrando-se na lógica tácita do percebido.

Sendo assim, o recurso à pintura, a redução operada pela comparação com uma arte muda, se precisa: cabe a ele confirmar aquilo que já a linguística de Saussure havia revelado, a presença na linguagem de um tipo de significação - ou de $\operatorname{Ser}^{166}$ - que se faz pela lógica interna aos signos, pelo arranjo espontâneo das partes, capaz de formar uma conjunto que se furta à completa positividade do objeto; sentido perceptivo e síntese

\footnotetext{
164 Idem, p. 96

165 Segundo nossa perspectiva, a questão da passividade é uma das marcas distintivas da reflexão de MerleauPonty, central já na Fenomenologia da Percepção, conforme nossa pesquisa de Mestrado (MOURA, Alex de Campos. Liberdade e situação em Merleau-Ponty: uma perspectiva ontológica, São Paulo: Humanitas, 2010). Esse tema é explicitamente trabalhado pelo filósofo em seus cursos no Collège de France de 1954 e 1955, dos quais nos ocuparemos mais detidamente no próximo capítulo, quando tratarmos da passagem dos textos sobre a linguagem para as últimas obras.

${ }^{166}$ Conforme indicado na primeira parte.
} 
operante que não se deixam apreender inteiramente ${ }^{167}$. Um romance, dirá Merleau-Ponty, exprime tacitamente, como um quadro ${ }^{168}$. Ele não se oferece na forma de um conjunto de enunciados, significação direta exposta sem qualquer resíduo, mas como inauguração de um estilo, sentido oblíquo ou latente que é primeiramente percebido como desvio no universo cultural: "Do mesmo modo que o da pintura, o sentido próprio da obra de arte não é perceptível, de início, senão como uma deformação coerente imposta ao visível. E jamais o será a não ser assim (...) significação inesgotável de que o romance se viu revestido quando veio descentrar, distender, solicitar para um novo sentido nossa imago do mundo e as dimensões da nossa experiência."169

De maneira similar à pintura, o romance exprime descentrando uma experiência, singularizando e transformando uma generalidade que ele não contém, significação mais ampla que seu gesto recria e manifesta. Como o filósofo mostra através do exemplo de Balzac ${ }^{170}$, sua força expressiva não se encontra em suas teses objetivas, mas em sua maneira de tornar visível um estado de coisas ou uma configuração do real, rearranjo do dado que busca manifestar algo que nele permanece como possibilidade e latência. Nem existência objetiva ("superexistência"), pois atada a uma síntese aberta, e nem arbitrária ou ficcional, também porque atada a essa síntese, a linguagem, como a pintura, se coloca no intermeio entre os dois campos, "existência sublimada". Fora do

167 MERLEAU-PONTY, Maurice. A prosa do mundo, São Paulo: Cosac \& Naify, 2002, p.116

168 MERLEAU-PONTY. Maurice. A Linguagem indireta e as vozes do silêncio, IN: Signos, São Paulo:Martins Fontes, 1991, p. 80

169 MERLEAU-PONTY, Maurice. A prosa do mundo, São Paulo: Cosac \& Naify, 2002, p.120

170 MERLEAU-PONTY. Maurice. A Linguagem indireta e as vozes do silêncio, IN: Signos, São Paulo:Martins Fontes, 1991, p. 81 
espaço cindido entre os termos, as duas modalidades passam a dispor de uma verdade que não é mais semelhança com o real, adequação a um objeto ${ }^{171}$ - já que seu próprio pressuposto, a exterioridade entre o representante e o representado, foi posto em questão , mas coerência interna de um processo cuja organização provém da estrutura referencial de suas partes. Unidade do movimento que configura o conjunto e garante à cada termo um respaldo no todo, a verdade retira da percepção a matriz de uma dinâmica que não se contenta em reproduzir o dado ou em constituí-lo: "Não aceitam uma verdade que seja a semelhança entre a pintura e o mundo. Admitiriam a ideia de uma verdade que fosse a coesão de uma pintura consigo mesma, a presença nela de um princípio único que destinasse a cada meio de expressão um certo valor de emprego. Ora, quando uma pincelada substitui a reconstituição em princípio completa das aperências para nos introduzir na lã ou na carne, o que substitui o objeto não é o sujeito, é a lógica alusiva do mundo percebido."172

Explicitando o que estamos procurando indicar ao longo do texto, o que aproxima pintura e linguagem é o vínculo que elas mantêm com o mundo percebido, lógica alusiva e instituição originária, feito da simultaneidade entre unidade e abertura, apresentando-se ao filósofo como alternativa aos marcos da ontologia clássica. Ao gesto expressivo, seja à palavra ou ao quadro, cabe não reproduzir uma realidade, mas

171 “A pintura moderna, como o pensamento moderno em geral, obriga-nos a admitir uma verdade que não se assemelhe às coisas, que não tenha modelo exterior, nem instrumentos de expressão predetestinados, e que seja contudo verdade" (MERLEAU-PONTY, Maurice. A linguagem indireta e as vozes do silêncio, IN: Signos, São Paulo, Martins Fontes, 1991, p. 59)

172 MERLEAU-PONTY, Maurice. A linguagem indireta e as vozes do silêncio, IN: Signos, São Paulo, Martins Fontes, 1991, p. 58 
prossegui-la, refazendo, por sua conta, o movimento interno e aberto em que ela se forma. Se a expressão não é constituição, mas desdobramento do significado, sua verdade passa a se situar na coesão com que retoma (por continuidade ou diferença) o movimento geral do percebido, a articulação das partes que assegura a densidade do significado. É esse laço com o percebido, como indicamos ao tratar da liberdade do artista, que faz com que a reordenação do mundo prosaico $^{173}$ realizada pela pintura e pela linguagem, seja ainda formação de uma outra ordem ${ }^{174}$; não uma negatividade que romperia absolutamente com o dado, mas uma modulação orientada pelo próprio objeto, espécie de negação motivada ou dirigida que desfaz os laços comuns das coisas na tentativa de encontrar a estrutura mais geral de que participam, dispondo de uma verdade que se faz por retomada e recriação concomitantes: "A significação ordinária da janela, do painel de cachimbos, da parede, não é negada, já que é sempre do mundo que se fala se se quer ser entendido, mas pelo menos reintegrada numa significação mais originária, mais ampla, da qual é retirada (...) Ou melhor - pois a percepção é sempre ação - a ação aqui torna-se praxis, isto é, ela se recusa às abstrações do útil e não quer sacrificar os meios ao fim, a aparência à realidade. Tudo conta a partir de então, e importa menos o uso dos objetos que sua capacidade de compor em conjunto, na sua textura mais íntima, um emblema válido do mundo ao qual somos confrontados." ${ }^{175}$

A percepção não é decalque de um real externo porque ela forma, em sua

\footnotetext{
173 MAURICE, Merleau-Ponty. A prosa do mundo, São Paulo: Cosac \& Naify, 2002, p. 90

174 Idem, p. 90

175 Idem, p.91
} 
estrutura mesma, uma unidade significativa, dotada de uma capacidade interna de composição que recria o dado, transformando-o e realizando-o. Distância interna, unidade cuja coerência provém de sua abertura, o movimento expressivo iniciado no percebido se desdobra tanto na pintura quanto na linguagem, constituindo, segundo nossa leitura, um dos principais pontos de aproximação entre as duas. 
3. História, corpo e tempo

Como veremos agora, referência interna da parte ao todo, saída de si guiada por uma lógica processual, caberá ao movimento perceptivo-expressivo responder por uma articulação entre os momentos (da existência e da cultura ${ }^{176}$ ) que abdica do recurso a um termo exterior, matriz de uma historicidade que se faz pela estrutura aberta dos fatos e pela "afinidade" constitutiva das singularidades, ajudando-nos a confirmar o vínculo entre percepção e expressão.

Explicitando sua discussão sobre o tema ${ }^{177}$, Merleau-Ponty recorre ao exemplo de Vermeer para mostrar que o que configura uma obra diante da história da cultura - o que faz um verdadeiro "Vermeer" - não é um conjunto de características empíricas objetivas, sua adequação a uma norma ou a comprovação documental de sua autenticidade. Em relação à história, "um Vermeer" significa a realização de uma estrutura

${ }^{176}$ Conforme a relação entre "mundo sensível" e "mundo da cultura", indicada no capítulo anterior.

177 Como a grande maioria dos temas em Merleau-Ponty, a questão da história não é apresentada de modo isolado, como uma aparição súbita, mas já envolvida na análise das outras questões, entrevista, retomada e implicada nas demais proposições do filósofo. 
ou de uma linguagem singular, afirmação de um desvio constante e de uma forma recorrente de diferenciar-se recriando os dados que se apresentam ${ }^{178}$. Portanto não a formação de um sentido como realidade objetiva destacável, essência pura desvinculada de qualquer contexto, mas modulação responsável por singularizar a generalidade que lhe configura, estilização de um todo que o ultrapassa e ao qual ele dá uma forma particular. A significação de uma obra se configura como inauguração de um nova maneira de tratar o mundo e de percebê-lo, instituição ${ }^{179}$ de uma dimensão até então desconhecida, abertura de uma estrutura que tende a generalizar, não se esgotando no gesto singular que a criou; mais do que uma realidade empírica, uma grande obra inaugura um horizonte.

É possível, então, segundo Merleau-Ponty, reconhecer duas historicidades ${ }^{180}$, uma irônica, feita de oposições e contra-sensos, em que cada tempo luta com os demais como estrangeiros, em que o sentido se afirma como desmembramento, ignorância e exterioridade; e uma outra, formada a partir do modelo expressivo, baseada no que nos liga à alteridade, feita da relação orgânica entre abertura e diferenciação, entre o novo e o passado. Ela se faz, como veremos, pela vida que o passado continua a levar no ato que o retoma e o reprojeta no porvir, pela troca contínua existente entre eles ${ }^{181}$. Cada obra e cada

178 “(...) isto é, ela [?] observa o sistema de equivalências particular que faz que todos os momentos do quadro, como cem ponteiros em cem quadrantes, indiquem o mesmo e insubstituível desvio" (MERLEAU-PONTY, Maurice. A prosa do mundo, São Paulo: Cosac \& Naify, 2002, p.85)

179 "Vermeer porque era um grande pintor tornou-se algo como uma instituição ou uma entidade, e assim como a história tem por papel descobrir o sentido do Parlamento ou da Revolução Francesa (...) também a história da pintura tem por encargo definir, através da figura empírica das telas ditas de Vermeer, uma essência, uma estrutura, um estilo, um sentido de Vermeer contra o qual não podem prevalecer, se houver, os detalhes discordantes arrancados de seu pincel pela fadiga, pela circunstância ou pelo costume (MERLEAU-PONTY, Maurice. A prosa do mundo, São Paulo: Cosac \& Naify, 2002, p.98)

180 MERLEAU-PONTY, Maurice. A prosa do mundo, São Paulo: Cosac \& Naify, 2002, p. 99

181 Idem, p. 99 
artista, como fala e estilo, abertura de um campo e modulação de uma generalidade, já se difundem nos demais, já se reúnem a eles como passado ou como porvir, retomada ou antecipação de suas realizações e de seus equívocos. Apontando para o sentido temporal da dinâmica expressiva revelada pela arte, essa historicidade é aquela que se desdobra graças à síntese interna aos momentos, à coesão que estabelecem entre si através do movimento que diferencia e retoma simultaneamente. A unidade da história, assim, não demanda uma razão que trabalharia nas costas dos artistas, como um "Espírito da Pintura" que apenas se confirmaria em cada uma de suas aparições ${ }^{182}$; esse recurso só é necessário como correlato do individualismo que isola cada um dos termos envolvidos, considerandoos como acontecimentos absolutamente fechados que demandariam uma síntese exterior para relacionar-se. É contra essa unidade externa que o modelo expressivo proposto por Merleau-Ponty se coloca, indo buscar uma articulação interna ao diverso.

Nesse movimento, é central o recurso do filósofo ao corpo, entendido como sujeito da percepção e como sendo, ele próprio, uma estrutura expressiva ${ }^{183}$, correlata dessa unidade que não se deixa reduzir ao produto de uma consciência constituinte ${ }^{184}$, pois será nele que se iniciará a configuração unitária da experiência, a estruturação temporal do múltiplo $^{185}$. Partindo do exemplo de algumas miniaturas e da escrita, em que é possível

${ }^{182}$ MERLEAU-PONTY, Maurice. A linguagem indireta e as vozes do silêncio, IN: Signos, São Paulo, Martins Fontes, 1991, p. 68

183 A noção do corpo como sujeito da percepção e como estrutura expressiva é apresentada e desenvolvida especialmente na Fenomenologia da Percepção.

${ }^{184}$ Como indicamos em nossa pesquisa de Mestrado (MOURA, Alex de Campos. Liberdade e situação em Merleau-Ponty: uma perspectiva ontológica, São Paulo: Humanitas, 2010), não julgamos que o recurso ao corpo implique o abandono da dimensão da consciência, mas sim de uma certa compreensão da operação significativa.

185 “E o primeiro desenho na parede das cavernas só fundava uma tradição porque recolhia uma outra: a da 
reconhecer a presença de um estilo constante em espaços nos quais o artista não opera conscientemente, Merleau-Ponty mostra que o corpo mantém uma capacidade geral e constante de formulação, imprimindo seu monograma em situações que ultrapassam o conhecimento explícito do sujeito. Fora do domínio da objetividade, o corpo é capaz de instaurar uma unidade comum entre seus gestos, fazendo com que cada ato singular encontre-se integrado e ancorado na estrutura geral do conjunto. $\mathrm{O}$ "milagre expressivo", a "transgressão orientada" ${ }^{186}$ que fazem de cada termo uma referência aos demais, revelamse pois naturais ao homem: eles começam com a existência encarnada, com o corpo percipiente efetuando a passagem que lança o singular no geral, configurando uma unidade: “(...) aqui o espírito do mundo somos nós, assim que sabemos nos mover, tão logo saibamos olhar. Esses atos simples já encerram todo o mistério da ação expressiva. Pois movo meu corpo mesmo sem saber que músculos, que trajetos nervosos devem intervir, e onde seria preciso buscar os instrumentos dessa ação (...) Olho onde está o objetivo, sou aspirado por ele, e toda a máquina do corpo faz o que é preciso para que eu chegue lá." ${ }^{187}$ Não é a consciência ou o corpo como entidades objetivas que dão início à estruturação de uma totalidade, mas o corpo como sujeito da percepção, responsável por configurar a si e aos dados visando-os como pólo único de seus atos e de seu movimento ${ }^{188}$, assumindo

percepção. A quase eternidade da arte se confunde com a quase eternidade da existência encarnada, e temos em nosso corpo, antes de qualquer iniciação à arte, a primeira experiência do corpo impalpável da história" (MERLEAU-PONTY, Maurice. A prosa do mundo, São Paulo: Cosac \& Naify, 2002, p.111)

186 MERLEAU-PONTY. Maurice. Sobre a fenomenologia da linguagem, IN: Signos, São Paulo: Martins Fontes, 1996, p. 100

187 MERLEAU-PONTY, Maurice. A prosa do mundo, São Paulo: Cosac \& Naify, 2002, p.105

188 Bonan já insistia na importância da motricidade como base do movimento significativo, intencionalidade originária (BONAN, Ronald. Merleau-Ponty de la perception à l'action, Université de Provence, 2005). 
dinamicamente o sentido latente que eles esboçam. Ao perceber, o corpo realiza um tipo de "acoplagem" com o percebido, por meio da qual eles se unificam reciprocamente, o corpo enquanto projeto e o percebido enquanto meta e solicitação. Estilização do mundo dentro de uma forma singular, conformação dos dados e dos gestos dispersos em um sentido comum, a percepção realizada pelo corpo inaugura a estruturação da experiência:

"Toda percepção e toda ação que a supõe, em suma, todo uso de nosso corpo já é expressão primordial, ou seja, não o trabalho secundário e derivado que substitui o exprimido por signos dados noutra parte com seu sentido e sua regra de emprego, mas a operação que primeiramente constitui os signos como signos, faz habitar neles o exprimido - não sob a condição de alguma convenção prévia, mas pela eloqüência de seu próprio arranjo e de sua configuração -, implanta um sentido naquilo que não o tinha, e que portanto, longe de esgotar-se no instante em que ocorreu, abre um campo, inaugura uma ordem, funda uma instituição ou uma tradição..."189

Reafirmando o vínculo entre percepção e expressão, a referência de Merleau-Ponty ao corpo confirma que todo movimento perceptivo já implica a configuração de uma unidade, realiza a conformação de um estilo, instaurando e exprimindo um sentido constante que configura o parcial, inserindo-o em uma direção mais ampla. Assim como cada gesto corporal só se compreende e se constitui referindo-se a uma totalidade que o abarca, estabelecendo uma relação sincrônica com o mundo ${ }^{190}$, também o signo só se

189 MERLEAU-PONTY, Maurice. A prosa do mundo, São Paulo: Cosac \& Naify, 2002, p.106

190 MERLEAU-PONTY. Maurice. Sobre a fenomenologia da linguagem, IN: Signos, São Paulo: Martins Fontes, 1996, p. 94, 95 
configura ultrapassando-se rumo a um sentido que ele não contém. Do mesmo modo como o corpo se move sem necessidade de representar seus movimentos, unificando-se graças à relação de suas partes em um projeto comum, a linguagem e a expressão estruturam-se pelo arranjo conjunto de seus termos, direção e sentido gerais que orientam seu movimento. A pintura e a linguagem prolongam, assim, o mesmo tipo de dinâmica expressiva presente no corpo: as palavras, organizadas segundo seu valor de uso, conforme um sentido operante e geral, são estruturalmente significativas de um todo mais amplo, expressões de uma unidade implícita que, ao mesmo tempo que as sustenta, é por elas sustentada. Tal como o corpo é imediatamente significativo de seu mundo e a percepção de seu objeto, os signos imediatamente exprimem seu significado ${ }^{191}$. Em todos os casos, o singular revela-se estruturalmente aberto, capaz de diferenciar-se, referir para além de si, transitar e vincular-se ao que lhe é outro ${ }^{192}$ : “(...) na experiência do outro, mais claramente (mas não diferentemente) do que na da palavra ou do mundo percebido, apreendo inevitavelmente meu corpo como uma espontaneidade que me ensina aquilo que não poderia saber a não ser por ela."193

191 “(...) a consciência que tenho de meu corpo é imediatamente significativa de uma certa paisagem ao meu redor (...) É da mesma maneira que a palavra, a que profiro ou a que ouço, é pregnante de uma significação que é legível na própria textura do gesto lingüístico (MERLEAU-PONTY. Maurice. Sobre a fenomenologia da linguagem, IN: Signos, São Paulo: Martins Fontes, 1996, p. 94, 95)

192 A relação entre linguagem e intersubjetividade é indicada pelo próprio autor (conforme principalmente seus cursos na Sorbonne: Merleau-Ponty à la Sorbonne, Cynara, 1998) e trabalhada por Bonan (BONAN, Ronald. L'institution intersubjective comme poétique générale v. 1, L'Harmattan, 2001, p. 246). A linguagem aparece - especialmente quando Merleau-Ponty trata do modo pelo qual a criança aprende e apreende a linguagem - como uma espécie de desdobramento de uma relação intersubjetiva originária. Em nossa leitura, supomos que isso reafirma o sentido geral da abertura como base de toda dinâmica expressiva.

193 MERLEAU-PONTY. Maurice. Sobre a fenomenologia da linguagem, IN: Signos, São Paulo: Martins Fontes, 1996, p. 100 
Contra a ideia de um ego transcendental ou constituinte, contra uma linguagem ou uma percepção que constituiria completamente seus significados, o que a referência ao corpo confirma é a abertura como traço originário da expressão ${ }^{194}$, o descentramento como condição de um sujeito inserido em um movimento que ele não engendra, no qual se abre e se transforma. Nelas, e especialmente na experiência de outrem - em que é impossível afirmar que a consciência constitui o outro como constituinte $^{195}$-, o corpo evidencia a "espontaneidade ensinante" que desde o início as análises de Merleau-Ponty procuravam circunscrever ${ }^{196}$. Seja no caso da linguagem, da percepção ou do corpo, a expressão se revela capaz de uma auto-configuração do sentido que antecede a separação entre o subjetivo e o objetivo, entre a existência concreta e a significação, afirmando-se como operador interno que realiza a transição de um termo ao outro. Em todos os casos, sua espontaneidade nos livra de nossas oposições ${ }^{197}$, funda um campo comum em que o signo e o sentido, o sujeito e o mundo, se comunicam originariamente. É por isso que, segundo Merleau-Ponty, se quisermos, como Sartre,

194 "Tudo se passa como se as funções de intencionalidade e de objeto intencional se encontrassem paradoxalmente trocadas. O espetáculo convida-me a tornar-me seu espectador adequado (...) Sou apanhado por um segundo eu mesmo fora de mim, percebo o outro... Ora, a palavra é um caso eminente dessas 'condutas' que invertem a minha relação comum com os objetos e dão a algum deles valor de sujeitos (MERLEAU-PONTY. Maurice. Sobre a fenomenologia da linguagem, IN: Signos, São Paulo: Martins Fontes, 1996, p. 100, 101)

${ }^{195}$ MERLEAU-PONTY. Maurice. Sobre a fenomenologia da linguagem, IN: Signos, São Paulo: Martins Fontes, 1991 p. 100

${ }^{196}$ Como já indicado no primeiro capítulo.

197 "Nesse sentido, há em toda expressão e mesmo na expressão pela linguagem uma espontaneidade que não suporta instruções, nem sequer as instruções que eu gostaria de dar a mim mesmo (...) Essa espontaneidade da linguagem que nos livra de nossas oposições não é uma instrução. A história que ela funda não é um ídolo exterior: é nós mesmos com nossas raízes, nosso crescimento próprio e os frutos de nosso trabalho (MERLEAU-PONTY, Maurice. A prosa do mundo, São Paulo: Cosac \& Naify, 2002, p.115, 116) 
afirmar um fundamento da linguagem, cabe reconhecê-lo não mais em uma apercepção, na relação imediata da consciência com seus objetos, mas justamente naquilo que, de cada conduta singular, a faz abrir-se para fora e para o outro, que a generaliza tornando-a momento de um todo e expressão particular de uma unidade comum:

"A linguagem tem realmente fundamento, como quer Sartre, mas não numa apercepção, ela está fundada no fenômeno do espelho ego-alter ego, ou do eco, isto é, na generalidade carnal: o que me aquece lhe aquece, pela ação mágica do semelhante sobre o semelhante (o sol quente me esquenta), pela fusão eu encarnado-mundo; esse fundamento não impede que a linguagem se volte dialeticamente sobre o que a precede e transforme essa coexistência com o mundo e com os corpos, puramente carnal, vital, em coexistência de linguagem."198

É a "carne" do mundo, em uma das primeiras referências explícitas à essa noção - que abordaremos de modo mais detido no IV capítulo, tratando de O Visível e o Invisível -, o fundamento da linguagem e, mais geralmente, da expressão. Todo ato expressivo, como vimos, se enraíza no mundo sensível, recorre à unidade pré-traçada no percebido, explicitando o Logos espontâneo que se confirma na abertura interna e referencial operante em cada ato e em cada percepção singular. Trata-se, pois, do mesmo tipo de síntese interna aos elementos de que o corpo dá testemunho ao relacionar-se com o mundo, quando domina a diversidade de suas partes e se articula como unidade expressiva:

198 MERLEAU-PONTY, Maurice. A prosa do mundo, São Paulo: Cosac \& Naify, 2002, p.42 
"A dominação do uno sobre o múltiplo da qual a história da pintura nos oferece o exemplo, assim como a que vimos no exercício do corpo que percebe, não consome a sucessão numa eternidade: ao contrário, ela exige a sucessão, tem necessidade dela, ao mesmo tempo que a funda em significação. E não se trata, entre os dois problemas, de uma simples analogia. É a operação expressiva do corpo, começada pela menor percepção, que se amplia em pintura e em arte."199

Reencontramos, enfim, o solo comum que sustenta essa síntese constantemente reencontrada pelo filósofo: a temporalidade, movimento que articula internamente o uno e o múltiplo, unidade espontânea que faz da diferença e da sucessão seus elementos constitutivos, configurando-os em significação. Sincronicidade entre diferença e unidade, encarregada de tornar uma constituinte do outra, a temporalidade se revela base comum às diversas descrições do filósofo, estrutura própria do movimento expressivo. Assim, por sob a aproximação que Merleau-Ponty propõe entre percepção, expressão e história, na síntese espontânea de que elas participam, podemos reconhecer a dinâmica temporal sustentando essa outra compreensão do processo significativo. É a ela que será reportada essa espontaneidade que escapa às oposições da ontologia clássica, que recusa a subjetividade como instância doadora de significação e ensina, como condição originária de toda singularidade, seu pertencimento a um processo geral que a configura em significação. Se a linguagem, como supomos, dispõe para o filósofo de uma dimensão ontológica é por revelar, do mesmo modo que a percepção e o corpo, esse movimento

199 MAURICE, Merleau-Ponty. A prosa do mundo, São Paulo: Cosac \& Naify, 2002, p. 111 
temporal ou esse Logos do mundo percebido, apontando para uma pré-constituição do sentido que demanda uma revisão das próprias noções de sujeito e objeto:

"Num sentido, a fenomenologia é tudo ou nada. Esta ordem da espontaneidade ensinante - o 'eu posso' do corpo, a 'transgressão intencional' que dá o outro, a 'palavra' que dá a idéia de uma significação pura ou absoluta - não pode ser depois recolocada sob a jurisdição de uma consciência acósmica ou pancósmica sob pena de voltar a não ter sentido, ele deve ensinar-me a conhecer o que nenhuma consciência constituinte pode saber: o fato de eu pertencer a um mundo 'pré-constituído'.,200

Recusando-se à categoria de constituinte do significado, a temporalidade como retomaremos no próximo capítulo ${ }^{201}$ - se aproxima da noção de instituição ${ }^{202}$, atuando como configuração espontânea da experiência, estabelecimento de dimensões privilegiadas em relação às quais os dados se organizam, se situam, respondendo por uma certa préconstituição estrutural que enforma o sujeito, o situa, sem contudo determiná-lo. Inauguração de uma ordem ou de um sentido que não provém do homem, mas se deposita nele $e^{203}$, a instituição é evento-matriz ${ }^{204}$, isto é, ela funda um estilo, abre um horizonte que tende a generalizar-se, a prosseguir seu movimento interno. Matriz simbólica ${ }^{205}$ que assegura a passagem do diverso e a coerência do todo, ela própria se revela apoiada na

${ }^{200}$ MERLEAU-PONTY. Maurice. Sobre a fenomenologia da linguagem, IN: Signos, São Paulo: Martins Fontes, 1991 p. 101

201 Acompanhando o movimento próprio às descrições de Merleau-Ponty, a questão da temporalidade será gradualmente explicitada ao longo de toda a Tese.

${ }^{202}$ Conforme especialmente seu curso sobre a instituição, ministrado no Collège de France em 1954 e 1955 (MERLEAU-PONTY, Maurice. L'institution, la passivité, Berlin, 2003)

${ }^{203}$ MERLEAU-PONTY, Maurice. L'institution, La passivité, Berlin, p. 44 e 46

204 Idem, p. 44

205 Idem, p. 45 
temporalidade: "O tempo é o modelo mesmo da instituição: passividade-atividade, ele continua, porque ele foi instituído, ele difunde-se, ele não pode deixar de ser, ele é total porque parcial, ele é um campo"206 . A temporalidade, enfim, compreendida como instituição em estado nascente ${ }^{207}$, funda uma unidade e uma síntese internas à experiência e à história, unifica o diverso pela abertura que instaura em cada singularidade. Passagem entre o subjetivo e o objetivo, ela configura um campo que recusa a exterioridade entre o sentido e a existência.

"A unidade da cultura prolonga mais além dos limites de uma vida individual o mesmo gênero de conexão que se estabelece entre todos os seus momentos quando uma vida é instituída, quando uma consciência, como se diz, é selada num corpo e aparece no mundo um novo ser a quem advirá não se sabe o quê, mas a quem doravante algo não poderia deixar de advir, que não poderia deixar de ter uma história breve ou curta. $\mathrm{O}$ pensamento analítico, cego para o mundo percebido, rompe a transição perceptiva de um lugar a outro, de uma perspectiva a outra, e busca do lado do espírito a garantia de uma unidade que já está aí quando percebemos, rompe também com a unidade da cultura e busca reconstituí-la de fora." ${ }^{208}$

É por essa razão, nos parece, que ao final de seu texto Sobre a fenomenologia da linguagem, após comentar a aptidão da fenomenologia da palavra para

\footnotetext{
${ }^{206}$ Idem, p. 36: "Le temps est le modele même de l'nstitution: passivité-activité, il continue, parce qu'il a eté institué, il fuse, il ne peut pas cesse d'être, il est total parce qu'il est partial, il est um champ" [tradução nossa]

${ }^{207}$ Idem, p. 36

${ }^{208}$ MERLEAU-PONTY, Maurice. A prosa do mundo, São Paulo: Cosac \& Naify, 2002, p.110
} 
revelar a ordem da "espontaneidade ensinante" ${ }^{209}$, Merleau-Ponty indique, remetendo a Kant e a Husserl, que a tarefa última da filosofia estaria em reconhecer a afinidade transcendental dos momentos, exatamente como aquilo que libera a síntese de um operador externo, recusa a finalidade em seu sentido dogmático e responde por uma unidade aberta que se recria constantemente pelo contato que mantém com a contingência ${ }^{210}$. Voltaremos a essas questões no decorrer da pesquisa.

209 MERLEAU-PONTY. Maurice. Sobre a fenomenologia da linguagem, IN: Signos, São Paulo: Martins Fontes, 1996, p. 103

210 Idem, p. 103 


\section{Gênese e Ontologia da visão}

1. Introdução

"A visão retoma o seu poder fundamental de manifestar, de mostrar mais do que a si mesma. E, já que nos dizem que um pouco de tinta basta para fazer ver florestas e tempestades, cumpre que ela tenha seu imaginário. A sua transcendência já não é delegada a um espírito leitor que decifre os impactos da luz-coisa sobre o cérebro, e que o faria igualmente bem se nunca houvesse habitado um corpo. Já não se trata de falar do espaço e da luz, e sim de fazer falarem o espaço e a luz que aí estão."211

Dando prosseguimento a nossa tentativa de circunscrever a filosofia de Merleau-Ponty em seu trabalho de dissolução dos paradigmas da ontologia clássica,

\footnotetext{
${ }^{211}$ MERLEAU-PONTY, Maurice. O Olho e o Espírito. In: Os Pensadores, São Paulo: Abril, 1975, p. 290
} 
passaremos agora do estudo feito no capítulo anterior sobre sua análise da linguagem ${ }^{212}$ a um comentário sobre seus últimos textos, especialmente O Olho e o Espírito e O Visível e o Invisível. Nosso foco, e também justificativa para a passagem analítica do tema da linguagem ao da ontologia de seu último período, será explicitar o modo pelo qual estas obras conservam a afirmação diretriz do sentido como estrutura dotada de ecceidade, espontaneamente formada por um processo interno e auto-regulado distante da cisão clássica entre sujeito e objeto, tese balizar na filosofia de Merleau-Ponty, presente desde a Estrutura do Comportamento, central na Fenomenologia da Percepção e retomada por sua análise da linguagem ${ }^{213}$. Tentaremos mostrar que, assim como em seus estudos anteriores $^{214}$, também aqui essa tese se assenta em uma compreensão ontológica que recusa a ruptura completa entre o Ser e o Nada, encontrando-os como momentos reciprocamente dependentes articulados em um movimento comum, dimensões reversíveis no interior de uma unidade diacrítica.

Essa constatação nos permitirá manter a proposta de que um dos eixos da filosofia de Merleau-Ponty está justamente no reconhecimento dessa gênese interna e autoregulada da significação, afirmando a existência de um Ser que se furta aos paradigmas da

212 Conforme o capítulo anterior.

${ }^{213}$ Conforme os dois primeiros capítulos de nossa pesquisa. Quanto à presença desse tema na Fenomenologia da Percepção, procuramos indicá-la, de modo mais detido, em nossa pesquisa de Mestrado (MOURA, Alex de Campos. Liberdade e situação em Merleau-Ponty: uma perspectiva ontológica, São Paulo: Humanitas, 2010), tentando indicar como já ali a compreensão de Merleau-Ponty sobre o sentido adquire uma dimensão ontológica, recusando a dualidade da ontologia clássica.

214 Essa é uma de nossas teses principais: a afirmação de que há, desde o início da obra de Merleau-Ponty, uma base ontológica por sob suas descrições, orientada pelo projeto de escapar aos dualismos estabelecidos pelo pensamento clássico e pela ontologia cartesiana. Conforme indicado nos capítulos anteriores e em nossa pesquisa de Mestrado. 
ontologia clássica, sobretudo à dicotomia entre uma subjetividade considerada como puro constituinte e um objeto tomado como puro constituído. A revisão ontológica empreendida pelo filósofo, e tema de nossa pesquisa, aparece assim vinculada à reconfiguração da noção de sentido, estrutura hibrída que recusa tanto a categoria de objeto quando a de idealidade ${ }^{215}$. Nessa direção, procuraremos confirmar nossa hipótese de que suas diferentes análises - sobre o tempo, a percepção, a linguagem e a visão ${ }^{216}$ - se aproximam pela tentativa recorrente de se afastarem do modelo tradicional de constituição, apontando para um tipo de Ser que desconhece a alternativa entre o ativo e o passivo, o sujeito e o objeto. Elas se aproximam, assim, como procuraremos indicar ao longo do capítulo, pela tendência a gravitar em torno daquilo que o filósofo denominará instituição. ${ }^{217}$

Prosseguindo a análise dos capítulos anteriores, será ainda sob essa perspectiva de reconfiguração ontológica que tentaremos indicar uma hipótese para o privilégio dado pelo filósofo - não apenas neste ensaio, mas ao longo de sua obra ${ }^{218}$ - à

${ }^{215}$ Conforme nossa leitura, a articulação entre a compreensão do sentido e a proposição de uma nova ontologia é um dos eixos da filosofia de Merleau-Ponty, presente desde o início de sua obra, fundamental em suas principais descrições, como aquelas referentes ao tempo, à percepção, ao mundo e à linguagem. Conforme os capítulo anteriores e nossa pesquisa de Mestrado.

${ }^{216}$ Trabalhadas nos capítulos anteriores e em nossa pesquisa de Mestrado (MOURA, Alex de Campos. Liberdade e situação em Merleau-Ponty: uma perspectiva ontológica, São Paulo: Humanitas, 2010).

217 Explicitaremos esse ponto mais adiante.

${ }^{218}$ Tema constante ao longo dos trabalhos de Merleau-Ponty, a pintura ocupa desde o início um importante papel em sua reflexão filosófica. Ela aparece, por exemplo, já na Fenomenologia da Percepção, apontando para um sentido que se mantém vinculado ao percebido e para uma síntese não posicional que permanece atada à estruturação interna dos elementos com os quais opera, aquém da cisão entre a atividade do sujeito e a passividade do objeto. Já ali, portanto, segundo nossa leitura, inserida no projeto mais amplo do autor de uma reformulação ontológica (Conforme nossa pesquisa de Mestrado). Em função semelhante, ela aparece no ensaio $A$ dúvida de Cézanne, explicitando como a obra de um artista não pode se esgotar em um campo nem inteiramente subjetivo e nem inteiramente objetivo, estruturando-se por uma espécie de reflexividade simbólica que preserva tanto as condições contingentes que a motivam quanto o gesto livre que a efetiva. A obra se revela como uma espécie de movimento reativo que incorpora e transforma o dado (Conforme: MERLEAU-PONTY, Maurice. A dúvida de Cézanne. In: Os Pensadores, São Paulo: Abril, 1975). O tema 
pintura, procurando mostrar que um dos motivos de sua centralidade está precisamente no fato dela ser um espaço privilegiado de explicitação deste novo sentido do Ser que recusa a ontologia clássica e suas concepções dualistas.

Para o tratamento dessas questões, nos concentraremos, nessa primeira parte do capítulo, principalmente em O Olho e o Espírito, reservando a segunda para o tratamento de O Visível e Invisível.

da pintura aparece ainda em praticamente toda discussão de Merleau-Ponty sobre a linguagem, conforme indicado no capítulo anterior.

Sobre o tema da pintura, ver, por exemplo, os livros de Carbonne (CARBONE, Mauro. Al Confini dell'esprimible. Merleau-Ponty a partire da Cézanne e da Proust, Milano: Edizioni Angelo Guerini, 1990; e Il sensible e l'excedente. Mondo estetico, arte, pensiero, Milano: Edizioni Angelo Guerini, 1996), que fazem uma cuidadosa análise sobre a noção de expressão em Merleau-Ponty, explicitando seus diversos desdobramentos; e o livro de Moutinho (MOUTINHO, Luiz Damon Santos. Razão e experiência em Merleau-Ponty, São Paulo: UNESP, 2006), que trata do tema principalmente enfocando seus deslocamentos, do período inicial, por volta de 1945, até sua apresentação já dentro de uma discussão mais ampla sobre a linguagem, por volta de 1952 . 


\section{A fusão do vidente e do visível}

"Isso a que se chama inspiração deveria ser tomado ao pé da letra: há deveras inspiração e expiração do Ser, respiração no Ser, ação e paixão tão pouco discerníveis, que já não se sabe quem vê e quem é visto, quem pinta e quem é pintado. Dizse que um homem nasceu no momento em que aquilo que, no fundo do corpo materno, não passava de um visível virtual torna-se ao mesmo tempo visível para nós e para si. A visão do pintor é um nascimento continuado."219

A existência de uma dimensão ontológica na reflexão sobre a pintura e, de modo mais geral, sobre a visão, é uma questão para a qual o próprio Merleau-Ponty chama a atenção. Ao comentar a Dióptrica, texto de Descartes ${ }^{220}$ sobre o tema, ele procura indicar

219 MERLEAU-PONTY, Maurice. O Olho e o Espírito. In: Os Pensadores, São Paulo: Abril, 1975, p. 282

${ }^{220}$ O diálogo de com Descartes é um traço constante na filosofia de Merleau-Ponty, central na construção de suas descrições. O diálogo com o pensamento cartesiano, na verdade, parece ser característico da fenomenologia de um modo geral . A esse respeito, ver: MOURA, Carlos Alberto Ribeiro de. Racionalidade e crise. São Paulo: Discurso Editorial / Edufpr, 2001, especialmente seu ensaio Cartesianismo e fenomenologia: Exame de paternidade. 
que toda teoria da pintura implica uma compreensão do Ser, reveste-se de uma significação metafísica $^{221}$ e indica uma certa concepção da relação entre a singularidade e a totalidade do $\operatorname{Ser}^{222}$.

Merleau-Ponty mostra que há, por sob a análise cartesiana, como seu fundamento, o pressuposto do Ser como absoluta positividade, entidade homogênea e uniforme que se ofereceria completamente à visão. É isso que permite a Descartes afirmar, por exemplo, a profundidade como uma simples variação da largura e do comprimento ${ }^{223}$, e o espaço como unidimensional ${ }^{224}$, explícito de ponta à ponta. Para que essas concepções sejam efetivas, indica Merleau-Ponty, é preciso que o Ser a que se referem seja aquilo que se oferece ao sujeito sem restrições, desprovido de atividade própria e de espessura. Ele deve ser, como mostra o próprio Descartes em outros momentos ${ }^{225}$, objeto puro, construção positiva e intelectual. O Ser deve ser plano, espacializado segundo duas dimensões completamente determináveis, transparente e imóvel: “É esse espaço sem esconderijo que, em cada um de seus pontos é, nem mais nem menos, o que ele é, é essa identidade do Ser que sustenta a análise dos talhos-doces (...) Havia, primeiro, que idealizar o espaço, conceber esse ser perfeito no seu gênero, claro, manejável e homogêneo, que o

221 "O que nos interessa nessas célebres análises é que elas tornam perceptível que toda teoria da pintura é uma metafísica." (MERLEAU-PONTY, Maurice. O Olho e o Espírito. In: Os Pensadores, São Paulo: Abril, 1975, p. 285)

${ }^{222}$ Como indicaremos mais adiante, a afirmação de uma relação interna entre a parte e o todo, o singular e o geral, é um dos pontos principais no recurso de Merleau-Ponty à visão, e elemento central na formulação de sua ontologia.

${ }^{223}$ MERLEAU-PONTY, Maurice. O Olho e o Espírito. In: Os Pensadores, São Paulo: Abril, 1975, p. 285, 286

${ }^{224}$ Idem, p. 286

${ }^{225}$ Conforme, por exemplo, as Meditações (DESCARTES, R. Meditações. In: Os Pensadores, São Paulo: Abril, 1975) 
pensamento sobrevoa sem ponto de vista (...)"226

Desse modo, segundo Merleau-Ponty, a análise cartesiana da pintura se baseia nessa suposição de um Ser inteiramente uniforme, objeto posto e dominado pela consciência. Ele sugere que o fato mesmo de Descartes passar apenas de passagem pelo tema é já indicativo de sua implicação ontológica. Um exame mais detalhado da pintura, que reconhecesse a impossibilidade do espaço como unidimensional e do visível como construção, poderia tê-lo conduzido a uma outra filosofia, apontando para um entendimento diverso sobre o Ser e seu sentido. Como tentaremos mostrar ao longo desse capítulo, é justamente em direção a essa outra compreensão implícita pela pintura que se dirige Merleau-Ponty, recorrendo à ela como recusa do modelo ontológico clássico, buscando em sua atividade a explicitação de um tipo de Ser capaz de configurar-se espontaneamente, organizar-se como significação sem o recurso a uma instância externa. A pintura, como veremos, deixará de ser técnica ou artifício, recusará a idéia de representação, para recuperar o movimento de gênese interno ao visível, um modo de Ser que se faz articulando internamente o concreto e a significação. Será de um poder ontológico mais amplo e já operante que ela extrairá sua atividade significativa, explicitando e prolongando um movimento que não provém de si própria e que se afasta dos parâmetros clássicos apontados por Descartes:

"Se houvesse examinado esta outra e mais profunda abertura às coisas que as qualidades segundas nos proporcionam, notadamente a cor, como não há relação

${ }^{226}$ MERLEAU-PONTY, Maurice. O Olho e o Espírito. In: Os Pensadores, São Paulo: Abril, 1975, p. 287 
regulada ou projetiva entre elas e as propriedades verdadeiras das coisas, e como, no entanto, a mensagem delas é compreendida por nós, Descartes teria se achado diante do problema de uma universalidade e de uma abertura-às-coisas sem conceito, teria se visto obrigado a indagar como o murmúrio indeciso das cores pode apresentar-nos coisas, florestas, tempestades, enfim o mundo, e talvez integrar a perspectiva em um poder ontológico mais amplo."227

Será esse poder ontológico mais amplo do qual a pintura participa o ponto central para Merleau-Ponty. Trata-se, como veremos, de um movimento espontâneo de configuração do Ser e do sentido, presente na visão e estruturado por uma abertura intrínseca que conduz da parte ao todo ${ }^{228}$, do signo ao significado, sem o auxílio de um agente externo. Processo de gênese que se faz por transição interna dos termos e não mais por sua oposição ou assimilação, pondo em suspenso a ruptura proposta pela Tradição. Reencontrando o que indicamos em nossas análises anteriores, a referência do filósofo à pintura e, com ela à visão, desse modo se precisa: como mostraremos no decorrer do capítulo, elas devem explicitar essa estrutura espontaneamente significativa do Ser, ensinando uma noção nova de criação e de sentido. A ontologia de Merleau-Ponty, como estamos procurando sustentar ao longo da Tese, tem como marca o esforço em preservar a ecceidade do mundo, em dilatar o processo expressivo para todo o sensível, propondo um tipo de Logos ou de articulação operante que se faz como passagem interna entre o

\footnotetext{
${ }^{227}$ MERLEAU-PONTY, Maurice. O Olho e o Espírito. In: Os Pensadores, São Paulo: Abril, 1975, p. 286

${ }^{228}$ Como indicado acima, trataremos dessa relação entre a parte e o todo, e de sua explicitação pela visão, mais adiante.
} 
subjetivo e o objetivo, revelando-os sincrônicos e reversíveis.

É justamente pela indicação desse projeto ontológico mais amplo que se inicia o O Olho e o Espírito, assumindo explicitamente o propósito de recusar a ontologia latente na ciência de sua época ${ }^{229}$, especialmente em sua suposição de uma separação total entre sujeito e objeto. Segundo Merleau-Ponty, a ciência manipula os objetos, constrói teorias e as sobrepõe à realidade. Sem vínculo com seu tema, tornado agora apenas um produto intelectual, ela se torna pensamento abstrato, razão formal e instrumentalizada que domina seu objeto destituindo-o de interioridade, "pensamento de sobrevôo". Operando em descompasso com o real, a ciência nega qualquer dependência com relação àquilo de que trata, é construção e não explicitação: exercício de uma razão abstrata sem lugar e sem tempo, ela opera com o pressuposto de que o objeto é aquilo que é absolutamente, ser idêntico determinado pela subjetividade, e de que o sujeito é instância constituinte, ser inteiramente translucido para si, fonte de toda significação e de todo sentido ${ }^{230}$. Opera, pois, com a ontologia que separa sujeito e objeto, fazendo do segundo uma expressão derivada

229 MERLEAU-PONTY, Maurice. O Olho e o Espírito, In: Os Pensadores, São Paulo: Abril, 1975, p. 275

230 Apenas como observação, julgamos importante indicar que nessa crítica pode-se reconhecer um dos encaminhamentos da filosofia de Merleau-Ponty que permite um desdobramento ético, e mesmo político, em suas proposições. Não nos parece equivocado reconhecer a proximidade entre aquilo que o filósofo chama de "pensamento de sobrevôo" e o que se compreende por ideologia. Se o discurso ideológico é aquele que se sobrepõe à realidade, mascarando as relações efetivas do real por meio de uma construção que permanece arbitrária e que se implanta por meio da violência, a crítica constante de Merleau-Ponty à separação entre o pensamento e seu objeto, entre a linguagem e o real, seu esforço em mostrar a matriz mundana de todo pensamento e de todo gesto, não deixam de configurar alternativas e respostas à ideologia e a sua pretensa autonomia em relação ao objeto. Conforme a noção de ideologia e de razão formal proposta por Adorno, por exemplo, em A Dialética do Esclarecimento. 
da atividade formativa do primeiro. Como indicamos acima e desenvolveremos no correr do texto, é justamente contra essa ontologia dualista que se coloca o estudo de Merleau-Ponty sobre a visão e, em particular, sobre a pintura.

Seu primeiro movimento nessa recusa é mostrar a inserção do pensamento pretensamente ilimitado suposto pela ciência em uma dimensão corporal e situacional, obrigando ao reconhecimento de um "há prévio"231 que prescinde do poder constituinte do sujeito e do qual a ciência tenta a todo custo desvincular-se. Para essa reinserção, é fundamental a referência de Merleau-Ponty ao corpo - assim como já ocorria em sua análise sobre a linguagem, abordada nos capítulos anteriores. Tema central em sua filosofia, o corpo é compreendido por ele desde o início como uma estrutura híbrida, impossível de ser reduzida à categoria de objeto ou de sujeito. Como procuramos mostrar em nossa pesquisa de Mestrado ${ }^{232}$, desde a Estrutura do comportamento, ele se oferece como "terceiro gênero de ser", tese central retomada pela Fenomenologia da Percepção, onde o corpo se revela significação encarnada e expressão viva, passagem espontânea entre o para-si e o em-si, responsável pela transição entre a "existência em primeira pessoa" e a "escolástica dessa existência", generalização da singularidade do ato na constância do hábito. Como tentamos mostrar ali, o corpo responde por uma simultaneidade entre espírito e matéria calcada na articulação originária entre o Ser e o Nada, configurando-se como unidade aberta formada por uma negatividade estrutural ${ }^{233}-$ como $^{2}$

${ }^{231}$ Como veremos no segundo capítulo, esse "há prévio" é também central em $O$ Visível e Invisível, explicitando a pré-constituição do Ser, estruturação espontânea e "selvagem" que recusa a ontologia clássica.

232 MOURA, Alex de Campos. Liberdade e situação em Merleau-Ponty: uma perspectiva ontológica, São Paulo: Humanitas, 2010

${ }^{233}$ Evidentemente, essa compreensão exige uma série de descrições que a embasem. Procuramos fazê-lo em 
veremos, trata-se da mesma configuração que as descrições abordadas agora revelam, contribuindo para nossa hipótese sobre a existência de um projeto ontológico que se mantém ao longo da obra do filósofo.

Retomando, desse modo, suas análises anteriores, o corpo figura também aqui como estrutura situada aquém da cisão entre o subjetivo e o objetivo, testemunho de um modo de ser que se faz pela imbricação de um no outro. No caso de O Olho e o Espírito, ele é central sobretudo por portar a estrutura simultaneamente unitária e reversível própria à visão, encarnando a fusão entre vidente e visível que será central na ontologia de Merleau-Ponty: "O enigma reside nisso: meu corpo é ao mesmo tempo vidente e visível"234. Enquanto visibilidade situada, o corpo se tornará paradigma da constituição recíproca existente entre o ativo e o passivo, apontando a insuficiência da dicotomia clássica entre um puro constituinte e um puro constituído. No ensaio, ele é definido por Merleau-Ponty como "entrelaçado de visão e de movimento" ${ }^{235}$, o que por si só já implica um distanciamento com relação ao modelo ontológico clássico: “[Essa superposição de visão e movimento] impede concebermos a visão como uma operação de pensamento que ergueria diante do espírito um quadro ou uma representação do mundo, um mundo da imanência e da idealidade. Imerso no visível por seu corpo, embora ele próprio visível, o vidente não se apropria daquilo que vê: só se aproxima dele pelo olhar, abre-se para o mundo. E, por seu lado, esse

\footnotetext{
nossa pesquisa de Mestrado.

${ }^{234}$ MERLEAU-PONTY, Maurice. O Olho e o Espírito. In: Os Pensadores, São Paulo: Abril, 1975, p. 278

235 Idem, p. 278.

Bonan, ao analisar o sentido da ação em Merleau-Ponty, aponta para a importância da motricidade como base do movimento significativo, intencionalidade originária (BONAN, Ronald. Merleau-Ponty de la perception à l'action, Université de Provence, 2005).
} 
mundo, do qual ele faz parte, não é em si ou matéria." ${ }^{236}$

Recusando o modelo clássico e seu paradigma da constituição, a inserção da visão em uma estrutura corporal implica a relativização das noções tanto de sujeito quanto de objeto. Atada ao mundo, ela deixa de ser expressão da atividade de um espírito capaz de engendrar e dominar completamente seu objeto, deixa de ser posse e identidade para revelar-se como distância e abertura, descentramento e diferenciação que se fazem, como veremos $^{237}$, estabelecendo uma relação estrutural entre a parte e o todo que assegura a ecceidade do objeto e a atividade intrínseca ao mundo, afastando-os da categoria de matéria inerte ${ }^{238}$. A visão não constrói o termo ao qual se dirige e nem se apropria dele, ela não simboliza mais, como na Tradição, a luz de uma razão absoluta capaz de penetrar a totalidade do que lhe aparece. Ao contrário, ela se torna agora emblema da relação orgânica existente entre o espírito e o mundo, entre o agente e seu objeto, revelando-os como momentos diversos de uma estrutura única: "Estes deslocamentos, essas antinomias são maneiras diversas de dizer que a visão é tomada ou se faz no meio das coisas, de lá onde um visível se põe a ver, torna-se visível por si e pela visão de todas as coisas, de lá onde, qual a água-mãe no cristal, a indivisão do senciente e do sentido persiste."239

Inserido no mundo por seu corpo, o vidente não apenas vê, mas se torna

\footnotetext{
236 Idem, p. 278

${ }^{237} \mathrm{O}$ tema da visão, conforme o movimento próprio às descrições do filósofo, será indicado diversas vezes, retomado, e gradualmente explicitado. Por isso, nos concentraremos nele especialmente ao final desta primeira parte do capítulo.

238 Trataremos da compreensão do mundo um pouco mais adiante, explicitando como também ele recusa a dualidade entre sujeito e objeto, atividade e passividade, articulando-as como dimensões de uma estrutura única.

239 MERLEAU-PONTY, Maurice. O Olho e o Espírito. In: Os Pensadores, São Paulo: Abril, 1975, p. 279
} 
também visível, visibilidade exposta a outrem e, no limite, a todos, evidenciando que o exercício da visão implica necessariamente uma passividade no interior de seu ato: originariamente situada, ela é ativa apenas enquanto inscrita nessa estrutura geral que a faz também passiva, tornando-a visível ${ }^{240}$. Enquanto percebe e vê, o corpo é sujeito; enquanto é percebido e visto, ele é objeto, possibilidade de se oferecer ao olhar de um outro: ou seja, visibilidade situada, o corpo é a um só tempo sujeito e objeto, ação e receptividade. Questão central para a ontologia de Merleau-Ponty, ele o é simultaneamente, as duas condições são nele sincrônicas. Como ficará claro na descrição do Cogito, de que trataremos a seguir, não há dualidade no corpo, mas sim uma espécie de reversibilidade originária entre sua dimensão ativa e sua dimensão passiva. Situado e vulnerável, o sujeito deixa de ser posição para descobrir-se quase objetivo; vidente-visível, ele permanece sensível para si mas também para outrem, dotado de um "exterior" e de uma abertura que o impedem de repousar em si, de isolar-se na forma da identidade. Tanto o sujeito quanto o objeto $^{241}$ encontram-se assim reconfigurados.

${ }^{240}$ Como indicado acima, o corpo, por si, já assegura uma espécie de reversibilidade entre o singular e o geral, entre a existência em "primeira pessoa" e a generalidade do hábito e da cotidianeidade. Estrutura ontológica nova, o corpo é desde o início da obra de Merleau-Ponty arquétipo de uma fusão não identitária entre o parasi e o em-si. Conforme nossa pesquisa de Mestrado (MOURA, Alex de Campos. Liberdade e situação em Merleau-Ponty: uma perspectiva ontológica, São Paulo: Humanitas, 2010).

Como afirma Hubeny, por uma linha analítica diversa, a encarnação para Merleau-Ponty é menos um enclausuramento da consciência no corpo, do que sua abertura a um mundo comum e intersubjetivo, no qual o sujeito não pode se definir como puro pensamento, mas como situação, e sua liberdade não pode afirmarse como um poder absoluto de escolha, vindo daí uma espécie de sustentação recíproca ou de unidade entre o engajamento e a liberdade: 'L'action n'est pas libre au sens òu le serait lu jugement ou la décision d'une conscience détachée du monde. L'exercise de la liberté est une certaine manière d'entretenir - c'est-à-dire à la fois de conserver et de modifier, de faire crôitre - les liens que nous avons noués avec le monde et avec les autres depuis notre naissance.” (HUBENY, Alexandre. Jouer um rôle, IN: BONAN, Ronald (éd). Merleau-Ponty - de la perception à l'action, Publications de L'Université de Provence, 2005, p. 68)

241 Explicitaremos um pouco mais adiante o modo pelo qual o objeto é também reconfigurado. 
O próprio Cogito, pelo qual o pensamento clássico definia a subjetividade, descobre-se agora inserido organicamente no mundo. Na medida em que o homem é visão que vê e que se dá a ver, ele próprio pode apreender sua aparição, pode ver-se vendo, perceber-se percebendo, mantendo sua capacidade auto-reflexiva. Essa contudo não é mais identidade ou imanência, mas uma espécie de estrutura "reflexo-refletidor"242, em que os termos, embora indissociáveis, não coincidem, estabelecendo ao contrário um movimento infinitamente intercambiável. Entre seu ato de ver e de ser visto, há uma espécie de distância ou abertura interna ${ }^{243}$ que o impede de coincidir consigo, pois enquanto sensível, ele se generaliza, abre-se a horizontes e a visões que o ultrapassam, e enquanto senciente, seu ato o afasta de si, abre-se ao que não é ele. Tanto um quanto outro não são inteiramente singulares, mas participantes de um movimento espontâneo de generalização que os afasta de $\mathrm{si}^{244}$. O recurso à visão permite a Merleau-Ponty encontrar os moldes de uma atividade que não apreende seu objeto e não se identifica a seu ato, que se distende

${ }^{242}$ O termo é de Sartre, usado para definir justamente sua noção de Cogito existencial. Fazemos referência a ele aqui precisamente para indicar sua distância em relação às formulações de Merleau-Ponty. Embora ambos busquem explicitar uma dimensão existencial e não identitária no Cogito, buscando recusar a imanência da consciência sem recair em um inconsciente (Conforme O Ser e o Nada e a Fenomenologia da Percepção), para Sartre, a "dualidade" ou a estrutura de reflexos do Cogito permanece própria e exclusiva do Para-si, intrínseca à consciência enquanto negatividade, distância de si que é o próprio modo de ser do Para-si, não implicando portanto nenhuma intromissão do mundo (Conforme O Ser e o Nada). Para Merleau-Ponty, ao contrário, a estrutura de reflexos caraterística do Cogito se assenta em sua corporeidade e, por meio dela, em sua abertura originária ao mundo e ao sensível. Ela não é referência circular de uma consciência fechada sobre si, mas abertura e generalização estruturais da consciência (Conforme a Fenomenologia da Percepção e nossa pesquisa de Mestrado)

${ }^{243}$ Como explicitaremos mais adiante, a estrutura reflexiva do corpo, do sensível e do Cogito, se assenta em um tipo Ser cuja unidade se forma por diferenciação interna, que não repousa em si, configurando-se justamente por dissonância e negatividade estruturais.

244 Isso ficará mais claro quando analisarmos a estrutura da visão, simultaneamente unitária e não identitária. 
ao exercer-se, diferencia-se e generaliza-se, mantendo-se contudo ligada a si e ao objeto por meio de uma compossibilidade geral, de uma organicidade do todo assegurada pela coesão das partes. ${ }^{245}$

Assim como na Tradição o Cogito significava o encontro entre o ato de pensar e o objeto pensado, aqui também há uma articulação entre sujeito e objeto, só que não mais pela redução de um ao outro, e sim pelo reconhecimento de uma estrutura unitária e não idêntica, no interior da qual eles se revertem um no outro constantemente sem identificação ou assimilação possível: "É um si, não por transparência, como o pensamento, que só pensa o que quer que seja assimilando-o, constituindo-o, transformando-o em pensamento - mas um si por confusão, por narcisismo, por inerência daquele que vê naquilo que ele vê, daquele que toca naquilo que ele toca, do senciente no sentido - um si, portanto, que é tomado entre as coisas, que tem uma face e um dorso, um passado e um futuro..."246

Distante das noções de identidade e de constituição, o Cogito é agora expressão de uma unidade internamente diferenciada, estrutura dinâmica que, ao voltar-se sobre si, não anula a distância mínima que distingue o agente e o objeto, o ver e o ser visto, reunindo-se justamente pela reversibilidade existente entre eles, movimento interno que nem os identifica e nem os permite repousar em $\mathrm{si}^{247}$ - estrutura de reflexos que confirma uma configuração ontológica diversa da suposta pelo pensamento clássico. A unidade ${ }^{245}$ Como explicitaremos mais adiante.

${ }^{246}$ MERLEAU-PONTY, Maurice. O Olho e o Espírito, In: Os Pensadores, São Paulo: Abril, 1975, p. 279

${ }^{247}$ É importante notar, conforme nossa hipótese de trabalho, que esse tipo de unidade - processual e diacrítica revelada no Cogito é o mesmo presente no corpo, no sensível, na visão... estabelecendo, como veremos, uma espécie de estrutura ontológica comum nos diferentes níveis de experiência. 
diacrítica do corpo revela-se unidade diacrítica do si.

Assim como o corpo não é mais um conjunto de partes exteriormente ligadas, ser objetivo e determinado ao qual se ligaria de fora uma consciência, também o si não é mais um puro ato sem vínculos com o mundo, ser subjetivo capaz de apreender-se completamente. Postos como unidade, articulados pela reversibilidade entre o visível e o vidente, eles implicam agora um si situado e um corpo espiritualizado, isto é, implicam a impossibilidade de se conceber um termo sem o outro, de afirmar cada um como uma realidade autônoma em relação ao outro. Estrutura mista que reflete e reflexiona no interior do mundo sensível, o corpo torna-se enfim arquétipo da sincronicidade que põe em suspenso os marcos ontológicos tradicionais, recusa a alternativa entre identidade e alteridade e embaralha os lugares e limites entre o sujeito e o objeto:

“(...) [o corpo humano surge quando] entre vidente e visível, entre tateante e tocado, entre um olho e outro, entre a mão e a mão, faz-se uma espécie de recruzamento, quando se acende a centelha do senciente-sensível, quando esse fogo que não mais cessará de arder pega, até que tal acidente do corpo desfaça aquilo que nenhum acidente teria bastado para fazer."248

Se a estrutura ontológica reversível do corpo põe em suspenso a possibilidade de um Cogito puro, o mesmo ela faz em relação ao objeto e, de modo mais geral, ao mundo, e veremos agora que sua unidade reflexiva desdobra-se também no

${ }^{248}$ MERLEAU-PONTY, Maurice. O Olho e o Espírito. In: Os Pensadores, São Paulo: Abril, 1975, p. 279 
sensível. Se a estrutura complexa do corpo, enquanto "estofo comum" ${ }^{249}$ entre sujeito e objeto, nos impede de distinguí-lo absolutamente de uma coisa, é preciso que sua estrutura reversível opere também nelas: a manifesta visibilidade do objeto deve se reforçar por uma solidez interna, atividade própria que a impeça de ser apenas objetiva e passiva ${ }^{250}$. Tal como ocorria na Fenomenologia da Percepção ${ }^{251}$, em que a dinâmica expressiva presente no corpo revelava-se operante em todo o sensível, também aqui a estrutura corporal se dilata e se afirma como configuradora do mundo sensível, impedindo-o de ser reduzido à categoria de objeto. Se o corpo, enquanto coisa n(d)o mundo, ser sensível e visível, é capaz de agir e reflexionar-se, é preciso que haja uma reflexividade e uma atividade próprias ao sensível, é preciso que ele se descubra portador de uma dinâmica interna que lhe assegure sua ecceidade. Dilatando a estrutura híbrida do corpo, também ele deve operar como uma espécie de unidade internamente diferenciada, totalidade feita da simultaneidade entre o ativo e o passivo. No caso do sensível, como nossas análises seguintes procurarão mostrar - especialmente ao tratarmos do mundo sensível - isso implica a existência de um processo de gênese interno a ele, configuração espontânea do sentido assegurada por sua estrutura dialógica e ativa, não mais dependente de uma ação externa. Articulando sentido e existência, unidade e multiplicidade, ele próprio se revelará como uma unidade diacrítica, capaz de exprimir-se e configurar-se por sua própria reflexividade interna. Longe de objeto

249 Idem, p. 279

250 Idem, p. 279

251 Conforme indicado anteriormente, o percurso analítico que vai do corpo ao sensível - que desdobra a significação encarnada e a expressividade concreta encontradas no corpo para todo o mundo sensível - já está presente na Fenomenologia da Percepção, conforme nossa pesquisa de Mestrado (MOURA, Alex de Campos. Liberdade e situação em Merleau-Ponty: uma perspectiva ontológica, São Paulo: Humanitas, 2010). 
ou construção, também o sensível se revelará como manifestação da unidade ontológica defendida por Merleau-Ponty.

É justamente essa unidade, espontânea e auto-reflexiva, que, pela mediação do corpo, passa a caracterizar tanto o sujeito quanto o objeto, que o espelho testemunha. Técnica que amplia o trabalho da visão, ele desdobra a estrutura ontológica do sensível e do corpo, potencializando a intercambialidade existente entre o subjetivo e o objetivo, entre o agente e o passivo. O espelho confirma, por sua operação, a estrutura ontológica única no interior da qual os termos se diferenciam e se trocam constantemente sem separar-se uns dos outros: “(...) [O espelho] figura e amplia a estrutura metafísica de nossa carne. O espelho aparece porque eu sou vidente-visível, porque há uma reflexividade do sensível; ele a traduz e reduplica (...) ele é o instrumento de uma universal magia que transforma coisas em espetáculos, os espetáculos em coisas, eu no outro e o outro em mim. Os pintores muitas vezes refletiram sobre os espelhos porque, por sob esse 'truque mecânico' como por sob o truque da perspectiva, reconheciam a metamorfose do vidente e do visível, que é a definição da nossa carne e a da vocação deles" ${ }^{\text {252 }}$. Ele confirma, enfim, a reciprocidade entre metamorfose interna e unidade geral do processo, isto é, confirma um modo de ser cuja unidade se forma pela reversibilidade estrutural de seus elementos. Tanto o sujeito quanto o objeto, nossa "carne" e a do sensível ${ }^{253}$, passam a se configurar portanto pela auto-diferenciação e pela reversibilidade constitutiva dessa totalidade mais ampla,

${ }^{252}$ MERLEAU-PONTY, Maurice. O Olho e o Espírito. In: Os Pensadores, São Paulo: Abril, 1975, p. 283

253 A noção de carne, central - como veremos no próximo capítulo - em O Visível e Invisível, já aparece aqui, expressão da reversibilidade fundamental na ontologia de Merleau-Ponty. 
atados a um outro processo de unificação e de coesão que se faz espontaneamente pela relação diacrítica de seus termos. Movimento, como veremos, interno ao Ser, de transformação, tornar-se visível e instituir-se, graças à passagem espontânea que une o visível e o vidente, desconhecendo a alternativa entre sujeito e objeto puros.

É precisamente em meio a delimitação desse domínio ontológico implicado pela análise do corpo visível-vidente e do sensível como unidade reflexiva que a questão da pintura é introduzida em O Olho e o Espírito. Isso porque, conforme nossa hipótese indicada acima, a pintura será para Merleau-Ponty um espaço privilegiado na explicitação desse Ser formado pela reversibilidade entre sujeito e objeto, desdobrando a estrutura ontológica do corpo e do mundo: "Eles [os problemas da pintura] ilustram o enigma do corpo, e ela justifica-os (...)"254. Prosseguindo a dinâmica corporal, ela se aloja na reflexividade espontânea do mundo e do Ser, recusa a idéia de constituição como posição e o dualismo da ontologia clássica, negando a formação do sentido como processo tributário das decisões de uma consciência desengajada, operando como prosseguimento da gênese por auto-diferenciação que descobre no mundo, que ecoa no corpo e testemunha a dimensão instituinte do Ser:

"Qualidade, luz, cor, profundidade, que estão aí diante de nós, aí só estão porque despertam um eco em nosso corpo, porque este lhes faz acolhida. Este equivalente interno, esta fórmula carnal de sua presença que as coisas suscitam em mim, por que não

${ }^{254}$ MERLEAU-PONTY, Maurice. O Olho e o Espírito. In: Os Pensadores, São Paulo: Abril, 1975, p. 279 
haveriam de, por seu turno, suscitar um traçado, visível ainda, onde qualquer outro olhar reencontrará os motivos que sustentam a sua inspeção do mundo? Então aparece um visível em segunda potência, essência carnal ou ícone do primeiro."255

Assim, retomando o que apontava a análise da linguagem, mais do que simplesmente representá-lo, a pintura terá por tarefa reconstituir e prosseguir a dinâmica interna do Ser, refazendo o movimento próprio de criação que descobre nele: caberá à ela explicitar o processo por meio do qual, espontaneamente, ele se configura de modo significativo, se dá a ver e a perceber, estruturando-se como mundo e visibilidade. Afastando-se do modelo da constituição, e de seu pressuposto dualista, também a pintura - como o corpo, o Cogito e o sensível - nos conduzirá à compreensão do Ser como instituição ${ }^{256}$, unidade reflexiva dotada de gênese e significação próprias. Ocupada com a formação de seres visíveis, encarregada de criar visibilidade, ela terá necessariamente que se haver com esse processo de auto-constituição, terá que deparar-se, ainda que contra sua vontade, com os limites da idéia de representação, testemunhando um tipo de organização e de coesão do todo que prescindem de qualquer atividade constituinte externa, síntese espontânea ${ }^{257}$ operante já no sensível, responsável pela produção de um sentido que se faz como mediação entre o subjetivo e o objetivo.

\footnotetext{
Idem, p. 279

256 Explicitaremos esse ponto mais adiante.

257 A noção de síntese passiva é central na Fenomenologia da Percepção, já ali encarregada de assegurar, por meio da temporalidade, a ecceidade do mundo e do sentido. Conforme nossa pesquisa de Mestrado (MOURA, Alex de Campos. Liberdade e situação em Merleau-Ponty: uma perspectiva ontológica, São Paulo: Humanitas, 2010). Como estamos procurando indicar, ela responde por uma das linhas constantes e características da obra de Merleau-Ponty.
} 
Segundo Merleau-Ponty, um dos modos pelo qual a pintura revela essa gênese espontânea do sentido é tornando problemática a cisão entre o real e o imaginário $^{258}$, entre uma matéria tomada como puro ser em si e um sentido entendido como puro para si, oferecendo-se como uma estrutura feita da simultaneidade entre sentido e existência, significação encarnada ao mesmo tempo imanente e transcendente em relação ao seu suporte material: "Os animais pintados na parede de Lascaux ali não estão como lá está a fenda ou o empolamento do calcário. Mas também não estão alhures. Um pouco adiante, um pouco para trás, sustentados por sua massa da qual se servem habilmente, eles irradiam em torno dela sem jamais romperem a sua inapreensível amarra. Achar-me-ia em grande dificuldade para dizer onde está o quadro que olho (...) meu olhar vagueia nele como nos nimbos do Ser $(\ldots)^{m 259}$

A significação de uma obra de arte, indica o filósofo, não pode ser considerada nem uma realidade objetiva, pois então não haveriam múltiplas interpretações e desdobramentos, e nem uma idéia subjetiva, pois então não haveria uma obra de que se pode falar de diversos modos. Nem cativo da matéria, como um objeto, e nem ausente dela, como um pensamento puro, o sentido é algo que irradia em torno da obra sem jamais romper absolutamente com sua estrutura concreta. Como já afirmava a Prosa do Mundo 260 - ao recusar a compreensão sartreana sobre a autonomia do imaginário e do significado frente ao seu suporte concreto $^{261}$-, o sentido é como a lei intrínseca de organização do ${ }^{258}$ MERLEAU-PONTY, Maurice. O Olho e o Espírito. In: Os Pensadores, São Paulo: Abril, 1975, p. 280 ${ }^{259}$ Idem, p. 279, 280

${ }^{260}$ Essa compreensão de sentido presente na análise de Merleau-Ponty sobre a linguagem foi trabalhada no capítulo anterior. Nesse momento, apenas retomamos algumas de suas características.

${ }^{261}$ Para Sartre, o imaginário pressupõe um movimento de negação do em si, uma niilização responsável por 
conjunto, formado pela correlação existencial de seus elementos, espécie de torção ou "deformação" do aparelho significativo disponível capaz de fazê-lo expressar algo novo, estilo operante que enforma a generalidade dada. Compreendido como modulação singular do concreto, ele recusa a distinção entre matéria e forma, entre o empírico e o inteligível, formando-se pela reversibilidade entre eles, facticidade que se configura espontaneamente em significação e significação que se realiza estruturalmente no concreto. O que conduz, como estamos procurando indicar ${ }^{262}$, à própria reformulação desses termos, não mais entidades positivas e separadas, mas momentos sincrônicos e reversíveis, capazes de passar um no outro; do reconhecimento da ecceidade do sentido e de sua estrutura como fusão de matéria e forma, decorre uma outra noção do sujeito e do objeto, reconfigurando o processo criativo e a gênese do sensível.

Modulando o disponível dentro de uma constelação nova, o sentido aparece assim como maneira constante de estruturar e estilizar o dado, articulando-o em um todo coerente: mais do que uma entidade positiva e determinada, ele se configura nas linhas gerais pelas quais uma experiência é singularizada, orientada de modo sistemático ${ }^{263}$. Desse modo, ele não pode estar nem dado, pois ele é uma unidade geral que não pode estar contida em nenhum de seus elementos particulares, e nem ausente, pois ele se forma na estruturação concreta de suas partes ${ }^{264}$. Maneira de configurar os dados, unificação ultrapassar o dado e por estabelecer uma significação inteiramente tributária do para-si, expressão de sua liberdade absoluta (Conforme, por exemplo, O Ser e o Nada, Rio de Janeiro: Vozes, 1999)

${ }^{262}$ Questão central para nossa pesquisa, já a indicamos nos capítulos anteriores, e a retomamos agora.

${ }^{263}$ Esse processo não é posicional, como veremos, porque o dado já é significação, o Ser já é expressivo, estruturado por um Logos operante que nos impede de recair no modelo da constituição.

${ }^{264}$ Mais uma vez, trata-se daquela relação interna entre a parte e o todo, central para as formulações ontológicas de Merleau-Ponty, e sobre a qual nos deteremos mais adiante. 
operante e processual, ele não pode ser exposto ou apreendido diretamente, razão pela qual, mais do que o vermos, nós “(...) vemos com ou segundo ele”, isto é, vemos uma maneira de ver e de tornar visível, criação de visibilidade calcada em um modo de percepção singular, que por sua generalidade formal não pode ser objetivado ou esgotado.

Unidade feita por um princípio interno de organização ${ }^{265}$, o sentido da obra se revela intrínseco a ela, quer dizer, não constituído do exterior por uma consciência. Diferente do objeto, marcado pela identidade estática e externa, a obra se revela detentora de uma dinâmica própria, movimento interno que the assegura unidade e significação próprias. Trata-se não de uma significação positiva ou explícita, tal qual a defendida pela ontologia clássica, mas de uma sistematicidade operante inseparável de sua existência efetiva, composição processual que institui os dados em um todo coerente, antecipando e retomando a multiplicidade de seus elementos dentro de uma unidade dinâmica. Como estamos procurando indicar ao longo da Tese, essa instituição se faz articulando multiplicidade e unidade em uma estrutura temporal, modo de Ser que se auto-configura graças ao seu movimento interno.

A noção de instituição, desenvolvida por Merleau-Ponty especialmente em um curso ministrado no Collège de France entre os anos de 1954 e $1955^{266}$, nos parece fundamental principalmente por condensar a estrutura hibrída que desde o início suas

265 É interessante notar, como estamos procurando indicar e explicitaremos mas adiante, que essa configuração - de uma unidade espontânea estruturada por um princípio interno de organização - é a mesma revelada por outras descrições centrais do filósofo (sobre o tempo, a percepção, a linguagem, por exemplo). E é a mesma pela qual ele define tanto a estrutura (conforme A Estrutura do Comportamento e nossa pesquisa de Mestrado) quanto a instituição (conforme L 'institution, la passivité, Belin, 2003).

266 MERLEAU-PONTY, Maurice. L'institution, la passivité, Berlin, 2003 
descrições apontam. Como apontado anteriormente ${ }^{267}$, por instituição o filósofo designa uma espécie de matriz simbólica ${ }^{268}$ ou evento-matriz ${ }^{269}$, advento de uma ordem ou de um sentido que se formam espontaneamente e não se esgotam em si, abertura de um horizonte que por sua generalidade formal tende a preservar-se e transformar-se. A instituição recusa o modelo da constituição, inviabiliza a subjetividade como instantânea ou negatividade pura, ensinando uma consistência interna ao acontecimento e ao mundo, estruturação espontânea do sentido graças à compossibilidade de seus elementos, não dependente portanto das deliberações do sujeito, oferecendo-se ao contrário como estruturação já em curso, "há prévio" ou visibilidade operante:

“Entendemos então aqui por instituição estes eventos de uma experiência que a dotam de dimensões duráveis, em relação às quais toda uma série de outras experiências terão sentido, formarão uma continuidade pensável ou uma história, - ou ainda os eventos que depositam em mim um sentido, não a título de sobrevivência e de resíduo, mas como apelo a uma continuação, exigência de um porvir."

A instituição, mostra Merleau-Ponty, é unidade que se forma pelo "parentesco" do múltiplo ${ }^{271}$, fundação de uma unidade lateral e indireta cuja gênese se faz por seu arranjo concreto, recusando simultaneamente a noção do sujeito como posição e do

267 Conforme o capítulo anterior.

268 MERLEAU-PONTY, Maurice. L'institution, la passivité, Berlin, 2003, p. 45

269 Idem, p. 44

${ }^{270}$ Idem, p. 124: “On entendait donc ici par institution ces événements d'une expérience qui la dotent de dimensions durables, par rapport auxquelles toute une série d'autres expériences auront sens, formeront une suite pensable ou une histoire, - ou encore les événements qui déposent em moi un sens, non pas à titre de survivance et de résidu, mais comme appel à une suite, exigence d'un avenir. " [tradução nossa]

271 Idem, p. 36 
objeto como posto. Unidade auto-configurada, que tende a se afirmar e a prosseguir por seu próprio movimento interno de transformação, a instituição funda as linhas gerais do porvir, estabelece os contornos principais de uma experiência, incapaz contudo, enquanto abertura, de determiná-la. Assegurando a passagem entre a singularidade do diverso e a organicidade do todo, ela conserva a especificidade dos termos, explicitando uma fusão não identitária que vai buscar na temporalidade seu fundamento ${ }^{272}$ : "O tempo é o modelo mesmo da instituição: passividade-atividade, ele continua, porque ele foi instituído, ele difunde-se, ele não pode deixar de ser, ele é total porque parcial, ele é um campo"273. Compreendida como instituição em estado nascente ${ }^{274}$, a temporalidade sustenta essa unidade aberta e essa síntese espontânea ${ }^{275}$ próprias à experiência e à história, unifica o diverso pela abertura que instaura em cada singularidade. Ela assegura, assim, uma reversibilidade orgânica entre o uno e o múltiplo ${ }^{276}$, tipo de Ser que se auto-configura por sua estrutura diacrítica.

Trata-se, pois, da mesma configuração ontológica que nossas diversas

${ }^{272}$ Conforme indicado no capítulo anterior.

273 MERLEAU-PONTY, Maurice. L'institution, la passivité, Berlin, 2003, p. 36: "Le temps est le modele même de l'nstitution: passivité-activité, il continue, parce qu'il a eté institué, il fuse, il ne peut pas cesse d'être, il est total parce qu'il est partial, il est un champ." [tradução nossa]

274 Idem, p. 36

275 Procuramos trabalhar essa compreensão da temporalidade como unidade aberta e síntese espontânea em nossa pesquisa de Mestrado (MOURA, Alex de Campos. Liberdade e situação em Merleau-Ponty: uma perspectiva ontológica, São Paulo: Humanitas, 2010).

276 Em nossa leitura, a temporalidade é fundamental na obra de Merleau-Ponty, e central na configuração de sua ontologia. Essa questão, que retomaremos ao final do capítulo, foi indicada ao longo deste capítulo e dos anteriores. Procuramos mostrar essa centralidade do tempo e sua significação ontológica em nossa pesquisa de Mestrado (MOURA, Alex de Campos. Liberdade e situação em Merleau-Ponty: uma perspectiva ontológica, São Paulo: Humanitas, 2010). 
análises têm encontrado ${ }^{277}$, uma outra designação para esse Ser que se estrutura por gênese espontânea, pela passagem interna que descortina entre o subjetivo e o objetivo, ajudando a confirmar nossa hipótese de que uma das caraterísticas centrais da ontologia merleau-pontyana é a explicitação do Ser como articulação originária de sentido e existência, unidade que se faz por diferenciação interna, sentido temporal estruturado pela abertura de seu devir.

Como afirma o filósofo, é justamente a instituição - enquanto cofiguração ontológica nova - a estrutura capaz de dar conta do sentido revelado pela pintura, do modo de "presença do todo nas partes" que ela explicita e que recusa tanto a gratuidade quanto a finalidade puras, afirmação de uma lógica concreta, operante, que se cria e recria "caminhando"278. Assim como um acontecimento, uma grande obra já contém, de um certo modo, tudo o que foi dito e o que se pode dizer sobre ela, pois longe da positividade do objeto, seu estabelecimento funda uma tradição, inaugura ou institui uma "onda temporal", isto é, abre e conserva um horizonte de passado e de porvir, assegura a constância de uma maneira singular de unificar a multiplicidade, de organizar os diferentes momentos em um sentido constante. Ela não é portanto objeto, mas instituição:

“Em certo sentido, tudo o que se pode dizer e que se disser da Revolução Francesa sempre esteve, está desde agora nela, nessa vaga que se desenhou no fundo dos fatos parcelados com sua escuma de passado e sua crista de futuro, e sempre olhando

277 Conforme indicado nos capítulos anteriores e conforme nossa pesquisa de Mestrado (MOURA, Alex de Campos. Liberdade e situação em Merleau-Ponty: uma perspectiva ontológica, São Paulo: Humanitas, 2010).

278 MERLEAU-PONTY, Maurice. L'institution, la passivité, Belin, 2003 , p. 78 
melhor como foi que ela se fez é que se dão e se darão dela novas representações (...) o excesso e a espessura do sentido, a textura que lhe preparava um longo futuro, esta maneira ativa de ser, esta possibilidade que ele descobre na obra, esse monograma que nela encontra, fundamentam uma meditação filosófica." 279

O sentido da obra não é um objeto ou uma idéia porque ele se forma como unidade dinâmica, concreta e auto-regulada, temporalidade singular expressa por um modo particular de compor o diverso, operando por horizontes que direcionam seus desdobramentos e asseguram sua autonomia. Contra a idéia de identidade e de objetividade, ela se revela como modo de ser configurado por um processo interno em que simultaneamente se confirma e se transforma. Ao recorrer à temporalidade, o filósofo nos remete a um tipo de unidade aberta que se forma por auto-diferenciação, movimento diacrítico que se unifica através da dissonância de seus elementos ${ }^{280}$ e não por algum agente externo. Contra o modelo da constituição, e da positividade ontológica por ele implicada, trata-se de uma unidade que se forma a partir da diferença e da transformação, que se afirma nelas - confirmando a configuração do Ser já indicada nas análises anteriores. Internamente diferenciada, a obra, como o sensível e o corpo aos quais se mantém vinculada, revela um tipo de geratividade estrutural, movimento de devir e auto-

279 MERLEAU-PONTY, Maurice. O Olho e o Espírito. In: Os Pensadores, São Paulo: Abril, 1975, p. 292

280 Embora nem sempre considerada por boa parte de seus comentadores, a questão da temporalidade nos parece ser central na obra de Merleau-Ponty. Procuramos mostrá-lo em nossa pesquisa de Mestrado, explicitando sua significação ontológica e seu papel fundamental na maior parte de suas descrições. Ao longo deste capítulo e dos anteriores, essa questão vem sendo gradualmente trabalhada.

Sobre uma análise que busca inserir a compreensão merleau-pontyana sobre a tenporalidade em um contexto mais amplo, mostrando seu diálogo com outros autores, é possível ver: MULDOON, Mark S. Tricks of time: Bergson, Merleau-Ponty and Ricoeur in Search of time, Self and Meaning, Duquesne University Press, 2006 
constituição que nasce de seu caráter dissonante. Ela não é informe ou estática, mas processo de transformação, dinâmica e abertura orientadas, contribuindo, como veremos mais adiante, para a reformulação das noções de sujeito e de criação.

Feito por essa diferenciação que assegura a unidade, o sentido se afirma como subversão e transformação do dado, passagem interna que o generaliza e transforma, remetendo-o à totalidade em curso. Ele realiza assim, espontaneamente, um movimento de gênese e de articulação, referência da parte à uma unidade mais ampla, do particular a um sentido mais geral ${ }^{281}$, por meio da referência interna que descobre entre o atual e o possível, entre o presente e seus horizontes ${ }^{282}$. Isto é, ele opera não de modo posicional, mas graças à estrutura relacional que mantém entre os termos, revelando-os não como entidades positivas, mas como diferentes momentos da reversibilidade que funde unidade e multiplicidade, a forma e o concreto. Cada um, portanto, apresentando-se como diferenciação ou abertura de seu outro, o horizonte como uma dilatação e transformação do presente, o imaginário como abertura e metamorfose intrínsecas ao concreto - conforme já pudemos apontar no capítulo anterior. Assim compreendido, como unidade dinâmica configurada por auto-diferenciação, o sentido confirma mais uma vez o Ser latente nas descrições de Merleau-Ponty, estrutura única que recusa as dualidades, operando por

${ }^{281}$ Como indicado, trataremos de modo mais detido da relação entre a parte e o todo mais adiante.

${ }^{282}$ Nesse sentido, como apontado acima e retomaremos mais adiante, é preciso compreender o imaginário e os horizontes não como entidades positivas, mas como diferenciações, aberturas estruturais do real e do presente. Eles se assentam, assim, nessa estrutura ontológica que estamos procurando circunscrever, e que se faz não mais pela oposição dos termos, mas por sua articulação no interior de uma unidade diacrítica, confirmando nossa hipótese sobre um projeto de dessubstancialização ontológica empreendido por MerleauPonty. 
reversibilidade e distanciamento interno. ${ }^{283}$

É justamente dessa comunicação recíproca entre os termos, movimento espontâneo que liga um ao outro, que a obra extrai sua textura e profundidade, revestindose de um horizonte e de um imaginário próprios, dados na estrutura aberta de sua organização concreta, pré-figuração de possíveis estabelecida pela dinâmica efetiva de sua existência. Como afirma Merleau-Ponty, o problema do imaginário não está em ser uma esfera transcendental, campo autônomo e subjetivo, mas justamente em ser indissociável da realidade, portador dessa "quase presença e [dessa] visibilidade iminente" que o tornam "quase" atual. Atados pela idéia de diferença, o real e o possível, o dado e a criação, tornam-se agora indissociáveis, revertem-se um no outro, transitam entre si sem necessidade de um terceiro termo para compô-los. Unidade espontânea e reflexiva - como a do corpo e a do sensível ${ }^{284}$ - que também a pintura desdobra:

"[A imagem, o desenho e o quadro] São o interior do exterior e o exterior do interior, que a duplicidade do sentir torna possíveis, e sem os quais nunca se compreenderão a quase-presença e a visibilidade iminente que constituem todo o problema do imaginário."285

Desdobrando a estrutura reversível do Ser, o pintor permanece e cria no interior do sensível e de sua estrutura dialógica, "trabalha com seu corpo" e não como um

${ }^{283}$ Conforme indicado acima e continuaremos a explicitar no decorrer do capítulo. Essa questão, central em nossa pesquisa, foi também tratada nos capítulos anteriores.

${ }^{284}$ Como indicamos acima e explicitaremos mais adiante, trata-se de uma mesma estrutura ontológica, um mesmo tipo de unidade diacrítica, presente em diversas descrições do filósofo, como na temporalidade, na percepção, na linguagem... articulando suas proposições em uma direção comum.

285 MERLEAU-PONTY, Maurice. O Olho e o Espírito. In: Os Pensadores, São Paulo: Abril, 1975, p. 280 
espírito separado, isto é, participa da fusão vidente-visível que relativiza a autonomia dos termos $^{286}$. Sua criação, portanto, mantém-se inscrita nessa passagem espontânea que faz do possível uma diferenciação pré-figurada pelo atual, do novo uma abertura intrínseca ao dado. Esse imaginário "quase" atual revela-se pois como a dimensão iminente ou operante do real, invisível ${ }^{287}$ em vias de tornar-se visível; o real, como a dimensão atual ou presente do possível, visível em vias de tornar-se invisível. Ambos, portanto, não mais que diferenciações dessa estrutura única, desse Ser e dessa visibilidade em que se torna impossível distinguir o atual e o possível, o dado e a criação. A análise do imaginário feita por Merleau-Ponty confirma, assim, a constituição do Ser como unidade que sincroniza o ativo e o passivo. Como já mostravam a análise do corpo e do sensível, trata-se de uma estrutura ontológica única em que a dimensão atual é sustentada por um horizonte de latência e de profundidade, e a dimensão passiva por um campo de ação e iminência compreensão que será retomada e aprofundada também em O Visível e o Invisível, como veremos no próximo capítulo. Não há mais ruptura completa, e a passagem de uma à outra, responsável pelo processo de criação, não é mais dependente das deliberações do sujeito; ao contrário, ela é agora estrutural, inscrita na constituição interna do Ser. Entre o real e o

${ }^{286}$ Como afirma Merleau-Ponty, atado à estrutura híbrida do corpo e do sensível, o “(...) imaginário está muito mais perto e muito mais longe do atual": perto, na medida em que ele é um "diagrama do atual em meu corpo", sua "essência carnal" exposta pela primeira vez e revertida em expressão; longe, contudo, enquanto permanece um "análogo" apenas por meio dessa mediação do corpo, isto é, vinculado à percepção singular que o enforma. O imaginário, assim, se descobre relacionado com o trabalho singular de apreensão do atual realizado pelo corpo; enquanto o atual se descobre relacionado à modulação perceptiva calcada no imaginário. (MERLEAU-PONTY, Maurice. O Olho e o Espírito. In: Os Pensadores, São Paulo: Abril, 1975, p. 280)

287 Como estamos indicando, e explicitaremos mais adiante, a questão do invisível - central em $O$ Visível $e$ Invisivel - já aparece aqui, fundamental para a formulação ontológica proposta por Merleau-Ponty. 
imaginário, a transição é formativa, há apenas uma unidade internamente diferenciada e reversível que não pode ser negada por uma atividade constituinte pura ${ }^{288}$. Assim, se o sentido não é mais objeto engendrado do exterior por um sujeito desengajado, se o imaginário não é mais transcendente em relação ao real, e se ambos se revelam enfim inseparáveis de sua existência efetiva, é pelo reconhecimento dessa estrutura híbrida, desse Ser unitário que põe em suspenso a compreensão do mundo como objeto posto e do homem como atividade constituinte.

${ }^{288}$ Novamente se afastando de Sartre, Merleau-Ponty propõe uma espécie de reversibilidade estrutural entre o real e o imaginário, afirmando uma constituição recíproca entre eles. Isso implica que o gesto de criação, o movimento significativo, permanece dotado de uma certa passividade, tributário de algo que lhe advém do real e da situação em que se encontra. Para Sartre, ao contrário, a autonomia do imaginário é equivalente à autonomia da liberdade, expressão da pura atividade subjetiva que se revela em um processo de significação que nada deve ao em-si.

Sobre a relação entre Merleau-Ponty e Sartre, ver, por exemplo: STEWART, Jon (ed). The Debate between Sartre and Merleau-Ponty, Northwestern University Studies in Phenomenology \& Existential Philosophy, 1998 
3. Mundo e criação

No que se refere ao novo estatuto implicado para o mundo, cabe reconhecer - como já apontado pela análise do corpo visível-vidente e da reflexividade do sensível que ele recusa a categoria de objeto, aparecendo como instituição, unidade aberta e autoconfigurada, que se estrutura pelo caráter diacrítico de seus elementos e pela relação estrutural existente entre a parte e o todo. O mundo sensível deixa de ser construção ou representação para assentar-se ele também nesse Ser unitário e diacrítico, totalidade autoregulada, que, por seu caráter processual e reflexivo, permanece aberta. Enquanto articulação interna, o mundo é unidade; enquanto devir e diferenciação, é abertura. Mais ainda, como veremos, ele os é ao mesmo tempo, a multiplicidade de suas manifestações sendo precisamente o que assegura a unidade de seu movimento e vice-versa, havendo entre suas dimensões uma constituição recíproca. Híbrido, o mundo não pode nem se reduzir à forma do objeto ${ }^{289}$, pois permanece ativo e já significativo, e nem à de causa, pois

289 Em uma outra abordagem, relativa à questão da intersubjetividade, Bonan também mostra que a pintura recusa a compreensão do mundo como objeto. Conforme BONAN, Ronald. L'institution intersubjective comme poétique générale v. 2, L’Harmattan, 2001, p. 63 
permanece passivo e incompleto. Ele é - como o corpo e o Cogito ${ }^{290}$ - unidade aberta, síntese temporal responsável por estabelecer as linhas gerais do todo.

É por isso que ele não pode ser nem inteiramente determinante e nem inteiramente determinado em relação ao sujeito. Por sua unidade e coesão, ele é responsável por motivar ${ }^{291}$ os atos singulares que lhe respondem, pré-figurar formas gerais para o porvir, possíveis privilegiados por uma certa situação. Enquanto abertura e diferenciação, estrutura geral do processo, ele permanece contudo incapaz de determinar algum desses atos em particular ${ }^{292}$, de esgotar o horizonte de possibilidades e o movimento de mudança. Se por um lado, o mundo oferece ao olhar já uma certa estruturação, um conjunto de linhas operantes, por outro essa configuração permanece processual, incapaz de causar os gestos singulares que lhe respondem.

Totalidade aberta, estrutura feita por sua própria diferenciação, o mundo confirma esse Ser que se realiza como fusão entre o múltiplo e a unidade, garantia simultânea da reciprocidade e da autonomia entre os termos. Como unidade geral de um conjunto diacrítico, seu sentido não pode se esgotar em nenhum de seus elementos em particular, implicando, ao mesmo tempo, a modulação e a liberdade desses elementos:

${ }^{290}$ Conforme indicado acima.

291 A noção de motivação é de grande importância em Merleau-Ponty, respondendo por uma relação entre a situação e a liberdade, o dado e o novo, que não é nem determinante e nem gratuita. Transição interna que ao mesmo tempo unifica e preserva a consistência dos termos. Conforme a Fenomenologia da Percepção e nossa pesquisa de Mestrado (MOURA, Alex de Campos. Liberdade e situação em Merleau-Ponty: uma perspectiva ontológica, São Paulo: Humanitas, 2010).

292 Essa compreensão do mundo e de seu caráter simultaneamente motivador e não determinante, é longamente trabalhada por Merleau-Ponty na Fenomenologia da Percepção. Conforme nossa pesquisa de Mestrado (MOURA, Alex de Campos. Liberdade e situação em Merleau-Ponty: uma perspectiva ontológica, São Paulo: Humanitas, 2010). 
cada uma de suas partes se descobre simultaneamente pré-estruturada (enquanto expressão do todo) e aberta (enquanto transformação desse todo). É na constituição recíproca e interna entre a parte e o todo, entre a diferença e a unidade, que se situa tanto a ecceidade quanto a abertura do mundo, ação e passividade correlatas. Significação e transformação concomitantes, o mundo merleau-pontyano reconfigura a questão - central para a fenomenologia ${ }^{293}$ - sobre a relação entre a parte e o todo, propondo um modo de $\operatorname{Ser}^{294}$ cuja estrutura escapa tanto à cisão quanto à redução de um ao outro. É essa articulação interna e dialógica intrínseca ao mundo que a pintura testemunha: como afirma Merleau-Ponty, o mundo do pintor é “(...) um mundo quase louco, pois que é completo sendo, entretanto, meramente parcial. A pintura desperta e eleva à sua última potência um delírio que é a própria visão, já que ver é ter à distância, e que a pintura estende essa bizarra posse a todos os aspectos do Ser, que de alguma maneira devem fazer-se visíveis para entrar nela." 295

A pintura, e de modo mais geral a visão ${ }^{296}$, ensina um modo de ser em que a

${ }^{293}$ A relação entre a parte e o todo, entre o noema e a noese, é uma questão central para Husserl, fundamental no próprio estabelecimento do campo de investigação próprio à fenomenologia. A esse respeito ver: MOURA, Carlos Alberto Ribeiro de. Racionalidade e crise. São Paulo: Discurso Editorial / Edufpr, 2001, especialmente seu ensaio Exame de paternidade.

Conforme indicado no capítulo anterior, sobre essa questão relativa à relação entre a parte e o todo em Merleau-Ponty, autores como Dillon (DILLON, M.C. Merleau-Ponty's Ontology, Northwestern University Press, 1997) e Thierry (THIERRY, YVES. Du corps parlant, Le langage chez Merleau-Ponty, OUSIA, 1987), por caminhos diversos, tratando do tema da linguagem, apontam para a existência de uma relação entre a particular e o geral calcada na reciprocidade.

${ }^{294}$ Em nossa leitura, julgamos que desde o início a filosofia de Merleau-Ponty busca estabelecer uma passagem entre fenomenologia e ontologia, partindo da primeira em direção à segunda. Retomaremos essa questão ao final do capítulo. Trabalhamos esse tema em nossa pesquisa de Mestrado (MOURA, Alex de Campos. Liberdade e situação em Merleau-Ponty: uma perspectiva ontológica, São Paulo: Humanitas, 2010).

${ }^{295}$ MERLEAU-PONTY, Maurice. O Olho e o Espírito. In: Os Pensadores, São Paulo: Abril, 1975, p. 281

${ }^{296}$ Como indicado acima, retomaremos essa questão sobre a visão mais adiante. 
parte já é expressiva do todo, em que a perspectiva perceptiva, por sua estrutura mesma, se dilata e generaliza em um sentido mais amplo. Opondo-se ao modelo clássico de constituição - como apontamos acima e explicitaremos mais adiante - a visão não é posição, mas abertura, transcendência, distensão em direção ao que não é ela, síntese por horizontes e não por assimilação. O visto não é posto, mas alcançado em sua ecceidade, por um processo de diferenciação que unifica os termos sem identificá-los ${ }^{297}$ : "Ele [o pintor] aceita, com todas as dificuldades, o mito das janelas da alma: cumpre que aquilo que é sem lugar esteja adstrito a um corpo: além disso, que seja por ele iniciado a todos os outros e à natureza. É preciso tomar ao pé da letra aquilo que a visão nos ensina: que por ela tocamos o sol, as estrelas, estamos ao mesmo tempo em toda parte." ${ }^{298}$

A passagem da parte ao todo, do singular ao mundo e ao outro, deixa de ser empreendida por uma consciência, seja ela constituinte como a cartesiana ou transcendental como a husserliana. Por meio da visão, da estrutura reflexiva do corpo e do sensível, o sujeito se reconhece inserido em uma dinâmica espontânea que não provém de si e não se esgota nele; o "objeto" ao qual acede por um de seus perfis se forma através do movimento e da articulação próprios a esse perfil, pelo imaginário concreto que resveste cada singularidade, e não por um ato deliberado do sujeito. A "posse" empreendida pela visão não é assimilação, mas abertura e saída de si, transição do parcial à unidade que é própria à estrutura do mundo e não apenas da consciência. Um mundo que é, portanto, instituição, gênese espontânea de uma unidade aberta e dissonante, com horizontes

${ }^{297}$ Como será explicitado mais adiante.

298 MERLEAU-PONTY, Maurice. O Olho e o Espírito. In: Os Pensadores, São Paulo: Abril, 1975, p. 
próprios, diferenças, movimento interno que a dota de profundidade e textura. Confirmando o que vinhamos indicando antes, a análise do mundo reafirma o fato de que a transição entre os termos tradicionalmente cindidos pela ontologia clássica não depende mais de uma subjetividade insular, pois ela é agora originária na estrutura do Ser - reversibilidade espontânea, operante na visão, no corpo, no Cogito e no mundo sensível:

“[A pintura] dá existência visível àquilo que a visão profana acredita invisível, faz que não tenhamos necessidade de 'sentido muscular' para termos a voluminosidade do mundo. Esta visão devoradora, para além dos 'dados visuais', abre para uma textura do Ser cujas mensagens sensoriais discretas são apenas as pontuações ou as cesuras,e que o olho habita como o homem habita sua casa." ${ }^{299}$

É essa reversibilidade espontânea, garantia da ecceidade do sentido do Ser, que assegura o volume e a profundidade intrínsecas ao mundo, endossando uma totalidade que se faz pela diferença de seus termos constituintes, pela relação de suas partes, nem idênticas e nem alternativas. Para Merleau-Ponty, diferente das noções de altura e largura, que supõem a completa determinação do objeto, a profundidade se forma pela convivência conflituosa das coisas, pelo fato de cada uma delas se afirmar como tentativa de sobreporse às demais, de capturar para si o olhar, em um movimento singular que, ao mesmo tempo que nega a totalidade, a confirma como solo e fundo ${ }^{300}$ de seu ato. Estrutura que se constrói internamente, graças ao fato de cada elemento ser simultaneamente uma confirmação e 299 Idem, p. 281

${ }^{300}$ Reencontra-se assim a discussão sobre a relação entre figura e fundo, trabalhada por Merleau-Ponty desde o início de sua obra, especialmente por sua apropriação da Gestalt. Conforme a Estrutura do Comportamento e a Fenomenologia da Percepção. Conforme nossa pesquisa de Mestrado (MOURA, Alex de Campos. Liberdade e situação em Merleau-Ponty: uma perspectiva ontológica, São Paulo: Humanitas, 2010). 
uma diferenciação do todo, a profundidade desdobra o movimento de unificação e autoconfiguração do Ser operante por conflito e dissonância. Feita pela reversibilidade entre o parcial e o geral, revelando seu vínculo e recíproca constituição, ela testemunha o surgimento imotivado do mundo e do visível, gênese estrutural do sentido por meio do movimento intrínseco à configuração ontológica que faz da parte uma diferenciação do todo, sua modalização, e do todo uma diferenciação da parte, seu horizonte; momentos diversos dessa unidade que se forma e preserva pela reversibilidade de seus termos:

“É a sua exterioridade conhecida no envolvimento delas e a mútua dependência delas na sua autonomia (...) Assim compreendida, a profundidade é mais propriamente a experiência da reversibilidade das dimensões, de uma 'localização global' onde tudo está a um só tempo, cuja altura, largura e distância são abstratas, de uma voluminosidade que se exprime com uma palavra dizendo que uma coisa está lá. Quando Cézanne procura a profundidade, é essa deflagração do Ser que ele procura, e ela está em todos os modos do espaço, e na forma igualmente."301

Surgimento imotivado, presença irredutível, essa síntese espontânea operante no mundo, generalizada no sensível, acaba por limitar os poderes do sujeito, não por determinar seus atos, mas por lhe oferecer a forma geral de todo processo de gênese e de formação do sentido, dinâmica originária que seu gesto singular retoma mas não engendra. Ao invés de uma consciência constituinte, o que a atividade do pintor revela é

${ }^{301}$ MERLEAU-PONTY, Maurice. O Olho e o Espírito. In: Os Pensadores, São Paulo: Abril, 1975, p. 293 
uma subjetividade que não se distingue inteiramente da estrutura configuradora de seu objeto, que não se furta a um modo de articulação já existente, inscrito em uma percepção e em uma visão que o abrem ao que não é ele, a uma síntese geral. Ele não pode portanto manter-se mais como um puro agente, pois é também agido, passivo diante daquilo que se oferece a ele e captura parte de sua atividade: "Entre ele [o pintor] e o visível, os papéis se invertem inevitavelmente". Se o sensível é ele próprio ativo, o sujeito que o percebe e recria do interior revela-se necessariamente aberto e vulnerável, participante do movimento mais amplo por meio da qual a gênese do visível se faz. O sujeito não é mais pura atividade constituinte. E a criação não é mais posição, mas retomada e transformação.

Se, por um lado, o reconhecimento dessa atividade interna ao mundo pode parecer privar o sujeito de seus direitos e privilegiar o objeto, por outro, é ela quem assegura uma dimensão singular e subjetiva em cada ato que o exprime. Assim como a síntese espontânea do sensível impede a obra de ser simples produto da consciência, ela também a impede de ser simples decalque: uma obra não pode apenas reproduzir o mundo porque, como vimos, ele por si já é uma estrutura dinâmica, dissonante e processual. Como todo gesto humano, o trabalho do artista desdobra o processo inesgotável de autodiferenciação do Ser; continua, como metamorfose, a metamorfose que se passa no mundo, potencializando seu caráter aberto. Se o próprio "objeto" é não idêntico a si, internamente diferenciado, a obra que o exprime escapa a qualquer forma de determinidade completa, atuando no espaço possível intrínseco a ele. A criação deixa de operar com um sujeito e um objeto puros, situando-se nesse passagem ou diferenciação interna que reune 
o diverso e abre o porvir.

Merleau-Ponty recusa, desse modo, tanto a noção de obra como representação da realidade, quanto dela como ato absolutamente livre. Ambas reiteram a cisão entre o subjetivo e o objetivo, fazem da criação um processo centrado na exterioridade dos termos, ora tendendo para o sujeito, ora para o objeto, reiterando os moldes da ontologia clássica e seu pressuposto dualista. Articulando internamente os termos, a reflexividade do sensível recusa tanto uma quanto outra. Do reconhecimento de que o real e o imaginário são inseparáveis na unidade do Ser, de que o sensível é produtivo e capaz de transformar-se constantemente, gerando sentido por sua organização concreta, decorre um modo de criação que desconhece a ruptura entre o concreto e a significação, realizando-se no intermeio entre eles.

A criação não é mais constituição, não pressupõe mais a distinção ontológica entre homem e mundo, porque ela é agora passagem, transformação ou metamorfose inscritas na estrutura desse Ser feito pela reversibilidade entre o atual e o latente, entre o real e o possível. Como dirá Merleau-Ponty, ela é um "nascimento continuado", o que não significa corte, mas justamente transição e elaboração, formação gradual entretecida na troca entre o virtual e o efetivo: "Diz-se que um homem nasceu no momento em que aquilo que, no fundo do corpo materno, não passava de um visível virtual torna-se ao mesmo tempo visível para nós e para si. A visão do pintor é um nascimento continuado". A criação, como o nascimento, é o processo de dar à luz e tornar visível, revelando algo já latente ou já em processo de configuração, operando a passagem do possível ao atual, do dado ao 
novo, sem qualquer mediação externa.

Não há portanto nela nenhuma ruptura completa, impossível distinguir o sujeito e o objeto, a situação e a abertura, pois há apenas um único Ser que se recria constante e necessariamente. Como afirma Merleau-Ponty em Sobre a fenomenologia da linguagem só há finalidade no sentido em que Heidegger a compreendia: “(...) como tremor de uma unidade exposta a contingência e recriando-se infatigavelmente" ${ }^{302}$. A configuração ontológica proposta por Merleau-Ponty encontra a criação como estrutura originária do Ser; metamorfose feita por dissonância interna, ela opera como diferenciação e singularização estruturais de uma generalidade mais ampla - como a análise de O Visível e o Invisível, no capítulo seguinte, ajudará também a explicitar. Assim compreendida, e estrutura do Ser propõe um modelo de criação que prescinde da cisão entre subjetivo e objetivo, abdica de qualquer instância constituinte autônoma e assegura uma gênese interna e espontânea:

"Cumpre que ele [o pintor] confesse (...) que a mesma coisa está lá no coração do mundo e cá no coração da visão, a mesma ou, se se fizer questão, uma coisa semelhante, porém segundo uma similitude eficaz, que é parenta, gênese, metamorfose do ser em sua visão. É a própria montanha que, lá de longe, se mostra ao pintor, é a ela que ele interroga com o olhar" ${ }^{303}$

Trazendo para o primeiro plano suas implicações ontológicas, a pintura torna explícito esse processo de auto-constituição do Ser, expressão que tenta retomar o movimento por meio do qual ele se faz visível, unidade e sentido. Questão central na

${ }^{302}$ MERLEAU-PONTY, Maurice. Sur la phénoménologie du langage. In: Signes. Gallimard, 1960, p. 158

${ }^{303}$ MERLEAU-PONTY, Maurice. O Olho e o Espírito. In: Os Pensadores, São Paulo: Abril, 1975, p. 281 
ontologia de Merleau-Ponty, a pintura expõe, contra a compreensão da criação como artifício, a existência dessa gênese espontânea, reflexividade e "similitude eficaz" que se fazem pela transição estrutural dos termos, configuração interna do sentido. Ela ajuda, assim, a revelar o mundo sensível como uma espécie de matriz simbólica, instituição que pré-figura as linhas gerais de toda gênese e de toda criação: "Que lhe pede ele [o pintor] exatamente? Pede-lhe [à montanha] desvelar os meios, apenas visíveis, pelos quais ela se faz montanha aos nossos olhos. Luz, iluminação, sombras, reflexos, cor (...) não são inteiramente seres reais: como os fantasmas, só têm existência visual. Não estão, mesmo, senão no limiar da visão profana, e comumente não são vistos. O olhar do pintor perguntaIhes como é que eles se arranjam para fazer que haja subitamente alguma coisa, e essa coisa, para compor esse talismã do mundo, para nos fazer ver o visível."304

Enfim, de um modo ainda mais claro que as outras artes, a pintura explicita essa estrutura ontológica que se afirma como unidade diacrítica - reencontrando a estrutura da percepção, da linguagem, do tempo ${ }^{305}$-, processo espontâneo de configuração do sentido, não como entidade positiva e determinada, mas como forma geral, imaginário concreto que estabelece as linhas gerais do porvir. Trazendo à luz a reflexividade do sensível, ensinando a auto-geração do mundo e do visível, seu trabalho explicita e prolonga o processo por meio do qual o Ser se faz visibilidade, cria o novo sem romper seu caráter unitário; explicita a inserção do sujeito e do objeto na estrutura cambiável da visão,

304 Idem, p. 281

305 Conforme indicado nos capítulos anteriores e conforme nossa pesquisa de Mestrado (MOURA, Alex de Campos. Liberdade e situação em Merleau-Ponty: uma perspectiva ontológica, São Paulo: Humanitas, 2010). 
confirmando a sincronicidade entre ação e passividade. Explicita, enfim, a insuficiência da ontologia clássica, e a necessidade de se conceber um Ser ao mesmo tempo único e múltiplo, auto-gerado por diferenciação interna que confirma a unidade do processo. Ela nos remete portanto àquela questão sobre o "há prévio" que a ciência se esforça em ignorar, tornado agora central, conduzindo às questões sobre a pré-constituição do sentido e sobre a gênese espontânea do mundo, temáticas centrais, como veremos no capítulo seguinte, também em O Visível e o Invisível.

Nos parece, por isso, que é justamente enquanto revelação desse Ser instituinte que a pintura adquire a importância que Merleau-Ponty lhe atribui. Apta a recusar os dualismos do pensamento clássico, ela revela a sincronicidade dos termos desdobrando a dinâmica espontânea e unitária que reconhece no mundo, confirmando a eceidade do sensível e a existência concreta do sentido:

'O 'instante do mundo' que Cézanne queria pintar, e que de há muito já passou, suas telas continuam a no-lo lançar, e sua montanha ... faz-se e refaz-se de um extremo a outro do mundo, de outro modo, mas não menos energicamente, do que na rocha dura acima de Aix (...) Essência e existência, imaginário e real, visível e invisível, a pintura baralha todas as nossas categorias ao desdobrar seu universo onírico de essências carnais, de semelhanças eficazes, de mudas significações." 306

\footnotetext{
${ }^{306}$ MERLEAU-PONTY, Maurice. O Olho e o Espírito. In: Os Pensadores, São Paulo: Abril, 1975, p. 283
} 
4. A cor, a linha e a gênese do visível

"A arte não é construção, artifício, relação industriosa a um espaço e a um mundo de fora. É verdadeiramente o 'grito inarticulado' de que fala Hermes Trimegisto, 'que parecia a voz da luz'. E, uma vez aí, ele desperta na visão ordinária das potências adormecidas um segredo de preexistência."307

A pintura, na medida em que desdobra o processo de auto-formação do sensível, significando graças à sua participação na expressividade já operante no mundo, revela a gênese espontânea do sentido e do visível, manifesta a estrutura própria ao Ser circunscrito pela ontologia de Merleau-Ponty. "O visível no sentido profano esquece as suas premissas, repousa inteiro numa visibilidade inteira que é preciso recriar, e que liberta os fantasmas cativos nele (...) em todo caso, a interrogação da pintura visa a essa gênese secreta e febril das coisas em nosso corpo" ${ }^{\text {"308 }}$. Como vimos, ela não opera como ${ }^{307}$ Idem, p, 294

${ }^{308}$ Idem, p. 282 
constituição ou cópia, mas como esforço de prosseguir o movimento por meio do qual o Ser se constitui, se estrutura como visibilidade, significação concreta e aberta dada à percepção. Uma vez que esse movimento prescinde de nossas decisões deliberadas, se manifesta tão logo nos situamos no mundo e assim se dissimula na forma da cotidianeidade, cabe à ela ajudar em sua desocultação, revelando aquilo que se faz nos homens sem seu conhecimento explícito ${ }^{309}$, tomando o problema da gênese interna ao Ser como sua questão principal. Nesse sentido, é possível supor o recurso de Merleau-Ponty à pintura como uma espécie de suspensão ${ }^{310}$ : assim como a percepção se dissimula para nos dar o percebido, a linguagem a significação, há uma "visibilidade" operante que se oculta por sob o visível, em relação à qual é preciso romper os laços mais imediatos, a fim de reconhecer seu nascimento imotivado e espontâneo. Como já ocorria desde a Fenomenologia da Percepção ${ }^{311}$, a redução para Merleau-Ponty deve mostrar precisamente a impossibilidade de sua realização completa, revelando a gênese espontânea com a qual se depara, seja do percebido, do sentido ou do visível; explicitação de uma estrutura de

309 Idem, p. 282

310 Trata-se, pois, do mesmo papel que a pintura desempenhava em relação ao estudo de Merleau-Ponty sobre a linguagem, também ali encarregada de realizar uma redução capaz de revelar a dimensão operante e espontaneamente significativa dissimulada pela cotidianeidade e pelo pensamento objetivo. Conforme indicado no capítulo anterior.

Como já ocorria na Fenomenologia da Percepção (conforme nossa pesquisa de Mestrado), o sentido em que Merleau-Ponty faz uso da "redução" é bastante diverso de sua matriz husserliana. Tanto no estudo de 1945 quanto agora, como veremos, ela se torna um método indireto encarregado de revelar, ao invés do domínio dos puros noemas, justamente o seu avesso: a inseparabilidade entre essência e existência, entre a ordem do sentido e a da facticidade. Ao se deparar com a impossibilidade de se realizar completamente, de oferecer seu objeto como pura idealidade, ela nos conduz a um campo pré-objetivo que antecede o corte entre sujeito e objeto.

311 Conforme nossa pesquisa de Mestrado (MOURA, Alex de Campos. Liberdade e situação em MerleauPonty: uma perspectiva ontológica, São Paulo: Humanitas, 2010). 
$\operatorname{ser}^{312}$ dotada de atividade e de significação próprias, dimensão pré-objetiva ou bruta da experiência impossível de ser reduzida aos poderes de uma consciência constituinte. No caso da pintura, cabe à ela nos mostrar uma “(...) visão que tudo sabe, que nós não fazemos, que se faz em nós." 313

Nessa tarefa, ganham ênfase na análise de Merleau-Ponty os trabalhos da pintura moderna, sobretudo por seu esforço de recusar a categoria de representação e assumir sua capacidade criadora, não buscando mais técnicas específicas para se aproximar de uma realidade dada, e sim formas de refazer e prosseguir essa realidade, encontrando suas matrizes e Ihes dando continuidade. Ocupada em "(...) multiplicar os sistemas de equivalências, em quebrar a sua aderência ao envoltório das coisas" ${ }^{\text {"14 }}$, a pintura moderna assume explicitamente a dinâmica formativa própria ao Ser. Segundo Merleau-Ponty, ela não pretende mais apenas procurar o objeto visível, mas sobretudo aquilo que o faz visível, as "essências ativas e vivas" que o configuram e manifestam, reconhecendo o Logos espontâneo operante no sensível, princípio geral de articulação do todo feito pela correlação dos termos e responsável por uma "(...) apresentação sem conceito do Ser universal” ${ }^{315}$. Isto é, responsável pela auto-configuração e pela exposição espontânea do Ser, como unidade e ecceidade. Como indicamos acima e desdobraremos

312 Em nossa leitura, e redução é para Merleau-Ponty, desde a Fenomenologia da Percepção, um procedimento ontológico, encarregado de revelar uma estrutura de ser que escape ao domínio da consciência. Conforme nossa pesquisa de Mestrado (MOURA, Alex de Campos. Liberdade e situação em Merleau-Ponty: uma perspectiva ontológica, São Paulo: Humanitas, 2010). Também na análise da linguagem, trabalhada no capítulo anterior, pudemos apontar essa questão.

313 MERLEAU-PONTY, Maurice. O Olho e o Espírito. In: Os Pensadores, São Paulo: Abril, 1975, p. 282

314 Idem, p. 295

315 Idem, p. 295 
agora, o esforço da pintura deixa de ser o de identificar-se ao real e passa a ser o de reestruturá-lo, recuperando a sua própria dinâmica. É a geração interna ao Ser que a pintura busca, não como seu objeto, mas como matriz que sua atividade prossegue: "Essa animação interna, essa irradiação do visível é que o pintor procura sob os nomes de profundidade, de espaço e de cor." ${ }^{316}$

Como afirma o filósofo, a questão da pintura moderna não é mais falar sobre o visível, mas tornar visível, criar visibilidade; ela deixa de usar seus recursos como representações de algo externo a eles, e os recupera como por si mesmos significativos. Seu trabalho passa a ser "deixar falar" a luz e a cor, isto é, reconhecê-las como dotadas de sentido próprio, forças ou dimensões capazes de criar, refazendo o movimento de gênese que descobrem no próprio Ser. Assim como a água da piscina não é um empecilho à visão do ladrilho, mas aquilo mesmo que o faz visível, que o oferece tal como ele é por si "longe de qualquer identidade"317, cabe reconhecer as "técnicas" da pintura não como distorções sobre um real dado, mas como potências estruturantes de realidade, geradoras do visível. Cabe notar - como sugerimos anteriormente e explicitaremos no próximo capítulo, principalmente por meio da análise da noção de Wesen - que isso implica uma outra noção de real: assim como o ladrilho pode se mostrar na água por ser não identidade, mas irradiação ou estilo, modulação capaz de transitar por diferentes materialidades, também o real pode se manifestar no trabalho de elaboração da pintura porque ele próprio é não idêntico, porque ele irradia e se diferencia, abertura e dissonância concretas, estruturado

\footnotetext{
316 Idem. p. 295

317 Idem, p. 294
} 
pela relação interna entre a parte e o todo assegurada pela diferença que os unifica.

Retomando nossa descrição sobre a pintura, é sob essa questão da gênese que o filósofo desenvolverá sua discussão sobre a cor, a linha e o movimento, orientando sua análise no sentido de reconhecê-los como irradiações ou instituições, movimento de configuração que desdobra o Logos já inscrito no mundo. Como veremos, assim como o Ser do qual extrai os contornos gerais de seu trabalho, a pintura opera não de modo dicotômico, sobrepondo uma forma e uma matéria autônomas ${ }^{318}$, mas por diferenciação e transformação do todo, unidade que se modifica sem romper-se. Suas técnicas significam não de modo objetivo ou direto, mas enquanto dimensões, transformação e "deformação" encarregadas de estilizar ${ }^{319}$ o Ser geral em que se manifestam. Frente a ele, elas terão um valor diacrítico, serão modulações que não negam a unidade já existente mas a transformam do interior e a confirmam enquanto processo, espécie de negatividade determinada, central, como veremos, na constituição do Ser apresentado por MerleauPonty.

Nos parece ser a partir desse viés que Merleau-Ponty interpreta o retorno de Cézanne à cor, justamente como busca do artista por uma alternativa à cisão entre forma e matéria, por um modo de significar não polarizado entre uma significação e um espaço desvinculados. Na interpretação do filósofo, Cézanne teria descoberto a cor como espacialização e formalização simultâneas, sistema único responsável por uma estrutura ao

318 Conforme também a análise da relação entre o real e o imaginário, feita acima.

319 Conforme a noção de estilo, indicada acima e trabalhada no capítulo anterior. 
mesmo tempo significativa e concreta, feita pela diferenciação de uma unidade mais ampla: "O retorno à cor tem o mérito de conduzir a um pouco mais perto do 'coração das coisas': mas ele está para além da cor-envoltório como do espaço-envoltório (...) elas [as cores] têm por função doravante facetar, recortar um ser mais geral do que o ser-amarelo ou o serverde ou o ser-azul - como, nas aquarelas destes últimos anos, o espaço (...) irradia em torno de planos que não estão em lugar algum designável, 'superposição de superfícies transparentes', 'movimento flutuante de planos de cor que se recobrem, que avançam e que recuam'."320

Modulando um Ser mais amplo, a cor cria sentido através da diferença que instaura, pela "deformação" ${ }^{321}$ que realiza em uma unidade já em curso ${ }^{322}$. Ela não opera como representação de uma significação extrínseca, seja ela empírica ou ideal, mas como gênese interna, reestruturação do todo capaz de fazer surgir um novo arranjo. Seu movimento significativo não é portanto positivo, não estabelece um sentido objetivo e determinado, realizando-se ao contrário como uma espécie de deslizamento ou de subversão, criação de diferenças e relevos que enformam a generalidade de um modo singular, reconfiguração e não posição: “(...) trata-se da dimensão da cor, daquela que por si mesma e para si mesma cria identidades, diferenças, uma contextura, uma materialidade, uma qualquer coisa...”323 De maneira equivalente, segundo a análise de Merleau-Ponty,

${ }^{320}$ MERLEAU-PONTY, Maurice. O Olho e o Espírito. In: Os Pensadores, São Paulo: Abril, 1975, p. 294

${ }^{321}$ Noção de "deformação coerente" trabalhada na Prosa do Mundo e em Signos, conforme indicado no capítulo anterior.

${ }^{322}$ Reencontrando o que já havia sido indicado na análise sobre a relação entre o imaginário e o real, trabalhada acima.

${ }^{323}$ MERLEAU-PONTY, Maurice. O Olho e o Espírito. In: Os Pensadores, São Paulo: Abril, 1975, p. 293 
opera a linha. Também ela é "descoberta" pela pintura moderna não mais como contorno ou atributo positivo do objeto, e sim como dimensão geradora de sentido, operante por metamorfose interna do todo, criação e não representação: "Trata-se só de liberá-la, de fazer reviver o seu poder constituinte (...) Porque já agora, consoante a palavra de Kee, ela não mais imita o visível, 'torna visível', é a épura de uma gênese das coisas." ${ }^{324}$

Como a cor, a linha não é cópia, mas formação do real, movimento responsável pela configuração do visível. Ela também não significa de modo positivo, sobrepondo sua forma a uma espacialidade pré-dada, mas por transformação e estilização do Ser, criação de dimensões e diferenças, maneira singular de configurar a generalidade, orientá-la e estruturá-la. Seja em Klee ou em Matisse ${ }^{325}$, seja de modo deliberado ou não, a pintura moderna recorre à linha como elemento gerador, instauração de sentido por meio da dilatação e da reconfiguração do dado. Tanto a linha quanto a cor, desse modo, nos ajudam a compreender o processo significativo indicado pelas diversas descrições de MerleauPonty, marcado pela recusa da dualidade clássica ${ }^{326}$. Mais ainda, explicitando o valor analítico da pintura, elas ajudam a compreender o sentido ontológico desse processo, revelando-o como fusão entre o Ser e o Nada, exercício de um tipo de negação determinada que não o recusa o Ser, mas ao contrário o constitui:

“[A linha] É um certo desequilíbrio disposto na indiferença do papel branco, é um certo furo praticado no em-si, um certo vazio constituinte (...) A linha não é mais, como

\footnotetext{
324 Idem, p. 295

325 Idem, p. 295

326 Conforme indicado ao longo deste capítulo e dos anteriores.
} 
em geometria clássica, o aparecimento de um ser sobre o vazio do fundo; é, como nas geometrias modernas, restrição, segregação, modulação de uma espacialidade prévia." ${ }^{327}$

Nessa passagem, breve mas central, Merleau-Ponty reafirma a dimensão ontológica implicada pela pintura e, mais geralmente, pelo processo de formação do sentido, confirmando o que vinhamos procurando indicar ao longo de nossas análises. Afastando-se da ontologia que separa o Ser e o Nada, que os compreende como entidades positivas e opositivas, fazendo da significação a expressão de um puro Nada que vem romper a indiferença do em si e manifestar sua pura capacidade formativa - como a ontologia sartreana - cabe reconhecer uma negatividade que não é diversa do Ser, que não Ihe é estranha ou externa, mas aquilo mesmo que o constitui, negação determinada que o reafirma como processo e dinâmica. Contra a ontologia que cinde o Ser e o Nada, é preciso encontrar uma compreensão unitária que mantenha a especificidade dos termos, sem o que não haveria criação ou movimento, mas que não faça deles estruturas alternativas, sem o que recairia novamente no modelo da constituição extrínseca. Reencontrando suas análises anteriores $^{328}$, o operador a que ele recorre para construir essa ontologia que não é nem da identidade e nem da alteridade, que recusa a cisão entre o ser e o nada, é a noção de diferença, capaz de sustentar um ser composto por uma negatividade interna e um nada que é constituinte do ser:

"O começo do traçado estabelece, instala um certo nível ou modo de linear,

327 Idem, p. 296

${ }^{328}$ O mesmo que aparece em seus estudos sobre a percepção, a temporalidade, a linguagem... conforme os capítulos anteriores e nossa pesquisa de Mestrado (MOURA, Alex de Campos. Liberdade e situação em Merleau-Ponty: uma perspectiva ontológica, São Paulo: Humanitas, 2010). 
uma certa maneira, para a linha, de ser e de se fazer linha, de 'continuar linha'. Com relação a ele, toda inflexão que segue terá valor diacrítico, será uma relação da linha a si, formará uma aventura, uma história, um sentido da linha, conforme ela declinar mais ou menos, mais ou menos depressa, mais ou menos sutilmente." 329

O processo de significação não é representação porque ele é intrínseco, é movimento interno por meio do qual uma unidade se auto-diferencia, cria um diálogo e um movimento em si mesma, manifestando uma negatividade estrutural, descentramento ou "deformação" que a transforma, confirmando-a enquanto unidade dinâmica. O negativo aqui é segregação, diferença e subversão. O Ser é mudança e auto-negação dirigida, devir e abertura. Não mais entidades positivas portanto, mas diferentes momentos de um mesmo processo, do movimento de auto-metamorfose próprio a um Ser tecido pelo negativo.

É por isso que não se pode mais considerar que a linha e a cor se limitem a estabelecer os limites de uma forma pré-definida, pois a gênesse do sentido é agora desdobramento dessa estrutura de Ser que desconhece a cisão entre o Ser e o Nada, entre a matéria como um puro em-si desprovido de valor e o Nada como uma pura significação translucida. A criação não é sobreposição de uma forma subjetiva sobre uma materialidade inerte, aparição do Nada sobre o Ser, mas exercício dessa negatividade estrutural ao Ser que garante a diferença e a dimensionalidade no interior do todo. Ela não é portanto negação do Ser, mas afirmação de sua abertura, de sua densidade e de seus horizontes: a negatividade aqui é distância de si, dilatação e desdobramento. Movimento no qual o Ser se

${ }^{329}$ MERLEAU-PONTY, Maurice. O Olho e o Espírito. In: Os Pensadores, São Paulo: Abril, 1975, p. 296 
descentra, cria consigo mesmo uma relação e uma aventura, o negativo é diferença que afirma indiretamente a totalidade em cada uma de suas manifestações. Cada termo, enquanto se forma como transformação da generalidade, implica e confirma essa generalidade, e a parte agora é espontaneamente expressiva do todo, negação determinada que reafirma o negado enquanto horizonte e solo $^{330}$. Sobre a questão fenomenológica central indicada anteriormente, referente à relação entre a parte e o todo, a solução merleau-pontyana vai buscar na relativização ontológica, no campo de contato entre o Ser e o Nada, uma comunicação interna e reciprocamente constitutiva entre eles, um não sendo senão uma modalização do outro, expressão e referência recíproca, diferenças que revertem e confirmam uma unidade geral:

"[O quale] como textura, ele é a concreção de uma visibilidade universal, de um único Espaço que separa e que reúne, que sustente toda coesão (e até mesmo a do passado com o futuro, visto que ela não existiria se eles não fossem partes no mesmo Espaço). Cada coisa visual, por muito que se trate de um indivíduo, funciona também como dimensão, porque se dá como resultado de uma deiscência do Ser. Quer isto finalmente dizer que é próprio do visível ter um forro de invísivel no sentido próprio, que ele torna presente como uma certa ausência." 331

\footnotetext{
330 Encontra-se aí uma característica que afasta profundamente a noção de diferença proposta por MerleauPonty daquela defendida por Derrida. Seguindo um caminho analítico diverso, mostrando como cada um deles se apropria da matriz husserliana, Dastur mostra que enquanto para Merleau-Ponty a idéia de diferença se coaduna com a de Stiftung e de instituição, permitindo o estabelecimento de dimensões duráveis para a experiência, para Derrida a idéia de diferença implica justamente a recusa de todo referencial, pura diferenciação e ausência, afastando-se das idéias de expressão e de história. (DASTUR, Françoise. Chair et langage, Paris: encre marine, 2001, p. 22-24).

331 MERLEAU-PONTY, Maurice. O Olho e o Espírito. In: Os Pensadores, São Paulo: Abril, 1975, p. 299
} 
Essa passagem, para nós central, torna explícito o sentido do negativo e sua função ontológica proposta por Merleau-Ponty. Ele é constituinte de um Ser feito por diferenciação, descentramento interno por meio do qual ele próprio se modaliza, se singulariza e manifesta, sem abrir mão de sua unidade. É esse negativo que assegura a reversibilidade estrutural e orgânica entre a parte e o todo, entre o singular e o geral, unidade ontológica que recusa os paradigmas do pensamento clássico.

Cada coisa, enquanto não se afirma senão como essa "deiscência" ou diferenciação do Ser, não é inteiramente singular, remete a mais que si mesma e se revela estruturalmente formada por horizontes de um movimento mais geral que a envolve. Como veremos, é essa negatividade estrutural do Ser que configura o "invisível", abertura interna que sustenta a ecceidade do visível - tema central de O Visível e Invisível, que retomaremos no capítulo seguinte. Não se trata pois de uma negatividade absoluta, externa ao Ser, como seria uma subjetividade constituinte, mas dessa negação determinada, responsável pela síntese espontânea e pelo Logos já operante no mundo percebido. Passagem e descentramento, dissonância que assegura uma gênese estrutural, atando a singularidade dos elementos à generalidade do sentido, esse negativo do Ser impede que haja um puro Nada e um puro Ser, pois o originário nele é a transição, metamorfose orgânica própria a uma unidade diacrítica.

Assim, se a criação, como vinha sendo indicado, não pode ser resultado de um processo de constituição, se ela não pode manter a dualidade entre sujeito e objeto, é porque o movimento de vir a ser, negar-se e confirmar-se em um sentido novo, é estrutural 
ao Ser, sua constituição mesma. Se ele, como afirma Merleau-Ponty, é o que pede de nós criação, não é por determinar os atos singulares que o manifestam, privar os homens de sua liberdade e destituí-los de seus direitos, mas por ser ele próprio gênese contínua e criação ininterrupta, matriz de todo processo de formação de sentido; quer dizer, por ser ele próprio expressão. Assim compreendida, a dinâmica expressiva se revela originária e generalizada, calcada em uma unidade ontológica que recusa tanto a identidade quanto a alternativa entre os termos, ensinando um modo de ser feito pela reversibilidade que faz de cada um deles referência e expressão de seu outro, comunicação interna que os impede de repousar em si e torna impossível distinguir completamente o que é o dado e o que é a criação $^{332}$ :

“É, pois, o próprio o Ser mudo que vem a manifestar seu próprio sentido. Eis aí porque o dilema da figuração e da não-figuração está mal posto: é a um tempo verdadeiro e sem contradição que nenhuma uva jamais foi o que ela é, na pintura mais figurativa, e que nenhuma pintura mesmo abstrata, pode eludir o Ser, ou que a uva de Caravaggio é a própria uva. Esta precessão daquilo que é sobre aquilo que se vê e se faz, daquilo que se vê e se faz sobre aquilo que é, é a própria visão. E para dar a fórmula ontológica da pintura, quase que não se devem forçar as palavras do pintor, visto que Klee escrevia aos trinta e sete anos estas palavras que Ihe foram gravadas no túmulo: 'Sou inapreensível na imanência...'." 333

${ }^{332}$ Essa idéia aparece com força desde o início da obra de Merleau-Ponty, e é, a nosso ver, um dos eixos principais de sua filosofia. Conforme procuramos mostra em nossa pesquisa de Mestrado (MOURA, Alex de Campos. Liberdade e situação em Merleau-Ponty: uma perspectiva ontológica, São Paulo: Humanitas, 2010).

333 MERLEAU-PONTY, Maurice. O Olho e o Espírito. In: Os Pensadores, São Paulo: Abril, 1975, p. 299 
Reafirmando o forte sentido ontológico da visão - e, a partir dela, da pintura $^{334}$-, ela é abertura que responde simultaneamente pela ipseidade do sujeito e pela ecceidade do mundo. Se, como vimos ao longo do capítulo, a visão e a pintura recusam a idéia de adequação e de representação, revelando-se como dinâmica instituinte que põe em suspenso os paradigmas supostos pelos pensamento clássico, é justamente enquanto manifestações dessa expressividade operante, transição espontânea entre a parte e o todo responsável pela formação de uma unidade em processo de gênese constante. Precessão simultânea do todo em relação à parte e da parte em relação ao todo, a visão é singularidade que se generaliza e generalidade que se particulariza, ensinando um modo de Ser em que o si já é abertura à ecceidade do sentido, inserção no logos espontâneo que faz dele não mais que uma modalização singular do todo. A estrutura da visão, como vimos, explicita um "para si" que se realiza não como identidade, mas justamente como diferença, negação determinada que adquire sentido justamente afastando-se de si, participando da generalidade e da unidade instável do mundo. O para si e o em si, o singular e a geral, são agora momentos desse Ser dissonante que irradia sem abandonar-se, expressão e metamorfose constante asseguradas pela estrutura intercambiável de seus termos. O ser para si é também em si, a singularidade é abertura ao geral; o ser em si é também para si, a generalidade é modalização constante. Cada um deles, portanto, referência e passagem ao seu outro, simultaneidade ao invés de alteridade: "Só ela [a visão] me ensina que seres

334 Retomando o que vínhamos indicando acima. 
diferentes, 'exteriores', estranhos um ao outro, estão todavia, absolutamente juntos - e é isso a 'simultaneidade' (...) Os trilhos que convergem e não convergem, que convergem para permanecerem lá longe equidistantes, o mundo que é segundo a minha perspectiva para ser independente de mim, que é para mim a fim de ser sem mim, a fim de ser mundo. O 'quale visual' dá-me, e só ele me dá, a presença daquilo que não sou eu, daquilo que é simples e plenamente." 335

Passagem interna e espontânea entre o para si e o em si, abertura estrutural que generaliza toda singularidade, a visão recusa a ontologia clássica e especialmente sua compreensão dualista, cindida entre sujeito e objeto. Reversível, ela assegura que a parte se vincule ao todo, que o singular se dilate em um sentido mais amplo; garante a formação espontânea de uma unidade coesa, conjunto coerente e sistemático feito pela constituição híbrida de seus elementos, não polarizado entre um puro constituinte e um puro constituído, unidade feita por diferenciação e referência interna de suas partes. Operando, assim, por abertura ou negatividade estrutural, ela se afasta tanto da identidade quanto da transcendência puras, realiza-se como passagem e transição, transformação que conserva, negação determinada que preserva o negado enquanto solo. Ela se torna, enfim - como procuramos explicitar ao longo das análises acima - paradigma da reversibilidade do Ser, expressão da imbricação entre Ser e Nada que faz da parte uma modalização do todo e do todo uma distensão da parte, negatividade estruturante que responde pela transição originária entre o si e o mundo, o singular e o geral. Unidade configurada por

${ }^{335}$ MERLEAU-PONTY, Maurice. O Olho e o Espírito. In: Os Pensadores, São Paulo: Abril, 1975, p. 299 
descentramento, a visão encarna o movimento de gênese intrínseco ao Ser, é instituição, formação espontânea do sentido por irradiação própria à sua estrutura ontológica: “(...) toda carne, e mesmo a do mundo, irradia para fora de si mesma (...) Agora talvez se sinta melhor tudo o que essa palavrinha exprime: ver. A visão não é um certo modo de pensamento ou da presença a si: é o meio que me é dado de estar ausente de mim mesmo, de assistir de dentro a fissão do Ser, só no termo da qual eu me fecho sobre mim."336

Longe do modelo da constituição e da positividade dos termos por ele implicada, o Ser merleau-pontyano é recusa da alternativa entre identidade e alteridade, articulação do sujeito e do objeto por meio da reversibilidade entre o ser e o nada. Ele não lida com entidades positivas e opositivas - tais quais as da ontologia clássica - porque ele opera por irradiação e fissão, isto é, por abertura interna de uma unidade dialógica que se constitui e reconstitui constantemente por sua negatividade estrutural. Movimento espontâneo de instituição operante por auto-diferenciação, metamorfose interna e autoregulada em que os termos se formam como modulações de uma unidade comum, atados enquanto momentos de uma mesma totalidade. A visão é "ausência de si" porque ela é abertura que insere o singular em um movimento de gênese já operante, participação nessa unidade diacrítica que se forma justamente por distanciamento de si, dilatação e generalização espontâneas. Ela confirma, enfim, como mostraram as análises anteriores, a abertura como condição originária do Ser, a instituição como matriz de toda criação, e a decorrente ecceidade do mundo e do sentido, configurando dimensões originárias que pré-

336 Idem, p. 298 
modulam os poderes do sujeito: "O olho realiza o prodígio de abrir à alma aquilo que não é alma, o bem-aventurado domínio das coisas, e seu deus, o sol”337.

A ontologia implícita pela visão e pela pintura reencontra, enfim, como apontamos no correr do texto, a mesma estrutura de Ser implicada pelas análises de Merleau-Ponty sobre a percepção, a linguagem e a temporalidade, retomando a questão fundamental em sua filosofia sobre a gênese espontânea do sentido, responsável por uma unidade que se forma por diferenciação estrutural, transição orgânica entre a parte e o todo que prescinde de um operador externo e faz da expressão uma estrutura originária da experiência. Revelando a abertura como condição constitutiva do movimento de gênese próprio a esse Ser temporal e diacrítico, suas análises apontam para uma outra relação entre o Ser e o Nada, calcada na dissolução dos termos, afirmação de uma estrutura única que faz de cada um deles uma diferenciação e uma referência do outro, reciprocamente constituintes enquanto momentos reversíveis. Elas explicitam, enfim, a insuficiência da ontologia clássica e de seu suposto dualismo entre sujeito e objeto, incapazes de dar conta da dimensão instituinte revelada na configuração ontológica proposta por Merleau-Ponty:

“A visão do pintor não é mais um olhar sobre o exterior, relação 'físico-óptica' com o mundo. O mundo não está mais adiante dele por representação: antes, o pintor é que nasce nas coisas como por concentração e vinda a si do visível; e o quadro, finalmente, não se refere ao que quer que seja entre as coisas empíricas senão sob a condição de ser

${ }^{337}$ MERLEAU-PONTY, Maurice. O Olho e o Espírito. In: Os Pensadores, São Paulo: Abril, 1975, p. 298 
primeiramente 'autofigurativo'; ele não é espetáculo de coisa alguma a não ser sendo 'espetáculo de nada', rebentando a 'pele das coisas' para mostrar como as coisas se fazem coisas e o mundo se faz mundo. Dizia Apollinaire que num poema há frases que não parecem ter sido criadas, parecem ter sido formadas. E Henri Michaux observa que algumas vezes as cores de Klee parecem lentamente nascidas na tela, emanadas de um fundo primordial, 'exaladas no justo lugar' como uma pátina ou um bolor."338

É essa estrutura reversível do Ser, responsável por assegurá-lo como gênese espontânea e instituição, que a análise do Visível e o Invisível nos ajudará a compreender, conforme trabalharemos no próximo capítulo.

338 Idem, p. 294 


\section{Entre o Ser e o Nada: o visível e o invisível}

1. Introdução

"O que nos importa é precisamente saber o sentido do ser do mundo; a esse propósito nada devemos pressupor, nem a ideia ingênua do ser em si, nem a ideia correlata de um ser de representação, de um ser para a consciência, de um ser para o homem: todas essas são noções que devemos repensar a respeito de nossa experiência do mundo, ao mesmo tempo que pensamos o ser do mundo. Cabe-nos reformular os argumentos céticos fora de todo preconceito ontológico, justamente para sabermos o que é o ser-mundo, o sercoisa, o ser imaginário e o ser consciente.”339

Prosseguindo nossos estudos anteriores, procuraremos circunscrever agora

${ }^{339}$ MERLEAU-PONTY, Maurice. O Visivel e o Invisivel, São Paulo: Perspectiva, 2007, p.18 
como base principal de nossa análise seu texto o Visível e o Invisível ${ }^{340}$. Trata-se de

mostrar, em continuidade com o que foi indicado anteriormente, que suas descrições

opõem-se à ontologia clássica, sobretudo à cisão entre o ser em si e o ser para si,

buscando explicitar uma estrutura ontológica unitária, feita pela imbricação ou pela

reversibilidade entre o Ser e o Nada.

${ }^{340}$ Diferentemente do que ocorre em outros momentos da obra de Merleau-Ponty, quando se tratam de análises sobre $O$ Visivel e o Invisível, a questão da ontologia ocupa um lugar central na maior parte dos comentários. De modo geral, parece haver duas linhas principais de interpretação, especialmente no que se refere à posição dessa ontologia no interior de sua reflexão: uma que privilegiaria sua continuidade com as proposições iniciais, especialmente com a Fenomenologia da Percepção, e outra que acentuaria as rupturas que o projeto de $O$ Visivel e o Invisivel trariam. Uma vez mais, a questão principal de divergência parece recair sobre a compreensão das primeiras obras do autor, e consequentemente sobre o lugar da ontologia descrita em seus últimos textos. A esse respeito, ver Ferraz, que aponta a distância entre essas duas linhas principais de leitura: FERRAZ, Marcus Sacrini. Fenomenologia e ontologia em Merleau-Ponty, SP: Papirus, 2009.

Embora não se possa reduzir as diversas análises do filósofo, e nem atar sua diversidade a um único ponto, julgamos, apenas como indicação, que é possível reconhecer um certo predomínio da vertente que privilegia a ruptura. Isso porque, segundo a maioria das análises, a Fenomenologia da Percepção não teria sido capaz de efetivamente escapar do dualismo ontológico clássico. O principal autor nessa linha é Barbaras, segundo o qual haveria mesmo uma falta de embasamento propriamente filosófico para as descrições dessa obra (BARBARAS. De l'être du phénomène): embora a análise da percepção tenha descortinado um campo novo, o filósofo ali permanece incapaz de efetivamente problematizá-lo, preso aos paradigmas dualistas e ao subjetivismo. Cabe notar que essa leitura é posteriormente relativizada pelo próprio autor em um texto posterior (BARBARAS, Le tournant de la experience).

Já autores como Dastur, sem entrar tanto na discussão sobre a presença ou não de uma ontologia na fase incial de Merleau-Ponty, apontam para uma certa "virada" no decorrer de sua obra, no caso dela, apontando para um afastamento em relação a Husserl e uma maior aproximação com o pensamento de Heidegger (DASTUR, chair et langage. Paris: encre marine, 2002, p.10).

Outros autores reconhecem uma certa dimensão ontológica na Fenomenologia da Percepção, mas continuam a afirmar sua insuficiência para efetivamente divergir da ontologia clássica. Como indicamos no início do trabalho, Bimbenet, por exemplo, considera que há a permanência de uma certa "atividade categorial" que se manteria desvinculada do mundo (BIMBENET, Étienne. Nature et humanité, Paris: Vrin, 2004), e Saint-Aubert julga que a noção de intencionalidade seria incapaz de efetivamente articular as descrições do filósofo (SAINT-AUBERT, Emmanuel. Le scénario cartésien, França;Vrin, 2005, p. 141).

Conforme indicado em nossa pesquisa de Mestrado (MOURA, Alex de Campos. Liberdade e situação em Merleau-Ponty: uma perspectiva ontológica, São Paulo: Humanitas, 2010) e como estamos procurando sustentar no decorrer de nossa Tese, nos aproximamos mais da leitura que reconhece uma maior continuidade e uma menor ruptura ao longo da obra do autor. 
Retomando uma perspectiva já apontada em O Olho e o Espírito ${ }^{341}$, O visível e o invisível assume como uma de suas questões principais a evidência do mundo, a necessidade de explicitar um "há" originário que não é nem posto pelo sujeito e nem oposto a ele, estrutura de Ser que recusa simultaneamente a perspectiva intelectualista e as filosofias do negativo, ensinando como veremos uma unidade espontânea que se faz por irradiação, pela presença de uma negatividade operante que descentra e unifica em um mesmo movimento, estabelecendo-se como mediação entre o ser e o não-ser puros.

A análise de Merleau-Ponty parte da constatação de que: "Vemos as coisas mesmas, o mundo é aquilo que vemos” ${ }^{342}$. Retomando uma discussão clássica ao longo da reflexão filosófica ${ }^{343}$ - se a visão se faz em mim ou no visível, se ela é ato ou passividade -, a filosofia merleau-pontyna busca compreender a sincronicidade duas dimensões, isto é, busca reconhecer uma espécie de equivalência entre o "entrar" e o "sair" de si, tomando a visão como paradigma da reversibilidade de um em outro: cabe reconhecer, segundo ele, que é justamente sua singularidade que a torna abertura à ecceidade do mundo ${ }^{344}$. Eu vejo,

341 Conforme trabalhado no capítulo anterior.

342 MERLEAU-PONTY, Maurice. O Visivel e o Invisível, São Paulo: Perspectiva, 2007, p.15

343 A esse respeito ver: CHAUÍ, Marilena de Souza. Janela da alma, Espelho do mundo. In: O olhar, São Paulo: Companhia das Letras, 1999. Neste texto, a autora faz uma grande análise sobre o sentido que a visão adquire ao longo do pensamento filosófico, explicitando essa espécie de reversibilidade que lhe é intrínseca: "Porque cremos que a visão se faz em nós pelo fora e, simultaneamente, se faz de nós para fora, olhar é, ao mesmo tempo, sair de si e trazer o mundo para dentro de si. Porque estamos certos que a visão depende de nós e se origina em nossos olhos, expondo nosso interior ao exterior, falamos em janelas da alma (...) Porém, porque estamos igualmente certos de que a visão se origina lá nas coisas, delas depende, nascendo no 'teatro do mundo', as janelas da alma são também espelhos do mundo (...)” (p. 33, 34)

344 Como indicamos nos capítulos anteriores, referindo-nos principalmente ao texto de MOURA (MOURA, Carlos Alberto Ribeiro de. Racionalidade e crise. São Paulo: Discurso Editorial / Edufpr, 2001, especialmente seu ensaio Exame de paternidade), a relação entre a parte e o todo, entre o noema e a noese, é uma questão central para Husserl, fundamental no próprio estabelecimento do campo de investigação próprio à fenomenologia.

Em nossa leitura, como estamos buscando explicitar ao longo da Tese, essa é uma das questões centrais da 
de meu ponto de vista, o sensível tal como ele é, não havendo a necessidade de se optar entre a singularidade do ato e a generalidade do mundo, mas apenas de reconhecê-los como momentos reversíveis, atados em uma unidade que não pode deixar intactas as noções clássicas de sujeito e de objeto, especialmente enquanto entidades opostas e incomunicáveis. Aquém da alternativa entre um ser em si e a vida interior, a visão remete ao seu ponto de intersecção, explicita uma mediação entre o em si e o para si, exigindo o reconhecimento da simultaneidade e da reciprocidade (comumente ignoradas pelo pensamento clássico) que fazem do singular abertura ao geral, do "para-si" passagem ao "em-si", e vice-versa.

A questão, assim, é compreender o modo pelo qual a visão - como já ensinava O Olho e o Espírito - vai às próprias coisas justamente por preservar sua singularidade, afirmação dessa reflexividade primária que torna impossível estabelecer um limite preciso entre o agente e o passivo. Acentuando o que seu ensaio havia mostrado, $O$ Visível e o Invisível, até o ponto em que é conhecido, parece ter como projeto o aprofundamento das descrições sobre essa reversibilidade, mostrando a impossibilidade de

filosofia de Merleau-Ponty, presente ao longo de toda sua obra, desde a Estrutura do Comportamento. Ela indicaria, a nosso ver, ao mesmo tempo uma proximidade e uma distância em relação a Husserl: conforme nossa pesquisa de Mestrado (MOURA, Alex de Campos. Liberdade e situação em Merleau-Ponty: uma perspectiva ontológica, São Paulo: Humanitas, 2010), se ela é reafirmação do método fenomenológico, ela é simultaneamente um dos eixos pelo qual Merleau-Ponty opera a passagem da fenomenologia à ontologia (mostrando os limites da redução e a decorrente impossibilidade de separar o singular e o geral, o fato e o sentido, reconhecimento daquilo que resiste ao campo estritamente fenomenológico, como indicado no Prefácio da Fenomenologia da Percepção), afirmando a impossibilidade da cisão entre o transcendental e o empírico, explicitando uma unidade espontânea formada pela estrutura diacrônica de seus elementos.

No que concerne o capítulo atual, a relação entre o todo e as partes, o singular e o geral, será indicada no decorrer de todo texto, respeitando o modo como é apresentada pelo filósofo em $O$ Visível e o Invisível, sendo retomada de modo mais detido no final. 
se manter o dualismo entre o ser e o não-ser puros. Como veremos, a obra inacabada toma como tema a intercambialidade entre homem e mundo, a afirmação da ecceidade do mundo e as consequências ontológicas que a análise da visão acarreta ${ }^{345}$, reencontrando a reversibilidade e a abertura como dimensões centrais do Ser.

Ainda como introdução, é importante ressaltar, como se poderá notar nas descrições seguintes, o caráter aberto da maioria das proposições feitas pelo filósofo em $O$ Visível e o Invisível, algumas aparecendo de forma introdutória, diluídas em momentos analíticos diferentes e não inteiramente circunscritos. Nossas análises, respeitando o movimento próprio ao texto, procurarão acompanhar essa circularidade, em alguns momentos retomando temas já indicados, revendo-os dentro das diversas conjunturas em que são apresentados. Isso se deve, como é apontado no próprio posfácio do livro ${ }^{346}$, ao fato de se tratar de uma obra inacabada, interrompida pela morte do autor, e por isso mesmo construída na forma de esboço e de projeto, o que não pode de forma alguma ser desconsiderado pelo trabalho analítico.

Retomando o que indicamos acima, o ponto de partida de O Visível e o Invisível é, pois, esta evidência do mundo testemunhada pela visão e já circunscrita pelo

${ }^{345}$ Como indicado no capítulo anterior, e confirmando o forte diálogo de Merleau-Ponty com Descartes, as implicações ontológicas da visão já são indicadas por ele a partir de sua análise da Dióptrica feita em $O$ olho e o espirito. Voltaremos à essa questão em uma nota mais adiante.

${ }^{346}$ Posfácio escrito por Claude Lefort, IN: MERLEAU-PONTY, Maurice. O Visivel e o Invisivel, São Paulo: Perspectiva, 2007 
ensaio de 60 , não como retorno a uma forma qualquer de empirismo, mas como reconhecimento da "abertura" originária existente entre aquele que vê e o visível, transcendência do homem e espontaneidade do percebido, configurando aquilo que Merleau-Ponty denomina "fé perceptiva" 347 . Nossa convicção na existência do mundo, mostra ele, não recorre à alguma entidade objetiva posta pela consciência, mas à impossibilidade do repouso em si, espécie de lacuna ou de negatividade que descentra o "sujeito" e o "objeto", fazendo com que eles se auto-diferenciem, extrapolem e irradiem "umno-outro" ${ }^{\text {348 }}$, revertendo-se continuamente. O que significa que não vemos o visível porque ele age sobre nós (e o ecoamos como seu efeito ${ }^{349}$ ), ou porque nós agimos sobre ele (e ele é que nos $\mathrm{eco}^{350}$ ), mas porque há uma relação originária entre a percepção e o percebido que antecede toda deliberação de uma consciência tética ${ }^{351}$. Ao falar em "fé", é precisamente esse caráter de saber espontâneo e pré-posicional que Merleau-Ponty busca preservar, mostrando que a presença perceptiva do mundo se coloca aquém da possibilidade da afirmação e da negação explícitas: “(...) [a fé perceptiva] é mais velha que

347 Assim, O Visivel e o Invisivel inicia com a afirmação: "Vemos as coisas mesmas, o mundo é aquilo que vemos - fórmulas desse gênero exprimem uma fé comum ao homem natural e ao filósofo desde que abre os olhos, remetem para uma camada profunda de 'opiniões' mudas, implícitas em nossa vida. Mas essa fé tem isso de estranho: se procurarmos articulá-la numa tese ou num enunciado, se perguntarmos o que é este nós, o que é este ver e o que é esta coisa ou este mundo, penetramos num labirinto de dificuldades e contradições." (MERLEAU-PONTY, Maurice. O Visível e o Invisível, São Paulo: Perspectiva, 2007, p. 15)

348 Respeitando a sequência do texto de Merleau-Ponty, essa questão será explicitada ao longo de todo o capítulo, tornando-se mais clara sobretudo quando tratarmos da apropriação que o filósofo faz da noção de Wesen.

349 Como supõe o objetivismo.

350 Como supõe o subjetivismo.

351 “[Fé como] adesão que se sabe além das provas, não necessária, tecida de incredulidade, a cada instante ameaçada pela não-fé. A crença e a incredulidade estão aqui tão estreitamente ligadas que uma se encontra sempre na outra e, em particular, um germe de não-verdade na verdade (MERLEAU-PONTY, Maurice. $O$ Visível e o Invisível, São Paulo: Perspectiva, 2007, p. 37).” 
qualquer opinião, é a experiência de habitar o mundo por meio de nosso corpo, a verdade nós mesmos inteiramente sem que seja necessário escolher nem mesmo distinguir entre a segurança de ver e a de ver o verdadeiro, pois que são por princípio uma mesma coisa portanto fé, e não saber, porquanto o mundo aqui não está separado do domínio que temos sobre ele, sendo, ao invés de afirmado, tomado como evidente, e ao invés de revelado, não dissimulado, não refutado." ${ }^{352}$

É essa fé primordial, essa abertura irrecusável ao mundo - abertura que não exclui, e mesmo, como veremos, exige sua possível ocultação - que a Filosofia deve compreender, respondendo como as duas possibilidades, a presença e a ausência, podem se manter lado a lado sem se anularem, como o ser e o não-ser podem se reverter e se articular, configurando uma unidade significativa e irredutível fora de todos os paradigmas clássicos. Distante do modelo da constituição e do saber como evidência "clara e distinta"353, a fé perceptiva se depara com uma presença que "se faz" por "des-presentação", evidência que comporta sua possibilidade de ocultação e, veremos, depende dela para se constituir,

${ }^{352}$ MERLEAU-PONTY, Maurice. O Visivel e o Invisivel, São Paulo: Perspectiva, 2007, p. 38

${ }^{353}$ Conforme o modelo cartesiano de conhecimento, proposto por exemplo nas Meditações ((DESCARTES, R. Meditações. In: Os Pensadores, São Paulo: Abril, 1975). O diálogo de Merleau-Ponty com Descartes, embora nem sempre considerado por seus estudiosos, é central. Apenas como um exemplo disso, podemos citar o fato, trabalhado no capítulo anterior, de Merleau-Ponty apresentar sua ontologia em $O$ Olho e $o$ Espirito justamente a partir de uma minuciosa análise sobre a Dióptrica, buscando mostrar uma espécie de "impensado" nas proposições de Descartes, o modo como se articulam ali a teoria do conhecimento e a visão, e de como a própria recusa cartesiana em tomar efetivamente a pintura como questão é já significativa de um reconhecimento tácito de seu valor ontológico e subversivo.

Como indicamos no capítulo anterior, sobre a relação entre os dois autores, ver: MOURA, Carlos Alberto Ribeiro de. Racionalidade e crise, São Paulo: Discurso Editorial / Edufpr, 2001, que mostra o forte diálogo das formulações de Merleau-Ponty com as proposições cartesianas; e também SAINT-AUBERT, Emmanuel. Le scénario cartésien, Paris: Vrin, 2005, que trata da influência e do esforço de Merleau-Ponty em se afastar do "cenário cartesiano" de sua época. 
revelando um modo de ser que não recusa o negativo, mas o envolve estruturalmente.

Para explicitar essa unidade ontológica, Merleau-Ponty - em um procedimento recorrente ao longo de sua obra ${ }^{354}$ - inicia mostrando a insuficiência das soluções subjetivistas e negativistas, explicitando a intercambialidade primária do visível e do vidente. Divergindo da ontologia dualista, a visão conduz a uma dimensão comum em que desaparece a discordância entre o em-si e o para-si, sem redução e sem exclusão. Como veremos, a perspectiva intelectualista realiza uma espécie de "conversão reflexionante", transforma a percepção em pensamento de ver, o percebido em ideia, fazendo do real não mais que um cogitata dominado de ponta à ponta pelo sujeito. As antinomias se resolvem, aqui, pela passagem à idealidade ${ }^{355}$, afirmação de um Ser puro desdobrado pela subjetividade; recusa-se a evidência do mundo como realidade efetiva, transforma-a em correspondência ou adequação a um pensamento, posta no plano da identidade e da imanência à consciência.

Correlativamente, embora por um caminho diverso, o pensamento do negativo $^{356}$, ao partir do puro Nada, também chega à compreensão do Ser como absoluta

354 Como sugerimos anteriormente, as análises de Merleau-Ponty sempre partem do campo que pretende recusar, buscam mostrar suas contradições internas e assim se afastam de uma leitura externa ou dogmática. Como indicamos, procurando encontrar uma perspectiva realmente crítica, as análises de Merleau-Ponty penetram no discurso adversário, percorrem seus próprios encaminhamentos, e fazem com que ele mesmo exponha suas insuficiências, conduzindo para além de si. Sobre a crítica como discurso interno ao seu "objeto", ver por exemplo CHAUI, Marilena de Souza. Cultura e democracia: O discurso competente e outras falas, São Paulo: ed. Moderna, 1980

355 MERLEAU-PONTY, Maurice. O Visivel e o Invisível, São Paulo: Perspectiva, 2007, p. 39

356 Termo usado pelo próprio autor para designar as filosofias que afirmam uma espécie de negatividade absoluta. Uma vez mais, como o longo comentário crítico sobre o Ser e o Nada confirma, o interlocutor principal de Merleau-Ponty é Sartre e o dualismo convicto de sua ontologia. 
positividade, opõe um ao outro e recusa por princípio qualquer forma de relação entre eles $^{357}$. Nos dois casos, seja por cisão ou por apropriação, chega-se a um resultado comum: a recusa de toda relação efetiva entre o Ser e o Nada, permanência do dualismo ontológico que obstrui qualquer forma de abertura:

“(...) uma vez mais, não obstante agora por razões opostas, torna impossível essa abertura ao ser que é a fé perceptiva. A filosofia reflexionante não a explicava, por deixar de conservar uma distância entre a ideia e a ideia da ideia, entre o reflexionante e o irrefletido. É ainda essa distância que falta agora, pois quem pensa, não sendo nada, não pode ser separado por nada de quem percebia ingenuamente, nem este do que ele percebia. Não há abertura para o ser numa filosofia do pensamento e de nossos pensamentos imanentes - nem tampouco numa filosofia do nada e do ser, pois, tanto num caso quanto no outro, o ser não é, de fato, longínquo, à distância (...) "358

Ao contrário, apoiada na compreensão de um Nada estruturante, intrínseco ao Ser, a "fé perceptiva" afirma uma dimensão anterior à exterioridade dos termos, recusa a consciência como tética e o percebido como constructo, alojando-se “(...) no sentido daquilo que existe antes de qualquer posição" ${ }^{359}$, que enforma originariamente nossa experiência e não depende de nenhum ato voluntário para se configurar, afirmando a simultaneidade entre o em-si e o para-si. A evidência do percebido implica, como veremos, não uma subjetividade absoluta, mas a abertura de um sujeito que é capaz de acolhê-lo em sua

\footnotetext{
357 Explicitaremos esse movimento do pensamento negativo mais adiante.

358 Idem, p. 90

359 Idem, p. 15
} 
espessura estrutural, transcendência recíproca entre aquele que percebe e aquilo que é percebido, negatividade inscrita em um Ser que não pode mais ser reduzido nem à condição de sujeito e nem à condição de objeto. De modo que, uma vez mais - confirmando a perspectiva analítica que nossos estudos vêm procurando indicar, nossa Tese de uma linha constante ao longo da obra de Merleau-Ponty ${ }^{360}$-, o recurso do filósofo à percepção envolve uma dimensão ontológica, oferecendo-se como alternativa à ontologia clássica: "Nosso objetivo [é] (...) mostrar que o ser-objeto e também o ser-sujeito, este concebido em oposição àquele e relativamente a ele, não constituem uma alternativa, que o mundo percebido está aquém ou além da antinomia (...) como apelo à revisão de nossa ontologia, ao reexame das noções de 'sujeito' e 'objeto'. As mesmas razões que impedem de tratar a percepção como um objeto, também impedem de tratá-la como operação de um 'sujeito', seja qual for o sentido em que possa ser tomada." 361

Retomando uma crítica constante no interior de sua obra ${ }^{362}$, o estudo da percepção deve explicitar a impossibilidade da ontologia que estabelece o Grande Sujeito e o Grande Objeto, especialmente em sua suposição de um mundo inteiramente determinado construído por atos subjetivos ${ }^{363}$, Ser plano, positivo, sem qualquer profundidade ou

${ }^{360}$ Essa questão será retomada na conclusão de seu trabalho.

361 MERLEAU-PONTY, Maurice. O Visível e o Invisível, São Paulo: Perspectiva, 2007, p. 36

${ }^{362}$ Esse é um dos temas centrais e constantes da filosofia de Merleau-Ponty. Sua crítica ao "pequeno racionalismo" e à ontologia cientificista está presente desde a Estrutura do Comportamento e percorre toda a sua obra, estabelecendo um das questões principais que sua reflexão busca ultrapassar: a configuração das noções de sujeito e objeto, especialmente em seu caráter dicotômico. A esse respeito, ver por exemplo: MOUTINHO, Luiz Damon. Razão e experiência: Ensaio sobre Merleau-Ponty, Rio de Janeiro: UNESP, 2006.

363 Segundo Merleau-Ponty, tanto a física quanto a psicologia supõem uma mesma estrutura ontológica, o dualismo clássico do subjetivo e do objetivo, definindo o objeto por relações funcionais observáveis universalmente: “A clivagem do 'subjetivo' e do 'objetivo', pela qual a Física em seus inícios define o seu 
latência, translucidez completa. Recusando essa suposta objetividade, o Ser percebido, como veremos, se caracteriza pela "ambivalência", é lacunar ou poroso, estruturado por horizontes e por uma invisibilidade que o fazem escapar ao olhar, provendo-o da espessura que lhe garante ecceidade: “(...) o próximo, o longínquo, o horizonte em seus indescritíveis contrastes formam um sistema, e suas relações no campo total é que constituem a verdade perceptiva" $^{\text {364 }}$. Como explicitará Merleau-Ponty, o mundo percebido recusa o pensamento objetivo, estruturando-se segundo leis de campo e de organização intrínsecas, gravitando em torno de uma abertura que o impede de repousar em si, que lhe recusa toda forma de identidade e imanência, transcendência por horizontes que o afasta tanto do modelo objetivista quanto do subjetivista:

“(..) a imanência psicológica ou transcendental não pode, melhor do que o pensamento 'objetivo', dar conta do que é um horizonte ou o 'longe'; a percepção que se dê a si mesma , como 'introspecção' ou consciência constituinte do percebido, deveria ser, por posição e por princípio, conhecimento e posse de si mesma - não poderia abrir-se sobre horizontes ou lonjuras, isto é, sobre um mundo que, desde o início, está aí para ela e

domínio, e a psicologia, correlativamente, o seu, não impede mas, ao contrário, exige que eles sejam concebidos segundo a mesma estrutura fundamental: são, finalmente, duas ordens de objetos, a serem conhecidos em suas propriedades intrínsecas por um pensamento puro que determina o que são em si”. Ambas, porém, como mostra o filósofo, supõem e se apóiam na fé perceptiva. Razão pela qual, embora mantenham-se presas aos paradigmas do pensamento clássico, trazem em seus resultados um apelo constante à sua revisão. A física, por exemplo, acaba por reconhecer como seres físicos últimos e de pleno direito as relações entre o observador e o observado, incluindo o contato entre eles na definição do real. Inviabiliza assim que se considere o ser como ser-objeto e que se faça das vivências apenas curiosidades psicológicas, que se tome o ser não como "aquilo para que temos abertura", mas como aquilo sobre o qual podemos operar. A psicologia, por sua vez, recorrendo a noções como comportamento e estrutura, aponta para um Ser do psiquismo definido por "estruturações heterogêneas e descontínuas que aí se realizam”, longe portanto do positivismo e da completa determinidade do objeto.

364 MERLEAU-PONTY, Maurice. O Visível e o Invisível, São Paulo: Perspectiva, 2007, p. 32 
unicamente a partir do qual ela se abre como titular anônima em cuja direção caminham as perspectivas da paisagem.."365

Abertura ou negatividade inscrita no Ser, a percepção recusa a positividade da ontologia clássica e seu pressuposto dualista; opera, como explicitaremos ao longo do capítulo, como essa simultaneidade entre o ser para si e a o ser em si, possível graças à existência de um Nada intrínseco ao Ser, implicação recíproca em uma unidade feita por afastamento e distância, configurando tanto a ecceidade do sensível quanto a reflexividade do homem. O negativo no Ser, como veremos, responderá por um para-si que é no mundo, dotado de uma dimensão de ser que é exatamente o que o permite voltar-se sobre si, em uma espécie de narcisismo sensível ${ }^{366}$; e por um em-si reflexivo, estruturado por horizontes que são justamente o que o configuram de modo próprio e irredutível. Será a negatividade no Ser que impedirá a manutenção das categorias clássicas, o dualismo do sujeito e do objeto tomados segundo a alternativa do ser e não-ser puros: "O sujeito perceptivo, como Ser-para tácito, silencioso, que retorna da própria coisa cegamente identificada, que é somente distanciamento em relação a ela - si da percepção como 'ninguém' no sentido de

365 Idem, p. 33

366 Como já antecipava $O$ Olho e o Espírito, trata-se de uma reconfiguração do Cogito inscrevendo-o na própria estrutura aberta e reflexiva do sensível, explicitando sua distância do modelo cartesiano e intelectualista. Como indicamos em nossa pesquisa de Mestrado (MOURA, Alex de Campos. Liberdade e situação em Merleau-Ponty: uma perspectiva ontológica, São Paulo: Humanitas, 2010) o modo como Merleau-Ponty compreende o Cogito é um dos pontos principais nas discussões dos comentadores a respeito do "subjetivismo" de suas obras iniciais, como por exemplo Barbaras (BARBARAS, Renaud. De l'être du phénomène. Sur l'ontologie de Merleau-Ponty, Granoble: Millon, 1991) que vê no Cogito tácito o ponto extremo do modelo subjetivista que ele reconhece na Fenomenologia da Percepção. E, de certo modo, também Lefort (LEFORT, Claude. Sur une colonne absente, Paris: Gallimard, 1978) que reconhece no Cogito tácito a manutenção de um certo intelectualismo, expresso na tentativa de formular a identidade entre o ser e o pensamento. 
Ulisses, como o anônimo oculto no mundo e que ainda não deixou seu rastro. Percepção como impercepção, evidência da não posse (...) Anonimato e generalidade. Isso quer dizer: não um nichtiges Nichts mas um 'lago de não ser', certo nada atolado numa abertura local e temporal." ${ }^{367}$

Seguindo nossa hipótese de trabalho, será esse caráter difuso da percepção - aproximação como distância, presença como ocultação -, e a ontologia nela implícita, baseada na relação intrínseca entre o Ser e o Nada, que procuraremos explicitar. Vejamos, pois, como Merleau-Ponty circunscreve a questão recusando as duas vertentes correlatas e igualmente dualistas: as filosofias do negativo e as intelectualistas.

${ }^{367}$ MERLEAU-PONTY, Maurice. O Visivel e o Invisível, São Paulo: Perspectiva, 2007, p. 190 


\section{A crítica às filosofias do negativo}

Como apontado acima, um dos caminhos pelo qual Merleau-Ponty começa a explicitar esse sentido do Nada é mostrando a insuficiência das filosofias do negativo, e as contradições a que chegam ao opô-lo frontalmente ao Ser. Sua crítica busca mostrar que o ponto de partida da Filosofia, a dimensão originária que se deve trazer à luz, não é a do Ser ou do Nada, mas precisamente a mediação entre eles, aquilo que o filósofo denominará o "há" do mundo ${ }^{368}:$ unidade ontológica de um Ser configurado pelo negativo. O originário, como veremos, não será mais a alternativa, mas a abertura e a reversibilidade de um em outro testemunhada pela fé perceptiva.

No Visível e Invisível, Merleau-Ponty empreende uma longa crítica às filosofias da negatividade, em especial àquela defendida por Sartre em O Ser e o Nada ${ }^{369}$.

368 Procuraremos mostrar ao longo do capítulo que o "há" originário de que fala Merleau-Ponty é justamente a expressão dessa unidade ontológica do Ser e do Nada, feito pela simultaneidade e pela constituição recíproca de um pelo outro.

369 Como indicamos nos capítulos anteriores, a discussão com Sartre é uma constante ao longo de toda a obra de Merleau-Ponty. Presente na Fenomenologia da Percepção, em Sense et Non-Sense, e em praticamente todos os seus textos, ela indica, a nosso ver, ao mesmo tempo uma proximidade (temática) e uma distância (quanto à resposta). Conforme procuramos indicar em nossa pesquisa de Mestrado (MOURA, Alex de Campos. Liberdade e situação em Merleau-Ponty: uma perspectiva ontológica, São Paulo: Humanitas, 2010) e em nosso texto Sobre a questão do sentido em Merleau-Ponty: introdução a partir de uma relação com Sartre 
Ele mostra que, por partirem do Nada, elas acabam por repor, a despeito de seus propósitos explícitos, uma cisão entre o para si e o em si que lhes recusa qualquer relação efetiva. O pensamento do negativo toma o Ser como absoluta positividade ${ }^{370}$, exclui dele qualquer negação, chegando a uma entidade extensa, plana e uniforme. Recai, assim, em uma filosofia da identidade, retorna, pelo caminho inverso, a uma forma de positivismo que se mantém no interior da ontologia clássica: Enquanto negatividade pura, o Nada é fundante e não há o que o separe das próprias coisas, nenhuma espessura ou distância dele ao Ser; como não ser absoluto, ele será nega-intuição que desemboca no advento de um Ser puro, idêntico a si e absolutamente outro: "O chamamento do Ser ao nada é, na verdade, chamamento do nada ao Ser, auto-negação. O nada e o ser são sempre absolutamente outros, é precisamente seu isolamento que os une (...) O pensamento do negativo puro ou do positivo puro é, pois, um pensamento de sobrevôo, que opera com a essência ou com a pura negação da essência, com termos cuja significação já foi fixada e que mantém em sua posse."371

Concebidos desse modo, de um a outro não há passagem, nenhuma reversibilidade possível. Ao partir da completa exterioridade, as filosofias do negativo julgam os poderes da vida pelos da morte, definem a primeira simplesmente como o conjunto de forças que resiste à segunda, fazendo da definição do Ser a supressão do não-ser ${ }^{372}$. "Pensamento do imediato", elas afirmam tudo, o não-ser e o há, o sujeito e o mundo, mas (MOURA, Alex de Campos. IN: GENTIL, Hélio; CARNEIRO, Marcelo. Filosofia Francesa Contemporânea, São Paulo: Cultura Acadêmica Editora, 2009).

${ }^{370}$ MERLEAU-PONTY, Maurice. O Visivel e o Invisivel, São Paulo: Perspectiva, 2007, p. 70

${ }^{371}$ Idem, p. 74

${ }^{372}$ Idem, p. 89 
apenas para mantê-los absolutos em sua identidade: “(...) justamente porque o nichtiges Nichts não é, o há reserva-se a um ser sem mistura, positivo, pleno, justamente porque não há a ideia do nada, o nada nadifica livremente, enquanto o ser é."373

Assim, ao proporem uma espécie de "coesão maciça" entre o Ser e o Nada, essas filosofias os separam inteiramente: não há articulação interna porque eles se mantêm juntos em permanente contradição ${ }^{374}$, cada um fechado sobre si. Concebidos como pura negatividade e pura positividade, ambos se tornam instâncias incomunicáveis, desprovidas precisamente da abertura sem a qual toda relação se torna uma abstração ${ }^{375}$ :"Um pensamento negativista é do mesmo modo um pensamento positivista, e nessa reviravolta permanece o mesmo, no seu propósito de, considerando o vazio do nada ou o pleno absoluto do ser, ignorar em todo caso a espessura, a profundidade, a pluralidade de planos, os segundos-mundos (arrière-mondes)."

Desse modo, conclui Merleau-Ponty ${ }^{377}$, ou a filosofia do negativo permanece fiel a seus pressupostos, e a relação efetiva do sujeito com o mundo e com os outros se torna uma impossibilidade de princípio, ou é preciso que ela ultrapasse suas próprias premissas, e reconheça uma porosidade no Ser e uma consistência do Nada, capazes de sustentar a reversibilidade de "um-no-outro". Como indica o filósofo, na relação com o

\footnotetext{
${ }^{373}$ Idem, p. 89

${ }^{374}$ Idem, p. 74

375 Idem, p.74, 86

376 Idem, p. 73

377 Idem, p. 94
} 
sensível e com os outros ${ }^{378}$, não há um Nada universal diante de um Ser puro, não há uma visão encarregada de "nadificar" aquilo que Ihe aparece, e assim preservar a antinomia dos termos $^{379}$. Como atesta a fé perceptiva, uma relação efetiva, em que os termos se relacionam sem se anularem, implica a existência de uma abertura estrutural entre eles, nem a identidade (que destrói a diferença) e nem a alteridade (que destrói a comunicação), mas a passagem espontânea e constitutiva de um ao outro: é preciso que haja entre o "agente" e o "percebido" uma relação carnal ${ }^{380}$, imbricação por transcendência, graças à negatividade por eles partilhada, em uma “(...) distância que não é nada, que não é desdobrada por mim, que é alguma coisa que, portanto, Ihe pertence, que é entre o ser 'puro' e mim, a espessura de seu ser para mim, de seu ser para os outros (...)"381. Negativo, portanto, que é abertura que possibilita a relação, ser-para simultaneamente reflexivo, parasi, e diferido ${ }^{382}$, para-outrem. Simultaneidade do ativo e do passivo, do sujeito e do objeto, a estrutura perceptiva implica o reconhecimento dessa negatividade no Ser, capaz de

${ }^{378}$ Como indicamos anteriormente, a questão da intersubjetividade é longamente trabalhada por Bonan, que trata de sua presença no decorrer de toda a obra de Merleau-Ponty, desde seu início até suas últimas formulações. Ele mostra que a noção de "carne", em seu caráter fundamentalmente aberto, implica necessariamente a intersubjetividade: "Dans ses aspects statiques comme dans ses aspects dynamiques, la chair implique, préssuppose, exige et épouse les formes de la dimension commune intersubjective." (BONAN, Ronald. L'institution intersubjective comme poétique générale v. 1, L’Harmattan, 2001, p. 346)

379 "Longe de abrir-se para a luz ofuscante do Ser puro ou do Objeto, nossa vida possui no sentido astronômico da palavra, uma atmosfera; está constantemente envolvida por essas brumas que chamamos mundo sensível ou história, o sujeito indeterminado (on) da vida corporal e o sujeito indeterminado da vida humana, o presente e o passado, como conjunto misturado de corpos e espíritos, promiscuidade de rostos, palavras, ações, e com essa coesão entre todos, que não podemos recusar-lhes já que todos são diferenças, distâncias extremas de um mesmo algo." (MERLEAU-PONTY, Maurice. O Visível e o Invisível, São Paulo: Perspectiva, 2007, p. 87).

380 A noção de carne será explicitada mais adiante.

381 MERLEAU-PONTY, Maurice. O Visivel e o Invisivel, São Paulo: Perspectiva, 2007, p. 86

382 Explicitaremos ao longo do texto essa simultaneidade entre a dimensão reflexiva do Ser e sua ecceidade, mostrando uma espessura que $e$ abertura e vice-versa, ser e não-ser reversíveis e distantes de qualquer positivismo clássico. 
assegurar a passagem intrínseca entre o singular e o geral, espessura e distância que configuram tanto sua ecceidade quanto sua reflexividade, unidade e transcendência reciprocamente constitutivas. Como veremos, recorrendo às noções de carne e de irradiação do sensível ${ }^{383}$, a questão para Merleau-Ponty será justamente explicitar essa unidade ontológica, mostrando que o primeiro não é o Ser ou o Nada, mas a "invasão" de um no outro, constituição recíproca em uma estrutura única em que um já afirma o outro:

"Para uma filosofia consciente de si mesma como conhecimento, como fixação de uma experiência prévia, a fórmula: o ser é e o nada não é; é uma idealização, (...) Nosso ponto de partida não será: o ser é o nada não é - nem mesmo só há o ser fórmula de um pensamento totalizante, de sobrevôo - mas há o ser, há o mundo, há alguma coisa, no sentido forte em que o grego fala (...) há coesão, há sentido. Não se faz surgir o ser a partir do nada ex nihilo, parte-se de um relevo ontológico onde nunca se pode dizer que o fundo não seja nada. O que é primeiro não é o ser pleno e positivo sobre o fundo do nada, é um campo de aparências, em que uma delas, tomada à parte, talvez se estilhace ou seja riscada a seguir (é o papel do nada), mas de que somente sei que será substituída por outra, a verdade da primeira, porque há mundo, porque há alguma coisa que, para ser, não precisam, antes, anular o nada." ${ }^{384}$

Nessa passagem central para nós, Merleau-Ponty explicita aquilo que estamos procurando indicar: o Ser do mundo como uma espécie de mediação entre o Ser e o Nada, unidade primária que se configura precisamente por sua negatividade interna. $\mathrm{O}$

\footnotetext{
383 Desenvolveremos essa questão mais adiante.

384 MERLEAU-PONTY, Maurice. O Visivel e o Invisível, São Paulo: Perspectiva, 2007, p. 90 [grifo nosso]
} 
originário não é o puro ser objetivo, mas a inesgotabilidade do processo por meio do qual o Ser se faz, trascende-se e, nesse movimento, se unifica. Estruturado por linhas gerais, ele se modifica parcialmente - se diferencia, se nega - mas por isso mesmo se conserva como totalidade dinâmica e processual. Unidade feita por negação interna, por descentramento ou irradiação, ele é movimento de gênese e auto-instituição contínuo, garantia da impossibilidade de um puro não-ser ${ }^{385}$, afirmação desse Nada constituinte. Nem dado como um objeto, pois há abertura e mudança, e nem abstrato como uma essência subjetiva, pois há coesão intrínseca aos elementos, ele reencontra aquilo que nossas análises anteriores procuraram circunscrever $^{386}$, recusa a ontologia clássica explicitando a abstração de suas construções. Entre o Ser e o Nada, a ontologia de Merleau-Ponty busca o Ser negativo responsável por haver "algo", nem fato e nem ideia pura, mas unidade intrínseca à abertura de seus elementos, Logos primário da experiência ${ }^{387}$ : coesão estruturada pelo distanciamento de seus elementos, sentido feito por negação interna, o Ser é gênese espontânea apoiada na reversibilidade estrutural do Ser e do Nada, instituição que recusa o modelo clássico de constituição ensinando, como veremos, uma unificação que se faz por deiscência e uma nadificação que é estruturante.

385 Explicitaremos esse ponto mais adiante, especialmente ao tratar de modo mais detido da relação entre a parte e o todo.

${ }^{386}$ Conforme nossas análises anteriores. Retomaremos essa questão ao final do capítulo e na conclusão de nosso trabalho.

387 Respeitando a sequência do texto de Merleau-Ponty, essa questão será gradativamente explicitada ao longo do capítulo. 


\section{A redução}

Recusado o positivismo latente das filosofias do negativo, que inviabiliza a abertura própria à fé perceptiva, é preciso explicitar que também as filosofias intelectualistas supõem uma mediação entre o Ser e o Nada, que toda reflexão opera sobre esse há tácito, e a ele permanece vinculada ${ }^{388}$. Como mostrará Merleau-Ponty, a própria dúvida metódica, quando levada ao seu extremo, ao invés de conduzir a um universo separado de essências, acaba se convertendo em confirmação dessa abertura originária e do escopo ontológico por ela implicado.

Toda questão, afirma ele, envolve uma fé fundamental - a fé perceptiva -, convicção de que "existe alguma coisa"389, não podendo ser reduzida nem à ordem do ser puro, pois há afastamento e reflexão, nem à do não ser puro, pois há essa suposição tácita

388 “Toda questão, até mesmo a que diz respeito ao simples conhecimento, faz parte da questão central que somos nós mesmos, deste apelo à totalidade ao qual nenhum ser objetivo dá resposta e que nos cabe agora examinar mais precisamente." (MERLEAU-PONTY, Maurice. O Visível e o Invisível, São Paulo: Perspectiva, 2007, p. 104); e ainda: “(...) mas quem questiona não é nada é - coisa inteiramente diversa - um ser que se interroga; o que possui de negativo assenta numa estrutura de ser, não sendo pois um nada que se elimina do cálculo.” (MERLEAU-PONTY, Maurice. O Visível e o Invisível, São Paulo: Perspectiva, 2007, p. 118)

389 MERLEAU-PONTY, Maurice. O Visivel e o Invisível, São Paulo: Perspectiva, 2007, p. 106 
de um campo em relação ao qual ela se exerce ${ }^{390}$ : "Remetem-nos a não sei que lei de nosso ser, segundo a qual, depois de um espaço, há outro espaço, depois de um tempo outro tempo (...) da interrogação como relação última com o ser e como órgão ontológico"391 . Confirmando a existência latente do mundo para aquém de qualquer juízo, a análise de Merleau-Ponty tornará explícito que todo movimento reflexivo supõe a unidade espontânea do mundo, nutre-se de um Logos originário estruturado pela compossibilidade de seus elementos, garantia de um "há algo" irredutível. Também a reflexão, como veremos, se apóia na abertura ontológica testemunhada pela fé perceptiva para constituir-se, fazendo-se negação circunscrita que nem se identifica e nem recusa seu "objeto".

Escapando simultaneamente do modelo intelectualista e do negativista, a dúvida, ao mesmo tempo que explicita nossa não coincidência com o Ser (assegurando a reflexividade), nos impede de nos retirarmos dele (assegurando a unidade), recusando tanto a identidade quanto a dualidade puras: "Assim como se exclui que a negação seja ruptura real com o Ser, nada vivido, exclui-se também que seja ruptura ideal, olhar absolutamente puro sobre uma experiência reduzida à sua significação ou à sua essência. Assim como se exclui que a questão seja sem resposta, puro abismo abrindo-se em direção a um Ser transcendente, exclui-se também que a resposta seja imanente à questão (...)"392

Assim como não pode recorrer a um "puro abismo", ao Nada absoluto

390 Esse argumento já era indicado na Fenomenologia da Percepção, que mostrava que todo poder suspensivo se alimentava na inserção e no engajamento do ser-no-mundo. Conforme nossa pesquisa de Mestrado (MOURA, Alex de Campos. Liberdade e situação em Merleau-Ponty: uma perspectiva ontológica, São Paulo: Humanitas, 2010).

391 MERLEAU-PONTY, Maurice. O Visivel e o Invisível, São Paulo: Perspectiva, 2007, p. 119

392 Idem, p. 119 
frontalmente oposto ao Ser, a dúvida não pode transformar-se em questão universal, interrogação sobre o "quid sit" ${ }^{\text {"93 }}$, sobre aquilo sem o quê o mundo não seria mundo. Assim como o negativismo acaba por positivar o Ser, as filosofias intelectualistas o mantêm isolado, em um plano inteligível autônomo e idêntico, fazendo da dúvida movimento em direção à positividade das essências abstratas, transformando o pensamento em sentido universal, condição de possibilidade do Ser e dos seres ${ }^{394}$.

Ao contrário, longe de recusar o mundo, uma análise cuidadosa - retomando o movimento já presente na Fenomenologia da Percepção ${ }^{395}$ - deve mostrar que a dúvida envolve necessariamente a unidade do mundo e sua abertura a ele, que as próprias essências se escoram na impossibilidade de um vazio ontológico, explicitando nelas mesmas a unidade do Ser como fundamento último, a crença no mundo como solo de todo processo significativo e de toda articulação. Como veremos, apoiadas sempre na fé perceptiva, também elas permanecerão cativas do Ser, recorrerão ao movimento de estruturação que não provém de si, que descobrem já operantes no mundo e na percepção, evidenciando a impossibilidade de se manter o dualismo entre fato e essência ${ }^{396}$. Assim

393 Idem, p. 108

394 “As essências são esse sentido intrínseco, estas necessidades de princípio, seja qual for a realidade em que se misturam e se confundem (sem que, aliás, suas implicações deixem de fazer-se valer), único ser legítimo ou autêntico que tem a pretensão e direito a ser, e que é afirmativo por si próprio (...)" (MERLEAU-PONTY, Maurice. $O$ Visível e o Invisível, São Paulo: Perspectiva, 2007, p. 108).

395 De acordo como o modo pelo qual a redução é realizada por Merleau-Ponty na Fenomenologia da Percepção, descrito especialmente no Prefácio da obra. Conforme nossa pesquisa de Mestrado (MOURA, Alex de Campos. Liberdade e situação em Merleau-Ponty: uma perspectiva ontológica, São Paulo: Humanitas, 2010).

396 Retomaremos essa questão mais adiante ao tratar da relação entre fato e essência, especialmente por meio da noção de Wesen.

Sobre a necessidade de se explicitar a imbricação recíproca entre fato e sentido, Dastur comenta: "Le problème rencontré ici par Merleau-Ponty est le même que celui qu'a déjà affronté Husserl et qui est en fait 
como é preciso recusar as filosofias do negativo, cabe também afastar-se de seu oposto mas que acaba por chegar a resultados simétricos - o intelectualismo e sua afirmação das essências como pura positividade. Nos dois casos, seja porque se afirma a pura negatividade daquele que pergunta, seja porque o desloca para um universo separado de ideias, a dúvida corte o seu vinculo efetivo com o mundo, e mais uma vez recalca sua abertura ao Ser, mascara a passagem que é precisamente a garantia de sua relação:

"Precisamente para cumprir seu voto de radicalismo, ser-lhe-ia preciso tomar por tema este vínculo umbilical que sempre a liga ao Ser, esse horizonte inalienável, pelo qual ela já está circunscrita, essa iniciação prévia à qual tenta em vão recusar, não mais negar, nem mesmo duvidar, apenas recuar para ver o mundo e o Ser, ou ainda colocá-los entre aspas como fazemos com os enunciados de um outro, deixá-los falar, pôr-se à escuta...."397

Assim, recuperando um procedimento recorrente em sua obra ${ }^{398}$, MerleauPonty procura mostrar que a retomada do movimento reflexivo conduz não à ruptura com o real e com o mundo efetivo, mas à uma redução ${ }^{399}$ capaz de revelar justamente o que lhe le problème le plus ancien de la philophie: celui de la relation entre le fait et l'essence, qu'il ne s'agit pas de considérer comme antithétique l'un par rapport à l'autre, comme Husserl l'a finalement compris, parce qu'alors 'on est finalement conduit a traiter l'essence comme une idée-limite, c'est-à-dire à la faire inacessible', et à mèconnaître que l'essence est non pas au-delà mais au coeur même de l'apparence sensible." (DASTUR, Françoise. chair et langage, Paris: encre marine, 2001, p. 122)

397 MERLEAU-PONTY, Maurice. O Visível e o Invisível, São Paulo: Perspectiva, 2007, p. 107

398 Conforme os capítulos anteriores e nossa pesquisa de Mestrado.

399 Conforme indicado anteriormente, nos parece central o modo pelo qual Merleau-Ponty compreende a redução, pois estaria aí um dos operados que permite afirmar a passagem da fenomenologia ao campo da ontologia (Conforme nossa pesquisa de Mestrado, e indicado nos capítulos anteriores). Como descrevemos anteriormente, para Merleau-Ponty, a redução, ao se deparar com a impossibilidade de se realizar 
resiste, a ecceidade e irredutibilidade do mundo, em um afastamento que torne visível seu movimento de auto-constituição próprio, a dinâmica pela qual o Ser se faz aquém de qualquer deliberação ou de qualquer dúvida subjetiva ${ }^{400}$. Assim como ocorria em seus estudos sobre a percepção ${ }^{401}$, a linguagem ${ }^{402}$ e mesmo no Olho e o Espírito ${ }^{403}$, o filósofo se apropria da "redução fenomenológica" conduzindo-a em outra direção, levando-a ao campo da facticidade e da ontologia ${ }^{404}$ : como alertava já a Fenomenologia da Percepção ${ }^{405}$, o verdadeiro ensinamento da redução, está precisamente na impossibilidade de sua realização completa. Segundo Merleau-Ponty, o recurso reflexivo à dúvida não pode recusar a existência do mundo pois toda redução, toda tentativa de ruptura, mantém o pressuposto de que há algo ${ }^{406}$, detém-se diante de uma articulação espontânea já operante na experiência perceptiva, da qual retira o arquétipo de todo movimento de unificação e de configuração do sentido ${ }^{407}$. O limite da redução não é o retorno do pensamento sobre si completamente, revela a dimensão pré-objetiva que antecede a ruptura completa entre sujeito e objeto.

${ }^{400}$ Conforme nossa pesquisa de Mestrado (MOURA, Alex de Campos. Liberdade e situação em MerleauPonty: uma perspectiva ontológica, São Paulo: Humanitas, 2010).

${ }^{401}$ Conforme nossa pesquisa de Mestrado (MOURA, Alex de Campos. Liberdade e situação em MerleauPonty: uma perspectiva ontológica, São Paulo: Humanitas, 2010).

${ }^{402}$ Conforme os capítulos anteriores.

${ }^{403}$ Conforme o capítulo anterior.

404 De acordo com nossa leitura, indicada nos capítulos anteriores e em nossa pesquisa de Mestrado (MOURA, Alex de Campos. Liberdade e situação em Merleau-Ponty: uma perspectiva ontológica, São Paulo: Humanitas, 2010).

${ }^{405}$ MERLEAU-PONTY, Maurice. Fenomenologia da Percepção, São Paulo: Martins Fontes, 1994, Prefácio

406 Como indicado acima e continuaremos a explicitar ao longo do capítulo.

${ }^{407}$ Merleau-Ponty mostra que é justamente a segurança de que 'há' uma unidade coesa, um "foco virtual", que sustenta o movimento reflexivo em sua tentativa de atingir um naturante universal, apoiando o projeto intelectualista de desfazer-se de sua base mundana. De modo que é sobre o próprio movimento unitário da percepção que se apóiam as pretensões constituintes da subjetividade transcendental: a ideia de uma constituição do mundo, longe de resolver-se em si, opera com esse pressuposto tácito "(...) do mundo como pré-constituído.” (MERLEAU-PONTY, Maurice. O Visivel e o Invisivel, São Paulo: Perspectiva, 2007, p. 43). 
mesmo, mas a explicitação de uma estruturação intrínseca ao mundo e ao sensível, diante da qual cessam os pretensos poderes constitutivos do sujeito ${ }^{408}$. Não é à subjetividade constituinte que a redução nos conduz ${ }^{409}$, mas à estrutura do mundo como auto-constituição e matriz de todo movimento de gênese ${ }^{410}$ : “(...) é preciso que não suspenda a fé no mundo a não ser para vê-o, para ver nele o caminho por ele seguido ao tornar-se mundo para nós, é preciso que nele procure o segredo de nossa ligação perceptiva com ele, que empregue as palavras para dizer essa ligação pré-lógica (...) que o faça dizer, enfim, o que em seu silêncio ele quer dizer... Não sabemos nem o que é exatamente essa ordem e essa concordância do mundo às quais assim nos entregamos." ${ }^{411}$

Assim como ocorria na Fenomenologia da Percepção, em seu ponto extremo, o que a redução revela é o "brotamento imotivado do mundo", unidade ou coesão espontânea que faz com que haja um mundo, haja algo, sem o recurso a uma instância constituinte externa $^{412}$. No ponto cego da torção reflexiva, encontra-se o "há" aberto do Ser

${ }^{408}$ Respeitando o desenvolvimento do texto de Merleau-Ponty, essa questão será explicitada mais adiante.

409 'Quando a filosofia encontra sob a dúvida um 'saber' prévio, em tornos das coisas e do mundo como fatos e como fatos duvidosos, um horizonte que engloba tanto nossas negações como nossas afirmações, quando mergulha nesse horizonte, é certo que deve definir de novo este algo novo. Define-o perfeita ou suficientemente dizendo que é a essência? A questão da essência é a questão última?" (MERLEAU-PONTY, Maurice. O Visivel e o Invisivel, São Paulo: Perspectiva, 2007, p. 109)

${ }^{410}$ Essa questão foi trabalhada mais detidamente nos capítulos anteriores, especialmente em relação à linguagem e a $O$ Olho e o Espírito. Indicada no decorrer do capítulo, respeitando a sequência do texto de Merleau-Ponty, ela será explicitada gradativamente.

${ }^{411}$ MERLEAU-PONTY, Maurice. O Visivel e o Invisivel, São Paulo: Perspectiva, 2007, p. 47

${ }^{412}$ Assim, se a filosofia reflexiva é verdadeira naquilo que nega, na recusa da exterioridade entre o sujeito e o mundo, o percebido e aquele que percebe, isso não autoriza e nem implica necessariamente a passagem à imanência, à ideia da reflexão como um retorno sobre si. Ao contrário, enquanto re-flexão, isto é, enquanto “(...) movimento de retomada, de recuperação, de retorno a si mesmo (...) retorno ou reconquista”, ela não pode ser idêntica ao movimento de constituição e de inauguração, não pode coincidir com a atividade originária de naturação. Nesse sentido, ela "(...) recupera tudo exceto a si mesma como esforço de recuperação, esclarece tudo salvo seu próprio papel". Mesmo em seu esforço de uma conversão completa, a reflexão não pode absorver-se, recusar sua opacidade e sua facticidade, respondendo pelo sentido e pela 
que a ontologia merleau-pontyana busca trazer ao primeiro plano. A redução não implica mais um recurso às puras essencialidades, mas o reconhecimento da pré-existência e da ecceidade daquilo que aparece ao sujeito, 'saber prévio' e horizonte geral que englobam tanto a verdade quanto a ilusão, evidenciando a existência de uma unidade espontaneamente formada, auto-instituição ${ }^{413}$ que não recai na alternativa entre o puro ser e o puro não ser, que põe em suspendo as categorias clássicas e faz um apelo à sua revisão: “(...) Impõe-se-nos, portanto, a tarefa de compreender se, e em que sentido o que não é natureza forma um 'mundo' e, antes de tudo, o que é um mundo, finalmente, se há mundo, quais podem ser as relações entre o mundo visível e o mundo invisível." ${ }^{414}$

Reencontramos desse modo um dos temas centrais de O Visível e Invisível: a necessidade de se compreender o sentido do ser do mundo, o "há" espontâneo desvelado pela fé perceptiva e a ontologia por ele implicada. Retomando uma questão central e constante na obra de Merleau-Ponty - e confirmando, assim, uma de nossas Teses principais -, é a formação espontânea do Ser, o "algo" originário, que se torna preciso compreender. Partindo-se da fé perceptiva, o que se evidencia é a unidade primária da experiência e a "anterioridade" do todo, a instituição do mundo como irredutível.

Somos assim conduzidos à uma unidade que se configura sem o recurso a

razão de sua própria gênese. De modo que não se trata, para Merleau-Ponty, de desqualificá-la, mas de repôla diante da espessura do mundo, da qual emerge e a qual reflete, abertura que a sustenta e a impede de repousar em si.

413 Conforme a noção de instituição proposta pelo filósofo, indicada anteriormente.

414 MERLEAU-PONTY, Maurice. O Visível e o Invisível, São Paulo: Perspectiva, 2007, p. 36 
qualquer tipo de positivismo ou de identidade, sem a suposição do dualismo - entre a parte e o todo, entre o signo singular e o sentido geral ${ }^{415}$ - que demandaria um operador externo de vinculação, uma consciência desengajada que articularia um signo vazio e uma significação inteiramente translúcida para si. Partindo-se da evidência do mundo, a análise da percepção, como veremos, revela uma relação intrínseca entre o parcial e a totalidade, constituição espontânea do todo graças à organicidade estrutural de seus elementos concretos, realizando-se como transcendência interna, negatividade intrínseca que põe em suspenso os parâmetros clássicos ${ }^{416}$ : a instituição do mundo se afirmará não por um ato extrínseco, mas pelo movimento espontâneo em que a singularidade do percebido se abre a uma configuração mais ampla, ata-se ao "há algo" sem o qual permaneceria reduzida à consciência. Como explicitaremos mais adiante, ao tratar da apropriação que Merleau-Ponty faz da noção de Wesen, a parte é uma espécie de irradiação do todo, auto-diferenciação que não nega, mas o afirma indiretamente: distância e transcendência constitutiva da unidade, ela não é mais uma realidade distinta e isolada em si, mas a negação circunscrita que assegura a transição originária entre o parcial e o geral, confirmando o sentido estrutural e constitutivo que o Nada assume na ontologia de Merleau-Ponty:

"Que todo ser se apresente a uma distância que não seja empecilho ao saber, sendo ao contrário, sua garantia, isso nunca se examina. Que justamente a presença

415 Essa questão, como estamos procurando explicitar ao longo da Tese, é uma das linhas centrais da reflexão de Merleau-Ponty.

416 "Desde que se pare de pensar a percepção como ação do puro objeto físico sobre o corpo humano e o percebido como resultado 'interior' dessa ação, parece que toda distinção entre o verdadeiro e o falso, o saber metódico e os fantasmas, a ciência e a imaginação, vem por água abaixo.” (MERLEAU-PONTY, Maurice. O Visivel e o Invisível, São Paulo: Perspectiva, 2007, p. 35) 
do mundo seja presença de sua carne na minha, que eu 'seja ele' e que não seja ele, é o que logo ao ser dito é esquecido: a metafísica permanece coincidência. Que haja essa espessura de carne entre nós e o 'núcleo duro' do Ser, é o que não intervém na definição: essa espessura me é imputada, é o regalo agasalhante de não ser que a subjetividade sempre carrega consigo." 417

Confirmando o sentido ontológico da percepção, o negativo do Ser explicitado por ela é distância e espessura que impedem simultaneamente o Ser-posto (a pura objetividade, pois há espessura intrínseca ao percebido) e o Ser-posicional (a pura subjetividade, pois há distância que impede a coincidência), garantindo a reversibilidade originária dos termos, imbricação de um-no-outro que antecede o dualismo clássico. 0 negativo, aqui, configura uma totalidade em que os termos co-existem e se revertem, graças à "deiscência" ou à negação interna em que o "mesmo" se diferencia, abre-se e reflete-se, mantendo-se contudo inseparável de si mesmo ${ }^{418}$. Será o negativo, como veremos, que responderá, em um só gesto, pela conservação da unidade e por sua reflexividade, sua abertura:

"Quando encontro o mundo atual tal como é, sob minhas mãos, sob meus olhos (...) encontro muito mais do que um objeto: Ser de que minha visão faz parte, uma visibilidade mais velha que minhas operações ou atos. Isso, porém, não quer dizer que haja, de mim para ele, fusão, coincidência: ao contrário, isso se faz porque uma espécie de deiscência fende meu corpo em dois e, entre ele olhando e ele olhado, ele tocante e ele

${ }^{417}$ MERLEAU-PONTY, Maurice. O Visivel e o Invisivel, São Paulo: Perspectiva, 2007, p. 125

${ }^{418}$ Conforme explicitaremos a seguir. 
tocado, há recobrimento e imbricação, sendo, pois, mister dizer que as coisas passam por dentro de nós, assim como nós por dentro das coisas." ${ }^{419}$

Assim, retomando o caminho seguido até aqui, a redução, ao ser levada até suas consequência extremas, conduz ao reconhecimento da auto-constituição do Ser; e esta, por sua vez, implica a existência de um movimento fundamentalmente negativo, estruturação operante pela intermediação e reversibilidade entre o ser e o nada. É esse negativo formativo, essa simultaneidade entre os termos tradicionalmente opostos, que se trata de compreender. Longe da dualidade clássica, o estudo detido da percepção nos ensina a sincronicidade primária entre "transcendência" e "imanência", reflexividade e distância tornadas correlatas. O "originário" não é mais a pura presença ou a pura ausência, nem o oposto e nem o idêntico, mas a clivagem, a diferenciação que não rompe, calcada nessa nova compreensão do negativo: “(...) o originário se cliva, e a filosofia deve acompanhar essa clivagem, essa não-coincidência, essa diferenciação." ${ }^{220}$ A questão portanto passa a ser compreender esse negativo constituinte, distância e diferenciação que "fazem ser", garantia de haver algo, a evidência do mundo e do "há". Examinemos, pois, de modo mais detido, a maneira como a percepção revela essa negatividade originária, explicitando seu movimento de gênese próprio.

Ao perceber, como vimos acima, o olhar se defronta com um visível que parece repousar em si, encontra-se diante dele com uma familiaridade tão estreita como se

\footnotetext{
419 Idem, p. 121

${ }^{420}$ Idem, p. 122
} 
houvesse um recobrimento recíproco, os movimentos dos meus olhos sendo precisamente aqueles de que o visível precisa para manifestar-se, os gestos do corpo aqueles necessários para ver e tocar, sem deliberação consciente, apenas pelo vínculo interno e espontâneo entre um e outro. Proximidade, contudo, que não se torna identificação, pois então a percepção voltaria a ser concebida como imanência ou constituição de seu objeto $^{421}$. Retomando o que suas descrições anteriores haviam indicado ${ }^{422}$, a análise da visão deve explicitar o espaço de mediação entre identidade e alteridade, revelando o movimento único que instaura entre o visível e o vidente simultaneamente uma segregação (impedindo a identidade) e uma reflexão (impedindo a exterioridade): ela deve, pois, confirmar essa negatividade estrutural, confirmando a distância que é abertura, o horizonte que é "presentabilidade do inapresentável".

Ao ver, mostra Merleau-Ponty retomando o argumento de $O$ Olho e o Espírito, encontro a coisa vista no termo de meu olhar, no limite de meus movimentos, mas encontro-a justamente como aquilo que o ultrapassa: mantida do limite de minha exploração perceptiva, ela se oferece como mais do que o simples correlato de minha visão, sendo na verdade aquilo que a impõe a $\operatorname{mim}^{423}$. O paradoxo constitutivo da percepção é que, do interior de sua singularidade, ela se abra a um todo, transcenda em direção a uma unidade mais ampla da qual participa mas que não absorve, abertura a um mundo que se oferece a mim em sua ecceidade. Não se trata da afirmação de um "em-si-para-nós" ${ }^{424}$, que manteria

${ }^{421}$ Conforme indicado acima e como foi explicitado nos capítulos anteriores, em que o tema da percepção também foi trabalhado.

${ }^{422}$ Conforme trabalhado acima e conforme a análise que fizemos no capítulo anterior sobre O Olho e o Espírito.

${ }^{423}$ MERLEAU-PONTY, Maurice. O Visível e o Invisível, São Paulo: Perspectiva, 2007, p. 128

${ }^{424}$ Aqui é um dos pontos em que se pode notar um afastamento em relação às descrições - sobretudo do ponto 
no limite o pressuposto tácito dualista, mas da explicitação da reversibilidade primária entre o singular e o geral que desconhece a cisão entre o em-si e o para-si, reconhecimento desse Logos espontâneo do mundo calcado na passagem intrínseca entre a parte e o todo. Como vimos, a análise intelectualista, com sua suposição da subjetividade como instância constituinte, afirma um sentido extrínseco ao mundo e ao sensível, faz da significação um produto da consciência que nada deve ao concreto e ao signo, puro ideado constituído de ponta à ponta; mantém assim a suposição do subjetivo e do objetivo como esferas completamente diversas, fazendo da realidade uma construção do pensamento. Para Merleau-Ponty, ao contrário, a fé perceptiva, em seu reconhecimento de um "algo" originário - isto é, em sua abertura a uma totalidade significativa espontaneamente formada - explicita um sentido que é intrínseco ao real, recusa sua concepção como objeto e a correlata afirmação do sujeito como constituinte. Ela evidencia que a articulação do diverso, a estruturação da experiência, são dinâmicas próprias ao mundo, não dependentes de uma operação intelectual| ${ }^{425}$. O que faz com que a realidade seja coesa e articulada não

de vista terminológico - da Fenomenologia da Percepção, pois era precisamente como "em-si-para-nós" que a coisa era então descrita por Merleau-Ponty. Segundo nossa hipótese de trabalho, que estamos procurando sustentar ao longo da Tese, trata-se mais de uma diferença terminológica do que propriamente teórica. Como procuramos indicar, julgamos na verdade que a revisão terminológica decorre do movimento conceitual presente desde as primeiras obras, respondendo à uma necessidade por elas mesmas imposta. Barbaras, ao comentar as insuficiências da Fenomenologia da Percepção, aponta sua incapacidade de problematizar filosoficamente o campo desvelado pelo estudo da percepção (Conforme: De l'être du phénomène, Granoble: Millon, 1991). Discordamos da interpretação do autor, pois além de sua análise não levar em conta a questão da temporalidade - operador central, a nosso ver - é preciso considerar a dimensão crítica do pensamento de Merleau-Ponty, isto é, o fato dele partir do campo adversário, de suas contradições internas, para construir sua reflexão, de modo que o "em-si-para-nós", mais do que uma solução definitiva, seria a explicitação de uma tensão, de uma questão que as obras posteriores viriam tentar responder: a impossibilidade de se manter o dualismo clássico, e a necessidade de uma revisão das categorias da Tradição.

${ }^{425}$ Respeitando o desenvolvimento do texto de Merleau-Ponty, o modo como isso ocorre será explicitado mais adiante. 
é uma atividade externa, mas o fato mesmo dela ser real, quer dizer, é por ser real que ela é coerente e não o contrário ${ }^{426}$. Invertendo o parâmetro clássico, o pressuposto da razão subjetiva como fundamento do Logos, a ontologia de Merleau-Ponty faz da realidade do mundo a matriz da coesão e do processo de articulação significativa. ${ }^{427}$

Não são as atividades da consciência que asseguram a significação do "objeto", mas, como veremos, é a estrutura do Ser que sustenta toda "síntese espontânea", princípio de unificação do diverso e das operações do pensamento: o originário não é uma agregação de partes vazias justapostas, mas o movimento interno de articulação em que se institui um sentido comum, o "há" primário que envolve toda singularidade. Retomando uma das questões centrais de sua filosofia ${ }^{428}$, o mundo é compreendido por Merleau-Ponty como "berço" do movimento de significação, arquétipo da racionalidade: “(...) é necessário compreender que o mundo sensível é essa lógica perceptiva, sistema de equivalências, e não um amontoado de indivíduos espacio-temporais. E essa lógica não é nem produto da constituição psicofísica, nem produto de nossa aparelhagem categorial mas antecipaçãolevantamento sobre um mundo cuja membrura não é explicitada pelas nossas categorias, nossa 'constituição', nossa subjetividade"429 . Movimento espontâneo de articulação apoiado na configuração aberta de seus elementos, o mundo é unidade aberta que se forma pela reversibilidade intrínseca entre o singular e o geral, transição orgânica entre a parte e o

${ }^{426}$ MERLEAU-PONTY, Maurice. O Visível e o Invisível, São Paulo: Perspectiva, 2007, p. 48

427 Conforme explicitaremos mais adiante.

Esse é, em nossa leitura, um dos pontos principais da ontologia de Merleau-Ponty, conforme estamos procurando explicitar ao longo da Tese. Retomaremos essa questão na conclusão.

428 Conforme indicado na nota anterior.

${ }^{429}$ MERLEAU-PONTY, Maurice. O Visivel e o Invisível, São Paulo: Perspectiva, 2007, p. 225 
todo: "A menor parcela do percebido o incorpora de imediato ao 'percebido', o fantasma mais verossímil escorrega na superfície do mundo; é esta presença do mundo inteiro num reflexo, sua ausência irremediável nos delírios mais ricos e mais sistemáticos que devemos compreender."

Assim, diante de um dos eixos da analítica fenomenológica ${ }^{431}$, Merleau-Ponty reconfigura a relação entre o todo e as partes de modo a explicitar a existência de uma passagem espontânea entre eles, estrutura própria ao mundo, não mais dependente de uma subjetividade constituinte, respondendo pela configuração simultaneamente aberta e unitária do sensível. Entre o singular e a totalidade, não se estabelece mais a distinção completa do para si e do em si, do sentido e do signo, mas apenas diferenças reversíveis no interior de um mesmo algo, de um mundo que envolve e unifica o diverso sem destituí-lo de sua particularidade: "(...) [o mundo é] o lugar de sua compossibilidade, o estilo invariável que observam, que unifica nossas perspectivas, permite a transição de uma a outra e nos dá o sentimento (...) de sermos duas testemunhas capazes de sobrevoar o mesmo objeto

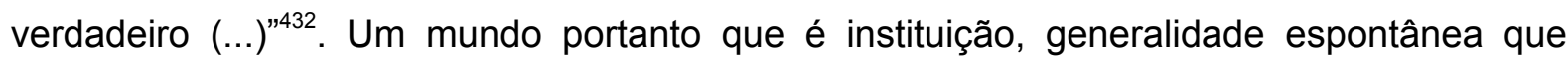
unifica os dados dentro de um conjunto aberto, mas coerente: totalidade que se faz pela transição de seus elementos, ele opera por diferenciação interna que vincula os termos como entidades diacríticas, referenciais - conforme as análises anteriores e como explicitaremos mais adiante ao tratar da noção de Wesen. Retomando uma linha constante

\footnotetext{
430 Idem, p. 48

431 Conforme indicado acima.

${ }^{432}$ MERLEAU-PONTY, Maurice. O Visivel e o Invisivel, São Paulo: Perspectiva, 2007, p. 24
} 
em sua reflexão ${ }^{433}$, a parte se revela então como uma entidade diacrônica, transcendência espontânea que necessariamente remete para além de si, para uma totalidade que a ultrapassa; correlativamente, o todo passa a se apresentar como estrutura dinâmica, aberta, feita pela constância de seu movimento de diferenciação, ambos portanto distantes da identidade ou do positivismo. O que se afirma, pois, não é o mundo como entidade imutável, mas sim como constância ou forma geral do movimento originário de diferenciação, transcendência ininterrupta e por isso mesmo irrecusável, unitária em seu movimento de afastar-se de si: como veremos, é justamente a diacronia e a abertura do Ser que impedem a aparição do puro não-ser, assegurando a permanência de seu próprio fluir, configuração de "algo" para aquém de qualquer ruptura deliberada:

"Pois quando uma ilusão se dissipa, quando uma aparência irrompe de repente, é sempre em proveito de uma nova aparência que retoma por sua conta a função ontológica da primeira (...) A irrupção e a destruição da primeira aparência não permitem doravante definir o real como simples provável, porquanto eles não são mais do que outros nomes da nova aparição que deve, pois, figurar em nossa análise da des-ilusão. A desilusão só é perda de uma evidência porque é a aquisição de uma outra evidência." ${ }^{434}$

Contra a teoria que deduz, a partir da possibilidade de um imaginário e de uma resignificação dos fatos, que o mundo é apenas provável, que seu sentido lhe é extrínseco e dependente das deliberações do sujeito, Merleau-Ponty mostra que a ilusão, longe de recusa do sentido do mundo, recorre a ele para configurar-se, nutre-se de sua

433 Conforme nossa hipótese de trabalho que estamos procurando explicitar ao longo da Tese.

${ }^{434}$ MERLEAU-PONTY, Maurice. O Visível e o Invisível, São Paulo: Perspectiva, 2007, p. 48 
transitoriedade e de sua abertura para constituir-se. Longe da afirmação de um puro Nada que recusaria o Ser, que o significaria livremente ${ }^{435}$, o imaginário agora está inscrito na estrutura aberta do real. A ilusão só se configura como tal porque necessariamente ela será sucedida por algo diverso, novo, mas que por isso mesmo confirma a permanência geral do processo de vir-a-ser, e com ele a impossibilidade do "vazio ontológico", do Nada absoluto. Contra a afirmação do negativo como recusa do Ser, o imaginário e a ilusão são agora negações no Ser: se implicam uma distância, eles o fazem confirmando a constância e a ecceidade do todo; só valendo como tais por aparecem sobre um fundo irredutível que modulam mas não abandonam. A des-ilusão é perda de uma evidência porque há a aquisição de outra, porque "há" uma trama que a liga à unidade do real. Assim, ao invés de recusa da fé perceptiva e da evidência do mundo, a possibilidade da ilusão e da des-ilusão não faz senão confirmá-las:

“Cada percepção é mutável e somente provável; isto, se quisermos, não passa de uma opinião; mas o que não o é, o que cada percepção mesmo falsa verifica é a pertença de cada experiência ao mesmo mundo, seu poder igual de manifestá-lo, a título de possibilidades do mesmo mundo. Se uma toma tão bem o lugar da outra (...) é que

${ }^{435} \mathrm{O}$ alvo principal de Merleau-Ponty aqui parece ser Sartre, com sua compreensão do imaginário como instância autônoma, tributária apenas do para-si. Conforme indicado no capítulo anterior, esse tema foi apontado pelo autor também em $O$ Olho e o Espírito. Em ambos os momentos, divergindo da análise sartreana, Merleau-Ponty propõe uma espécie de reversibilidade estrutural entre o real e o imaginário, afirmando uma constituição recíproca entre eles. Isso implica que o gesto de criação, o movimento significativo, permanece dotado de uma certa passividade, tributário de algo que lhe advém do real e da situação em que se encontra. Como indicamos anteriormente, para Sartre, ao contrário, a autonomia do imaginário é equivalente à autonomia da liberdade, expressão da pura atividade subjetiva que se revela em um processo de significação que nada deve ao em-si. (Conforme, por exemplo, O Ser e o Nada, Rio de Janeiro: Vozes, 1999). 
precisamente não são hipóteses sucessivas concernentes a um Ser não-conhecível, mas perspectivas sobre o mesmo Ser familiar, o qual, sabemos, não pode excluir uma sem incluir a outra e, em qualquer situação de causa, está fora de contestação." 436

Desse modo, do caráter transitório e mutável da percepção, não se pode concluir que não haja uma verdade mais ampla da qual ela participa, uma unidade que a envolve e significa. Ao contrário, como já ocorria anteriormente ${ }^{437}$, a questão é compreender que se trata de um outro tipo de unidade, que assimila a transformação e recorre à ela para constituir-se. A parcialidade de cada percebido, a possibilidade de ilusões e recuos, não são a recusa do mundo, mas seu avesso, o movimento possível graças à unidade primária que absorve toda metamorfose, ao mesmo tempo assegurando-a em sua singularidade e estruturando-a como momento do todo. Como estamos procurando indicar, a ontologia merleau-pontyana reconfigura o mundo e o real de modo a reconhecer neles uma passagem e uma distância intrínsecas, negatividade que não recusa, mas afirma o Ser, afastando-se da dicotomia entre homem e mundo, não afirmando mais um Nada que expressaria o puro para-si, mas a estrutura constitutiva de um Ser aberto e reversível: "(...) cada percepção é o termo de uma aproximação, de uma série de 'ilusões', que não eram apenas simples 'pensamentos', no sentido restritivo de Ser-para-si e do 'nada mais que pensado', mas possibilidades que poderiam ter sido, irradiações desse mundo único que 'há'... - e que desse modo nunca retornam ao nada ou à subjetividade, como se nunca

436 Idem, p. 49

437 Conforme indicamos em nossa pesquisa de Mestrado (MOURA, Alex de Campos. Liberdade e situação em Merleau-Ponty: uma perspectiva ontológica, São Paulo: Humanitas, 2010) e conforme nossa Tese que estamos procurando sustentar. 
tivessem aparecido, sendo antes, como bem diz Husserl, 'riscadas' ou 'barradas' pela 'nova' realidade." ${ }^{438}$

O que a percepção atesta, o que a "tolerância" do mundo implica, não é um puro não-ser posto diante do Ser puro, mas sua imbricação e reversibilidade, movimento constante de diferenciação que jamais se detém em uma pura negatividade. Trata-se de reconhecer uma "fissão" ontológica que escapa à alternativa entre imanência e transcendência, unidade aberta estruturada por seu caráter reflexivo ${ }^{439}$ e transitório. Nessa perspectiva, o negativo será "irradiação" do todo, sua confirmação, justamente enquanto transcendência e horizonte que asseguram a distância interna que sustenta sua ecceidade, profundidade que o faz escapar a uma apreensão ou constituição externa. O Nada é agora expressão da abertura constitutiva do Ser, reversibilidade que faz da parte - o visível, o percebido - referência espontânea ao geral, ao sentido e à unidade mais ampla da qual se segrega: “(...) [a percepção] é a pré-posse de uma totalidade, que está ai antes que se saiba como e por que, cujas realizações nunca são o que teríamos imaginado que fossem e que, contudo, preenche em nós uma espera secreta já que nela acreditamos infatigavelmente." ${ }^{400}$ Instituição assegurada por essa negatividade que não rompe, mas afasta, distância e por isso mesmo relaciona, a percepção será apresentação de um “inapresentável”, reversibilidade que faz a passagem do visível ao invisível, abrindo a um todo que não pode ser propriamente dado, jamais inteiramente manifesto. Assim, o que

${ }^{438}$ MERLEAU-PONTY, Maurice. O Visivel e o Invisível, São Paulo: Perspectiva, 2007, p. 49

439 Reflexividade, como explicitaremos adiante, não no sentido de um movimento abstrato, mas como dinâmica inscrita na carne, operando uma profunda subversão do modelo clássico.

${ }^{440}$ MERLEAU-PONTY, Maurice. O Visível e o Invisível, São Paulo: Perspectiva, 2007, p. 50 
assegura a unidade do mundo, a ecceidade do sensível, é justamente a transcendência ou o horizonte espontâneo que reveste a parte e a revela dimensão de uma estrutura mais ampla. Como dirá Merleau-Ponty, concebendo a nova terminologia de sua ontologia, o que sustenta o visível em sua evidência e ecceidade é precisamente o invisível, o todo latente em sua profundidade e infatigável reversibilidade, garantia do "há" de todo o sensível, unidade maciça que engloba a diferença e nutre-se dela para se configurar:

"Temos então: abertura para o próprio cubo através de uma visão do cubo que é distanciamento, transcendência (...) Eu, minha visão, estamos com ele presos ao mundo carnal; i.e.: também minha visão e meu corpo emergem do mesmo ser que é, entre outras coisas, cubo - A reflexão que os qualifica como sujeitos de visão é essa mesma espessa reflexão que faz com que eu me toque tocando, i.e., que o mesmo em mim seja visto e vidente: não me vejo vendo, mas por imbricação, realizo meu corpo visível, prolongo meu ser visto para além do meu ser-visto para mim. E é para mim, para minha carne, meu corpo de visão, que pode existir aquele cubo que finaliza o circuito e completa meu servisto. É, enfim, a unidade maciça do Ser que me engloba a mim e ao cubo, é o Ser selvagem, não-depurado, 'vertical', quem faz com que haja um cubo." ${ }^{441}$

Cabe pois examinar, de modo mais detalhado, a maneira pela qual se estabelece essa relação ontológica entre o visível e o invisível, abertura estrutural entre a parte e o todo, especialmente através da apropriação que Merleau-Ponty faz da noção de Wesen, meio termo entre essência e existência.

441 Idem, p. 191 


\section{Wesen}

Vimos acima que a unidade do mundo se apóia na reversibilidade originária entre a parte e o todo, movimento negativo cuja dinâmica procuraremos agora explicitar, confirmando a reconfiguração ontológica que nossas análises têm apontado. Como indicado, trata-se de uma unidade que se constitui por sua negatividade interna, "fissão" em que se dilata e descentra sem abandonar-se, realizando uma passagem espontânea entre o singular e o geral: cada parte, nela, será simultaneamente estrutura, cada percebido dimensão. Em lugar da exterioridade, o que se afirmará é a transição contínua de um a outro, figurada nas noções de carne e de elemento, na reversibilidade estrutural entre o visível e o invisível. Como estamos procurando mostrar ao longo do texto, operando a mediação entre o Ser e o Nada, esse Ser se afasta das noções de sujeito e objeto, é instituição $^{442}$, a um só tempo dimensionalidade geral e diferença singular. Na ontologia desdobrada pela análise do sensível o originário não é a subjetividade posta diante do objeto, mas a unidade espontânea que se transcende em momentos singulares, sob

${ }^{442}$ Conforme indicado anteriormente. 
diferentes "raios", estilo de articulação e de composição constante que ora se concentra, ora se generaliza; movimento geral que, ao diferenciar-se, se confirma:

"Não há um ponto do espaço e do tempo que não se relacione com os outros, que não seja uma variante dos outros (...) não há um indivíduo que não seja representativo de uma espécie ou de uma família de seres, que não tenha, que não seja, um certo estilo, uma certa maneira de gerir o domínio do espaço e do tempo sobre o qual tem competência, de pronunciá-lo, de articulá-lo, de irradiar em volta de um centro inteiramente virtual, em suma, uma certa maneira de ser, no sentido ativo, um certo Wesen no sentido, diz Heidegger, que tem a palavra quando empregada como verbo.,"443

Um dos pontos centrais para a compreensão dessa unidade ontológica é a maneira pela qual Merleau-Ponty se apropria da noção de Wesen. Como afirma Chauí ${ }^{444}$, ele oscila entre o sentido que o termo adquire em Heidegger e Husserl, tomando-o ora como essência, relacionado à redução eidética husserliana, ora como Wesen verbal, relacionado à analítica heideggeriana sobre a linguagem, isto é, ora como noema, ora como modo ativo de ser. Concordamos com a interpretação da autora, segundo a qual propositadamente Merleau-Ponty transita entre os dois usos, estabelecendo uma espécie de indistinção ${ }^{445}$, pois trata-se, a nosso ver, justamente de explicitar a indissociabilidade

443 Idem, p. 114

444 CHAUÍ, Marilena de Souza. Experiência do Pensamento, São Paulo: Martins Fontes, 2002

445 Conforme indicado por Chauí em seu ensaio Experiência de Pensamento: "Em nosso entender, o aspecto mais paradoxal do texto, porém, parece estar num uso indiscriminado da essência como Wesen verbal, no sentido heideggeriano, e como noema, no sentido do Wesen husserliano (...) Pensamos contudo que a 'indistinção' é propositada e que Merleau-Ponty toma o Wesen husserliano - definido como in-variante e não como ser positivo -, de sorte que o force até converter-se no Wesen heideggeriano (...) tudo indica que, para Merleau-Ponty, a Wesenschau husserliana desemboca por si mesma no Wesen heideggeriano, de sorte que não estamos diante de duas concepções antagônicas de essência, mas perante uma preparação-antecipação do 
entre um e outro, indicando uma essência que só se realiza "sendo" efetivamente, e um "ser" ativo que estruturalmente se transcende e se articula em sentido - isto é, retomando o eixo que seguimos até aqui, um singular que espontaneamente se generaliza, e uma generalidade que espontaneamente se particulariza.

Como apontado nas análises anteriores, é precisamente essa estrutura reversível do Ser que a percepção traz ao primeiro plano. Quando percebo algo, a cor vermelha por exemplo, eu não tenho acesso a um objeto destacável, a um quale que minha consciência desdobraria diante de si. Retomando uma das bases de sua analítica sobre a percepção - presente desde a Estrutura do Comportamento e a Fenomenologia da Percepção $o^{446}$ - todo percebido é figura sobre um fundo, é estrutura ${ }^{447}$, referência para além de si. Quando vejo a cor, vejo uma certa modulação do vermelho que se liga a um contexto específico, uma configuração afetiva, social e histórica, como o vermelho da bandeira da China que não é exatamente o "mesmo" vermelho reconhecível em um vestido de festa, diferentes significações e valores.

Em cada vermelho percebido, desdobra-se uma maneira singular do Ser

Wesen verbal no noema." (CHAUÍ, Marilena de Souza. Experiência do Pensamento, São Paulo: Martins Fontes, 2002, p . 90, 91)

446 "Quando a Gestaltheorie nos diz que uma figura sobre um fundo é o dado sensível mais simples que podemos obter, isso não é um caráter contingente da percepção de fato, que nos deixaria livres, em uma análise ideal, para introduzir a noção de impressão. Trata-se da própria definição do fenômeno perceptivo, daquilo sem o que um fenômeno não pode ser chamado de percepção. $O$ 'algo' perceptivo está sempre no meio de outra coisa, ele sempre faz parte de um campo." (MERLEAU-PONTY, Maurice. Fenomenologia da Percepção, São Paulo: Martins Fontes, 1994, p. 24).

${ }^{447}$ A discussão sobre a estrutura é um dos temas centrais e constantes da filosofia de Merleau-Ponty. Procuramos indicá-lo em nossa pesquisa de Mestrado (MOURA, Alex de Campos. Liberdade e situação em Merleau-Ponty: uma perspectiva ontológica, São Paulo: Humanitas, 2010), procurando explicitar sua dimensão ontológica. 
vermelho geral realizar-se. Assim, por sob a cor vista, opera uma estrutura mais ampla que se particulariza sem abandonar-se, espécie de horizonte frente ao qual a singularidade ganha relevo e forma: "age" ${ }^{448}$, sob o visível, uma dimensionalidade, um não-visível que o sustenta, a "essência" que o garante como vermelho, isto é, que estabelece os contornos gerais e permanentes que o diferenciam das outras cores. Cada percebido aparece não como uma entidade positiva e isolável, mas como variação dessa dimensionalidade mais ampla, capaz de se focar em uma forma particular mantendo-se dilatada em um espaço e tempo generalizados. Por sob o efetivamente visível, e sustentando-o, há pois o horizonte de latência, invisível: no vermelho visto, opera o Wesen do vermelho, a "essência" geral que "é" concretamente em cada uma de suas figuras.

Essência que se efetiva, transcendência que ao modalizar-se se faz visível, o Wesen percebido confirma o caráter auto-geracional do Ser, a ecceidade do sensível. Posto entre a generalidade husserliana e a atividade heideggeriana, ele é agora uma certa maneira de "fazer ser", no sentido ativo que tem a palavra quando empregada como verbo, isto é, como irradiação que "propaga" sua estrutura fazendo-a existir concretamente: o Wesen do vermelho é uma certa maneira de "avermelhar" - como em Heidegger ${ }^{449}$, o

448 No sentido em que Merleau-Ponty se apropria da palavra como verbo heideggeriana.

449 A aproximação de Merleau-Ponty, em especial de $O$ Visível e o Invísivel, com Heidegger tem sido tema constante de muitos estudos. Ela é indicada, por exemplo, por DASTUR, em seu livro "chair et langage", no qual a autora afirma haver mesmo uma "virada" no final da obra de Merleau-Ponty, como uma passagem em direção à Heidegger: "Ce tournant, c'est donc bien aussi celui qui fait passer Merleau-Ponty de Husserl à Heidegger, comme l'attestent ses derniers cours au Collège de France” (p.10). Outros autores, como por exemplo HAAR (Proximity and distance, IN: Merleau-Ponty and the possibilities of philosophy, New York: State University of New York, 2009), tratam das influências heideggerianas nas últimas reflexões de Merleau-Ponty. De modo geral, como afirma SAINT-AUBERT (Vers une ontologie indirecte) parece haver uma tendência em reconhecer essa aproximação: “On a souvent pensé que l'entreprise ontologique de Merleau-Ponty s'ouvrait, sous l'influence de Heidegger, dans un net recul à l'egard du registre 
Wesen da mesa é um modo de "mesificar" ${ }^{\text {"450 }}$, como a "roseidade" que se estende através da rosa -, gênese constante e espontânea feita pela reversibilidade entre o geral e o singular, ação estrutural de uma dimensionalidade que se transcende no particular e nele se faz parcialmente visível.

Assim, minha percepção não é abertura ao simplesmente visível, mas à transcendência que o sustenta e que nele se efetiva, a uma maneira de tornar visível, essência ativa que "faz ser" e "dá à ver"; ela é, enfim, percepção do invisível constitutivo de toda visibilidade. Como em O Olho e o Espírito, em que a visão do pintor é descrita não como acesso ao visível, mas àquilo que o faz visível, aos meios pelos quais a visibilidade se oferece à visão $^{451}$, também aqui trata-se de reconhecer a auto-constituição do visível,

'antropologique', certaines formules de l'auteur induisant cette interpretation. ” (p. 19)

O próprio Saint-Aubert porém, parece relativizar essa proximidade, mostrando uma certa divergência, sobretudo em relação à prática de uma ontologia efetivamente indireta por parte de Heidegger (p. 118), e chamando a atenção para o fato de que a questão central para Merleau-Ponty continua sendo a "reabilitação ontológica do sensível", ao passo que em Heidegger ela permanece um tema lateral, de certo modo diluído em uma perspectiva mais ampla: "Son ontologie n'est pas la réecriture tardive d'une philophie dans une autre, aprés un deplacement majeur où siégerait l'ombre de Heidegger, et d'où serait évacué l'essentiel de la pensée de Merleau-Ponty, à savoir la 'réhabilitation ontologique du sensible' ('réhabilitation', et non traduction ou retranscription), la chair du monde où se joue l'unité de l'homme. De son côté, l'entreprise heideggérienne ne saurait être une réhabilitation ontologiue du sensible qu'en taisant la chair comme ce qui est trop difficile à penser, ce dont on ne peut parler.” (p.149)

Apenas como indicação, julgamos, como apontam por exemplo MOURA (Racionalidade e crise), BESMER (Merleau-Ponty's Phenomenology) e CHAUÍ (Experiência do pensamento), que é preciso sempre considerar a relevância central de Husserl no interior da reflexão de Merleau-Ponty. Como afirma RICOEUR, nos parece que mais do que optar entre um e outro, a filosofia de Merleau-Ponty busca propor a "convergência" entre as filosofias de Heidegger e Husserl, movendo-se entre elas (Conforme: RICOEUR, Merleau-Ponty beyond Husserl and Heidegger, IN: Merleau-Ponty and the possibilities of philosophy, New York: State University of New York, 2009)

Sobre a relação de Heidegger com a filosofia francesa, especialmente o modo como ele é recebido por ela, ver por exemplo: PETTIGREW, David; RAFFOUL, François (eds.). French interpretations of Heidegger, New York: State University of New York, 2008

${ }^{450}$ MERLEAU-PONTY, Maurice. O Visível e o Invisível, São Paulo: Perspectiva, 2007, p. 170

${ }^{451}$ Conforme trabalhado no capítulo anterior. 
reencontrando o paradoxo de que ver não é apropriar-se, mas "ter à distância", não identificar-se, mas abrir-se à fissão do $\operatorname{Ser}^{452}$, ao negativo que o faz ser. Assim como o azul do riacho das Lavadeiras de Renoir tratado na Prosa do Mundo ${ }^{453}$ provém de uma certa "típica" que o artista apreende do próprio mar, de uma estrutura do Ser azul apoiada em uma lógica intrínseca ao percebido - instituição ou matriz simbólica ${ }^{454}$-, é preciso reconhecer também aqui um universo próprio ao vermelho que sustenta seus diferentes modos de ser, horizonte que espontaneamente transborda em cada uma de suas "partes", respondendo pelo seu poder-ser próprio. A reversibilidade entre o geral e o singular, a essência e o concreto, responde por um movimento de auto-constituição originário. Mantendo-se o exemplo da cor, Merleau-Ponty mostra que na percepção do amarelo coexistem e se constituem reciprocamente o universal e o particular: na singularidade percebida age - novamente no sentido do verbo, de tornar amarelo - uma dimensionalidade mais ampla, horizonte geral do amarelo frente ao qual o percebido se diferencia e se configura, estrutura geral ou típica da cor, evidenciando a simultaneidade entre facticidade e "essência":

"Ora, essa particularidade da cor, do amarelo, e essa universalidade não estão em contradição, são conjuntamente a própria sensorialidade: é pelo mesmo motivo que a cor, o amarelo, se dá, ao mesmo tempo, como certo ser e uma dimensão, a expressão de todo o ser possível - É próprio do sensível (como da linguagem) ser

452 Conforme indicado no capítulo anterior.

453 MERLEAU-PONTY, Maurice. A prosa do mundo. São Paulo: Cosac \& Naify, 2002

${ }^{454}$ A compreensão merleau-pontyana da instituição como matriz simbólica foi trabalhada nos capítulos anteriores. 
representativo do todo não através da relação signo-significação ou por imanência das partes uma nas outras e no todo, mas porque cada parte é arrancada ao todo e vem com as raízes, coincidir lentamente com o todo, viola as fronteiras das outras."

Longe da noção de um ser-em-si, o que caracteriza agora o Ser do mundo é a abertura estrutural que o coloca entre o "ser" efetivo e a dimensão, simultaneamente parcial e total, não operando mais com a cisão entre um e outro: cada parte arrancada do todo, o traz por justaposição e invasão; é já uma de suas realizações possíveis enquanto latência e invisibilidade operante. Não há dualismo porque é do interior de sua particularidade que o amarelo se faz dimensão, que a cor vista se escora na dimensão não visível para singularizar-se.

Assim, recusando uma vez mais o modelo clássico, a passagem do signo ao sentido, da parte ao todo, não é mais tributária de uma subjetividade desengajada, a representação não é mais uma operação externa de constituição, mas estrutura espontânea de um Ser cuja negatividade o impede de repousar ou negar-se completamente, feito pela abertura constitutiva por meio da qual o parcial se faz sentido e vice-versa. A unificação, a articulação de um sentido constante, não implica mais o recurso ao transcendental puro, mas esse movimento espontâneo de transcendência e de "transgressão" próprio ao Ser, que faz de cada parte uma irradiação do todo. A "marcha" em direção ao geral é agora abertura à profundidade do Ser, ao "universal abaixo de nós", que está aí antes de nossas deliberações subjetivas, pré-constituição espontânea. Invertendo o paradigma dualista

${ }^{455}$ MERLEAU-PONTY, Maurice. O Visivel e o Invisivel, São Paulo: Perspectiva, 2007, p. 202 
clássico, a unidade defendida pela ontologia de Merleau-Ponty se faz por invasão e reversibilidade, é primária, transposição originária de "um-no-outro" ${ }^{456}$. Calcado na transição interna do singular ao geral, o movimento de "síntese" não implica mais um salto no puro espiritual, pois agora a transitoriedade é dinâmica inscrita na estrutura ontológica do sensível e do mundo: "O 'Mundo' é este conjunto onde cada 'parte', quando a tomamos por si mesma, abre de repente dimensões ilimitadas, - torna-se parte total ${ }^{p 457}$. Nem em-si e nem para-si, nem síntese e nem constituição, o recurso ao Wesen solidifica o delineamento de uma alternativa à ontologia clássica, confirmando a unidade espontânea cuja reversibilidade estrutural desconhece a cisão dos termos tradicionalmente opostos:

"A descoberta do Wesen (verbal): primeira expressão do ser que não é nem ser-objeto nem ser-sujeio, nem essência nem existência: o que west (o ser-rosa da rosa, o ser-sociedade da sociedade, o ser-história da história (...) é a roseidade se estendendo através da rosa, é o que Bergson chamava bastante mal de imagens - Que, por outro lado, essa roseidade dê lugar a uma ideia geral, isto é, que haja diversas rosas, uma espécie rosa, isso não é indiferente, mas resulta do ser rosa considerado em todas as suas implicações (geratividade natural) - Por aí - cortando toda generalidade da definição primeira do Wesen - suprime-se essa oposição entre fato e essência que tudo falseia (...) Wesen da mesa \# um ser em si, onde os elementos se disporiam, \# um ser para si, uma Sinopse = o que nela 'mesifica' o que faz com que a mesa seja mesa." ${ }^{\text {} 458}$

\footnotetext{
${ }^{456}$ Como explicitaremos a seguir.

457 MERLEAU-PONTY, Maurice. O Visível e o Invisível, São Paulo: Perspectiva, 2007, p. 202

458 Idem, p. 170
} 


\section{A Carne}

Assim, na nova ontologia proposta por Merleau-Ponty, o originário não é a dualidade do para si e do em si, do sentido geral e da particularidade concreta, mas essa unidade aberta do Ser desvelada pela percepção, dimensionalidade operante que a faz transcender rumo a um todo sempre latente, Wesen ou estrutura que se singulariza preservando sua generalidade, unidade primária. Se a percepção não pode ser uma relação com objetos, é porque originariamente não há objetos, mas um único Ser que se diferencia, que se estrutura por irradiação sem nenhuma identidade possível. Como vimos, cada percebido se revela uma distância ou uma diferenciação do mesmo algo: o visível que meus olhos alcançam não é um átomo, mas um "nó no simultâneo e no sucessivo" ${ }^{\text {459 }}$. Sua forma permanece solidária da textura mais ampla que a envolve, ao mesmo tempo atada e diferida $^{460}$, confirmando a totalidade e o "há" do mundo: "A percepção é primeiramente não percepção das coisas mas percepção dos elementos (água, ar...) de raios do mundo, que

459 Idem, p. 129

460 Esse estatuto da coisa ficará mais claro logo abaixo quando tratarmos do corpo, compreendido como "(...) coisa no mais alto grau: um isto dimensional", isto é, como simultaneidade do singular e do geral, reversibilidade de um no outro, ao mesmo tempo homogêneo e diferido. 
são dimensões, que são mundos, deslizo sobre esses 'elementos' e eis-me no mundo, deslizo do 'subjetivo' para o Ser" ${ }^{\text {"461 }}$. Cada percebido estruturalmente se extrapola, abre-se a horizontes e se escora em um invisível que o sustenta, remete à profundidade do Ser e à transposição do sensível. Como veremos agora, cada um deles é expressão da "carne" do mundo, ela própria transcendência, matéria interiormente trabalhada que assegura a coesão do diverso:

“(..) [Um visível é] uma espécie de estreito entre horizontes exteriores e horizontes interiores sempre abertos, algo que vem tocar docemente, fazendo ressoar, à distância, certas regiões do mundo colorido ou visível, certa diferenciação, uma modulação efêmera desse mundo, sendo, portanto, menos cor ou coisa do que diferença entre as coisas e as cores, cristalização momentânea do ser colorido ou da visibilidade. Entre as cores e os pretensos visíveis, encontra-se o tecido que os duplica, sustenta alimenta, e que não é coisa, mas possibilidade, latência e carne das coisas." ${ }^{462}$

Recusando todo positivismo - e novamente a cisão entre o Ser e o Nada - a carne das coisas é diferenciação do "mesmo", totalidade e diversidade simultâneas calcadas na reversibilidade entre o Ser e o Nada. Por meio dela, Merleau-Ponty designa essa estrutura ontológica revelada pela percepção - unidade espontânea configurada por segregação interna - confirmando que o percebido e o percipiente não se opõem como dois modos de ser incomunicáveis, que ambos partilham da mesma estrutura e se encontram

${ }^{461}$ MERLEAU-PONTY, Maurice. O Visivel e o Invisivel, São Paulo: Perspectiva, 2007, p. 202

${ }^{462}$ Idem, p. 129, 130 
sob o solo comum de um Ser que é transcendência e de uma singularidade que é "elemento": como indicado, o "sujeito" e o "objeto" são feitos da mesma "carne", configurados por uma visibilidade que unifica e difere. Fora da alternativa entre o em-si e o para-si, cada um aparece agora como diferenciação no interior de uma unidade ontológica comum: o sujeito não é mais um puro nada, pois também visível e percebido, e o mundo não é mais um puro ser, pois também aberto e reflexivo:

"O visível pode assim preencher-me e ocupar-me só porque, eu que o vejo não o vejo do fundo do nada mas do meio dele mesmo, eu, o vidente, também sou visível; o que faz o peso, a espessura, a carne de cada cor, de cada som, de cada textura tátil, do presente e do mundo, é que aquele que os apreende sente-se emergir deles por uma espécie de enrolamento ou redobramento, profundamente homogêneo em relação a eles, sendo o próprio sensível vindo a si e, em compensação, o sensível está perante seus olhos como seu duplo ou extensão de sua carne."463

Reencontramos pois um operador central no interior da ontologia de MerleauPonty: a noção de diferença, como meio-termo entre identidade e alteridade, o Ser e o nãoser puros, elemento central para uma ontologia que evita os dualismo e busca afirmar simultaneamente a autonomia da parte e a ecceidade do todo, a singularidade e a unidade como reciprocamente constitutivas uma da outra - conforme indicado ao longo de nossa Tese e explicitaremos na conclusão. Por ora, o importante é notar que, aquém do subjetivo e do objetivo, a carne do Ser se aloja na auto-diferenciação originária do sensível,

${ }^{463}$ MERLEAU-PONTY, Maurice. O Visivel e o Invisivel, São Paulo: Perspectiva, 2007, p. 113 
simultaneidade entre unidade e abertura que faz da distância articulação reflexiva, respondendo por uma relação de si a si e por uma espessura que se constituem reciprocamente. Graças à negatividade estrutural que as análises de Merleau-Ponty vêm explicitando, a carne é expressão dessa homogeneidade que se configura por transcendência e extrapolação, reversibilidade que unifica equiparando os movimentos de entrar e sair de si, garantindo a consistência do mundo - sua auto-constituição -, justamente por sua reflexividade - isto é, por sua abertura -, em uma totalidade em que se torna impossível distinguir completamente o que seria o em-si e o que seria o para-si.

Será por meio da análise do corpo que Merleau-Ponty buscará explicitar a configuração dessa "carne" do Ser, mostrando que a estrutura corporal é ela própria feita da simultaneidade e da constituição recíproca do ativo e do passivo, unitária e reflexiva. Do mesmo modo como ocorria na Fenomenologia da Percepção, em que o filósofo partia da análise do corpo para então desdobrar sua analítica ao sensível - no caso, mostrando que o "milagre expressivo" revelado no corpo opera em todo o mundo ${ }^{464}$ - também aqui ele recorre à estrutura corporal para explicitar a configuração ontológica do mundo sensível, ensinando uma reversibilidade interna que não desfaz a unidade, mas a configura, fazendo do negativo distância constitutiva do presente e do visível: “(...) carne aplicada a outra carne, o mundo não a envolve [a carne do corpo] nem é por ela envolvido. Participação, aparentamento no visível, a visão não o envolve nem é nele envolvida definitivamente (...)

${ }^{464}$ Conforme nossa pesquisa de Mestrado (MOURA, Alex de Campos. Liberdade e situação em MerleauPonty: uma perspectiva ontológica, São Paulo: Humanitas, 2010). 
há dois círculos, ou dois turbilhões, ou duas esferas concêntricas quando vivo ingenuamente e, desde que me interrogue, levemente descentrados um em relação ao outro..."465

Como vimos, enquanto unidade internamente diferenciada, o sensível sustenta a sincronicidade do percebido e do percipiente, a "harmonia pré-estabelecida" que vincula internamente os gestos e aquilo que é por eles visado, assegurando a troca contínua em que se torna impossível definir quem comanda, qual o agente e qual o objeto. É justamente essa reversibilidade do ativo e do passivo que o corpo encarna: inserido no mundo, o corpo que sente se descobre também sensível para si, suas estruturas perceptivas Ihe aparecem como elas próprias perceptíveis: explicitando o paradoxo de todo o Ser, nele será o "mesmo" que percebe e que é percebido, o vidente e o visível:

"[A carne] consiste no enovelamento do visível sobre o corpo vidente, do tangível sobre o corpo tangente, atestado sobretudo quando o corpo se vê, se toca vendo e tocando as coisas, de forma que, simultaneamente, como tangível, desce entre elas, como tangente, domina-as todas, extraindo de si próprio essa relação, e mesmo essa dupla relação, por deiscência ou fissão de sua massa. Essa concentração dos visíveis em torno de um deles, ou esta explosão da massa do meu corpo em direção a elas (...)"466

A “afinidade de princípio" entre os “opostos” própria ao sensível opera pois já na estrutura reflexiva do corpo. Quando a mão esquerda toca a direita, por exemplo, há uma espécie de cruzamento reiterado, no qual não se pode delimitar exatamente qual mão

\footnotetext{
${ }^{465}$ MERLEAU-PONTY, Maurice. O Visivel e o Invisivel, São Paulo: Perspectiva, 2007, p. 135

466 Idem, p. 141
} 
toca e qual é tocada, transição constante sem termo: quando uma delas passa à condição passiva, ela permanece na iminência de tocar, recusa-se à condição de objeto, mantém-se aberta à ação; ela própria é atividade latente, à espera de que o foco do movimento único do qual participa se desloque. Passiva em um momento, ela se preserva ativa no conjunto, reversível estruturalmente, de modo que ao invés da distinção clara e positiva das partes, o que se afirma é um único movimento que ora se concentra, ora se dilata: transição ou diferenciação que se realiza por ambas as mãos, a percepção corporal age e padece simultaneamente, permanecendo constante em sua dinâmica.

Sensível para si, o corpo testemunha essa coesão que se forma por "deiscência” interna, distensão em que se dilata e reúne; ele aparece assim como uma espécie de sensível exemplar, ou seja, como arquétipo da estrutura perceptiva geral e de sua reversibilidade. Nem objeto, pois capaz de voltar-se sobre si, e nem sujeito, pois passivo e perceptível, ele exprime a unidade internamente diferenciada proposta pela ontologia de Merleau-Ponty, movimento constante de auto-segregação. Em sua dupla dimensão, o corpo encarna a reflexividade do "mesmo", totalidade ativa que se faz passiva, percepção que se singulariza no percebido, refletindo-se a si mesma. Senciente e sensível na mesma carne, vidente-visível como afirma Merleau-Ponty, o corpo é unidade da diferença: visão de direito e diferida, expressando a estrutura ontológica da própria Visibilidade: "nele [no corpo] não há duas camadas ou duas faces, e ele não é, fundamentalmente, nem apenas coisa vista nem apenas vidente, é a Visibilidade ora errante ora reunida (...) Se o corpo é um único corpo em suas duas fases, incorpora todo o sensível 
e, graças ao mesmo movimento, incorpora-se a si mesmo num 'Sensível em si."'467

É pois a unidade originária - "Visibilidade" ou "Sensível em si" - desde o início indicada pelo filósofo, que o corpo testemunha, ser interiormente negativo, cuja articulação se faz por permanente "fissão". Passagem entre a parte e o todo, transição interna entre o agente e o agido, ele é carne sensível para si, singularidade que espontaneamente se abre a um todo (de si e daquilo que the aparece), narcisismo e descompressão simultâneos. Sua unidade diacrítica ${ }^{468}$ confirma assim a estrutura única e cambiável da qual emergem tanto o vidente quanto os visíveis - tanto o ativo quanto o passivo -, dinâmica comum que ora se dilata e ora se reúne; espécie de Visibilidade ou de Tangibilidade "em si", que, como o Wesen descrito acima, "age" em cada uma de suas manifestações e nelas se reflete.

Assim, como dois espelhos dispostos um diante de outro operando uma reflexão infinita (sem termos claramente discerníveis) ${ }^{469}$, o Ser sensível se confirma como movimento permanente de voltar-se sobre si e diferenciar-se, estruturado pela distância interna que impede a identidade e instaura o "jogo" de reflexos, diferença e transcendência intrínsecas ao todo. Como ocorria desde a análise da linguagem e, de certo modo, da percepção $^{470}$, trata-se do reconhecimento desse "sistema diacrítico" que recusa a ruptura entre o ativo e o passivo. Enquanto visível, o corpo revela um percebido sempre 467 Idem, p. 134

${ }^{468}$ Como indicado nos capítulos anteriores, já na análise da linguagem e da pintura, Merleau-Ponty aproximava a diacronia da linguagem com a percepção e com o corpo, relacionando-os em sua dimensão auto-formativa estruturada pela relação intrínseca de seus elementos.

469 MERLEAU-PONTY, Maurice. O Visivel e o Invisível, São Paulo: Perspectiva, 2007, p. 135

${ }^{470}$ Como indicado nos capítulos anteriores e em nossa pesquisa de Mestrado (MOURA, Alex de Campos. Liberdade e situação em Merleau-Ponty: uma perspectiva ontológica, São Paulo: Humanitas, 2010). 
transcendente, capaz de abrir-se e refletir-se; enquanto vidente, ele revela um sujeito descentrado, que apenas se encontra "fora de si". Extrapolação e irradiação do "mesmo" que põe em suspenso a alternativa entre o ser e o nada, entre o em-si e o para-si, o corpo explicita a estrutura ontológica daquilo que Merleau-Ponty denomina "carne": o trabalho da experiência sobre si mesma ${ }^{471}$, massa interiormente estruturada por uma negatividade que a impede de repousar em si, que a torna transcendência, fazendo-a imprimir sua "essência ativa" em todas as suas manifestações particulares. Instituição ${ }^{472}$ que se extrapola, se reflete e se volta para si por auto-segregação, ela não é nem uma entidade ideal e nem um objeto determinado, nem pensamento e nem matéria puros. Como a "essência aquosa" da água da piscina de que fala $O$ Olho e o Espírito, que irradia para fora de si e transmite sua estrutura por onde se propaga, ela é afirmação do "mesmo" por distanciamento de si:

“É a essa Visibilidade, a essa generalidade do Sensível em si, a esse anonimato do Eu-mesmo que há pouco chamávamos carne, e sabemos que não há nome na filosofia tradicional para designá-lo (...) A carne não é matéria, não é espírito, não é substância. Seria preciso, para designá-la, o velho termo 'elemento', no sentido em que era empregado para falar-se da água, do ar, da terra e do fogo, isto é, no sentido de uma coisa geral, meio caminho entre o indivíduo espácio-temporal e a ideia, espécie de princípio encarnado que importa um estilo de ser em todos os lugares onde se encontra uma parcela sua $(\ldots) "$

\footnotetext{
${ }^{471}$ MERLEAU-PONTY, Maurice. O Visivel e o Invisivel, São Paulo: Perspectiva, 2007, p. 138

${ }^{472}$ Conforme a noção de instituição explicitada nos capítulos anteriores.
} 
Reencontrando um dos núcleos da ontologia de Merleau-Ponty ${ }^{473}$, a carne é mediação entre indivíduo e essência, passagem espontânea que unifica a generalidade do sentido e a particularidade do concreto. Ela não é matéria, pois é espontaneamente significativa e reflexiva; ela não é espírito, pois se afasta de si, se particulariza e se dá à ver concretamente; ela não é enfim substância, pois não dispõe da positividade com a qual a filosofia clássica compunha suas categorias. Wesen que se reflete e singulariza, "essência ativa" que se faz parcialmente visível por "fissão", a carne é reversibilidade que ata a parte e o todo sem o auxílio de qualquer operação externa, unidade originária que se faz pela constituição recíproca do fato e do sentido, graças à distância e à abertura que "consagram" um termo ao outro, fazem da transição sua estrutura originária. Passagem que impossibilita tanto o repouso em si quanto a negação absoluta, tanto o ser quanto o nada puros, a carne responde pela espessura do mundo, pela reversibilidade do Ser e pelo "há" originário de todo percebido:

"Ainda mais: inauguração do onde e do quando, possibilidade e exigência do fato, numa palavra, facticidade, o que faz com que o fato seja fato. $E$ também simultaneamente, o que faz com que tenham sentido, que os fatos parcelados se disponham em torno de alguma coisa. Pois, se há carne, isto é, se a face escondida do cubo irradia em algum lugar tão bem como a que tenho sob os olhos, e coexiste com ela, e eu que vejo o cubo também participo do visível, sou vidente de alhures; se ele e eu, juntos, estamos preso num mesmo elemento - deve-se dizer do vidente ou do visível? - essa

${ }^{473}$ Conforme nossa hipótese de trabalho, indicada anteriormente. 
coesão, essa visibilidade de princípio prevalece sobre toda discordância momentânea, por uma espécie de horror ao vácuo." ${ }^{474}$

Essa citação, central para nós, explicita a dimensão ontológica da carne que estamos procurando indicar: divergindo do pensamento clássico, ela expressa essa unidade originária do Ser, expressão de uma totalidade que se faz graças à passagem estrutural entre o visível e o invisível, à presença de uma "ausência" constituinte, não-visível que compõe com o visível um todo, unificando-o. Totalidade tecida pela imbricação entre o Ser e o Nada, ela realiza a transição que faz o fato singular espontaneamente se articular a uma estrutura mais geral, a um sentido mais amplo que o contextualiza e significa. Reversibilidade sem término entre presença e ausência que articula os fatos visíveis à significação invisível, ela reencontra um dos traços principais da filosofia de MerleauPonty $^{475}$ : o movimento originário de auto-diferenciação em que se compõe um Logos orientado, um devir coeso, unidade diacrítica cujo sentido comum se forma pela abertura estrutural de seus elementos. Dinâmica unitária que se afirma ao lançar-se, se reúne dilatando-se, ela explicita essa compreensão ontológica de um Ser estruturado pelo negativo, transição ou mediação de princípio.

Desse modo, invertendo os paradigmas clássicos e as propostas negativistas do pensamento contemporâneo, é justamente o não ser estrutural - os lados “invisíveis" que configuram a "totalidade" para a qual minha percepção se abre, por exemplo - que assegura a ecceidade Ser, essa unidade ou essa coesão que prevalecem sobre toda

${ }^{474}$ MERLEAU-PONTY, Maurice. O Visivel e o Invisivel, São Paulo: Perspectiva, 2007, p. 136

${ }^{475}$ Conforme indicado nos capítulos anteriores. 
ilusão, toda ruptura parcial. É o negativo que unifica, o movimento interno de transcendência que garante haver "algo": a unidade de seu próprio fluir. Articulando o parcial ao geral, o singular à dimensionalidade, ele garante a coesão, a unidade por horizontes que impede haver algo absolutamente idêntico (que destruiria a singularidade) ou inteiramente diverso (que destruiria a unidade), afirmando um Logos originário incabível dentro dos moldes deterministas, pois há criação, e subjetivistas, pois há continuidade intrínseca. "Horror ao vácuo", o Nada é agora a garantia do Ser:

"[A carne] esta relação mágica, este pacto entre elas e mim, pelo qual thes empresto meu corpo a fim de que neles possam inscrever e dar-me, à semelhança delas, esta prega, esta cavidade central do visível que é minha visão, do palpador e do palpado, formam um sistema perfeitamente ligado no qual me baseio, definem uma visão em geral e um estilo constante da visibilidade de que não poderei desfazer-me, ainda que tal visão particular se revele ilusória, pois fico certo, então, de que, olhando melhor, teria tido a verdadeira visão, e que em todo caso, aquela ou outra, sempre existe uma. A carne (a do mundo ou a minha) não é contingência, caos, mas textura que regressa a si e convém a si mesma." ${ }^{476}$

Contra as filosofias da identidade, em sua afirmação de um Ser absolutamente positivo, e contra as filosofias do negativo, em sua correlata suposição de um Nada absoluto, a ontologia de Merleau-Ponty propõe enfim a unidade primária do Ser e

${ }^{476}$ MERLEAU-PONTY, Maurice. O Visivel e o Invisivel, São Paulo: Perspectiva, 2007, p. 141, 142 
do Nada, um tipo de Ser que se faz pela presença de um negativo estrutural que garante sua coesão, que responde pela compossibilidade primária que incorpora toda mudança e diferença, fazendo delas sentido e unidade. Negatividade encarregada de fazer ser, de torna visível, ela é dimensionalidade operante que por fissão se particulariza, Wesen geral que "age" e transcende fazendo-se singularidade concreta: o negativo é agora gênese espontânea e ininterrupta, criação e coesão reversíveis, tecidas na impossibilidade comum de repousar em si e de romper consigo, diferença instaurada por um Nado encarregada de articular o diverso e fazer ser: "É este negativo fecundo, instituído pela carne, por sua deiscência - o negativo, o nada, é o desdobrado, as duas faces do corpo, o interior e o exterior articulados um no outro - O nada é antes a diferença dos idênticos (...) O único 'local' onde o negativo pode existir verdadeiramente, é a dobra, a aplicação um ao outro do interior e do exterior, o ponto de virada." 477

Se a percepção encontra um mundo que se oferece em sua evidência e irredutibilidade, se o sujeito não é mais constituinte, mas dilatação e descentramento, é porque antes de mais nada ela é abertura à transcendência intrínseca ao Ser, à negatividade que o institui, unifica, assegurando o "há algo" e sua reflexividade. Por sob aquilo que aparece, na ecceidade de todo percebido, há uma in-visibilidade latente e operante, que sustenta o particular, articula-o ao todo e o ancora em seus horizontes. Ao falar em visível e visível, ao construir uma terminologia que não opera mais com o dualismo clássico, mas com diferenças reversíveis - a Visibilidade ora latente ora manifesta -, é

${ }^{477}$ Idem, p. 236, 237 
justamente a unidade ontológica defendida por sua filosofia que Merleau-Ponty busca explicitar. Reencontrando nossa hipótese de pesquisa, também aqui trata-se do reconhecimento de uma gênese espontânea intrínseca ao Ser, movimento de autoconstituição calcado na reversibilidade primária do ser e do não-ser, aquém da alternativa clássica do naturante e do naturado, vir-a-ser genético e estrutural que recusa o dualismo clássico e o modelo de constituição externa por ele suposto:

"O que chamamos carne, essa massa interiormente trabalhada, não tem, portanto, nome em filosofia alguma. Meio formador do objeto e do sujeito, não é o átomo do ser, o em si duro que reside num lugar e num momento únicos (...). É preciso pensar a carne, não a partir das substâncias, corpo e espírito, pois seria então a união dos contraditórios, mas, dizíamos, como elemento, emblema concreto de uma maneira de ser geral." ${ }^{478}$

Significação encarnada, emblema concreto de uma maneira de ser geral, a carne traz ao primeiro plano aquilo que as diversas proposições de Merleau-Ponty buscam explicitar, reencontra a reversibilidade e a abertura como dimensões constitutivas. Afastando-se da noção de espírito e de corpo como entidades positivas e opostas, ela reencontra enfim a unidade originária e a reconfiguração do sentido do Nada características da ontologia de Merleau-Ponty ${ }^{479}$, compreendidas não mais como recusa mas como dimensão formativa do Ser, negativo que não nadifica, mas institui espontaneamente, fazendo Ser. Reencontra, enfim, nossa hipótese de trabalho sobre a presença de um eixo

\footnotetext{
478 Idem, p. 138

479 Segundo nossa hipótese de trabalho.
} 
constante ao longo da obra de Merleau-Ponty, apoiado em uma reconfiguração ontológica que busca explicitar a articulação interna entre o Ser e o Nada, unidade espontânea que se auto-institui continuamente por negação interna, Ser que se faz por sua negatividade intrínseca e genética. 


\section{Conclusão}

Ao longo de nossa pesquisa, tivemos oportunidade de acompanhar o modo pelo qual Merleau-Ponty empreende seu projeto de reconfiguração ontológica. Retomando uma hipótose de trabalho que havíamos circunscrito anteriormente ${ }^{480}$, e que buscava explicitar a presença de uma ontologia já em sua análise sobre a percepção, pudemos agora mostrar que este mesmo eixo ontológico se mantém no decorrer de sua reflexão, embasando suas proposições e articulando-as sob um projeto comum, claramente estruturado e embasado.

Seguindo as diversas descrições aqui indicadas, foi possível explicitar a constância do movimento no qual o filósofo, por diferentes modos, revela a impossibilidade da manutenção do dualismo ontológico clássico, sobretudo enquanto cisão entre o subjetivo e o objetivo, a significação e o concreto. Recusando o modelo da constituição como atividade externa responsável por enformar dados em si mesmos desprovidos de valor, a concepção do sentido como pura idealidade e do objeto como constructo, sua reflexão

${ }^{480}$ Conforme nossa pesquisa de Mestrado (MOURA, Alex de Campos. Liberdade e situação em MerleauPonty: uma perspectiva ontológica, São Paulo: Humanitas, 2010). 
empenha-se em reconhecer e explicitar o movimento de gênese intrínseco ao Ser, devir espontâneo e orientado assegurado por um Logos concreto que passa ao largo das concepções clássicas.

Conforme procuramos sustentar ao longo da pesquisa, este afastamento do dualismo clássico se faz pela reconfiguração do sentido do Nada, tornado agora constituinte do Ser e garantia de sua ecceidade. Desvelando uma abertura estrutural e formativa, o negativo torna-se responsável por uma unidade cuja coesão advém de sua autosegregação, espécie de distensão interna que a impede de repousar em si e fechar-se em identidade, fazendo-a irradiar, singularizar-se sem romper-se. Operando, como vimos, uma mediação interna entre o geral e o singular, transição espontânea entre a unidade e a multiplicidade, o negativo de que fala Merleau-Ponty reconfigura uma das questões centrais da fenomenologia: a relação entre a parte e o todo, explicitando o vinculo originário que faz deles não mais que momentos diversos no interior de uma unidade comum, estruturada pela passagem orgânica e ininterrupta de um a outro.

Recusando o positivismo em suas várias formas - intelectualista, materialista e mesmo, paradoxalmente, negativista -, a ontologia aqui formulada recorre ao negativo para colocar-se em um espaço anterior à cisão entre o ser e o não-ser, operador capaz de preservar a autonomia dos termos sem afirmar sua alteridade, diferença e não ruptura. A negatividade proposta por Merleau-Ponty não é negação do Ser, mas negação no Ser, abertura e descentramento responsáveis por uma gênese que the é intrínseca, metamorfose por auto-diferenciação orientada, assegurando, em um só gesto, a unidade e 
a diversidade do todo. Ao revelar esse negativo estrutural e formativo, a ontologia merleaupontyana não apenas faz os "opostos" coexistirem, mas os revela momentos reciprocamente constituintes, figuras que se revertem unindo-se e diferindo-se. O Nada é, agora, o que faz Ser, e o Ser é agora o que se auto-segrega, transformando-se e criando: o negativo se revela abertura originária, orientada pela estrutura transitiva própria ao Ser, provendo-o da espessura que the garante ecceidade, da constância que the assegura sentido. Segundo nossa leitura, é essa unidade reversível, essa espontaneidade do Ser assegurada por um Nada que Ihe é intrínseco, que a ontologia de Merleau-Ponty busca trazer ao primeiro plano.

Assim, ao tratar da linguagem, retomando o "impensado" da linguística de Saussure, o que Merleau-Ponty busca é precisamente a inseparabilidade entre diacronia e sincronia, entre o signo e o sentido, explicitando o movimento intrínseco à linguagem graças ao qual cada signo espontaneamente se extrapola rumo a uma significação comum, transcende-se em um horizonte geral que faz do parcial apenas uma diferença ou uma modalização do todo. Mostrando essa gênese que antecede a ruptura entre o subjetivo e o objetivo, ele revela a linguagem como um "tipo de ser" cuja unidade se forma por autonegação interna, processo originário que simultaneamente se diversifica e se unifica, negatividade operante como devir e criação significativa.

Aproximando, então, a dinâmica reconhecida na linguagem à da pintura, Merleau-Ponty as reúne precisamente como expressões dessa gênese espontânea e não 
posicional, retomada do devir estrutural que reconhecem no próprio sensível. Ele pode confirmar, assim, a estruturação interna do múltiplo como dinâmica inscrita no Ser, unificação que não recusa a diversidade, mas nutre-se dela constituindo-a em sentido, desvelando o Logos operante feito pela estrutura referencial de seus elementos, entidades diacríticas que necessariamente se articulam em um todo coeso.

De modo semelhante, o estudo sobre a visão dá a Merleau-Ponty a ocasião de explicitar uma "relação de ser" que não recai em identidade ou posse, preserva a autonomia dos termos ao mesmo tempo que os revela originariamente unidos, reversíveis em uma unidade partilhada. A visão, recusando o modelo clássico da constituição subjetiva, é compreendida por ele como abertura à abertura do Ser, isto é, à auto-negação por meio da qual a própria Visibilidade se faz visível, afastando-se de si, singularizando-se, como uma espécie de matriz geracional que se dá à ver parcialmente sem abdicar de sua unidade e generalidade. "Inspiração" e "expiração" no Ser, a visão confirma assim o campo ontológico em que unidade e multiplicidade, ação e passividade, não são senão momentos diversos no interior de um todo comum.

Passando então à análise da relação entre o visível e o invisível, MerleauPonty reencontra, agora de modo mais explícito, a reversibilidade estrutural entre o Ser e o Nada, confirma a existência de uma negatividade formativa que opera como horizonte e profundidade, dando sustentação ao Ser e à espessura que o faz escapar ao modelo clássico. Essência ativa que irradia singularizando-se, dimensionalidade operante que faz ser sem abdicar de sua generalidade, a ontologia da visão traz ao primeiro plano o processo 
espontâneo de auto-diferenciação por meio do qual o Ser se institui, "carne" que extrapola e unifica em um só gesto, estruturando a unidade de horizontes cuja ecceidade provém de sua abertura.

Assim, confirmando nossa hipótese de pesquisa, de um momento a outro, da análise da linguagem à da pintura e, inflexionando-as, no estudo da visão e do próprio visível, o eixo em torno do qual gravitam as descrições do filósofo encontra-se no reconhecimento dessa gênese espontânea intrínseca ao Ser, movimento de autoconstituição que se coloca aquém da alternativa entre o naturante e o naturado. Em todas as questões trabalhadas, como linha condutora e horizonte constante de suas formulações, reencontra-se essa compreensão do Ser como negatividade estruturada, devir orientado cuja unidade se faz pela constância de sua abertura e de sua transitoriedade. Matriz de toda configuração significativa, ele revela a reversibilidade entre os termos que a Tradição afirmava cindidos, "embaralha" as categorias do pensamento clássico e põe em suspenso a compreensão do sensível e da subjetividade, tal qual entendidos até então.

Explicitando um campo novo, Merleau-Ponty mostra que o originário de que a filosofia deve agora se ocupar, não é nem a ordem do inteiramente objetivo, do ser puro pois há criação e abertura - e nem do inteiramente subjetivo, do não-ser puro - pois há transição intrínseca aos elementos e constância estrutural - , e sim o "lugar" da mediação primária entre um e outro, responsável por "haver algo", unidade aberta que não está nem completamente dada como o em-si e nem completamente ausente como o para-si. Reafirmada por suas diferentes análises, a estruturação espontânea do Ser negativo 
confirma o campo anterior ao dualismo ontológico tradicional, ensina um modo de criação e uma compreensão do sentido que não excluem a existência e a facticidade, mas se fazem nelas, explicitando uma transição interna entre razão e contingência que permanece insuspeita para o pensamento clássico.

Afastando as noções de espírito e corpo como entidades opostas, recusando o positivismo da Tradição, a ontologia de Merleau-Ponty opera enfim uma espécie de dissolução das categorias clássicas, propõe uma dimensão comum em que o Ser e o Nada se revertem e se constituem reciprocamente - um Ser que não é senão a estrutura espontânea do negativo, Nada instituinte - instaurando um território novo cujas possibilidades e desdobramentos permanecem em aberto. É possível sustentar, assim, que sua ontologia - não apenas aquela de O Visível e o Invisível, mas a que se afirma ao longo de toda a obra -, embora pouco considerada pela maior parte de seus estudiosos, revela uma direção nova de sua filosofia, situa-a dentro de um debate central do pensamento contemporâneo, concernente à compreensão ontológica, e mostra a originalidade de seu projeto, ao propor a reversibilidade originária entre o Ser e o Nada. 


\section{Bibliografia}

Obras de Merleau-Ponty

MERLEAU-PONTY. M. Éloge de la Philosophie et autres Essais, Paris: Gallimard, 1997

. Humanisme et Terreur, Paris: Gallimard, 1947

.Husserl at the limits of Phenomenology, Northwestern University,

2002

. La Nature, Paris: Seuil, 1995

. La Prose du Monde, Paris: Gallimard, 1969

. La Structure du Comportement, Paris: PUF, 1967 
. Le primat de la perception, Paris: Verdier, 1996

. Le Visible et le Invisible. Paris: Gallimard, 1964

. Les Aventures de la Dialetique, Paris: Gallimard, 1955

. L'Oeil et L'Esprit, Paris: Gallimard, 1964

. L'Union de l'Âme et du Corps chez Malebranche, Biran et Bergson,

Paris: Vrin, 1968

. Merleau-Ponty à la Sorbonne. Résumés de Cours 1948-1952,

Grenoble; Cynara. 1988

Notes de Cours sur l'Origine de la Géometrie de Husserl, Paris:

PUF, 1998

. Parcous, Lagrasse: Verdier, 1997

Parcous II, Lagrasse: Verdier, 2000 
. Phénoménologie de la Perception, Paris: Gallimard, 1997

Résumés de Cours. Collège de France 1952-1960, Paris: Gallimard, 1968

Sens et non Sens, Paris: Gallimard, 1997

Signes, Paris: Gallimard, 1968

Outros Autores

BARBARAS, Renaud. De l'être du phénomène. Sur l'ontologie de Merleau-Ponty, Granoble: Millon, 1991

. Le tournant de l'expérience, Paris: Vrin, 1998

BERNARD Flynn; WAYNE, J. Froman; VALLIER, Robert (eds). Merleau-Ponty and the possibilities of philosophy, New York: State University of New York, 2009 
BERNET, Rudolf. La vie du sujet - Recherches sur l'interprétation de Husserl dans la phénoménologie, Paris: Universitaires de France, 1994

BESMER, Kirk. Merleau-Ponty's Phenomenology, London: continuum, 2007

BIMBENET, Etienne. Nature et humanité, Paris: Vrin, 2004

La Structure du comportement, Chap. III - L'ordre humain, Paris:

Ellipses, 2000

BONAN, Ronald. L'institution intersubjective comme poétique générale v. 1, L'Harmattan, 2001

L'institution intersubjective comme poétique générale v. 2, L'Harmattan,

2001

Merleau-Ponty de la perception à l'action, Université de Provence, 2005

CARBONE, Mauro. Al Confini dell'esprimible. Merleau-Ponty a partire da Cézanne e da

Proust, Milano: Edizioni Angelo Guerini, 1990 
Il sensible e l'excedente. Mondo estetico, arte, pensiero, Milano:

Edizioni Angelo Guerini, 1996

CHAUÍ, Marilena de Souza. Janela da alma, Espelho do mundo. In: O olhar, São Paulo:

Companhia das Letras, 1999

Experiência do pensamento, São Paulo: Martins Fontes, 2002

. Cultura e democracia: o discurso competente e outras falas,

São Paulo: ed. Moderna, 1980

DAIGLE, Christine; GOLOMB, Jacob. (eds). Beauvoir \& Sartre: the riddle of influence, Indiana University Press, 2009

DASTUR, Françoise. chair et langage, Paris: encre marine, 2001

.dire le temps, Paris: encre marine, 2002

DAVIS, Bret W. Martin Heidegger, Durham: Acumen, 2010

DELCÒ, Alessandro. Merleau-Ponty et léxpérience de la création, PUF, 2005 
DESCARTES, R. Meditações. In: Os Pensadores, São Paulo: Abril, 1975

DILLARD-WRIGHT. Ark of the possible, Lexington Books, 2009

DILLON, M.C. Merleau-Ponty's Ontology, Northwestern University Press, 1997

DIPROSE, Rosalyn. Merleau-Ponty, key concepts, Acumen, 2008

ELLIOTT. Brian. Phenomenology and Imagination in Husserl and Heidegger, Routledge, 2005

FERRAZ, Marcus Sacrini. Fenomenologia e ontologia em Merleau-Ponty, SP: Papirus, 2009 O transcendental e o existente em Merleau-Ponty, São Paulo:

Humanitas, 2006

FLYN, Bernard; FROMAN, Wayne; Vallier, Robert (eds). Merleau-Ponty and the possibilities of philosophy, New York: State University of New York, 2009

GERAETZ, Theodore F. Vers une nouvelle philosophie transcendantale - La genèse de la 
philosophie de Merleau-Ponty jusqu'à la Phénoménologie de la perception, Haia: Martinus Nijhoff, 1971

GUTTING, Gary. French Philosophy in the Twentieth Century, Cambridge University Press, 2001

HAAR, Michel. Peinture, perception, affectivité, IN: Merleau-ponty, phénoménologie et experiences (orgs: TASSIN, Marc; RICHIR, Etienne), Grenoble, 1992

HEIDEGGER, Martin. Etre et Temps. Trad Emmanuel Martineau, Paris: Authentica, 1985

HUSSERL, Edmund. Idées directrices pour une Phénoménologie et une Philosophie Phénomélogique Pures, Paris: PUF,1998

La crise des sciences européenes et la phénoménologie transcendantale, Paris: Gallimard, 1976

LEFORT, Claude. Sur une colonne absent. Écrits autour de Merleau-Ponty, Paris: Gallimard, 1978

MADISON,G.B. The phenomenology of Merleau-Ponty, Ohio University Press, 1981 
MERCURY, Jean-Yves. Approches de Merleau-Ponty, L'Harmattan, 2001

MOURA, Alex de Campos. Liberdade e situação em Merleau-Ponty: uma perspectiva ontológica, São Paulo: Humanitas, 2010

Sobre a questão do sentido em Merleau-Ponty: introdução a

partir de uma relação com Sartre. IN: GENTIL, Hélio; CARNEIRO, Marcelo. Filosofia Francesa Contemporânea, São Paulo: Cultura Acadêmica Editora, 2009

MOURA, Carlos Alberto Ribeiro de. Racionalidade e crise. São Paulo: Discurso Editorial / Edufpr, 2001

MOUTINHO, Luiz Damon Santos. Razão e experiência em Merleau-Ponty, São Paulo: UNESP, 2006

MULDOON, Mark S. Tricks of time: Bergson, Merleau-Ponty and Ricoeur in Search of time, Self and Meaning, Duquesne University Press, 2006

NOVAES, Adauto. O Olhar, São Paulo: Companhia das Letras, 1999 
PEILLON, Vincent. La tradition de l'esprit - Itinéraire de Maurice Merleau-Ponty, Paris:

Edittions Grasset \& Fasquelle, 1994

I' epaisseur du cogito, Le Bord de L'eau, 2004

PETTIGREW, David; RAFFOUL, François (eds.). French interpretations of Heidegger, New York: State University of New York, 2008

PIERCEY, Robert. The Uses of the Past from Heidegger to Rorty, New York: Cambridge, 2009

SAINT-AUBERT. Emmanuel. Du lien des êtres aux éléments de l'être, Paris: Vrin, 2004 Le scénario cartésien, Paris: Vrin, 2005

Vers une ontologie indirecte, Paris: Vrin, 2006

SARTRE, Jean-Paul. O Ser e o Nada, Rio de Janeiro: Vozes, 1999

Que é a literatura?, São Paulo: Ática, 1993 
SCHAPIRO, Meyer. Cézanne, New York: Abrams, 2004

SCHWAYDER, David. Statement and Referent, CSLI Publicatios, 2008

SMITH, David. Husserl, London: Routledge, 2007

STEWART, Jon. The debate between Sartre and Merleau-Ponty, Northwestern University

Press, 1998

THIERRY, YVES. Du corps parlant, Le langage chez Merleau-Ponty , OUSIA, 1987

WEBBER, Jonathan. The existentialism of Jean-Paul Sartre, New York: Routledge, 2009

WEBB, David. Heidegger, Ethics and the Ontology, London: continuum, 2009 